Universidade de São Paulo

Faculdade de Educação

\title{
ARTICULAÇÕES SIMBÓLICAS: \\ uma filosofia do design sob o prisma de uma hermenêutica trágica
}

Marcos Namba Beccari

São Paulo

2015 
Universidade de São Paulo

Faculdade de Educação

\section{ARTICULAÇÕES SIMBÓLICAS: uma filosofia do design sob o prisma de uma hermenêutica trágica}

\section{Marcos Namba Beccari}

Tese de doutorado apresentada ao Programa de Pós-Graduação em Educação da Faculdade de Educação da Universidade de São Paulo, como requisito parcial para obtenção do título de Doutor em Educação.

Orientador: Rogério de Almeida 
AUTORIZO A REPRODUÇÃO E DIVULGAÇÃO TOTAL OU PARCIAL DESTE TRABALHO, POR QUALQUER MEIO CONVENCIONAL OU ELETRÔNICO, PARA FINS DE ESTUDO E PESQUISA, DESDE QUE CITADA A FONTE.

Catalogação na Publicação

Serviço de Biblioteca e Documentação

Faculdade de Educação da Universidade de São Paulo

11

B388a
Beccari, Marcos Namba

Articulações simbólicas: uma filosofia do design sob o prisma de uma hermenêutica trágica / Marcos Namba Beccari; orientação Rogério de Almeida. São Paulo: s.n., 2015.

180 p. ils. Área

Tese (Doutorado - Programa de Pós-Graduação em Educação.

de Concentração: Organização, Cultura e Educação) - - Faculdade de Educação da Universidade de São Paulo.

1. Design (Filosofia) 2. Filosofia 3. Hermenêutica 4. Simbolismo I. Almeida, Rogério de, orient. 


\section{Universidade de São Paulo}

\section{ATA DE DEFESA}

Aluno: 48134 - 8481944 - 1 / Página 1 de 1

Ata de defesa pública de Tese do(a) Senhor(a) Marcos Namba Beccari no Programa: Educação, do(a) Faculdade de Educação da Universidade de São Paulo.

Aos 11 dias do mês de setembro de 2015, no(a) sala 130 B, às 14:00 horas, realizou-se a Defesa da Tese do(a) Senhor(a) Marcos Namba Beccari, apresentada para a obtenção do título de Doutor intitulada:

"Articulações simbólicas: uma filosofia do design sob o prisma de uma hermenêutica trágica"

Após declarada aberta a sessão, o(a) Sr(a) Presidente passa a palavra ao candidato para exposição e a seguir aos examinadores para as devidas arguições que se desenvolvem nos termos regimentais. Em seguida, a Comissão Julgadora proclama o resultado:

\begin{tabular}{|c|c|c|c|}
\hline Nome dos Participantes da Banca & Função & Sigla da CPG & Resultado \\
\hline Rogério de Almeida & Presidente & FE - USP & rado \\
\hline Marcos Sidnei Pagotto-Euzebio & Titular & FE - USP & \\
\hline Louis José Pacheco de Oliveira & Titular & UNISA - Externo & Aprou do \\
\hline André Martins Vilar de Carvalho & Titular & UFRJ - Externo & mor \\
\hline Daniel Bittencourt Portugal & Titular & UERJ - Externo & APRO \\
\hline
\end{tabular}

Resultado Final: aprovecho

\section{Parecer da Comissão Julgadora *}

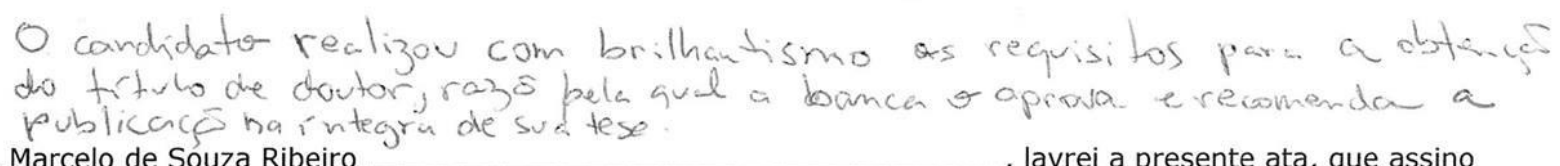
Eu, Marcelo de Souza Ribeiro , lavrei a presente ata, que assino juntamente com os(as) Senhores(as). São Paulo, aos 11 dias do mês de setembro de 2015.

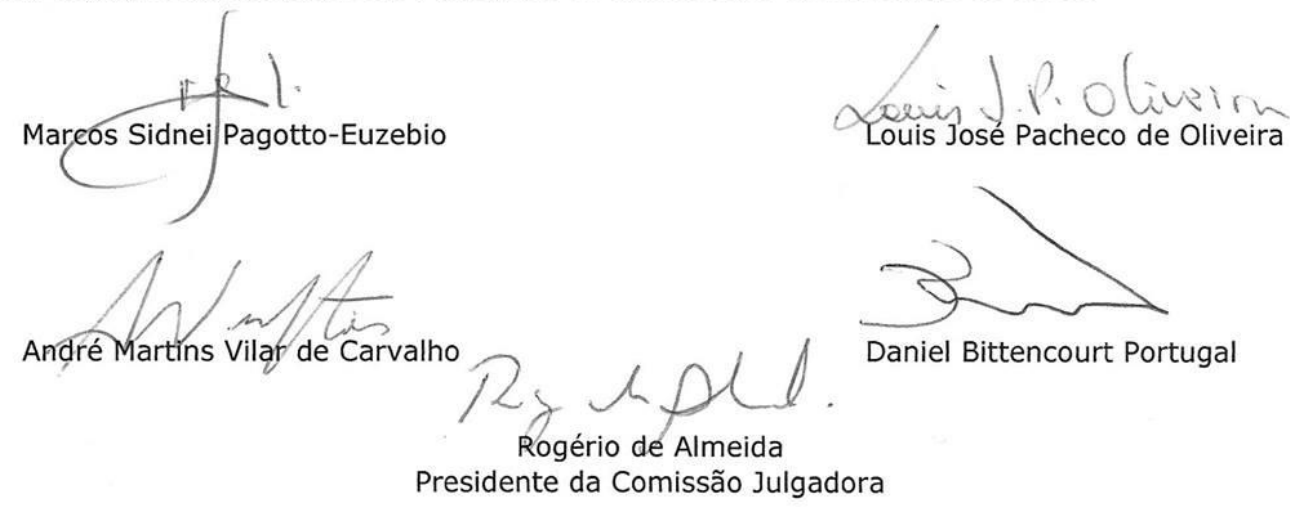

* Obs: Se o candidato for reprovado por algum dos membros, o preenchimento do parecer é obrigatório.

A defesa foi homologada pela Comissão de Pós-Graduação em e, portanto, o(a) aluno(a) faz jus ao título de Doutor em Educação obtido no Programa Educação - Área de concentração: Educação - Opção:Cultura, Organização e Educação. 


\title{
Articulações simbólicas:
}

\section{Uma filosofia do design sob o prisma de uma hermenêutica trágica}

\begin{abstract}
Resumo
O objetivo desta tese é propor um aporte teórico-filosófico — vale dizer, uma "filosofia do design" - que possa, de um lado, dimensionar a dinâmica dos processos simbólicos mediados pelo design e, de outro, situar a experiência estética articulada por esses processos. Os instrumentos de orientação utilizados foram as obras de Nietzsche, Clément Rosset, Paul Ricoeur, Rogério de Almeida e Mario Perniola, entre outros autores, além de obras literárias e cinematográficas, convocadas a ilustrar a noção de "hermenêutica trágica", inaugurada neste trabalho. Tais instrumentos foram operados metodologicamente por meio de revisão bibliográfica (modalidade básica de pesquisa), guiando-se pela hermenêutica simbólica (Ricoeur). A discussão delineada em três capítulos ("Filosofia do design", "Filosofia trágica" e "Hermenêutica trágica") visa apresentar, no quarto capítulo ("Design como articulação simbólica"), aspectos de uma articulação simbólica operada pelo design e da qual se vale o olhar contemporâneo para compreender o mundo e para nele atuar.
\end{abstract}

Palavras-chave: filosofia do design, filosofia trágica, hermenêutica trágica, articulação simbólica.

\begin{abstract}
This thesis aims to propose a theoretical and philosophical supply — that is, a "philosophy of design - which can, on the one hand, to scale the dynamics of symbolic processes mediated by design and, on the other, to place the aesthetic experience articulated by these processes. The orientation tools were the works of Nietzsche, Clément Rosset, Paul Ricoeur, Rogério de Almeida, Mario Perniola, among others, in addition to films and literary works, convened to illustrate the notion of "tragic hermeneutic", inaugurated in this thesis. These instruments were methodologically operated through literature review (basic mode of research) and guided by the symbolic hermeneutics (Ricoeur). The discussion delineated in three chapters ("Philosophy of design," "Tragic philosophy" and "Tragic hermeneutics") aims to present, in the fourth chapter ("Design as symbolic articulation"), some aspects of a symbolic articulation operated by design and by which the contemporary view takes to understand the world and to act on it.
\end{abstract}

Keywords: philosophy of design, tragic philosophy, tragic hermeneutics, symbolic articulation. 


\section{Observações para a leitura desta tese}

\section{Observação 1: Traduções}

Todas as citações de obras cujos títulos aparecem língua estrangeira nas referências foram traduzidas por mim. Sendo este o caso, omiti, na referência da citação, a indicação de que a tradução é minha.

\section{Observação 3: Aquarelas e interlúdios}

Todas as aquarelas que iniciam os capítulos são de minha autoria e foram produzidas em paralelo à escrita da tese - sendo assim, omiti nessas imagens a indicação da autoria. Também tomei a liberdade de incluir, entre cada capítulo, "interlúdios" narrativos: contos de minha autoria que servem como pontes para ligar um capítulo a outro, concernindo às questões tratadas em cada qual.

\section{Agradecimentos}

A pesquisa retratada nesta tese recebeu apoio da Coordenação de Aperfeiçoamento de Pessoal de Nível Superior (Capes) na forma de bolsa de doutorado no país. Boa parte das reflexões aqui contidas é devedora da orientação generosa e preciosa de Rogério de Almeida. O texto pôde ser aprimorado graças às sugestões refinadas oferecidas por Marcos Sidnei Pagotto-Euzebio e André Martins na banca de qualificação. Agradeço também à leitura atenta e aos comentários fecundos de Louis de Oliveira. Sou grato especialmente a Daniel B. Portugal, pela confiança e inestimável apoio que compõem nossa amizade e parceria intelectual. Agradeço, por fim, ao incondicional apoio de minha companheira, Rochele Borelli; de minha mãe, Catarina; de meu pai, Jerônimo; e de minha irmã, Carine. 


\section{SUMÁRIO}

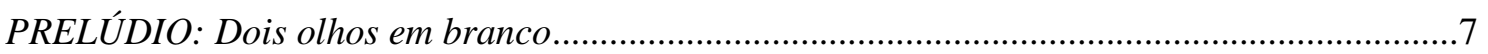

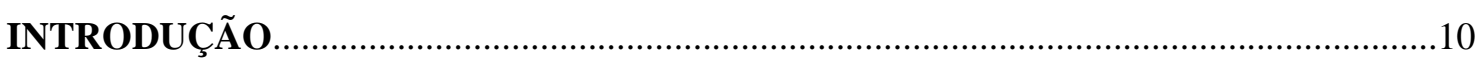

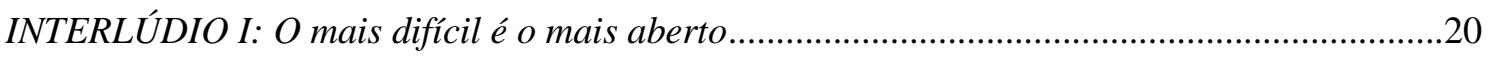

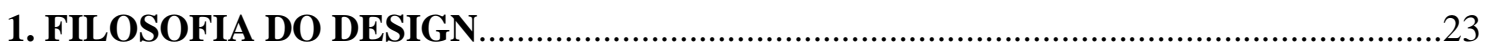

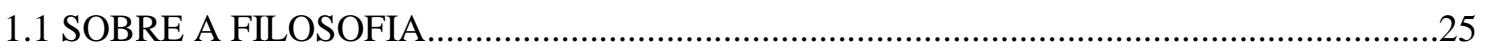

1.2 CINCO EIXOS PARA UMA FILOSOFIA DO DESIGN........................................................

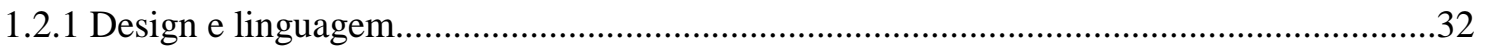

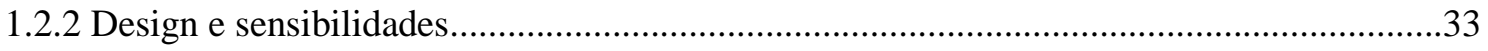

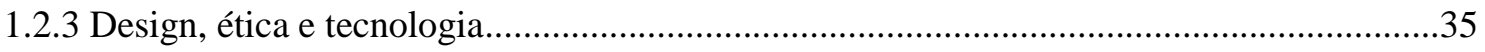

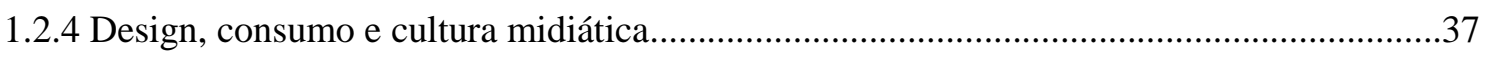

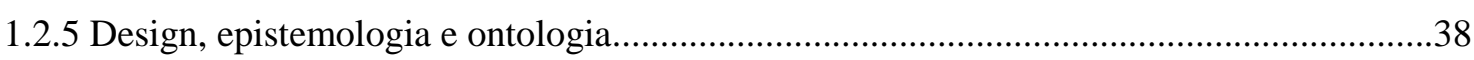

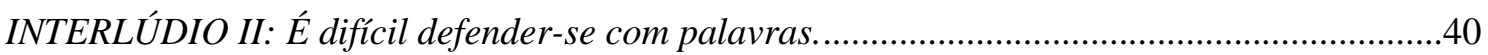



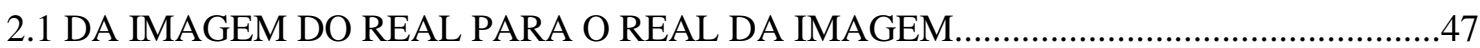

2.2 DEFINIÇÃO PROVISÓRIA SOBRE O REAL: tudo, acaso e convenção............................59

2.3 DEFINIÇÃO PROVISÓRIA SOBRE O IMAGINÁRIO: nada, convenção e ficção.............65

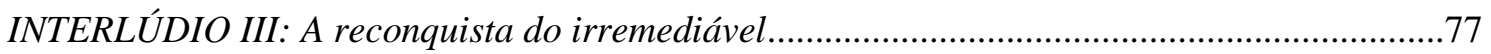

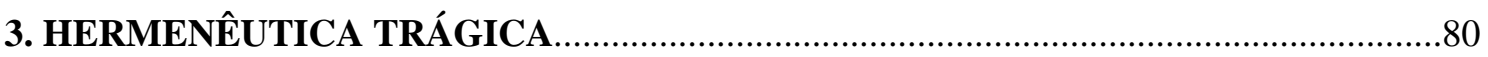

3.1 DA TEORIA DA INTERPRETAÇÃO À HERMENÊUTICA SIMBÓLICA........................82

3.2 HERMENÊUTICA TRÁGICA: símbolo, ficção e criação estética........................................99

3.2.1 Análise de Mr. Nobody: a ficção em função do acaso......................................................113

3.2.2 Análise de Em busca do tempo perdido: a redescoberta do descontínuo...........................117

3.2.4 Análise de Synecdoche, New York: a morte como ficção da vida......................................121

INTERLÚDIO IV: Daquilo que, quando você para de acreditar, não desaparece .....................131

4. DESIGN COMO ARTICULAÇÃO SIMBÓLICA...........................................................134

4.1 ENTRE ARTE E DESIGN, UM RITUAL DO MESMO PARA O MESMO......................147

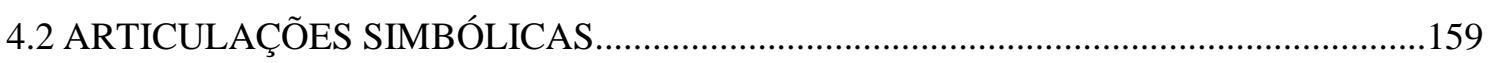

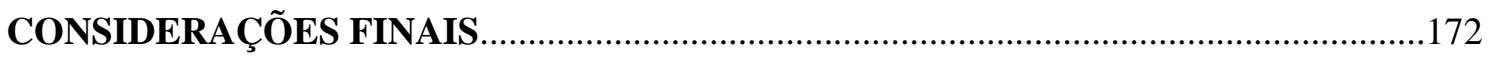

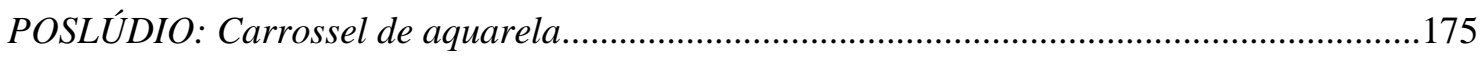

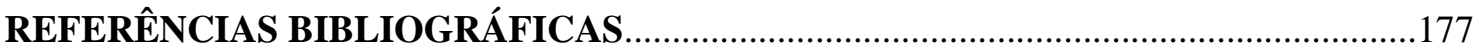




\section{PRELÚDIO: Dois olhos em branco}

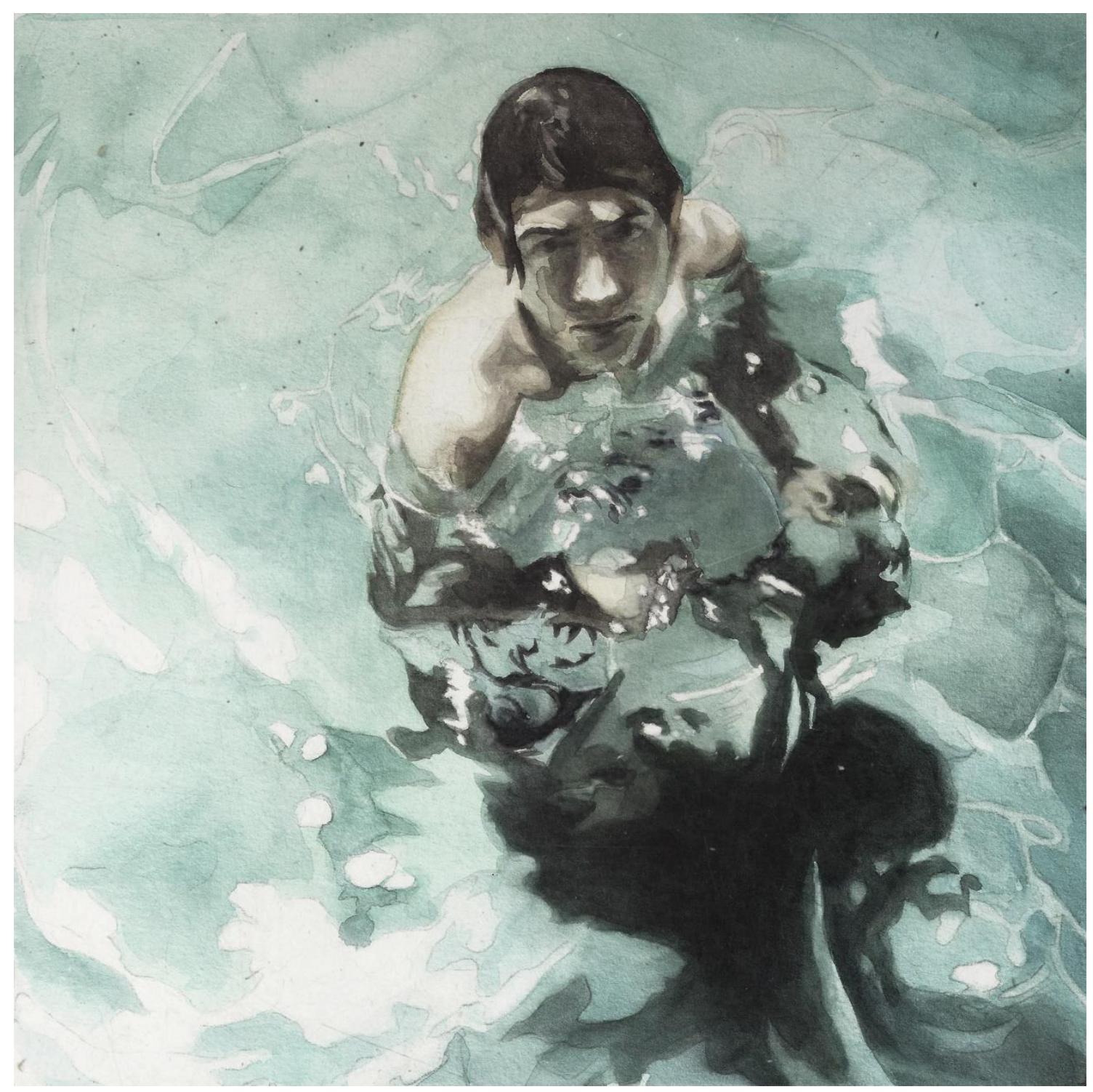

$E u$, que estou no mundo, de quem aprenderia o que é estar no mundo se não de mim mesmo, $e$ como poderia dizer que estou no mundo se não o soubesse?

- Merleau-Ponty, O visível e o invisivel.

No começo é difícil, depois você se acostuma. Não deixa de ser difícil. Talvez não seja uma questão de dificuldade, é que o imprevisto só se cria neste amontoado de dias que se repetem: cada dia que é outro em relação a si mesmo. Por isso você acorda novamente com os vultos que saem dos bueiros ou das bocas bocejantes. Porta o guarda-chuva e se lança ao trabalho. Olhos grudados no chão ou no carro que freia na 
frente. Fileiras que rezam a missa dos semáforos, vagões lotados por aqueles que miram o fim do túnel. Corre sem pressa e nem se dá conta do que manchou de roxo a sua perna. Lembra-se de fazer tudo devagar, com muita calma. Após usar o banheiro, você aperta o interruptor de luz e, por alguns segundos, espera que isso acione a descarga. Será preciso apertar novamente para manter-se acordado? Daquilo que seus olhos querem prever eles ainda conseguem se lembrar?

A chuva é tão densa quanto o cheiro de café e pão fresco que preenche o ar. Em meio aos passos em sincronia, qualquer fingimento é melhor que as convicções desgastadas. Adormecer novamente os demônios e resolver logo as pequenas coisas, até porque as grandes continuarão encalhadas no travesseiro. Entregar-se ao dia com a docilidade do sorriso alucinado da moça cega que faz o café. Dois olhos em branco num rosto erguido para o nada. Sorte que ela é bem concentrada. Assim como você, que nunca se distrai com estas coisas. A não ser com o jeito desengonçado com o qual se concentra nela agora. Porque é preciso concentrar-se para não se distrair. Agora você pensa em algo e daqui a pouco acrescenta outra coisa, e logo outra, sem que exista relação alguma entre tantas distrações que o mantêm acordado.

Disciplinadamente ao acaso, lembra-se de como a dentista ensinava a escovar os dentes: devagar, girando e voltando. Terminar apenas quando cansar. Sorrir dá trabalho, mesmo para quem possui senso de humor. A não ser para a moça-do-café, que continua a sorrir por saber que qualquer pessoa serve quando se trata de sorrir. Mas especialmente para você, que só chega cedo porque tem preguiça de fazer café em casa. É preciso conferir as notificações ainda pendentes no celular, os diálogos interrompidos, as reações indiferentes dos sorrisos sem-nome. Nomes que se sobrepõem e logo desaparecem. Curioso é como a moça-do-café ainda sabe o seu nome.

E por um momento parece que ela olha para você lá de trás do balcão. Como se perguntasse qual é a fronteira atrás da qual um rosto deixa de ser reconhecível. Ou durante quanto tempo um nome que se distancia na doença ou no esquecimento continua sendo pronunciável. Você responde, em silêncio, que a memória tem menos a ver com o que não se pode mudar e mais com a precisão de cada sentido que se altera a partir disso. Pois a mancha de café no avental da moça nunca é a mesma mancha: a cegueira da mancha é sua total incapacidade de manchar do mesmo modo. Não há mancha alguma antes da coisa manchada, antes do olhar distraído que não a anteviu, mas que continua a manchar o que não mais enxerga. 
Ela sorri novamente, para ninguém, como que em secreta complacência — "sei que você está aí, olhando para mim”. Então é como se você pudesse olhar de frente para trás, do ponto de vista do que ainda não aconteceu: começa a pensar numa sucessão de falsas lembranças, em detalhes nunca percebidos, sem haver o menor resquício do rumo que as coisas tomaram. Será possível descobrir que vivemos alguma parcela não vivida, desconhecida, coisas que aconteceram como se não tivessem acontecido? Confusa esta evidência em que você passa a se concentrar: o mundo agora está vazio, sem rostos nem sorrisos, apenas vozes e ruídos. O seu apartamento, as ruas, o escritório, tudo continua ali, como antes, com a presença de todos aqueles que de repente desapareceram, mas que ainda ali permanecem.

No começo é difícil, depois você se acostuma. Não deixa de ser difícil. Você continua às cegas, sem cura possível a não ser a das próprias lembranças, procurando nelas um sorriso que ninguém mais vê. Se você conseguisse se concentrar o suficiente poderia compartilhar esta distração que o mantém concentrado. Uma desatenção mais atenta aos detalhes, ao asfalto, aos prédios, ao céu que se esconde nas nuvens. Você pensa nas inúmeras gerações que passaram e que não estão mais por aqui, e compreende que tudo isso é esquecimento, nada mais que esquecimento, que chegará ao absoluto assim que você também aqui não estiver. Felizmente, antes disso será preciso pagar o café, recobrado na reversibilidade do acontecido, que só veio a acontecer da mesma forma irreversível como poderia não ter vindo.

É o que dizem: o que realmente acontece, acontece em silêncio. Mas não se distraia, é preciso não acreditar em demasia no sorriso daquela moça. Sorriso duplo que leva diretamente daquilo que não se consegue enxergar àquilo que inevitavelmente se vê, que é o mesmo. Por mais que a história de alguém não se confunda com a de outrem, todas coincidem com um mesmo interruptor que nunca aciona a descarga.

A moça-do-café continua sorrindo como uma palavra não dita. E você sorri de volta, sem mais a pretensão de supor que ela ainda não sabe. 


\section{INTRODUÇÃO}

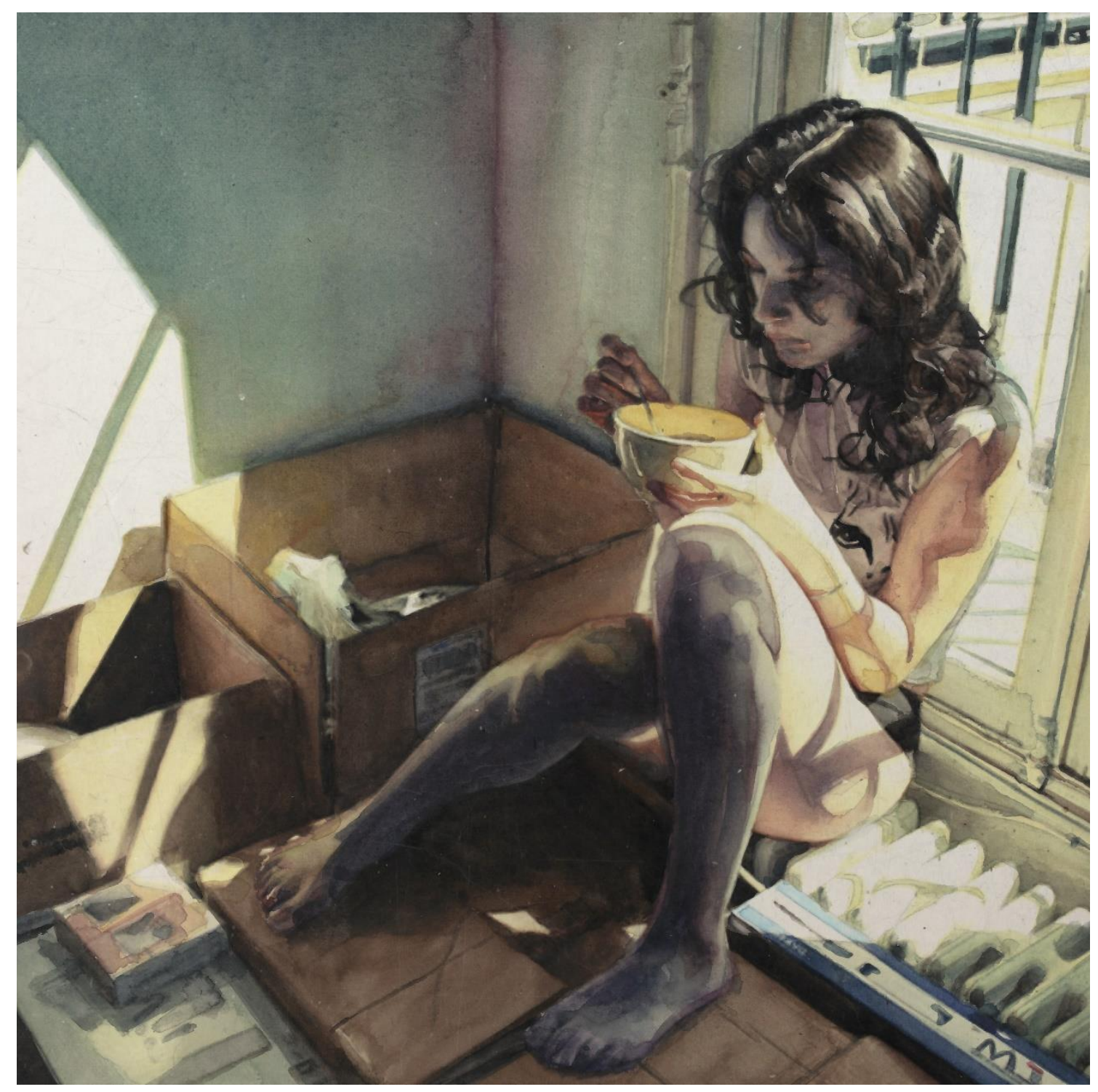

A espantosa realidade das cousas é a minha descoberta de todos os dias. Cada cousa é o que é, [...] porque cada cousa que há é uma maneira de dizer isto.

- Alberto Caeiro [Fernando Pessoa].

A tarefa do design impõe-nos um grande desafio: expressar ideias e afetos, de maneira simultaneamente visual e narrativa, mediante uma pluralidade de interpretações possíveis. Desafio que se torna mais difícil quando se procura restringir tal pluralidade interpretativa em proveito de alguma unidade de significado, geralmente atrelada à dimensão funcional da solução de um problema qualquer. A instauração de métodos e abordagens que tiveram êxito nas engenharias e outros domínios do "projeto" - 
capacidade de responder à desordem do mundo em nome de uma intenção que se considera profundamente séria e necessária - não me parece eficaz para precisar esta tarefa de expressão visual e narrativa implicada no e pelo design. O objetivo deste trabalho é propor um aporte teórico-filosófico que possa fornecer, de um lado, maior precisão na lida com os processos mediados pelo design e, de outro, uma abertura estético-educacional a partir desses processos, por meio dos quais interpretamos e articulamos continuamente uma existência finita e socialmente partilhada.

É necessário pontuar o quanto antes que "design” é aqui entendido de maneira abrangente, isto é, para além de uma atividade profissional. Sob um viés comunicacional, por exemplo, já não faria sentido entender design apenas como projeto, mas sim como articulação do olhar. Não literalmente com os olhos, "ver" implica relacionar afetos ao que é visto, às coisas como elas aparecem para nós. O modo como vemos imagens e objetos, o modo como vemos a nós mesmos e o modo como somos vistos articulam possibilidades de sentido que permeiam nossas performances comunicacionais. Logo, o território no qual a comunicação acontece reside no entrecruzamento de enunciados, sejam estes textuais ou imagéticos: o significado de um enunciado se altera à medida que ele mesmo altera o significado de outros enunciados. Em todo caso, é preciso haver uma mediação.

O “design” da água mineral Perrier, por exemplo, não reside na marca estampada na garrafa, nem na garrafa em si ou na água que vem dentro dela. Está numa articulação do olhar que enxerga nesse conjunto de elementos uma maneira especial de beber água (preferencialmente numa taça de cristal e não num copo de plástico), um estereótipo de quem pode bebê-la, as circunstâncias apropriadas para fazê-lo e até uma infactível procedência dessa água nos alpes suíços - mesmo que tenhamos enchido a garrafa numa torneira qualquer.

De maneira similar, não é simples substituir a chave do automóvel por botões e senhas: ainda que a chave se esconda ou que os botões estejam na chave, a chave precisa continuar fazendo alusão à "segurança", a uma imagem de "proteção". Em última análise, essa relação água-garrafa ou chave-botões é meramente convencional, tal como a possível semelhança de uma nuvem com a forma de um coelho. Só que o valor, a qualidade e a importância que damos às coisas não está simplesmente em sua apreciação estética ou em seu uso funcional, atrelados ou não à intenção, mas na mediação simbólica que portam e realizam.

Há uma dimensão simbólica que nos conecta com o mundo, um tipo de 
mediação ancestral que permanece efetivo e decisivo nos processos comunicacionais na medida em que, impedindo-nos de compreender o mundo sem nos referirmos a nós mesmos, sem sermos parte do que vemos e sentimos, confere-nos a aptidão de dar sentido ao mundo, ao que somos e ao que fazemos. Essa aptidão, todavia, não é unilateral. Um romance ou um filme, por exemplo, não se reduzem a mera distração e entretenimento, mas também não são apenas representações de um modelo de mundo. Se existe alguém que se propõe a ler ou a assistir, trata-se de uma mediação. A leitura me permite compreender-me diante da compreensão do mundo forjada nesta ou naquela narrativa, ampliando, assim, tanto a narrativa quanto minha própria leitura de mundo. Aquilo que o texto "diz" ou que seu autor queria dizer não importa tanto quanto o diálogo que se abre na mediação da leitura e que dela extrai afetos e olhares que antes não estavam ali. Conforme nos ensina o filósofo Paul Ricoeur (2008, p. 68),

Aquilo de que finalmente me aproprio [na leitura] é uma proposição de mundo. Esta proposição não se encontra atrás do texto, como uma espécie de intenção oculta, mas diante dele, como aquilo que a obra desvenda, descobre, revela. Por conseguinte, compreender é compreender-se diante do texto.

Penso que, no âmbito do design, ocorre algo semelhante. Foi nesse sentido que afirmei, no livro Existe design?, ${ }^{1}$ que "o problema da existência do design não é que design não faz sentido fora do olhar humano. O problema é que o olhar humano não faz sentido fora do design". Uma das origens etimológicas de design é "desígnio", isto é, intenção, propósito. Ocorre que toda proposição intencional (para a qual a noção de "projeto" é apenas uma dentre outras expressões) nunca se limita à mera intencionalidade. Quando um casal vestido com roupas específicas, dentro de uma igreja, pronuncia "sim" em frente a um padre, por exemplo, não é somente uma intenção (ou sua expressão verbal) que transforma um homem comum em "marido" e uma mulher comum em "esposa". ${ }^{2}$ É preciso haver mediação com determinadas convenções para que nossas intenções e propósitos sejam afirmados como partes de uma narrativa pessoal e coletiva. Neste caso, o vestido da noiva, as alianças de ouro e o buquê de flores compõem uma mediação, dentre outras possíveis, à qual recorrem os

\footnotetext{
${ }^{1}$ Beccari; Mizanzuk; Portugal, 2013, p. 39.

${ }^{2}$ Este exemplo ficou conhecido na obra de Austin (1975), intitulada How to Do Things with Words. Embora sua teoria dos "atos de fala" esteja bastante afastada do raciocínio aqui proposto, é pertinente a noção defendida por Austin, com o exemplo citado, de que os enunciados não são verdadeiros ou falsos, e sim bem ou mal sucedidos de acordo com cada ocasião.
} 
noivos para expressarem a importância que dão a certos propósitos. As superstições e os rituais dos povos ancestrais, assim como nossos projetos contemporâneos (pautados em narrativas sobre a vida, o amor, o trabalho etc.), são significações “designadas" para acontecimentos que possuem, a nossos olhos, alguma importância.

Tal enunciado pode suscitar alguma dúvida acerca da agência ou subsunção do indivíduo no plano sociocultural. A este respeito convém esclarecer que, como pontuou Gilbert Durand (1997), o trajeto antropológico ${ }^{3}$ se dá na troca incessante entre as pulsões subjetivas e as intimações objetivas: o "mundo", enquanto dado exterior (incluindo as convenções sociais e as influências culturais), pesa sempre sobre o homem e sua "vontade" (enquanto dado interior, incluindo pulsões e faculdades do intelecto), mas o homem também se impõe aos dados do mundo que o circunda, ora aderindo, ora resistindo. Não faz sentido, sob este viés, buscar uma anterioridade ou determinação entre os polos — seja do sujeito sobre o objeto, seja da natureza sobre a cultura —, pois estes estão implicados um no outro e não subsistem apartados.

\begin{abstract}
Assim, a apreensão imaginária do mundo e sua consequente organização do real ocorre por meio do trajeto antropológico, o que significa dizer que não há um sujeito em oposição a um objeto, mas uma troca incessante entre o subjetivo e o objetivo, de modo que o sujeito é tão carregado de experiências objetivas quanto a objetividade o é de olhares subjetivos. (Almeida; FerreiraSantos, 2012, p. 78).
\end{abstract}

Do mesmo modo, para além da acepção moderna do termo "projeto", ${ }^{4}$ design evoca o aspecto existencial do projectum, um exercício de fazer advir o que potencialmente já existe (significados, imagens, mediações simbólicas), ${ }^{5}$ conjugando uma interminável (re)tradução de diferentes convenções e intenções. É por meio do design, assim como por meio da literatura ou do cinema, que penetramos no reino dos sentidos e forjamos um significado para a vida — um significado sempre aberto e

\footnotetext{
${ }^{3}$ Recursividade pela qual se realiza, por meio de linguagem simbólica, a mediação entre o sujeito e o real; mediação pela qual irrompe o imaginário enquanto dimensão dos sentidos. Cf. Durand, 2010, p. 90.

${ }^{4}$ Calcada no pensamento iluminista, a ideia moderna de "projeto" refere-se a um constructo racional para a antecipação previdente e provedora de ações que possam moldar o futuro a partir de um modelo teórico pré-existente. No âmbito do design, tal concepção é recorrente no que tange à produção industrial, gestão de design, inovação corporativa, otimização de informações etc. Cf. Boutinet, 2002.

${ }^{5}$ Da perspectiva spinozista, o fenômeno da consciência, por exemplo, é externamente "projetado" em seu conteúdo, isto é, nas ideias de afecções ou imagens materiais que, por contínua reiteração, estruturam o repositório de representações dentre as quais sobressai, como ponto comum de referência, a imagem de autoidentificação do sujeito. Do mesmo modo, as representações que os indivíduos fazem espontaneamente de suas ações, no tecido da existência política, passam a lhes parecer projeções dessas ações. Cf. Spinoza, 2007, parte II, proposições 12-23.
} 
provisório, convém sublinhar, pois a leitura e a tradução operadas pelo design são do registro das aparências, das imagens e das superfícies.

Um designer não trabalha com configurações lineares, como textos literários ou enredos cinematográficos, mas nem por isso deixa de forjar narrativas diversas: assim como uma máscara tribal sustentava as narrativas de um clã totêmico, uma marca de sapatos ou uma motocicleta Harley-Davidson podem compor a narrativa que alguém ou determinado grupo constrói sobre si mesmo. Ou seja, por meio de analogias potenciais, um produto ou uma peça gráfica instauram mediações no limite dos "textos", lá onde nossa leitura de mundo dialoga com tantas outras — é como se imagens e objetos funcionassem como "interruptores do entendimento", em que o sentido emerge através das formas e não propriamente dos conteúdos.

O ponto que eu gostaria de destacar é que, seja por meio de "efemeridades" ou de "projetos ideais", o design constitui um espaço de significação e narrativa de quem somos — sob a mediação de condutas, "estilos de vida", valores e discursos — em relação a uma existência socialmente partilhada. Ainda que não se trate de um modo tradicional de narrativa - que teria, segundo Benjamin, ${ }^{6}$ se perdido na modernidade e sim de uma nova forma, "volátil e efêmera", de narração (Almeida, 2015a, p. 151), trata-se de assimilação e tradução de formas que informam, formam e reformulam experiências, vividas ou imaginadas, de existir no mundo.

E se considerarmos que, cada vez mais, praticamente tudo pode ser associado a "design" - partes do corpo, comidas, cidades, modelos de negócios, além, é claro, de ambientes, roupas, marcas etc. —, não será difícil compreender como uma "filosofia do design" adquire relevância não apenas aos designers, mas a todos que convivem diariamente com as propostas elaboradas por designers. De maneira esquemática, poderíamos pensar que, há algumas décadas, a visão predominante nas escolas e centros de design baseava-se num discurso funcionalista segundo o qual a forma das coisas deveria ser subordinada a uma função previamente dada: uma cadeira deve ser projetada para servir de assento; um carro, para se locomover; um cartaz, para comunicar claramente uma mensagem etc. Por outro lado, numa conferência de 2008, intitulada Um Prometeu cauteloso, o filósofo Bruno Latour (2014) argumenta que essa visão está desmoronando ou se dissolvendo em meio a outras tantas. Tal dissolução permite, conforme assinalou Daniel B. Portugal (2013), que encaremos nossas relações com os

\footnotetext{
${ }^{6}$ Refiro-me ao texto $O$ narrador: considerações sobre a obra de Nikolai Leskov, no qual Benjamin (1994) versa sobre o silêncio dos soldados que retornaram da guerra sem ter experiências para partilhar.
} 
objetos e imagens - bem como conosco mesmos e com os outros por meio dos objetos e imagens - de um modo não mais pautado por referenciais totalizantes (como função, utilidade, necessidade, propósito etc.).

O que o design tem trazido ao primeiro plano nos dias de hoje é o fato de que uma relação vale pela própria relação, que a "aparência" das coisas vale pela própria aparência. Afinal, como argumenta o filósofo Peter Sloterdijk (2011), o próprio termo “design” já não consegue mais demarcar com precisão a definição de uma atividade profissional ou de um produto/serviço, pois antes diz respeito a mediações, interfaces, reconciliações e pontos de divergência entre diferentes referenciais em disputa nas controvérsias inerentes a qualquer proposta de ação sobre o mundo. É neste sentido que devemos compreender, conforme desenvolvo no primeiro capítulo desta tese, a proposta de uma "filosofia do design": não um design filosófico e nem uma filosofia designística, mas uma interpretação filosófica das configurações simbólicas (design) pelas quais uma existência partilhada adquire sentido e importância.

Propor uma filosofia do design é a motivação de meu trabalho. Entendendo por filosofia a arte de formar, de inventar, de traduzir conceitos (Deleuze; Guattari, 1992), interessa-me compreender filosoficamente a mediação do homem contemporâneo com o mundo, com o outro e consigo mesmo. Por meio dos estudos do imaginário, tenho investigado de que modo o design atua para além da experiência de "uso" em relação a um objeto ou a uma imagem. E a partir de minha atuação como pesquisador e docente, vislumbrei um caminho para uma filosofia do design por meio da proposição de uma "articulação simbólica": um constante processo de mediação e (re)criação de narrativas que se abrem a novas interpretações - processo este a que recorremos a todo instante não somente para compreender a realidade na qual nos inserimos, mas também para nos reinserirmos nela, para nela nos situarmos, para produzirmos cultura e, sobretudo, para traçarmos um itinerário de (auto)formação.

Dito de outro modo, a interpretação filosófica que atribuo ao design pauta-se na ideia de "leitura de mundo" atrelada à de "leitura do texto" conforme Ricoeur a compreende. Leitura como ação, expressão, analogia e criação, como diálogo simultâneo do leitor com a palavra e com o mundo que o circunda. Artefatos de design são, portanto, relevantes pelo que engendram em nós, pelo diálogo que estabelecemos com eles, pela leitura do mundo que fazemos não apenas ao consumi-los, mas sobretudo quando retornamos para a nossa leitura e escrita do mundo. É neste retorno que se instaura uma narrativa: ao (re)traduzir afetos, o design possibilita modos de viver 
diferentes, ainda que na imaginação, mesmo que simbolicamente. Não porque o design nos induz a seguir ou imitar determinada conduta de vida, mas porque, no embate com suas articulações simbólicas, somos incitados a (re)interpretar a nós mesmos, a recontar nossas próprias histórias, nossas próprias ficções.

A ficção, como produto e processo de cultura, é anterior à literatura, mas dependente, tanto quanto esta, das forças de criação de sentido. Não surge, portanto, como mentira ou imitação, mas é um modo de expressar o real, mesmo que um real inventado. Esse modo é a narrativa. E aqui, numa perspectiva antropológica, a narrativa se dá como simbolização, como ordenação temporal de forças, de percepções, de intuições, que se elaboram para produzir sentido, para ordenar o real, a partir do hiato, da brecha, do distanciamento que se abre entre o real percebido e o real desejado (Almeida, 2011, p. 132-133).

Para esclarecermos como esta dinâmica criadora da "ficção" — palavra que diz mais respeito a invenção do que a mentira ou falsidade - é fundamental na proposição de um design como articulação simbólica, será ainda preciso pontuar brevemente alguns pressupostos que, não obstante, conduzem-nos também ao segundo capítulo. O primeiro deles: existimos ao acaso, ou seja, não há princípio nem significado prévio que determine o que somos e o que nos cerca. ${ }^{7}$ Em segundo lugar, se não há significado, não é interpretável, mas interpretamos assim mesmo. Por quê? Ora, novamente, se não há significado, então qualquer coisa pode ter qualquer significado. ${ }^{8}$

Só que a coisa interpretada é indiferente à interpretação que fazemos dela (as coisas continuam existindo cada qual à sua maneira), de tal modo que todos os fatos e potencialidades se igualam ao responderem a uma mesma condição: serem interpretados apesar de não serem interpretáveis. ${ }^{9}$ A questão é que a interpretação (mediada pela linguagem, pelo conhecimento, pelas imagens, pelos discursos, pelo design etc.) é a única coisa que temos. O que nos leva ao terceiro capítulo: compreender a nós mesmos é compreender-nos diante de uma narrativa sobre nós mesmos, assim como

\footnotetext{
${ }^{7}$ Logo, o que somos e o mundo que nos cerca também são fruto do acaso e, portanto, como escreveu Fernando Pessoa (1981, p. 140), sob o heterônimo de Alberto Caeiro, "O único sentido íntimo das cousas é elas não terem sentido íntimo nenhum".

${ }^{8} \mathrm{O}$ que poderia culminar na proposição (nominalista ou solipsista) tão sedutora quanto totalizante de que o real não existe e, portanto, pode ser inventado. Devo assinalar que não é este o meu ponto. O fato de não haver significado inerente às coisas não implica que elas não existam.

9 Trata-se de uma "lógica do pior", nos termos de Clément Rosset (1989, p. 57): saber que "a experiência da aprovação [do real] dispensa qualquer referência", qualquer submissão a uma verdade prévia.
} 
compreender o mundo e a vida é compreender-nos diante de uma proposição narrativa sobre o mundo e a vida. "Diante" no sentido de que não há nada antes, depois, fora ou por trás da vida (e de si mesmo) a ser desvendado, descoberto ou revelado. Segue que uma "mediação criadora" não implica reduzir a existência à interpretação que fazemos dela, mas compreender que esta se alimenta daquela e a modifica.

Seguindo este raciocínio, proponho que o design desempenha o papel de mediação do real por meio da articulação simbólica - portanto, por meio de ficções narrativas. Tal enunciado deve ser lido a partir de uma perspectiva teórica ${ }^{10}$ segundo a qual a realidade é singular e não interpretável (no sentido de possuir uma verdade), mas sempre mediada por "formas simbólicas" (Cassirer, 1994), dentre as quais estão os artefatos de design. E nessa mediação, (re)conhecimento ou interpretação do real, como detalho ainda no capítulo 3, coadunam-se os artifícios do imaginário.

Diante da falta de sentido da existência (o mundo é fruto do acaso), da falta de sentido da vida (nascer e morrer são dados fortuitos e quaisquer valores são convenções) e da impossibilidade de interpretar o real em si mesmo, o ser humano não cessa de falar, de pensar, de representar, de criar imagens e de articulá-las de modo a inventar sentidos e usá-los — não cessa, enfim, de interpretar.

Para Gilbert Durand (1997), o imaginário coloca-se em movimento a partir de duas constatações primordiais: a da morte e a do tempo que passa. Com efeito, "a realidade é sua própria fantasmagoria, e a maneira apropriada de tratá-la é escrevendo um compêndio das aparências", conforme postula o filósofo Clément Rosset (2006, p. 69), que prossegue esclarecendo-nos que "o real é a única coisa do mundo a que nunca nos habituamos" (ibidem, p. 74).

Tal proposição é aqui imprescindível não só por rejeitar a oposição clássica entre aparência e realidade, mas principalmente por uni-las em oposição à ilusão de um "mundo verdadeiro", tal como proclamava Nietzsche (2006, III, §2, p. 26) no fim do século XIX: “O mundo 'aparente' é o único. O 'mundo verdadeiro' é apenas acrescentado mendazmente". O elogio de Nietzsche à aparência, portanto, coincide com o elogio ao real, pois o espaço da representação e da imaginação é precisamente o lugar onde se encontra o real. Não se trata de despojar a realidade de sua concretude, mas de

\footnotetext{
${ }^{10}$ Filosofia trágica, elencada a partir de pensadores como Lucrécio, Montaigne, Hume, Nietzsche e Clément Rosset. Cf. Almeida, 2013; Rosset, 1989, Hierro, 2001.
} 
abandonar a metafísica tradicional que opõe o mundo verdadeiro ${ }^{11}$ à irrealidade da imagem e, portanto, à experiência imediata e sensível. A ideia de "máscara", por exemplo, recorrente em alguns aforismos de Nietzsche, nunca aparece como disfarce, indício de falsidade ou situação de logro. Pelo contrário, ela se apresenta como o mais seguro indício do real, já que seu caráter fundamental é o de ser expressão e não dissimulação do real, de ser aparência como potência positiva, como imagem, e não como contraparte negativa de um suposto real que estaria por trás dela.

A partir dessa visada acerca do imaginário como combustível da realidade (e não seu reflexo, duplo ou substituto) e entendendo o design como mediação que se instaura por meio da dinâmica da ficção, a proposição de uma "articulação simbólica" como mediação criadora afirma que, grosso modo, somente podemos (re)interpretar o mundo porque não existe um mundo idealmente pronto e finalizado à nossa espera - o que temos são aparências, que podem servir tanto como fantasias que encobrem a realidade quanto como coordenadas que nela nos situam e a reorganizam. Minha tentativa é, em suma, de apresentar o design como aquilo que articula leituras e narrativas do real, de modo a intervir nele e reestruturá-lo por meio daquilo que o constitui: a aparência, a imagem (que também são os princípios da ficção, da narrativa).

O presente trabalho, ademais, é resultado de uma pesquisa financiada pela Coordenação de Aperfeiçoamento de Pessoal de Nível Superior (Capes) no período de 2014 a 2015, e condensa minhas reflexões que relacionam o design, num viés filosófico, com as implicações educacionais decorrentes da análise de sua dimensão de "articulação simbólica". O objetivo é propor uma filosofia do design com base numa "hermenêutica trágica", conforme a descrevo no capítulo 3. A estrutura deste trabalho, por sua vez, procede como um "funil": parte-se de considerações gerais para, com uma linha de raciocínio direcionadora, chegar a uma proposição específica. Sintetizemos brevemente este percurso.

No capítulo 1 (Filosofia do Design), começo por dissertar sobre a filosofia de modo geral, no intuito de localizar minha própria postura filosófica, e prossigo propondo cinco eixos para uma filosofia do design, tentando com isso explicitar a amplitude que esse tema pode vir a abranger. A partir de tal vislumbre, no capítulo 2 (Filosofia Trágica) aponto para uma direção filosófica específica, iniciando com uma digressão sobre nossas relações com o mundo e estabelecendo, em seguida, definições

\footnotetext{
11 "Abolimos o mundo verdadeiro: o que restou? O aparente, talvez?... Não! Com o mundo verdadeiro abolimos também o mundo aparente!” (Nietzsche, 2006, IV, §6, p. 32).
} 
provisórias para dois conceitos fundamentais, "real" e "imaginário", mantendo-os numa relação de complementariedade, e não de oposição ou dialética.

Em seguida, apresento no capítulo 3 (Hermenêutica Trágica) o segundo eixo teórico deste trabalho: a hermenêutica, que logo é relacionada ao pensamento trágico e "aplicada" na análise de três peças narrativas. Tendo organizado uma visada metodológica própria, no capítulo 4 (Design como Articulação Simbólica) estarei em condições de seguir adiante na proposição de uma articulação simbólica operada pelo design, mostrando seu aspecto ritual e a experiência estética por ele articulada.

De modo geral, acabo por elevar o design a um registro estético - e, portanto, filosófico - que me parece incontornável em nossa lida com o mundo. Embora neste trabalho o problema da estética seja apenas tangenciado, deixando livre o caminho para um aprofundamento futuro, sigo na direção de uma estética não limitada ao estudo da arte e do belo, mas que abrange a compreensão sensível das mediações dos homens e do mundo - conforme a desenvolve Rogério de Almeida (2015a, p. 152):

\footnotetext{
A estética, assim, deixa de ser uma experiência controlada pelas obras de arte (fruição) e passa a dominar todas as dimensões da vida mediada. É como se a vida tivesse duas esferas: a da vida imediata (dado trágico, acaso da existência) e a da vida narrada (disposição no tempo das experiências vividas/imaginadas). A primeira vida é insignificante, incontrolável e irremediavelmente instantânea, frágil e efêmera. A segunda está aberta às interpretações, transcriações e fruições próprias da hermenêutica, da arte e da estética.
}

É esta abordagem filosófico-educacional que orienta a proposição de uma filosofia do design sob o prisma de uma hermenêutica trágica, tendo a "articulação simbólica" como noção central. Tal proposta procura apontar formas de se pensar não apenas o design e as representações por ele mediadas, mas especialmente um modo de olhar contemporâneo que já privilegia, sobretudo no senso comum, uma ideia ampla de design, conforme a descrevo no quarto e último capítulo desta tese. 


\section{INTERLÚDIO I: O mais difícil é o mais aberto}

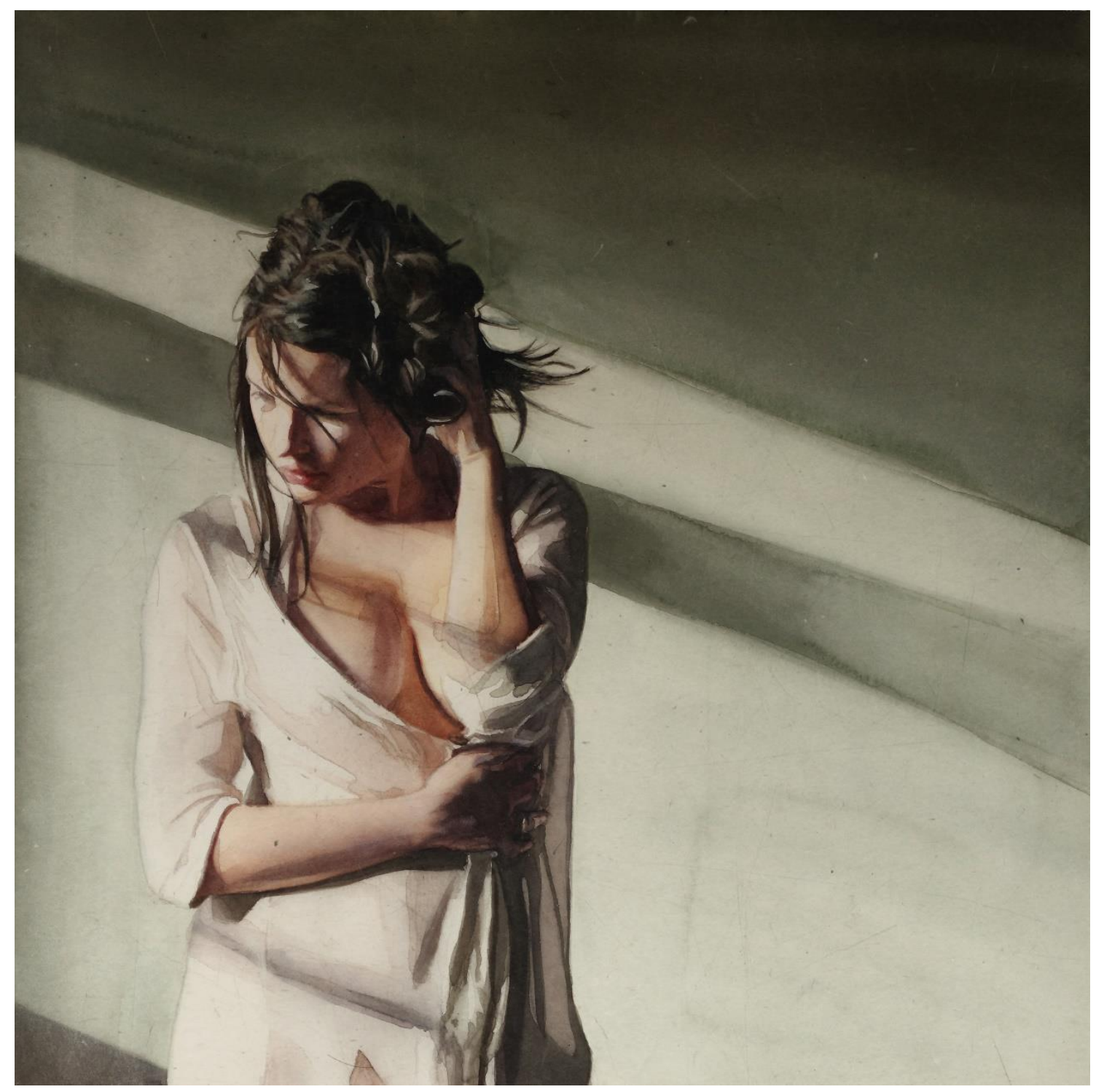

Interesses na Babilônia viram nevoeiro, poços em chamas tiram proveito. Passa, passa, passa, passa, passa, passageiro. A arte ainda se mostra primeiro.

— O Rappa, "Mar de gente"

Das aulas do professor de mitologia Marcos Ferreira-Santos que tive o privilégio assistir, gosto de recordar o "koan do chá" que certa vez ele contou para a turma: sentado em frente ao templo, um mestre ancião ensinava a seu discípulo a arte de servir o chá. "Olhe e aprenda". Primeiro chegou um rapaz jovem queixando-se de que aquele templo precisava urgentemente de reformas, pois ninguém mais entrava ali por conta 
das condições precárias do local. O velho mestre sorriu e respondeu: "É verdade! Aceita uma xícara de chá?” O rapaz bebeu, satisfeito, e foi embora.

Então apareceu uma moça que elogiou o templo, dizendo que aquele lugar era muito bonito e transmitia uma serenidade ímpar. O velho mestre sorriu e respondeu: "É verdade! Aceita uma xícara de chá?” Mais tarde, aproximou-se um senhor de idade reclamando que as novas gerações estavam perdidas, pois ninguém mais sabia dar valor à sabedoria ancestral. Novamente o mestre sorriu e respondeu: "É verdade! Aceita uma xícara de chá?" Depois que o último senhor foi embora, o jovem discípulo questionou, indignado: "Mestre, como vou saber qual é a verdade se o senhor concorda com as ideias contraditórias de todos que passam por aqui?" O velho mestre sorriu novamente e respondeu: "É verdade! Aceita uma xícara de chá?"

Se não me engano, essa anedota foi contada para ilustrar a função do professor de aprofundar o diálogo do discípulo consigo mesmo para que, deste modo, por meio da mediação do mestre, o aprendiz possa deixar de ser aprendiz. E, assim - eis o pensamento que me fez resgatar tal anedota - às vezes algum ciclo de significado se fecha e fazemos as coisas por elas mesmas, sem nenhum outro propósito além de simplesmente fazê-las. E talvez, quando chegamos ao ponto de servir o chá apenas para servir o chá, a ação ao mesmo tempo mais reflexiva e mais ativa seja a de não fazer nada além de deixar a própria interpretação em aberto. Trata-se de um tipo de aceitação que envolve a suspensão de uma nova ação, o que tanto pode alimentar vícios quanto aprofundar virtudes e perspectivas — depende do quanto conseguimos mantê-la, a interpretação, em aberto.

Digamos que o discípulo do mestre tenha se tornado, além de autodidata, um falso sofista: um pensador que se assemelha a seu mestre em todos os aspectos (armando-se com a mesma retórica e utilizando os mesmos artifícios), exceto pelo efeito contundente do imperativo "se não há verdade, então qualquer coisa serve". Ora, a afirmação "é verdade!” fazia parte da arte de servir o chá - o que, para o ex-aprendiz, não passava de um truque retórico. Só que ele nunca cogitou que a fala de seu mestre não se referia tanto à Verdade única e original quanto a qualquer uma.

Na superfície, pois, a diferença é muito pequena: o princípio de que "qualquer coisa serve" porque não há verdade ou porque, pelo contrário, tudo o que existe (que acontece ou que é pensado) pode ser verdade para alguém.

O discípulo optou pelo caminho mais fácil: suspender totalmente as verdades do mundo ao invés de manter a si mesmo em suspenso em relação às diversas 
interpretações sobre o mundo. Em suma, sua fraqueza foi a de não conseguir manter-se até o fim em aberto. Esta me parece ser a grande dificuldade de todos aqueles que, como eu, sentem prazer com o mero "conhecer": distinguir aquilo que, por muito pouco, pode deixar de ser verdade e aquilo que, exatamente por deixar de ser o que sempre nos pareceu ser, surpreende-nos em sua não-verdade.

Com isso quero dizer que ser cético ou sofista não é o mesmo que ser niilista, negador de tudo. $\mathrm{O}$ cético ainda pode ser afirmador ao sustentar que, embora nenhuma verdade exista enquanto tal, este não-reconhecimento também escapa à tentativa de dispô-lo como ideia pronta. Já para o niilista, tudo se resume a jogos de linguagem, criando para si obstáculos a um pensamento que deslize por entre tais jogos. O que, no limite, significa a diferença entre resignar-se à negação da repetição do mesmo (aceita uma xícara de chá?) ou conseguir surpreender-se com cada repetição.

Mais do que uma questão de crença, portanto, trata-se de uma questão de esforço ou desistência. Sob um olhar cético, o fácil enunciado de que "tudo depende do ponto de vista" pode implicar tanto desistência (tudo é válido porque nada é válido) quanto esforço: não importa o que se diga que “é verdade!” quando se está aberto ao encontro, fiel apenas à fugacidade das aparências que se alteram ao acaso. A verdade a ser brindada com mais uma xícara de chá consiste na afirmação de que em cada encontro que se repete teremos uma resposta diferente. Aceita uma xícara de chá? - o importante é que ainda haja uma resposta, o importante é que ainda haja diferenças. 


\section{FILOSOFIA DO DESIGN}

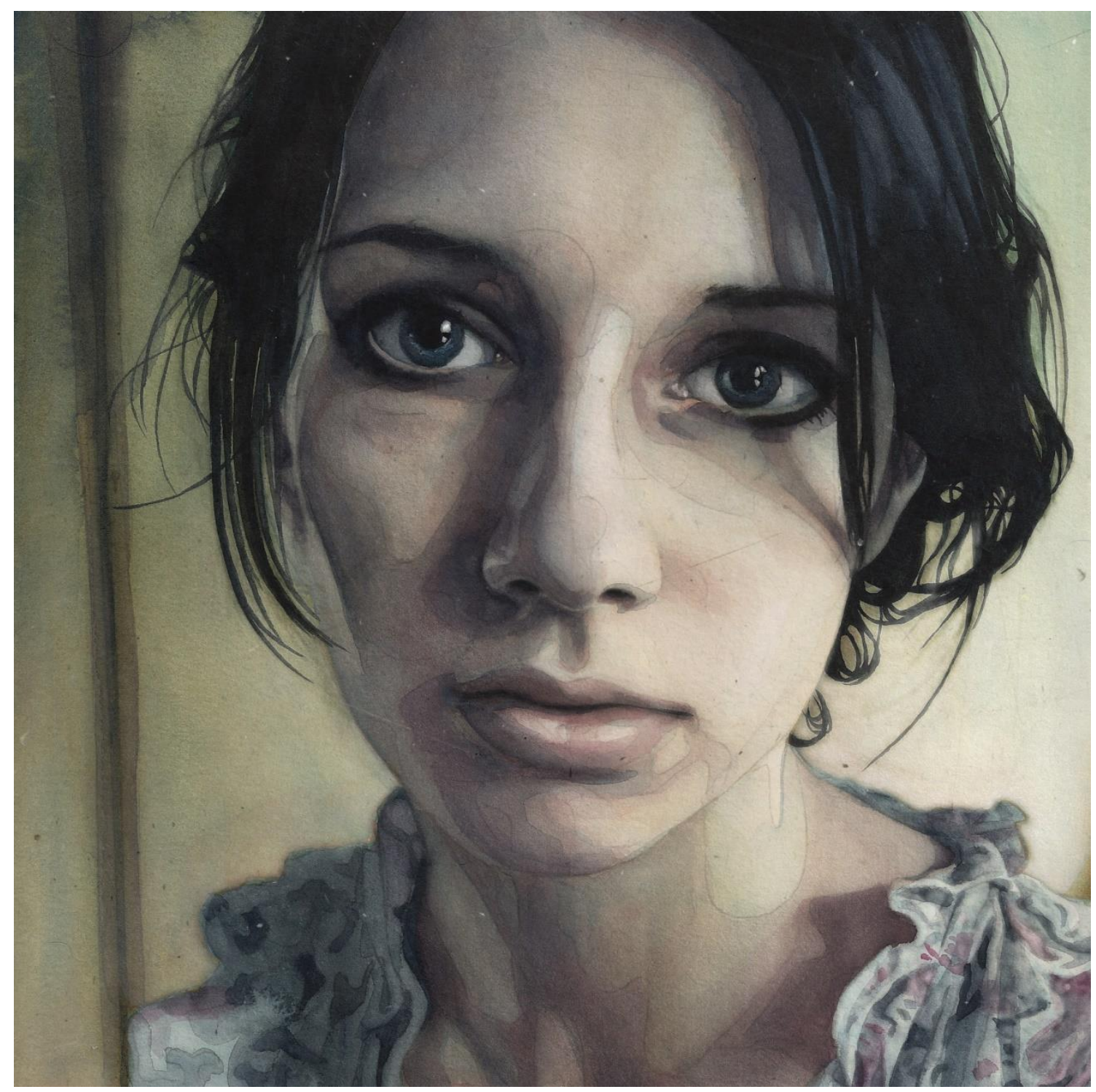

Vivemos antes de filosofar, existimos antes de o sabermos. E o primeiro fato merece ao menos a precedência e o culto.

— Alberto Caeiro [Fernando Pessoa].

Já faz algumas décadas que esforços têm sido empregados em diferentes frentes para a composição de uma filosofia do design. Alguns desses esforços provêm do campo da filosofia e de suas derivações nas ciências humanas e sociais, debruçando-se sobre questões relacionadas ao design — desde Roland Barthes, passando por Jean Baudrillard, Vilém Flusser, até Jean-Pierre Boutinet, Bruno Latour etc. Outros esforços provêm do campo do design e buscam na filosofia e nas ciências humanas e sociais 
algumas chaves para uma melhor compreensão dos problemas do design - a exemplo de Terence Love, Per Galle, Greg Bamford, Ken Friedman etc. É pertinente, neste ínterim, delinearmos um rápido panorama acerca dessas duas principais direções para, em seguida, localizarmos a proposta apresentada nesta tese. Para tanto, será preciso também esclarecer o que entendo por "filosofia" e, ainda, de que maneira uma filosofia do design poderia ser estruturada de modo a contemplar minha proposição.

No que condiz ao campo do design, a proposta mais conhecida envolve uma disciplina inicialmente desenvolvida, no fim da década de 1990, por alguns colaboradores do periódico internacional Design Studies, dentre os quais se destacam Terence Love e Per Galle. ${ }^{12}$ De modo geral, uma Philosophy of Design enquanto disciplina se ocuparia de investigar diferentes formas de pensar sobre design, tentando com isso construir um "pensar sobre pensar", teorias sobre teorias, uma metateoria do design. A partir de uma série de lacunas frequentemente elencadas na literatura acadêmica do design - sobretudo a falta de clareza sobre os fundamentos, o alcance e o limite das teorias existentes no campo - , tal proposta disciplinar procurou abranger desde a análise crítico-reflexiva dos pressupostos teóricos do design até a construção de um modelo de integração teórica para o design.

A ideia de sistematizar um "corpo teórico unificado" do design ${ }^{13}$ foi aos poucos se mostrando tão presunçosa quanto, conforme observamos em Existe design? (Beccari et. al., 2013), qualquer tentativa de determinar uma unanimidade acerca do que é design. Não é de se espantar, pois, que a proposta disciplinar de uma Philosophy of Design jamais tenha saído do papel e aparentemente tenha perdido força ao final dos anos 2000. O caminho percorrido "por fora" do design enquanto disciplina ou profissão, no entanto, tem encontrado caminhos mais profícuos.

Mas antes de avançarmos nessa direção, é preciso ainda atentar para a maneira como a filosofia tem sido entendida e aplicada nesta primeira apropriação por parte do design. Em minha pesquisa de mestrado, ${ }^{14}$ sinalizei a clara influência pós-positivista (sobretudo de Popper e Kuhn) nos enunciados dos assim chamados philosophers of design. A questão mais problemática, contudo, reside na ideia segundo a qual os designers poderiam se servir da filosofia para refletir sobre aquilo que fazem. Contra isso, é preciso esclarecer o quanto antes que, nas palavras de Deleuze (2012, p. 389),

\footnotetext{
${ }^{12}$ A este respeito, indico a leitura do relato de Galle (2002) na seção editorial da Design Studies edição 23 , que é dedicada ao tema.

${ }_{13}$ Cf. Love, 2000 e 2002.

${ }^{14}$ Cf. o capítulo "O paradigma de uma filosofia do design" (Beccari, 2012, p. 81-123).
} 
A filosofia não é feita para refletir sobre qualquer coisa. Tratando a filosofia como uma potência de "refletir sobre", tem-se o ar de lhe dar muito quando, na verdade, tira-lhe tudo. Pois ninguém tem necessidade de filosofia para refletir. [...] A ideia segundo a qual os matemáticos teriam necessidade da filosofia para refletir sobre as matemáticas é uma ideia cômica. Se a filosofia deveria servir para refletir sobre algo, ela não teria nenhuma razão de existir.

\subsection{SOBRE A FILOSOFIA}

O próprio termo "filosofia do design" geralmente é criticado em dois sentidos: de um lado, os filósofos não reconhecem na filosofia nada que possa justificar uma subdivisão desse tipo; de outro, os designers não avistam a necessidade de uma conceituação filosófica para o design. Ambos possuem toda razão. Ao menos sob o pressuposto de que a possibilidade de uma filosofia do design deveria ser relegada, de antemão, ao nível de uma "subdivisão" filosófica e de que, não obstante, o pensamento filosófico só teria aos designers um interesse secundário mediante a "prática do projeto" (essa definição quase hegemônica do design). Como já antecipei na introdução, tais premissas nada têm a ver com o que chamo de "filosofia do design". É claro que a utilização do mesmo termo pode trazer mais confusão do que elucidação, mas um urinol nunca deixou de ser urinol apenas porque alguém um dia o chamou de obra de arte. Com efeito, uma vez que a noção de "design" tenha sido de início problematizada, convém clarear agora o que neste trabalho é entendido por "filosofia".

Não é difícil de perceber a recorrência de uma acepção tradicional: atividade que, por meio de conceitos, determina ou busca (pressupondo, pois) a essência, os princípios e os fundamentos de todas as coisas. Essa definição não apenas sustenta aquele problemático encargo de "refletir sobre" (como se o pensamento reflexivo fosse privilégio da filosofia) como também, principalmente, incorre no risco de pressupor uma ordem desconhecida e autossuficiente do universo inscrita numa espécie de céu ao qual apenas certos seres iluminados poderiam ter acesso. Se levássemos a sério tal campanha, porém, estaríamos anacronicamente rivalizando com Platão, Kant, Hegel etc.

Em contrapartida, Nietzsche talvez tenha sido um dos mais conhecidos a reivindicar, ao fim do século XIX, um "martelo" como arma necessária para quebrar esses ídolos — ou melhor, para fazê-los ressoar com pequenas batidas, mostrando que 
são ocos. Os ídolos ocos em questão seriam os grandes ideais (Deus, Verdade, Razão, Bem etc.) construídos pela tradição filosófica ocidental que, segundo Nietzsche (2006), nos empareda numa visão de mundo estreita e negadora da vida. A título meramente didático, podemos resumir grosseiramente tal tradição a partir dos três cânones mencionados:

- Platão pode ser considerado o grande arquiteto da metafísica, com sua teoria de um mundo ideal, eterno e imutável. O acesso a este mundo das Ideias - à essência das "coisas", portanto (cópias imperfeitas que findam no plano terreno) - somente estaria aberto, segundo Platão, pela via da razão filosófica;

- Kant marcou o início da ruptura com a metafísica ao demonstrar como o pensamento está sempre "pressuposto" na percepção dos fenômenos. A razão humana, antes vista como virtude que abria acesso ao mundo das essências, passou a ser encarada por Kant como uma faculdade que não pode dar acesso a nada para além do homem, ou seja, ao que ele chama de "Coisa em si"; 15

- Hegel buscou alcançar uma identidade entre a coisa e seu pressuposto (o pensamento acerca dela): um Absoluto que suprimiria tal diferença ao conservá-la dialeticamente como "aparência necessária". A pretensão hegeliana, pois, é a de esperar que nosso pensamento e suas limitações nos conduzam a um saber histórico absoluto que dialeticamente os pressuponha.

É quase impossível não ter essa tradição em mente, mesmo que seja para denunciá-la com um martelo. Agora, acreditar que há algum tipo de projeto milenar em busca do "conhecimento verdadeiro" sendo operado pela filosofia ${ }^{16}$ não é algo com o qual se possa concordar ou discordar — assim como em relação à crença na vida após a morte. Eu apenas não acredito. A questão é que, para quebrar qualquer regra, é preciso haver antes alguma regra. Quando se fala em filosofia hoje, não apenas é possível negar sua definição tradicional, como também muitos filósofos já o fizeram (sem escapar, é

\footnotetext{
${ }^{15}$ Esta manobra kantiana pode ser lida, em termos foucaultianos, como uma "analítica da finitude": o sonho da cultura moderna de querer encontrar no homem o fundamento do próprio homem. É a partir desta virada antropológica que Foucault (2007) irá explorar, como em As palavras e as coisas (1966), as formas da negatividade e a finitude humanas, além das figuras que ocupam o lugar que a ausência dos deuses e dos valores absolutos deixou vazio.

${ }^{16}$ Este projeto existe, é um fato; o que eu coloco em questão é o seu enunciado: busca de um logos ontico do Real, desejo de esclarecimento que pressupõe um conhecimento verdadeiro.
} 
claro, de mencioná-la), desde Lucrécio, Montaigne, Nietzsche etc. Ao mesmo tempo, contudo, é verdade que há toda uma corrente filosófica (a dominante, diga-se de passagem) que se serve da prerrogativa tradicional do "esclarecimento" para, entre outras coisas, se erigir como arauto da grandeza humana - no caso do Brasil, vemos isso abertamente na grandiloquência do discurso de Marilena Chauí.

E nisso reside toda a pretensão e todo o engano de certas filosofias. Por exemplo, segundo Chauí, em seu famoso Convite à filosofia, uma das primeiras tarefas do filósofo seria a de abandonar o "senso comum", isto é, a ingenuidade e a ideologia que aliena as pessoas. Ora, em que medida o senso comum estaria alienado, desprovido de saber, incapaz de pensar ou lhe faltaria o saber necessário para agir e ser consciente de si? Se deixarmos o mito marxista de lado, bem como a moral kantiana acerca de um "pensamento crítico", veremos que a única coisa que talvez "falte" ao senso comum é o léxico filosófico. Mas qual é a serventia de tal vocabulário para as pessoas? Claro que ele pode lhes ajudar a compreender o mundo, mas outros léxicos também o fazem, muitas vezes de maneira mais eficaz. Enfim, nunca faltaram filósofos contrários a essa concepção "oficial” da filosofia — a exemplo de Michel Onfray em sua Contra-história da filosofia. ${ }^{17}$

Não é que essa tradição filosófica oficial não tenha a menor importância: pelo contrário, é preciso conhecê-la tanto quanto é preciso conhecer as regras oficiais das leis de trânsito - das quais eu, pelo menos, nunca tive pleno conhecimento. Quer dizer, a importância do conhecimento é que ele sirva para minha vida, e nunca o contrário. É nesse sentido que a definição atribuída por Deleuze e Guattari (1992) à filosofia me parece interessante, sobretudo por não cerceá-la com algum tipo de privilégio essencial. Eles insistem que a filosofia é uma operação mais criativa do que reflexiva. Assim como a arte, a ciência e tantas outras disciplinas que, junto à filosofia, são por esses autores colocadas num mesmo nível de "baixeza", isto é, como sendo apenas modos distintos de uma mesma dinâmica de criação e expressão humanas.

É claro que toda criação já está engajada num modo de expressão peculiar, como no caso dos "conceitos", necessários a toda criação filosófica. Entretanto, há conceitos filosóficos que podem gerar excelentes ideias para um artista, um cientista ou um cineasta. Deste modo, a preocupação deleuziana não era a de demarcar limites e fronteiras, mas a de abrir cortes transversais entre a filosofia e outros campos de

\footnotetext{
${ }^{17}$ Tratado dividido em seis volumes, sendo quatro deles publicados no Brasil pela editora WMF Martins Fontes, de 2008 a 2012.
} 
expressão criativa - o que lhe permitiu fazer filosofia tal como um artista, conjugando a objetividade conceitual com a poética afetiva das imagens.

Em todo caso, definir o que é e o que deixa de ser filosofia será sempre mera expressão conceitual (inclusive aquela suposta tarefa de acessar as essências) e, apenas neste sentido, o problema do ser, da essência e do "desconhecido" continua inseparável do campo filosófico (nem que seja para denunciar tais problemas como ilusórios). Se partirmos, por exemplo, da premissa de que qualquer coisa que seja pensável ou passível de expressão não escapa de conceitos, signos e artifícios do conhecimento, notaremos que não resta parte alguma do que chamamos de "mundo" para além disso: tudo que nos é "desconhecido" somente o é porque pode ser conhecido. Tanto que qualquer teoria filosófica, a meu ver, mesmo a mais exaustivamente sistematizada (acessível apenas a alguns "iniciados”), compõe-se de ideias simples, que boa parte de nós já teve ou poderia ter. Não me parece uma tarefa filosófica, portanto, tratar do desconhecido - ainda que, mesmo após a chamada "virada linguística", se tenha continuado a apostar para "além" dos artifícios da linguagem. ${ }^{18}$

Mais do que isso, penso que circunscrever a filosofia a uma essência ou busca por essências é subtrair sua razão de existir, que é existir sem razão, sem utilidade, como um fim em si mesmo. ${ }^{19}$ Afinal, contra a pretensa tarefa filosófica de responder qual é a essência das coisas poderíamos perguntar: mas o que a filosofia andou fazendo durante esses dois mil e tantos anos, se ainda não formulou uma resposta? Ou então, tendo respondido tantas vezes, por que continua nessa mesma busca? Pois bem, creio ser possível encarar todas as questões filosóficas (o que é a existência, o real, o homem, o mundo etc.) como variações de uma mesma questão: a de como podemos "traduzir" o mundo, a existência, o homem etc. em conhecimento. E penso que este conhecimento diz menos respeito ao mundo (só podemos "desvendar" um mundo que nós mesmos "encobrimos") e mais ao conhecimento mesmo. ${ }^{20}$

Ora, se qualquer tradução nunca traduz o mundo em si, mas outras traduções (como a que traduz o mundo por "mundo"), então as "respostas" de todas as perguntas

\footnotetext{
${ }^{18}$ Em especial no estruturalismo, por exemplo, é pressuposto que as figuras do saber e da linguagem obedeçam a uma mesma lei profunda. Cf. Deleuze, 2006, p. 221-247.

${ }^{19}$ Devo ao professor Rogério de Almeida esta compreensão "profana" da filosofia, bem sintetizada em seu provocativo texto Da inutilidade do ensino de filosofia na escola (Almeida, 2014).

${ }^{20}$ Essa afirmação não deve ser lida como algum tipo de nominalismo ou a priori epistemológico: se o conhecimento não é inerente ao mundo, tampouco o prescreve. Não significa, em contrapartida, que o conhecimento seja de segundo gênero, como se o mundo não se prestasse a ser conhecido; o conhecimento é tradução que necessariamente interage com o mundo, uma vez que o homem que conhece nunca está apartado do mundo. A este respeito, Cf. Martins, 2009.
} 
nós já temos: o mundo é o mundo, a vida é a vida, a morte é a morte. Se jamais nos contentamos com elas é porque preferimos reiniciar este mesmo processo, fazendo tantas traduções quanto formos capazes de fazer. Uma vez constatada a existência, uma vez aprovada a realidade (mesmo a mais desagradável, como a morte), todo o resto não passa de expressões, representações, mediações, relações com essa realidade. Por isso que acredito, convictamente, que todas as construções, científicas, filosóficas ou mesmo religiosas guardam uma aproximação maior do que imaginamos com o design.

Podemos definir a natureza, a verdade, a essência, a materialidade etc. do mundo, mas jamais escaparemos da tarefa de, antes, conhecê-lo e traduzi-lo de algum modo. Nesse sentido, a relação do design com a filosofia se torna mais clara: a criatividade do filósofo e a do designer (assim como a do cineasta, do artista, do cientista etc.) repagina, remoldura, reveste, dá novas formas às coisas e eventos que a todo instante traduzimos em conceitos. É claro que há uma distinção entre os modos de construir essa tradução. A questão é que hoje e sempre muitas pessoas mantêm, por exemplo, uma visão supersticiosa de mundo (não passam debaixo da escada, acreditam em horóscopo), e isso nunca as impediu de traçar "ceticamente" seus projetos de vida. Ou seja, há uma dimensão em que essas coisas não estão separadas. Mesmo a atividade do projeto não deixa de ser uma espécie de tradução — uma tradução não por analogia (como caracterizo a do design), mas ordenada e direcionada a algum propósito preestabelecido. E do mesmo modo como ocorre nas superstições, não há propósito, intenção ou finalidade que não seja imaginado pelo homem, isto é, que não passe pelas imagens, expressões e mediações que estabelecemos com o mundo e conosco mesmos.

Portanto, se encararmos o design como um modo de pensamento, de conhecimento e de ação análogo ao modo filosófico, aí sim podemos falar de uma filosofia do design conforme eu a concebo, defendo e tenho desenvolvido. A filosofia de que falo, como um fim em si mesmo, como tradução de traduções, pouco ou nada serviria a um design restrito à atividade de projeto. Mas é totalmente pertinente para tornar visível este constante processo de mediação e (re)criação de significados que se abrem, deliberadamente ou não, por meio do design. Não que esse processo esteja restrito ao design (passa também pela literatura, pela religião, pela ciência, pela própria filosofia e, enfim, pela miríade de expressões culturais). A questão é que as narrativas mediadas pelo design podem ser compreendidas como enunciados filosóficos que, ao serem interpretados, refletem e proporcionam "modos de ser" diversos.

Por isso sempre interessou aos designers, muito mais do que a própria 
teoria/história do design, todo tipo de conjugação narrativa ou filosófica. Uma vez que objetos e imagens nos sugerem condutas, "estilos de vida", valores e significados, é pertinente a uma filosofia do design investigar e dimensionar o imaginário contemporâneo, sempre se valendo de múltiplas interpretações. "Dimensionar", cumpre pontuar, no sentido de uma empreitada genealógica (nos termos de Nietzsche) ou discursiva (nos termos de Foucault), isto é, com vistas a uma rede de relações entre elementos heterogêneos (enunciados, instituições, disposições administrativas etc.) e não a uma formulação de princípios fixos. ${ }^{21}$ Logo, assim como Foucault nunca pretendeu elaborar uma teoria do poder, meu propósito não é elaborar uma teoria acerca do design, e sim trabalhar com hipóteses filosóficas sobre o funcionamento do design em relação à lida estética das pessoas consigo mesmas e com o mundo.

\subsection{CINCO EIXOS PARA UMA FILOSOFIA DO DESIGN}

Foi com o intuito de fomentar este tipo de reflexão, e não de balizá-la de maneira sistemática ou normativa, que em 2010 eu criei o site Filosofia do Design. Prezando pela multiplicidade (e não unanimidade) das diversas visadas filosóficas que poderiam, cada qual, oferecer uma tradução diferente ao design, a nós mesmos e ao mundo em que vivemos, eu e alguns colaboradores temos produzido ensaios, artigos e conteúdo multimídia (vídeos e podcasts), além de organizar cursos e grupos de estudos. Por esse caminho, na contramão da empreitada unificadora da Philosophy of Design, notamos que a vantagem de se pensar em termos de visadas ou mesmo de "constelações" - e não de bordas ou fronteiras — é justamente a de manter em destaque a tendência crescente, sobretudo no que diz respeito às disciplinas de viés humanístico, ao esfumaçamento de modelos teóricos totalizantes.

Atualmente, o site Filosofia do Design é coordenado por mim e por Daniel B. Portugal. Em parceria, criamos cinco "eixos reflexivos" para organizar a paisagem dos esforços filosóficos que, como vimos anteriormente, têm florescido amplamente "por fora" do campo do design. Estes eixos nos serão úteis, avançando no panorama aqui

\footnotetext{
${ }^{21}$ A abordagem apresentada por Foucault (1996) em sua célebre conferência A ordem do discurso pode elucidar esse ponto metodológico. Para levar a cabo sua tarefa de "devolver aos signos sua realidade de discursos", o filósofo critica três temas clássicos dos quais é preciso desviar: a ideia de um sujeito fundador (subjetivismo), a noção de uma experiência original (objetivismo) e a aposta numa mediação universal (razão dialética). Detalho no capítulo 3 uma forma de operar tais desvios.
} 
iniciado, para organizar a profusão de contribuições voltadas a uma concepção mais profícua de "filosofia do design", bem como para localizar a proposta filosófica desta tese. É preciso sublinhar, antes de tudo, que a divisão dos eixos não se pretende exaustiva. Não se trata de abranger todas as possibilidades reflexivas no âmbito de uma filosofia do design, apenas de indicar alguns caminhos possíveis de reflexão. Até porque não é a "reflexão" em si, conforme critica Deleuze, que nos interessa, mas justamente os caminhos a serem percorridos pelas reflexões. Procuramos os meios para uma expressão filosófica criativa. Interessa-nos também não demarcar logo de início uma definição fechada de design, muito menos uma finalidade específica para a filosofia. Deste modo, cada eixo encara o design a partir de um ângulo diferente, conforme a seguinte disposição:

- I. Design e linguagem: o design é visto como veículo de significado;

- II. Design e sensibilidades: o design é visto como veículo de afetos;

- III. Design, ética e tecnologia: o design é visto como suporte na lida com novas tecnologias e com as novas formas de "estar no mundo" que elas impulsionam;

- IV. Design, consumo e cultura midiática: o design é visto como elemento constituinte das culturas pautadas pela centralidade do consumo e da mídia;

- V. Design, epistemologia e ontologia: o design é visto como um modo específico de pensamento, de conhecimento e de articulação de "modos de ser".

Como qualquer categorização, o recorte dos eixos possui uma dimensão arbitrária, mas foi esboçado ao longo de nossas pesquisas sobre filosofia do design e se provou bastante proveitoso na organização das reflexões que, nos últimos cinco anos, produzimos em grupos de estudos dedicados ao tema. Ademais, o olhar de cada eixo não exclui os demais; ao contrário, a maioria das reflexões tende a se apoiar no cruzamento de dois ou mais eixos, embora na maior parte das vezes seja possível destacar um eixo principal. A seguir, faço uma descrição resumida de cada eixo no intuito de tornar visíveis os contornos de uma divisão que prioriza a superfície e as conexões topológicas, mais do que uma demarcação extenuante. 


\subsubsection{Design e linguagem}

Nesse eixo, o design é estudado em sua dimensão de veiculação de significados. Esse talvez seja, de todos, o mais fácil de delinear, porque engloba uma área de estudos já bem conhecida no campo do design: a semiótica. Como se sabe, a semiótica se desenvolveu quase simultaneamente em duas linhas: a americana, inaugurada por Peirce, e a francesa, inaugurada por Saussure com o nome de semiologia. A partir desta segunda abordagem, os estruturalistas franceses tenderam a considerar, principalmente entre as décadas de 1950 e 1970, a língua como base de articulação dos demais sistemas de significação humana.

Foi nesse período, por exemplo, que Barthes (2001) propôs uma abordagem semiológica para imagens e objetos. Jean Baudrillard levou adiante tal proposta em $O$ sistema dos objetos, sua tese de doutorado sob a orientação de Barthes. Com a intenção de analisar a estruturação discursiva que os objetos atualizam ao ser consumidos, Baudrillard argumentou que o consumo não ocorre por ocasião de uma "necessidade essencial" da sociedade, mas resulta de relações diferenciais à maneira como se constituem os signos linguísticos enquanto veículos de significado:

\footnotetext{
Sem dúvida os objetos sempre constituíram um sistema de referência, mas paralelamente e muitas vezes acessoriamente a outros sistemas (gestual, ritual, cerimonial, linguagem, estatuto de nascimento, código de valores morais etc.). O que é característico de nossa sociedade é que os outros sistemas de reconhecimento neles se assimilam progressivamente em benefício exclusivo do código do standing [prestígio social]. [...] Mesmo as condutas refratárias a tal código são consideradas em função de uma sociedade que a ele se conforma (Baudrillard, 2008, p. 202).
}

Sob esse viés, os objetos são produzidos menos para satisfazer uma necessidade ou demanda econômica e mais para sinalizar um status no interior de uma configuração social. Trata-se de uma "economia política do signo" que, em vez de pautar-se na propriedade dos meios de produção, põe em jogo um modo de produção radicalmente diferente do modo de produção material. Mais recentemente, o filósofo alemão Axel Honneth (2003) tem sublinhado a importância do plano "cotidiano" nos modos de reconhecimento, em contraposição ao que ele denomina "déficit sociológico": 
teorizações que buscam mapear estruturas de dominação.

Observemos aqui uma possível interconexão entre os eixos: o tema da relação entre homens e objetos, ainda que mediada por imagens e signos, pode reaparecer no eixo IV, no qual o design é encarado como atividade que articula mercadorias na vida social. Por sua vez, a percepção de que o sustentáculo da vida social não é a necessidade, mas a simbolização, a ritualização e mesmo, como propõe Perniola (2000), o erotismo, poderia ser retomada no eixo II, no qual o registro dos afetos aparece em primeiro plano. É importante atentarmos neste primeiro eixo para o modo abrangente com que os estruturalistas e pós-estruturalistas encaram a linguagem (que não deixa de ser uma estrutura lógica). Eles apontam para uma dimensão intersubjetiva da linguagem (para além das consciências individuais) como organização do real no reconhecimento que fazemos dele como sendo propriamente "real". Outras abordagens, influenciadas pelo estruturalismo mas que não se prenderam a ele, consideram que a organização da realidade se pauta em outras esferas além da linguagem (enquanto estrutura lógica) por exemplo, na esfera do imaginário, como descrita no capítulo 2.

\subsubsection{Design e sensibilidades}

Neste eixo, o design é encarado em sua dimensão de veiculador de afetos. Embora tenhamos observado, na descrição do eixo anterior, que a linguagem pode balizar boa parte de nossa vivência e até mesmo de nossos afetos, aqui será preciso ressaltar que estes não se reduzem à linguagem. Tal dimensão não redutível à linguagem envolve o que poderíamos chamar de estética, como a caracterização nietzschiana das pulsões estéticas (apolínea e dionisíaca) que, por intermédio de sua interpretação posterior sobre "arte", ${ }^{22}$ pode se mostrar fecunda para pensarmos em nossas ações e intenções não mais sob o registro paradigmático das necessidades e das utilidades. $\mathrm{O}$ design poderia ser encarado, sob este prisma poético (como dimensão criadora da estética), como uma potência em si mesma, como esforço criativo de indivíduos que imaginam o mundo e a si mesmos a partir de seus próprios impulsos de viver. Um

\footnotetext{
${ }^{22} \mathrm{Em} O$ nascimento da tragédia, Nietzsche se vale de uma dicotomia de cunho schopenhaueriano, segundo a qual o belo Apolo (aparência) vela e protege do terrível Dioniso (mundo verdadeiro); faltara ao jovem Nietzsche uma concepção nova, não metafísica, a despeito da arte. Posteriormente, ele viria a desenvolver uma nova e estendida noção de "dionisíaco", na qual vigoraria a suposição de uma única vida que, se afirmada sem restrições, pode ser vivida como obra de arte. Cf. Rabelo, 2013.
} 
design, portanto, entendido como "arte", ao menos de acordo com uma concepção ampla de arte, como aquela descrita por Rogério de Almeida (2015a, p. 182):

\begin{abstract}
A arte, como representante sublime dos artifícios humanos, não é uma mentira, um suplemento ou um atenuante, também não é imitação ou expressão, um modo de iludir, distrair, descontrair ou entreter, também não é um mundo fechado cuja linguagem só pode dizer de sua própria linguagem — arte pela arte —, mas um modo de conhecer o mundo, modo natural, já que entranhado na fisiologia humana. A arte é, assim, o destino do homem: tornar-se consciente de que a mediação que empreende no trato do mundo é de ordem estética, exprime gostos, remete a escolhas, compõe um itinerário e forma-se pelo contato com as formas simbólicas que intensificam o mundo em seus fluxos transcriativos. Religião, ciência, arte, história fazem parte dessas formas que situam o homem no mundo, mas o fazem de modo orgânico, vital (cobram uma adesão visceral que vai muito além das ponderações de ordem racional).
\end{abstract}

Em contrapartida, se pensarmos no título do famoso livro de Victor Papanek (1971), Design para o mundo real, não seria difícil notar que a definição, apresentada pelo autor, de design como "impulso criativo", só adquire sentido mediante sua capciosa defesa de um "mundo real" que, por sua vez, se apresenta como contraparte da teia do mundo "irreal" da imaginação e suas valorações. Num domínio totalmente alheio ao do estético, em que a imaginação e o real estão juntos e são ambos reais uma vez que ambos expressam uma realidade que já está aí —, vemos em Papanek uma rígida conceituação que forçosamente separa, de um lado, a ordem imaginária das coisas e, de outro, o caos do mundo "real", feito de desigualdades sociais e sofrimento humano. E à medida que uma parte é qualificada como "real", a outra parte (a imaginária) automaticamente se torna secundária e supérflua.

Em que pesem as evidentes inconsistências, conforme argumento no capítulo 2, deste tipo de distinção - como se o "mundo real" não fosse antes de tudo um julgamento do intelecto, portanto decorrente da ordem imaginária ("mundo irreal") supostamente descolada daquele —, o ponto a ser aqui destacado é que, se a vida numa concepção nietzschiana só se justifica esteticamente (não conceitualmente), então o "supérfluo" pode ser tão importante quanto o "necessário": é o supérfluo, sobretudo em sua dimensão ritualística, que faz o humano reconhecer-se como ser existente. 
O mundo não existe anteriormente a uma forma que lhe dê seu perfil. Ou existe, mas como algo amorfo, desordenado e sem delimitações e, portanto, sem sentido. Não há uma experiência humana não mediada pela forma, e a cultura é, justamente, um conjunto de esquemas de mediação, um conjunto de formas que delimitam e dão perfis às coisas, às pessoas e, inclusive, a nós mesmos (Larossa, 2010, p. 49).

Afinal, mesmo empreitadas ditas "selvagens" como a guerra, ou aquelas que chamamos de subversivas ou transgressivas, ou ainda as de caráter eminentemente fisiológico, como o ato de comer, são praticadas por nós a partir de certas formas. É pelo fato de tais atos serem regulados formalmente que eles se apresentam como atrelados a um "mundo real". Por conseguinte, os objetos que cercam as atividades humanas são encarados neste eixo como objetos de design na medida em que dão forma à vida humana — seja de maneira supérflua, seja de modo essencial, seja, enfim, qualquer tipo de qualificação a ser posteriormente atribuída a uma forma esteticamente ritualizada. Essa forma permanece sem dúvida conectada à dimensão da linguagem que enfatizamos no eixo anterior, porém, como podemos perceber, a forma das coisas pode também ser encarada como sendo ela própria de natureza estética e, ainda, ontológica, entrecruzando assim com o eixo $\mathrm{V}$.

\subsubsection{Design, ética e tecnologia}

Neste eixo, o design é encarado como um suporte na lida com novas tecnologias e com novas formas de "estar no mundo" por elas impulsionadas. Uma das mais conhecidas referências filosóficas para este eixo é o Ensaio sobre a técnica de Heidegger, ${ }^{23}$ especialmente por ter oferecido pontos de partida para os pensamentos de Sloterdijk, de Latour e de Flusser acerca do tema. A lógica da disposição descrita por Heidegger não condiz aos objetos e tecnologias per se, e sim àquilo que Flusser posteriormente denominou "aparelho": configuração material ou imaterial de um programa predeterminado, que gera não apenas disposições e resultados específicos, mas também a consecutiva privação das possibilidades não inscritas nas coordenadas do programa. Em meados dos anos 1980, Flusser (2008, p. 195) profetizava:

\footnotetext{
${ }^{23}$ Reporto o leitor ao ensaio de Daniel B. Portugal sobre este texto de Heidegger no capítulo Design é bom?, do já mencionado livro Existe design? (Beccari et. al., 2013).
} 
É verdade: o homem enquanto indivíduo disperso e distraído pelos aparelhos, o homem enquanto elemento de massa programada, perdeu definitivamente o controle sobre os aparelhos e enquanto funcionário de aparelhos. Mas outro tipo de homem continua possível: homem que participa de diálogo cósmico "sobre" aparelhos, diálogo possível atualmente graças a técnicas desenvolvidas pelos próprios aparelhos. Semelhante diálogo cósmico sobre e através dos aparelhos poderia resultar em "competência" superior à dos aparelhos. Por certo, tal "competência coletiva" não seria qualitativamente maior que a competência individual humana, mas seria quantitativamente maior: nos aparelhos, as competências são apenas quantitativas.

Ao contrário do que poderia suscitar uma leitura apressada, nem Heidegger nem Flusser propuseram uma espécie de fuga ou resistência, como uma simples oposição coibidora ao processo cego da determinação técnico-programática. Heidegger é justamente o filósofo que percebe que o humano sempre "está no mundo", que não existe sujeito fora do mundo; por sua vez, Flusser é o filósofo que elogia a superficialidade, reconhecendo que são as "caixas-pretas" que fornecem respostas aos problemas que elas mesmas nos colocam. Ou seja, é sempre num mundo específico que o sujeito se localiza, de tal modo que, como observa Latour (2014, p. 12) ao comentar a "esferologia" de Sloterdijk, "definir os humanos significa definir as embalagens, os sistemas de suporte de vida, o Umwelt [mundo ao redor] que nos permite respirar. É exatamente isso que o humanismo nunca percebeu".

O design aparece aqui, então, como sendo a atividade que elabora tais "embalagens" (isto é, a interface para com o mundo no qual nos inserimos), a atividade mediadora da relação entre o homem e os "sistemas de suporte de vida". Sob este viés, enfim, o próprio humano é definido como um designer, na medida em que o que o caracteriza é exatamente viver numa embalagem por ele criada, ainda que parcialmente por ele controlada. É preciso ler, nesta perspectiva, o título do livro de Tony Fry (2013) ao pé da letra: estamos sempre e continuamente "tornando-nos humanos pelo design". A dimensão da linguagem, que guiava o entendimento do design no primeiro eixo, aparece aqui, então, como tão somente mais uma embalagem, ou como um dos tecidos a partir dos quais as embalagens são confeccionadas.

\subsubsection{Design, consumo e cultura midiática}


Neste eixo, o design é encarado como elemento constituinte das culturas pautadas pela centralidade do consumo e da mídia. Entram em pauta, aqui, as relações multifacetadas e simbióticas entre movimentos artísticos, movimentos intelectuais e movimentos de design. O design que começa a ganhar força com o art nouveau, por exemplo, é indissociável da ideia de uma democratização do consumo e de sua passagem da esfera privada dos salões aristocráticos para o espaço público do comércio. É em meados do século XIX, afinal — quando surgem as lojas de departamento e as vitrines -, que os produtos começam a ser expostos para o deleite visual dos transeuntes, com explícito objetivo de sedução. E é claramente em tal contexto que emergem, ao menos sob o ponto de vista das implicações socioculturais, a publicidade e o design tal como os conhecemos hoje.

O consumo começa a assumir aí um papel indispensável como mediador das relações sociais nas grandes cidades. Consumo entendido aqui, de acordo com a definição de Rocha $(2010$, p. 85$)$ - que em certa medida retoma a proposição de Baudrillard sintetizada no eixo I - , como "um processo social permanente de seres humanos definindo-se num espelho de objetos e a estes num espelho de homens". Ora, é a publicidade e o design (tal como encarado neste eixo) que impulsionam e balizam tais "espelhamentos" - que, numa ótica materialista, seriam pejorativamente designados como "fetichismo da mercadoria". Muitas das primeiras teorias que atribuíram lugar central ao consumo ou à "sociedade de consumo" tendiam a encarar o consumo e a comunicação em massa (mass media) como atividades alienantes, que afastavam as massas de sua liberdade ou de um modo de vida autêntico.

Contudo, para quem busca encarar o humano de maneira filosóficoantropológica, isto é, sem querer defini-lo única e exclusivamente pela materialidade do trabalho ou do domínio econômico, o fetichismo da mercadoria pode ser encarado simplesmente como uma forma, dentre outras, de vinculação com objetos e imagens. Pois em comparação, por exemplo, aos rituais ancestrais que envolviam totens, máscaras e magias, o consumo contemporâneo não deixa de envolver uma espécie de personalidade que é "magicamente" transferida ao consumidor que, ao consumir, também veste uma espécie de "máscara". Esse olhar poderia trazer ao primeiro plano a dimensão estética, conforme aponta Jurandir Freire-Costa (2005, p. 180): "Sem os objetos [...], o fato emocional não teria como se tornar visível, entendível e partilhável por todos”. Aqui, porém, já poderíamos levar a reflexão de volta ao escopo do eixo II. 


\subsubsection{Design, epistemologia e ontologia}

Neste eixo, o design é encarado como um modo específico de pensamento, de conhecimento e de articulação de "modos de ser". Grosso modo, a epistemologia pode ser definida como uma teoria geral do conhecimento, da maneira como apreendemos o mundo e o traduzimos em conceitos; ontologia, por sua vez, diz respeito à questão sobre o que é o ser, em que consiste o existir enquanto ação (distinguindo-se da metafísica, que se questiona sobre a existência para além dela mesma), como se dão os múltiplos "modos de ser" etc. Sendo assim, uma das primeiras perguntas a serem feitas aqui não poderia ser outra senão: o que é o real? Como vimos no eixo II, é comum recorrer a um par conceitual (real-irreal, real-ilusão etc.) para se obter uma resposta rápida. Mas essa estratégia não acaba criando apenas uma divisão arbitrária entre real e qualquer outra coisa? E, no entanto, se dispensarmos tal estratégia, o que dizer efetivamente sobre o real que não possa ser explorado em seus próprios termos? Por exemplo: se real é tudo o que existe, seu oposto é o nada, aquilo que não existe. Mas este "nada" não deixa de ser uma das representações do que pode existir.

Conforme retomaremos mais à frente, no capítulo 2, a própria tentativa de se definir um "oposto" ao real não apenas é difícil, mas também, em última instância, inútil. Porque se tudo que percebemos, pensamos, imaginamos e sentimos já se insere no real, então já sabemos o que ele é. O que não sabemos é o que ele não é, de modo que toda tentativa regulatória de separar o que é e o que deixa de ser real parece contradizer-se de imediato. Ainda assim, mesmo já sabendo o que é o real, insistimos em traduzi-lo de algum modo - e aqui já podemos passar à dimensão ontológica: o que é este modo de existir somente por meio de construções conceituais, narrativas, científicas etc.? Os estruturalistas diriam que toda percepção, constatação e experiência é, antes, uma interpretação, uma conceituação, uma estrutura significativa. Sob um ponto de vista nietzschiano, todavia, é o homem que tende a substituir por conceitos e ideias a realidade que já está aí. Não é que os significados sejam "irreais", mas sim que foram inventados pelo homem que, por sua vez, não apenas já faz parte do real, como também não cessa de querer conhecê-lo, traduzi-lo e imaginá-lo.

Por meio desse tipo de reflexão, podemos interrogar sobre a possibilidade de pensar o design não tanto "para além", mas de um modo transversal a suas dimensões culturais, estéticas, tecnológicas, históricas etc. Uma das possibilidades, como a 
proposta neste trabalho, seria a de pensá-lo como "articulação simbólica" que perpassa o real e o imaginário. Neste caso, abarcaríamos também o eixo II, uma vez que o imaginário não será aqui entendido como ilusório (concepção racionalista tradicional) ou de algum modo oposto ao real. O imaginário enquanto conjunto de imagens e também como dinamismo gerador de sentido (Durand, 1997) é o que organiza uma realidade que, em si, é sem sentido — não há sentido que não seja imaginado pelo homem. Nessa perspectiva, a articulação simbólica refere-se ao constante processo de mediação e (re)criação de significados e interpretações que se abrem por meio do design. O que nos leva a perguntar: como se dá o imaginário do design? Eis a ênfase do eixo vigente, que recai na ampla e abrangente questão acerca da maneira particular com a qual o design conjuga diferentes interpretações e "modos de ser".

Após a descrição dos cinco eixos, ficam claras, para além dos contornos gerais de cada um deles, também as possíveis conexões ou ressonâncias de um eixo a outro. $\mathrm{O}$ objetivo da organização dos eixos, portanto, não é o de fundar, justificar ou legitimar qualquer proposição filosófica em relação ao design, como a que apresentarei nos capítulos seguintes. Além de fomentar novas reflexões e propostas, este delineamento visa dimensionar dinamicamente a potencialidade de uma filosofia do design — sem se deter, portanto, em questões de detalhe, como recortes e alcances metodológicos, mas demonstrando certa "engrenagem" de uma expressão filosófica criativa. Por este motivo, os referenciais foram rápida e grosseiramente mencionados ao longo dos eixos, como que compondo uma "constelação mínima" a partir da qual podemos obter um panorama telescópico e cujo desenvolvimento cuidadoso exigiria um trabalho mais focado. O que apresentarei a seguir, portanto, é nada mais que uma lente apontada a uma pequena estrela em meio à constelação aqui rapidamente esboçada. 


\section{INTERLÚDIO II:}

\section{É difícil defender-se com palavras}

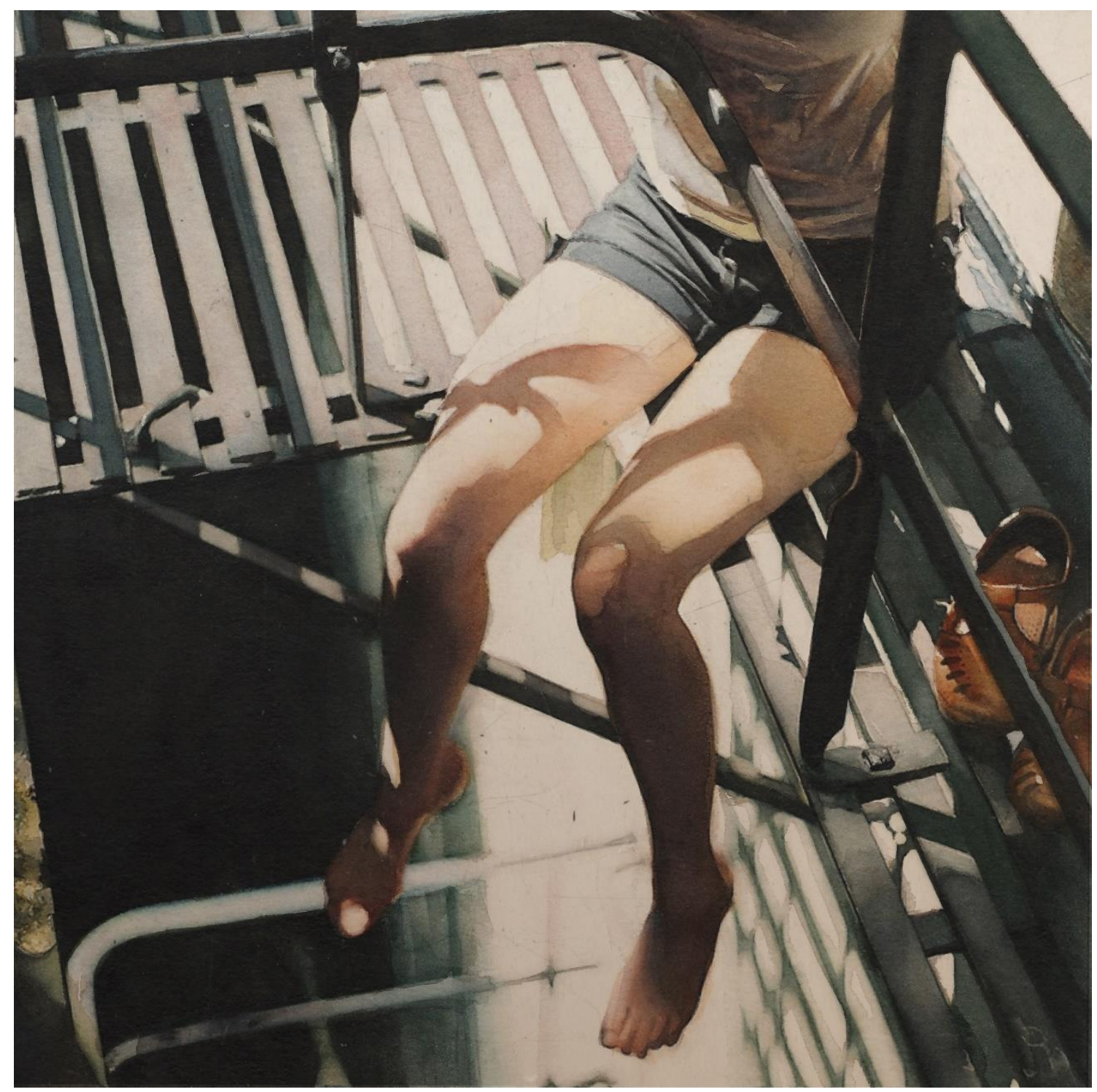

É preciso perder-se entre os que não conhecemos para que subitamente recolham o que é nosso da rua, da areia, das folhas caídas mil anos no mesmo bosque.

- Pablo Neruda, Confesso que vivi.

É a partir dos encontros que se estabelecem as convenções ou é das convenções que se estabelecem os encontros? Um encontro é ao acaso na medida em que a chance de que ele aconteça não é afetada pelo fato de ele já ter ou não acontecido. Mas sem a estabilidade relativa das convenções, um encontro sequer se deixaria notar. Um encontro é menos verdadeiro quando é inventado ou quando nem é notado? 
O espaço é protagonista dos encontros.

Não sei bem como tudo aconteceu, simplesmente foi acontecendo. A mentira é tinta fresca. Quando criança, eu adorava aquele suco colorido que vinha em formato de revólver, avião ou jacaré, porque minha mãe dizia para tomar só um Yakult por dia. Que o guarda-chuva não era brinquedo e não servia como paraquedas. E que se eu me comportasse, ganharia o videogame de que meus colegas da escola tanto falavam. Mas depois seria somente meu pai quem conseguiria "passar de fase", porque eu cansava rápido e tinha medo dos vilões.

Sonhava com o dia em que eu seria forte e seguro como meu pai. Com aquele olhar severo, manobrava com destreza o carro, a chave de fenda, os pinceis... Sim, ele fazia paisagens em telas brancas quando voltava do trabalho. E eu lhe mostrava meus desenhos. Aprovava-os, mas com o adendo de que isto ou aquilo podia estar melhor. Então eu mostrava para minha mãe, para me envaidecer de ser o melhor nessa coisa de rabiscar. Com o tempo eu preenchia mais e mais folhas, o lápis engolindo a possibilidade de fuga pelo olhar, o provisório tomando ritmo e forma.

É isto o que me interessava: nenhum desenho acabado, somente um papel a ser preenchido. Esta menina aqui, por exemplo: quando a desenhei, ela estava lá, depois não estava mais. Mas naquele momento, naquele exato momento, eu prestei atenção e vi: as coisas mudam. Não há o que pensar a respeito e não se pode esperar. Enquanto ela, do outro lado do papel, não me via. Viu como tudo é real?

Quando corremos atrás da nossa sombra, ela foge. Quando fugimos, ela corre atrás. $\mathrm{O}$ cérebro é um bicho que come pensamentos, mastiga, engasga e cospe fora. Se a filosofia pudesse oferecer respostas, programas de auditórios deveriam ser gravados e estocados no porão da Sorbonne. Houve um tempo em que preservativos eram feitos de tripa de carneiro e o alto índice de natalidade era contrabalanceado pela morte prematura. Contra o mau hálito inventaram as pastilhas de menta.

O acaso é o que acontece. É o que faz com que aconteça o que acontece. Às vezes o silêncio é um acontecimento. Outras vezes, não precisa acontecer nada.

O encontro é protagonista do tempo.

Eu balançava os braços enquanto o quadro-negro comia o branco do meu giz. Entre o giz e a superfície, mantinha-se o atrito mínimo para eu soltar as palavras. O suficiente para eu escutar os alunos anotando no caderno, copiando aquilo que eu copiava dos livros. Como numa dança, as palavras suspensas pousavam nos olhos. $\mathrm{O}$ toquinho de giz ainda deslizava quando um aluno perguntou o que significa "amiúde". 
Olhavam-me enquanto eu mirava seus olhos miúdos. Estrábicos. Era como se ele não olhasse para mim. Mas olhava, atentamente. Gaguejei sobre como é frequente, recorrente, amiúde a pergunta dele. E que é muito importante fazer perguntas quando não sabemos o que significa uma palavra.

Não queria olhar tanto, olhei apenas por um segundo, um mínimo segundo. $\mathrm{O}$ que fazer depois de ter avistado a perfeição? Era de tirar o fôlego. Estava ali, naquele olhar solto, difuso, imperfeito, a resposta para todas as questões. Se algo menor lhe faltava, era para elogiar as coisas inacabadas, inconclusas, fortes, incorruptíveis. Fiquei pequeno na frente dele. O que mais poderia ser ensinado no exato instante em que os deuses todos se reuniram por tão máxima urgência? A palavra "amiúde", ao alcance das mãos, era a única coisa. Não fosse isso, seria menos. Não fosse tanto, nada seria. 


\section{FILOSOFIA TRÁGICA}

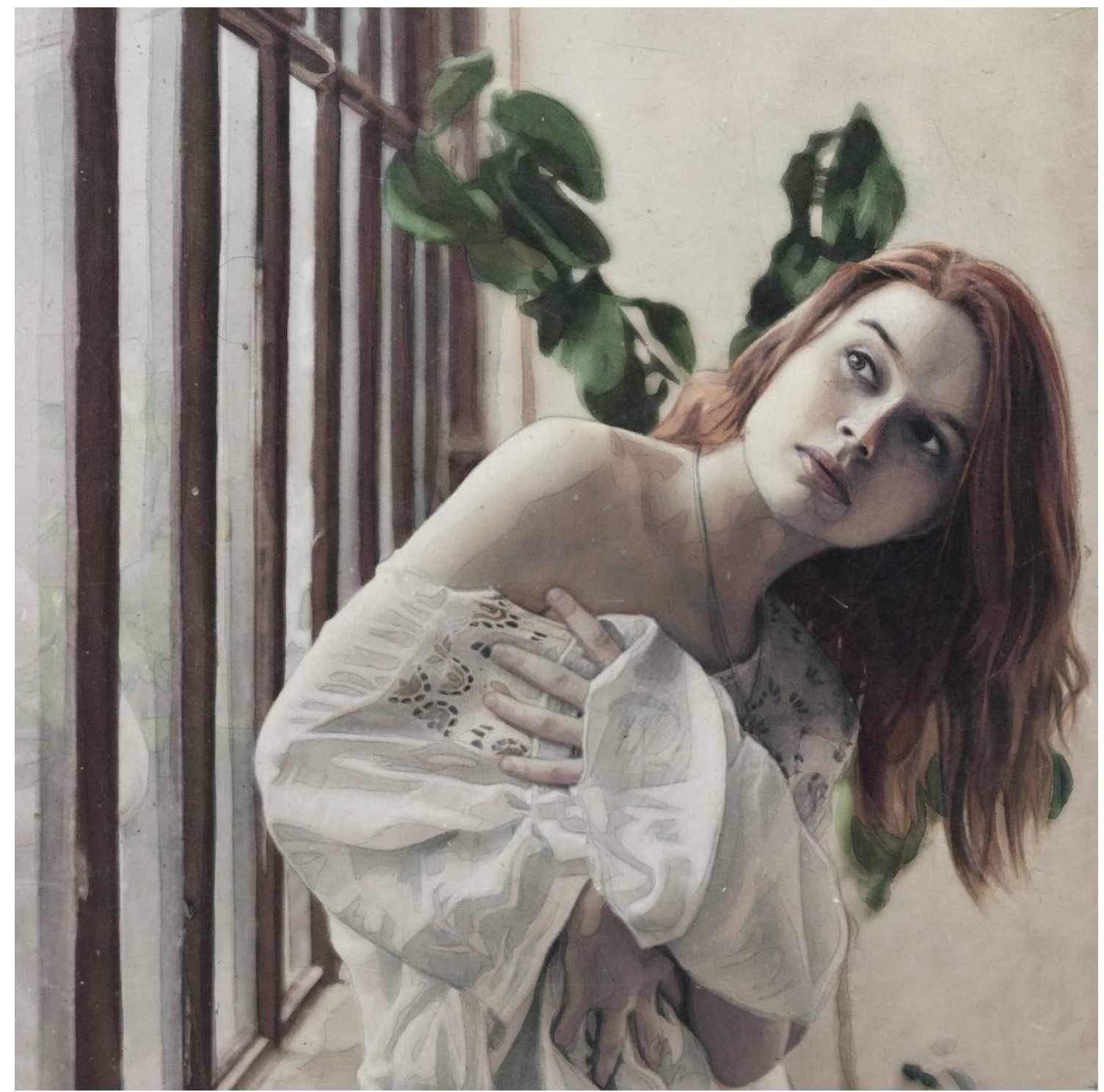

Somos contos contando contos, nada.

— Ricardo Reis [Fernando Pessoa].

Gosto de pensar que o peixe é quem menos sabe da água em que está submerso. Não que isso seja verdade, vai saber, ao menos acho divertida a imagem do peixe intelectual que discursa sobre a "água", essa expressão de uma classe privilegiada diante 
da multidão de peixes mais preocupados em continuar "voando" por aí. ${ }^{24}$ E talvez aquele peixe também não se importe muito com tal abstração filosófica, ou quem sabe ele espera encontrá-la num plano superior-divino, ou ainda tal expressão talvez seja apenas o modo como ele tenta enxergar um palmo diante do nariz.

Seja como for, acredito que não enxergar a água por vezes pode ser uma boa estratégia para não se afogar - o que para nós seres humanos significa que talvez não seja uma boa ideia viver como se a "verdade-em-si" já existisse de antemão lá onde queremos vê-la. Não fosse assim, bastaria eu apontar o dedo e, constatando que as pessoas veem o mesmo que eu vejo, não haveria mais o que dizer sobre isso. Mas desde o início o que todos veem não é a mesma água, e sim aquilo que aparece por meio dela, mediante cada olhar e no entrecruzamento de olhares. Meu ponto é que estamos sempre imaginando uma "água" que, no entanto, nunca deixou de ser real. Em outras palavras, o imaginário não é contrário ao real, mas parte constitutiva dele ou, ainda, aquilo que o organiza. Ou melhor: o imaginário dota de sentido uma realidade que é sem sentido. Logo, negar totalmente a existência da água em proveito de uma realidade mais transparente, mais profunda ou mais verdadeira significa tentar enxergar a "alienação" da água para finalmente sair dela, afogando-se do mesmo jeito. Afinal, o que dizer efetivamente sobre o real que seja tão diferente do imaginário?

Tomemos a célebre alegoria platônica da caverna, cuja moral é a de que percebemos a realidade sob um ponto de vista limitado ou distorcido, confundindo falsas imagens com as coisas reais. Ora, para verificar essa hipótese, seria preciso estar na posição de um observador externo que, em seu suposto olhar "de cima", poderia distinguir a realidade verdadeira da percepção errada e distorcida. Mesmo a suposição de haver meta-cavernas, realidades paralelas ou mergulhadas umas nas outras pressupõe este mesmo olhar "de cima", portanto a expectativa de que exista um nível mais verdadeiro do que o das aparências. Há ainda o observador "dialético" que enxerga a ele próprio como uma sombra na parede, efeito duvidoso de um longo processo de destilar e extrair pistas das pequenas inconsistências do mundo em que vive. Em todo caso, trata-se de um olhar desconfiado que só admite o que vê com a condição de que haja um modelo original do que é visto, ou com a condição de que haja infinitos modelos possíveis, podendo até concluir que não existe nada além de "cavernas" — a constante é

\footnotetext{
${ }^{24}$ Esta imagem eu tomei emprestada do discurso de David Foster Wallace intitulado This is water, proferido na formatura dos alunos do Kenyon College em 2005. Disponível em: https://youtu.be/8CrOLydFMI. Acesso em: 11 jul. 2015.
} 
a negação do real, não por um elogio à ilusão, mas justamente em nome do Real.

É acerca desta insidiosa ruptura ou "dialetização" entre real e imaginário que devemos, neste capítulo, nos ater. Por mais que haja uma infinidade de concepções sobre a materialidade, a natureza, a estrutura e a verdade do real, toda conceituação do real não é possível senão por meio de um par (real-irreal, real-imaginário, real-ilusão etc.). Mesmo no caso de Nietzsche ou Clément Rosset, autores que a seguir nos serão fundamentais, a estratégia é abordar os meios com os quais se ludibria ou se tenta ludibriar o real, constituindo portanto mais uma filosofia sobre a ilusão do que propriamente sobre o real. Com efeito, não será o caso aqui de definir o real (a não ser provisoriamente, no tópico 2.2), mas antes de problematizá-lo, utilizando-o como passagem ou atalho para uma abordagem hermenêutica, isto é, que privilegie a leitura, a interpretação, o "design” como interface do real. Se desde o início coloquei em questão a possibilidade de pensar o design para além das abordagens econômicas, funcionalistas, pragmáticas etc., devo agora explanar filosoficamente de que maneira é possível pensá-lo como "articulação simbólica" que perpassa o real e o imaginário.

E ao problematizar o real (ou melhor, as conceituações sobre o real), estarei ao mesmo tempo problematizando o imaginário. Se o real e o imaginário estão juntos, são o mesmo, já que o imaginário dota de sentido uma realidade que não possui sentido inerente, é importante assimilar em que medida o imaginário não é sempre ilusório (como na concepção racionalista tradicional), nem estaria preso à linguagem (como em Wittgenstein), nem representaria uma dimensão libidinosa (como na psicanálise) ou enfim seria, de algum modo, oposto ao real. O que é oposto ao real, conceitualmente, é a ilusão - nestes termos, poderíamos falar num imaginário da ilusão e num imaginário do real. Significa que nem todo imaginário é real? Sem dúvida, mas não no sentido de que escapa do real, e sim de poder negá-lo ou retocá-lo. A questão, portanto, é que o imaginário expressa em linguagem humana (coerente, lógica, metafórica, afetiva, imagética, discursiva, interpretativa etc.) uma realidade que está aí.

Compreender essa relação entre imaginário e real, bem como as mediações que os entrelaça, será imprescindível para avançarmos num procedimento metodológico pautado nesta mesma relação. Qual seja, algum caminho que nos permita pensar no design enquanto articulação simbólica, isto é, como agenciamento ficcional de quem somos em relação a uma existência socialmente partilhada. Pensemos na experiência de assistir a um filme: analogamente ao fato de as imagens descontínuas do cinema nada indicarem, isoladamente, em relação ao mecanismo do movimento que as liga umas às 
outras perante nossos olhos, o que sentimos e assimilamos ao assistirmos a uma película cinematográfica não é "transmitido" pela película em si, mas se conjuga na ficção projetada pelo espectador, no diálogo que se abre ao localizarmos a nós mesmos em relação ao filme. Trata-se então de uma visada hermenêutica (que apresento no capítulo 3), um modo de pensar que elege a ficção e a interpretação como processos que instauram continuamente a experiência de existir.

Neste ínterim, a hermenêutica simbólica proposta por Paul Ricoeur nos será pertinente para, no capítulo 4, apostarmos na tese de que o design opera não apenas como mediação simbólica, mas também como articulação (na medida em que, seguindo nossa fundamentação teórica, a "aparência" das coisas se valha pela própria aparência), tornando-se ponto de convergência para os diversos referenciais em disputa nas controvérsias inerentes a qualquer aposta de compreensão do mundo. Um dos primeiros aspectos que se apresentam mediante uma filosofia da cultura, por exemplo, é a aparente dissonância entre a variabilidade de formas culturais e a redundância de algumas coordenadas de tal variabilidade - como as representações ora contraditórias ora muito semelhantes sobre a morte, o corpo, o apocalipse etc. Só que tais símbolos, dada a ambivalência que lhes é peculiar, valem menos pelo que isoladamente significam do que pelo conjunto em que se inserem e, mais ainda, pelas relações narrativas que os dinamizam (Almeida; Ferreira-Santos, 2012).

Sob um prisma hermenêutico, pois, os suportes materiais ou imateriais importam menos do que o processo simbólico que os circunscreve. Dito de outro modo: uma vez que o imaginário dota de sentido uma realidade que é sem sentido, ao buscarmos o sentido nas coisas (nos discursos, nas narrativas, nas instituições etc.) somos nós que, reciprocamente, atribuímos sentidos às coisas. Este buscar e este atribuir não são movimentos antagônicos, mas antes complementares, porque constituem propriamente o círculo hermenêutico ou, assim o compreenderemos, o círculo ficcional do design. Tomado nesse sentido amplo, o problema no design não é o de falar ou escutar, e sim o de ver e dar-a-ver, perpassando o real e o imaginário.

E o nosso problema, enquanto "designers de si", é o de conseguir narrar e ao mesmo tempo ver-se narrando - conforme detalho no capítulo 4. Em todo caso, não é o mundo que se adapta ao sentido que damos a ele, mas o inverso - destarte, portanto, design implica articular uma história que eu possa chamar de "mundo", conforme defendo também no capítulo 4. Trata-se de articular uma ficção que me permita compreender não só o sentido de minha existência no mundo, como também a 
existência de outros sentidos no mundo onde eu existo.

Mas a existência do mundo em si não precisa ser compreendida, não precisa de nós; quer dizer, é sempre bom manter em mente a imagem do peixe que não enxerga a água. O mundo existe sem sentido intrínseco e nunca conseguimos atribuir-lhe por definitivo um sentido extrínseco. Ainda assim o expressamos, movimentando-nos em meio à agua imaginária que nos envolve, portanto nos esforçando para expressar a nossa existência neste mundo, que assim pode ser vivido e aprovado.

\subsection{DA IMAGEM DO REAL PARA O REAL DA IMAGEM}

Este tópico se debruça sobre teorias que criticam a concepção das aparências como algo traiçoeiro que deveria ser sempre julgado em função de qualquer coisa para além dele. Apoio-me na filosofia trágica, em especial nas de Nietzsche e de Clément Rosset, para mostrar que a relação de complementaridade entre o real e o imaginário pode ser vista não apenas como necessária, mas também como potencial afirmadora da vida, mais do que as concepções que tentam buscar um real inexistente para além dessa relação. Apresento ainda, nos próximos tópicos, definições provisórias acerca do real e do imaginário, como coordenadas interpretativas para avançarmos ao capítulo 3, referente à hermenêutica trágica. De modo geral, percorreremos aqui a tese defendida por Rosset (2006, p. 89) em seu livro Fantasmagorias: "a de que o real não se define por sua relação com o imaginário, mas por sua relação com o ilusório. Em outras palavras, que o imaginário é uma das formas de apreender o real, enquanto a ilusão é a maneira por excelência de negação do real."

Há muitas formas de olhar para o "mundo", isto é, para aquilo que aparece para nós em nossa experiência ordinária. Talvez a mais recorrente ou próxima do senso comum seja encarando as coisas desse mundo como se aquilo que experimentamos por meio dos sentidos (a aparência) existisse independentemente de nós. Essa é uma maneira realista de lidar com o mundo - seja um realismo "prático" que simplesmente toma a aparência como o real, seja um pseudorrealismo que considera uma realidade ou "coisa em si" existente por baixo das imagens. Tal distinção, contudo, muitas vezes não é muito apurada: posso acreditar, por exemplo, que o mundo concreto arranja-se de maneira autônoma, expondo-se diante de nós por uma virtude própria a que nos referimos por "natureza" ou leis da física. Esta espécie de ordem que lhe é própria 
claramente excede a percepção realista na medida em que se trata de uma interpretação segunda que não deriva diretamente de uma experiência primeira.

A partir disso, podemos pensar que, em nossa experiência ordinária, introduzimos como "essenciais" elementos que, na verdade, são derivados da tradução que nossa consciência elabora para reconhecer-se tão existente quanto aquilo que percebe. Por meio deste raciocínio, alguém poderia concluir que o mundo em si mesmo não existe, porque não há como provar sua existência sem um raciocínio, um critério, um modelo ou um observador externo a ele. Esse é um caminho idealista de lidar com o mundo, pois o mesmo precisaria de um suporte ideal, metafísico ou transcendente para justificar-se como "mundo". Novamente, contudo, a distinção entre realismo e idealismo pode aparecer sem muita clareza, como no caso do seguinte contraargumento: mesmo que as coisas estejam sempre para além da "prova" e apareçam como excedentes, o fato é que continuamos a ver coisas que satisfazem (isto é, agem de acordo com) nossa exigência de defini-las como algo em si mesmo.

Este enunciado que se pretende realista-empírico (contendo também traços do idealismo transcendental e do pragmatismo funcionalista) é capaz de justificar certas inferências amplamente disseminadas tais como: o preconceito e o medo expressam nosso instinto de preservação, o amor e a amizade não se isentam do imperativo de competir para sobreviver e, enfim, toda experiência é ordenada a partir de uma suposta programação da espécie ou da sociedade. O raciocínio é que não importa se existe ou não existe, de fato, uma ordem por trás das coisas, o que importa é que a crença nessa ordem já é suficiente para sanar nossos interesses. Por conseguinte, somos de imediato levados a questionar quais interesses são esses que, ao chamarem certas coisas de "natureza", preferem ignorar a arbitrariedade de tal nomeação. Seja qual for, é um interesse que pretende atuar como condição necessária de toda experiência, submetendo assim o mundo a uma estratégia idealista de percebê-lo.

Outra forma de entender nossa relação com o mundo é dizer que ele existe, e nada existe além dele, só que nunca conseguimos percebê-lo exatamente como ele é. Haveria então algum tipo de mediação (como uma imagem, uma aparência, um filtro) que nos impede de enxergar o mundo em si mesmo e que, ao mesmo tempo, seria o que nos dá acesso a ele. Trata-se aqui de uma visada fenomenológica, pois considera o fenômeno como mediação necessária entre um sujeito e algo para além dele. Cumpre levantar, neste ponto, uma questão pertinente para nós: ao considerarmos como necessária tal mediação, não continuaríamos opondo a aparência ao real? 
Sob um prisma trágico, que procede a partir da insuficiência de toda explicação, a resposta depende de uma interpretação fundamental acerca dessa mediação. De um lado, ao estabelecer uma mediação incontornável em relação ao mundo, a fenomenologia ainda pressupõe um acesso idealista, mesmo que negativamente (por meio de procedimentos que tentam "isolar" os fenômenos), reforçando assim a oposição entre aparência e real. De outro, porém, se essa aparência mediadora for entendida como a única coisa efetivamente real, de modo que o eu-observador e a coisa-observada fazem parte de uma mesma aparência, então não temos mais a oposição clássica entre aparência e realidade, e sim uma junção delas — que agora faz frente, finalmente, à ilusão de um "mundo verdadeiro" por trás das aparências.

Tal junção não seria admitida numa abordagem estritamente fenomenológica, que certamente a tomaria como outra mediação, com a desvantagem de pretender despojar a realidade de sua concretude - eis a premissa metafísica da fenomenologia, o que não invalida a vantagem metodológica de uma postura fenomenológica de suspensão dos juízos, tal qual a manifestada por filósofos como Paul Ricoeur e Merleau-Ponty. Em contrapartida, não isolar a realidade de sua aparência, numa perspectiva trágica, é imprescindível caso se queira abandonar a metafísica tradicional, esta cisão entre concretude e aparência, entre inteligibilidade e experiência sensível. Sem uma contraparte ilusória, com efeito, o mundo "verdadeiro" coincide com o aparente, tornando-se enfim alheio a qualquer suporte idealista. É somente por esse caminho que encontraremos um realismo radical, isto é, aquele que é "aprovador do real" na medida em que sabe que a experiência do real dispensa qualquer referência.

\footnotetext{
A maior parte dos pensamentos filosóficos — ou seja, das filosofias nãotrágicas - não são afirmadores porque têm necessidade de um tal referencial para se estimar "fundados" a afirmar. Mesmo se eles desesperam de aí chegar, conservam a ideia de que "há" verdade em alguma parte — senão tudo, para eles, torna-se vão: vida, ação, pensamento, filosofia. O que significa que o trágico (a ausência de verdade, de referencial), se era por eles reconhecido como tal, não poderia ser o objeto de uma aprovação: confirmação da ligação entre trágico e aprovação (Rosset, 1989, p. 57).
}

Imaginemos, para exemplificar a mudança de perspectiva proposta acima por Rosset, que alguém acabou de fazer um desenho e, por acidente, derrubou um vidro de nanquim nesse desenho. Quanto mais a pessoa tentar limpar o nanquim, mais ela 
apagará o desenho que havia ali, de modo que, ao final, sobrará apenas um borrão. Tal situação é análoga à ideia de que, se tentarmos "limpar" a aparência das coisas, não sobrará nada, tudo será perdido definitivamente. De modo que, se não nos habituarmos ao "borrão do mundo", é porque ainda estamos esperando por algum sentido íntimo para além da aparência - mesmo que não seja uma essência platônica, ao menos a tranquilidade de uma universalidade calcada na razão perene.

É nesse sentido que, na concepção nietzschiana, a realidade nunca é tributária do crédito que se concede ou que se deixa de conceder à autoridade de um nível metafísico — esse "para além" da experiência imediata — e seus resquícios seculares (como as noções de natureza, dever moral, identidade etc.). O que não significa, por outro lado, que devemos descartar todo discurso a respeito de justiça, liberdade, igualdade e bondade em nome de uma "dura realidade" de como as coisas "realmente são"—. Com tal argumento, cairíamos novamente na ilusão metafísica. $\mathrm{O}$ engodo nisso consiste em colocar em oposição os discursos sobre o real, o que implica colocar suas tentativas de regulação em oposição ao próprio real. Destarte devemos assimilar, aos poucos, a sutileza que envolve um olhar trágico perante as armadilhas idealistas.

\footnotetext{
Não se pode desenraizar aquilo que não tem raízes. Donde o caráter inatacável de todo fanatismo, [...] toda crença se definindo, não por um conteúdo, mas por um modo de adesão, é previsível que toda destruição de crença culminará na substituição por uma crença nova que reporá, sobre um novo pseudoconteúdo, uma mesma maneira de crer (Rosset, 1989, p. 45).
}

Continuando a reflexão gerada pelo exemplo do desenho manchado, vale sublinhar que não se trata de dizer que a realidade é necessariamente um borrão, e sim que ela pode facilmente se assimilar a um quando tentamos "retocá-la" — o que dá no mesmo que tentar enxergar, para além dela, algum divino modelo que a fundamente. $\mathrm{O}$ jargão de que "as aparências enganam" resume o diagnóstico do sentimento metafísico de insuficiência e de falta acerca da realidade em geral e de toda experiência em particular. Ou seja, se muitas vezes o que vemos é um borrão, falta de sentido ou de ordem, isso não se deve à imperfeição da ordem do mundo sensível frente a ordens cósmicas ou naturais, e sim unicamente ao fato de que esperávamos outro sentido ou outra ordem que não aquela que nos foi dada.

É sob esse prisma que podemos caracterizar a experiência de realidade, nos 
termos de Rosset (2006, p. 69), como sendo "sua própria fantasmagoria, e a única maneira apropriada de tratá-la é escrever um compêndio das aparências", de modo que, ao querer limpar o real das ilusões que o velam, "corremos o risco de, simplesmente, anular o real e jogar fora o bebê com a água suja do banho".

Donde seguimos para outra questão pertinente: mas ao pressupor que há ilusões que nos afastam do real, ou que o anulam, não estaríamos criando uma nova contraparte ilusória? Vejamos como a questão é bem mais simples do que isso: quando ouvimos um gato miar, não ouvimos latidos, e sim miados. Apenas se encararmos o gato por aquilo que ele não é, mas poderia ser, é que faz sentido uma queixa de "falta de latidos" aqui, não se trata de aparência, trata-se de ilusão. A ilusão não é uma contraparte do real, é apenas outro sentido ou outra ordem que não aquela que nos foi dada, mas que insistimos em querer ver. Noutros termos, o engodo ilusório reside em tudo o que o real poderia ainda nos revelar e, não revelando, logo é tido como "insuficiente" (para quem? Para o olhar que não o aprova tal como ele nos aparece).

"De fato, nada até agora teve uma mais ingênua força persuasiva do que o erro do ser, tal como foi, por exemplo, formulado pelos eleatas: pois esse erro tem a seu favor cada palavra, cada proposição que nós falamos!” (Nietzsche, 2006, § 5). Esta passagem nos ajuda a compreender como o intelecto pode tornar-se mestre da ilusão ao levar a cabo a tarefa de ordenar racionalmente o mundo. $\mathrm{O}$ argumento de Nietzsche é o de que quaisquer conceitos, ainda que formulados inicialmente como instrumentos de expressão do real, tendem a uma fixação não apenas do real, mas também da linguagem que lhe atribui significado, correndo o risco de trocar e "fixar" um pelo outro. ${ }^{25}$

Significa que o problema são os conceitos? Evidente que não, pois somos nós que os elaboramos para expressar valores e ideias. A questão é que tais valores e ideias não existem "noutro lugar", como pensava Platão, nem "neles próprios", como pensava Kant, muito menos sob a forma de "partes dialéticas", como queria Hegel. Valores e ideias são inventados e, ao serem transformados em conceitos, correm o risco de serem naturalizados, ou seja, encerrados como fatos pressupostos. Tendo isso em mente, não vemos em Nietzsche a questão do "Ser", apenas a dos sentidos de ser; do mesmo modo, o clássico problema filosófico de como saber se o sentido das palavras se refere a objetos reais aparece em Nietzsche como um falso problema. Afinal, o real "sempre

\footnotetext{
${ }^{25}$ A este respeito, conferir o conhecido texto de Nietzsche intitulado "Sobre a verdade e a mentira no sentido extramoral", publicado postumamente no Oeuvres Philosophiques Complètes, I, 2, Écrits Posthumes: 1870-1873 (Paris: Ed. Gallimard, 1975). No Brasil, esse texto consta na antologia Obras Incompletas (Nietzsche, 1999, p. 51-60).
} 
supera as descrições intelectuais que possam ser feitas sobre ele” (Rosset, 2006, p. 74), o que não nos impede, contudo, de usar palavras e conceitos para expressar nossa relação com o mundo, de modo que as palavras e os conceitos não sirvam para adequar o mundo aos valores e ideias que temos dele, mas o contrário.

Com base nesse raciocínio nietzschiano, podemos avançar na questão da ilusão por meio da distinção oferecida por Rosset (idem) entre o "duplo de duplicação" e o "duplo de substituição", ambos sendo estratégias reativas ao real. A primeira tática consiste em duplicar alguma coisa, como nas diversas ocasiões em que fazemos comparação, analogia ou confusão (entre pessoas, eventos, histórias etc.) que até "podem provocar a dúvida de quem é o duplo e quem é o modelo; mas em nenhum momento restará dúvida de que há um duplo e um modelo" (ibidem, p. 76).

Esse tipo de estratégia não é ilusório, e sim ficcional, porque se serve de uma dinâmica imaginativa para assimilar o real. É como noção nietzschiana de "máscara" (Nietzsche, 2005, § 40), cujo princípio é a completa ausência de um "fundo" último - a criança dissimula sem culpa e vive de máscaras como se estivesse sempre numa eterna brincadeira - ou ainda como os próprios rótulos, convenções e outros artifícios nos quais se engendram nossas valorações.

Bem diferente é o duplo de substituição, cuja função é a de "eliminar o original fazendo-se passar por ele graças a um efeito de alternativa que afirma sua existência por meio da eliminação de seu modelo" (Rosset, 2006, p. 76). São as ocasiões em que recorremos à fantasia para fugir de alguma situação inconveniente, ou em que tentamos negar ou retocar aquilo que nos aparece, enfim, quando fingimos que não vimos o que vimos e vice-versa. Tal estratégia de esconder algum aspecto do real "debaixo do tapete" é ilusória uma vez que a imaginação é endereçada para substituir o real.

O curioso é que, de acordo com Rosset (ibidem, p. 77), "por mais que o duplo [de substituição] enterre o real o maior tempo possível, este sempre acaba retornando à superfície, nem que seja de modo especular". É o que Woody Allen parece ilustrar numa das últimas cenas de Match Point (2005), quando o protagonista Chris se depara, de madrugada, com o fantasma de sua amante Nola e da vizinha, ambas assassinadas por ele. Chris diz a Nola que não foi fácil, mas que quando chegou a hora ele puxou o gatilho, e que depois foi só uma questão de esconder as provas e seguir em frente. Ocorre que o retorno "especular" do real, neste caso, não residiu nessa assombração imaginária (Chris não se sentia culpado), nem num possível castigo (que não veio a acontecer), mas justamente na ausência de qualquer regulação ilusória como a noção de 
"justiça”. Eis a artimanha trágica de Woody Allen: mostrar que a ilusão não ocorreu por parte de Chris (que afinal não substituiu nada, ele apenas agiu sobre o real), e sim por parte do espectador que esperava um desfecho "adequado" à gravidade do delito.

Não é difícil perceber, pois, que mesmo esta separação entre duplicação e substituição, reconhecidamente elaborada por Rosset "na falta de uma distinção melhor", nunca é muito precisa, sendo apenas útil para demonstrar a versatilidade da imaginação no que diz respeito à assimilação ou dissimulação do real. Portanto, serve também como atalho para pensarmos no imaginário que, assim como o real, vale menos como um princípio do que como uma dinâmica de funcionamento das imagens.

Para precisar tal dinâmica, cabe aqui mencionar a concepção spinozista acerca da ilusão. Segundo Spinoza (2007), a mente é a ideia do corpo, ou seja, uma representação em termos de conceitos e imagens das muitas maneiras pelas quais nosso corpo pode afetar e ser afetado pelo mundo - em poucas palavras, a mente se "imagina" a partir do corpo. Por conseguinte, a dinâmica da imaginação segue um fluxo de afecções que se implicam continuamente: assimilamos as coisas apenas à medida que nos afetam, e elas nos afetam apenas à medida que reconhecemos, em suas imagens, uma imagem de nós próprios. Nesse sentido, a ilusão consiste na estabilização da imaginação por meio da crença numa razão separada do mundo, do corpo e de seus afetos, de modo a imaginar causas para os fatos. A imagem comuta-se em necessidade: sem levar em conta que a mente só reflete a maneira pela qual percebemos as relações, imaginamos que estas se apresentam, por coincidência, sob uma ordem tal que podemos explicá-las pela consciência que temos delas - eis o modo ilusório de imaginar.

“[...] como se a ordenação fosse algo que, independentemente da nossa imaginação, existisse na natureza" (Spinoza, 2007, p. 46). Em todo caso, a imaginação é sempre uma criação que interage com o mundo, seja aceitando a imersão do homem nele, seja recusando-a em prol de valores dados como necessários. Imaginar de maneira não ilusória, com efeito, consiste em criar a partir de nossa inserção no mundo, portanto a partir do que é comum a ele e a nós: nossos afetos. ${ }^{26}$ É nesse registro, aliás, que devemos compreender a constante valorização nietzschiana da aparência e da ficção não apenas como estratégia de inversão da metafísica (cujo mote é a revelação da Verdade), mas também como formas de assimilação do real que elegem a afirmação da vida como

26 "Por afeto compreendo as afecções do corpo, pelas quais sua potência de agir é aumentada ou diminuída, estimulada ou refreada, e, ao mesmo tempo, as ideias dessas afecções. Assim, quando podemos ser a causa adequada de alguma dessas afecções, por afeto compreendo, então, uma ação" (Spinoza, 2007, III, definição 3, p. 98). 
critério de avaliação — conforme Nietzsche (2006, III, § 6) resume em quatro teses:

Primeira tese. As razões que fizeram "este" mundo ser designado como aparente justificam, isto sim, a sua realidade — uma outra espécie de realidade é absolutamente indemonstrável.

Segunda tese. As características dadas ao "verdadeiro ser" das coisas são as características do não-ser, do nada - construiu-se o "mundo verdadeiro" a partir da contradição ao mundo real: um mundo aparente, de fato, na medida em que é apenas uma ilusão ótico-moral.

Terceira tese. Não há sentido em fabular acerca de um "outro" mundo, a menos que um instinto de calúnia, apequenamento e suspeição da vida seja poderoso em nós: nesse caso, vingamo-nos da vida com a fantasmagoria de uma vida "outra", "melhor".

Quarta tese. Dividir o mundo em um "verdadeiro" e um "aparente", seja à maneira do cristianismo, seja à maneira de Kant (um cristão insidioso, afinal de contas), é apenas uma sugestão da décadence — um sintoma da vida que declina... O fato de o artista estimar a aparência mais que a realidade não é objeção a essa tese. Pois "a aparência" significa, nesse caso, novamente a realidade, mas numa seleção, correção, reforço... O artista trágico não é um pessimista - ele diz justamente Sim a tudo questionável e mesmo terrível, ele é dionisíaco...

A despeito do aspecto afirmativo da aparência/ficção, outra película de Woody Allen é elucidativa: em Meia-noite em Paris (2011), a fantasia nostálgica de que só é possível ser feliz no passado é alimentada por Gil, o protagonista, que após transitar pelo passado, no entanto, prefere finalmente viver no presente. ${ }^{27}$ Essa escolha não implica a recusa da fantasia sobre o passado, mas a integração deste passado ao presente (indicada no filme pela imagem do antiquário) e, portanto, da fantasia ao real. Temos então que ilusão e imaginação se concatenam no real, por vezes de maneira especular e negativa, mas em todo caso confirmando a presença e o funcionamento ficcional do real. Quer dizer que uma pessoa privada de uma "função do imaginário" pode ser tão perturbada quanto alguém privado de uma "função do real"?

Certamente que sim, embora ainda nos caiba detalhar um pouco mais tais funções. Não é que real e imaginário se percam um no outro, como se não houvesse, por exemplo, diferença entre sonho e realidade. Nos termos de Rosset (2006, p. 106): “que

\footnotetext{
${ }^{27}$ Cf. a detalhada análise feita por Rogério de Almeida sobre esse filme, publicada em: Almeida; FerreiraSantos, 2012, p. 39-52.
} 
há uma diferença entre a imaginação e o real [...] não resta, a princípio, a menor dúvida; mas que entre ambos exista uma ruptura é algo, pelo contrário, muito mais duvidoso." Por mais que a ilusão, que deriva do imaginário, queira negar o real, ela não impede "uma associação regular entre o real e o imaginário" (ibidem, p. 107). Rosset então recorre ao célebre exemplo de Dom Quixote, sinalizando que, embora o cavaleiro errante imagine o mundo com certa extravagância, ele não promove divórcio algum entre o real e o imaginário. O que Dom Quixote faz frequentemente são somente alguns acréscimos imaginários que não logram em lhe turvar a visão. Mais do que isso:

\footnotetext{
O real de que se trata [na narrativa de Cervantes] é sempre o mesmo, mas revelando-se numa cena não habitual que configura uma espécie de espaço protegido; entendendo por tal lugar não um lugar de escapatória do real, mas, ao contrário, um lugar onde o real está preservado, protegido daquilo que há de constitucionalmente frágil na realidade mesma (Rosset, 2006, p. 112).
}

O que pode haver de "constitucionalmente frágil" no real não é outra coisa senão o imaginário pelo qual nos localizamos nele. Dom Quixote recorre à imaginação para proteger o real - protegê-lo do quê? Da imaginação mesma. Afinal, se a ilusão é, como vimos, um dos modos de operar do imaginário, não há contradição alguma em recorrer ao próprio imaginário para evitar suas armadilhas ilusórias - são delas, por certo, que o real pode ser "preservado". Preservar o real significa cultivá-lo enquanto aparência, mantê-lo enquanto experiência sensível, o que não se confunde com "concertar o real", seja retocando-o ou substituindo-o. Para pontuar essa diferença, Rosset (ibidem, p. 114) passa para o exemplo de Madame Bovary (de Flaubert), “cujos sonhos não envolvem a construção de um mundo imaginário, mas sim uma contínua rejeição de toda realidade tangível". Quanto mais a protagonista se esforça para sair da "prisão" que considera ser sua vida, mais ela se sente angustiada e frustrada - assim o real é avaliado, do início ao fim do enredo, como sendo incompleto e insuficiente.

O que é preciso para completá-lo? Insuficiente em relação a quê? Ou para quem? Quer dizer, claramente há uma queixa em relação a algo que o real não possibilitou, não ofereceu, aquilo que então aparece como "falha": a realidade deveria ser digna e plena, mas não é. O que afinal seria uma realidade digna e plena? Uma ilusão, é claro, mas que neste caso está diretamente sobreposta ao real. E sendo a ilusão um modo de operar do imaginário, podemos dizer que incompletude e insuficiência são, no máximo, representações possíveis do real. Representações ilusórias, certamente, porque 
"medem" o real por meio de exigências a ele acrescentadas e cobradas, como as ideias de completude, plenitude e outras tantas. Em O princípio de crueldade, Rosset (2002) tece uma severa crítica das filosofias que consideram o real insuficiente por meio do ardiloso princípio de "realidade suficiente". Entre tais filosofias, o autor destaca as pseudotrágicas, como a de Lacan, que, à maneira kafkiana fala em nome de um "absurdo" (transposto no conceito de "Coisa") como premissa segundo a qual estamos todos condenados à incompletude - enunciado que pressupõe, assim como em Madame Bovary, uma queixa em relação ao que deveria ser, mas não é.

Com base nessa análise, podemos identificar um indício seguro da ilusão: o princípio de suficiência escondido, esperando para ser explorado, mas que justifica de antemão uma realidade insuficiente, absurda, alienada etc. O principal aspecto desse indício é sua imprecisão, isto é, sua incapacidade de ser visto diretamente, sua inaptidão de aparecer como imagem. Donde decorre que "o que há de impreciso no ilusório há de preciso no imaginário. Imaginário cujo lema poderia ser esta notável frase de Samuel Butler: I do not mind lying, but I hate inaccuracy — pouco me importa a mentira, mas detesto a imprecisão" (Rosset, 2006, p. 116). Com efeito, este critério da precisão ou imprecisão mostra-se bastante profícuo para compreendermos mais detalhadamente a relação de complementariedade entre real e imaginário.

Tomemos como exemplo uma cena no filme Cidade dos sonhos, de David Lynch (2001), na qual as protagonistas vão a um lugar chamado Clube Silencio - que por fora se assemelha a uma boate e por dentro é um teatro antigo. O homem que está no palco nos previne logo de início de que estaremos ouvindo uma música gravada de antemão, de que "não há banda e, não obstante, ouvimos a banda, é uma ilusão!". Enquanto soa um trompete, entra um homem tocando o instrumento; o músico abre os braços, afastando o trompete de sua boca, e o som permanece. Mesmo assim, as protagonistas Betty e Rita se emocionam e choram com o falso espetáculo. Com uma maquiagem carregada e um adorno em formato de lágrima colado na face, uma mulher entra no palco cantando uma música de imensa tristeza, proporcional à entrega da cantora que, de súbito, desmaia - mas seu canto permanece.

Ao contrário da recorrente desmistificação que mágicos famosos operam na TV, realizando um número de mágica para em seguida mostrar o funcionamento do aparato que torna a ilusão possível, no Clube Silencio a lógica de desmistificação é invertida: primeiro é revelado o truque e depois prevalece, como um encantamento que resiste à desmistificação, a resistência da aparência, que se mostra mais precisa do que a 
consciência da ilusão. Não significa que o real seja fantasioso ou inacessível, ou que haja algum princípio invisível de alienação sendo operado, mas apenas que a realidade é a própria aparência de si mesma. Qualquer critério para julgar qual realidade é mais ou menos verdadeira já nos coloca na posição imprecisa de árbitros do que deveria ser ou não a realidade. Muito mais preciso é reconhecer que o que temos são sempre aparências que podem servir tanto como fantasias que encobrem a realidade quanto como imagens e afetos que se integram a ela.

Essa forma de encarar a relação entre fantasia e realidade nos faz perceber também o engodo que é a promessa tecnocientífica de nos fazer penetrar numa realidade "mais real" - isto é, mais adequada a certas expectativas em relação ao real — do que aquela acessível pelos sentidos. Nas indústrias cirúrgica e pornográfica, por exemplo, anestesias e simulação de prazer sexual já alcançam um patamar de desempenho tal que a anulação da dor e a fruição do gozo não são provocadas nem por imagens/sons virtuais nem por estimulação/bloqueio dos sentidos, mas por uma intervenção neuronal direta, contornando inteiramente o nível da percepção.

O caminho impreciso seria concluir que esse tipo de procedimento gera experiências "artificiais" mais reais do que a realidade, isto é, necessariamente mais diretas e intensas por atuarem na parte de "dentro", não aparente, do nosso corpo. Talvez isso só pareça ocorrer, entretanto, justamente pela expectativa de que essa "nova realidade" possa vir a substituir a superfície imaginária do real — um cineasta como Hitchcock, por exemplo, temia que, no futuro, um filme de terror não teria que narrar um drama convincente, mas bastaria gerar as emoções adequadas a partir de um mecanismo ligado diretamente no cérebro do espectador. A suposta realidade mais real, portanto, começa a aparecer de maneira totalmente imprecisa, com traços notadamente metafísicos, como uma experiência que se pretende inteiramente descolada do imaginário e, por conseguinte, inassimilável. Com efeito, a maneira mais precisa de se assimilar essa "realidade mais real" não pode ser outra senão, novamente, a passagem pelas aparências, pela realidade sensível amparada no imaginário. Cabe aqui incluirmos um terceiro elemento: o "olhar" desde sempre imbricado no real e no imaginário, conforme o descreve Merleau-Ponty (1992, p. 128) em seu O visível e o invisível:

O visível à nossa volta parece repousar em si mesmo. É como se a visão se formasse em seu âmago ou como se houvesse entre ele e nós uma familiaridade tão estreita como a do mar e da praia. No entanto, não é 
possível que nos fundemos nele nem que ele penetre em nós, pois então a visão sumiria no momento de formar-se, com o desaparecimento ou do vidente ou do visível. Não há, portanto, coisas idênticas a si mesmas, que, em seguida, se oferecem a quem vê, não há um vidente, primeiramente vazio, que em seguida se abre para elas, mas sim algo de que não poderíamos aproximar-nos mais a não ser apalpando-o com o olhar, coisas que não poderíamos sonhar ver inteiramente nuas, porquanto o próprio olhar as envolve e as veste com sua carne. [...] Qual a razão por que, envolvendo-os, meu olhar não os esconde e, enfim, velando-os, os desvela?

Da perspectiva de Merleau-Ponty, importa-nos reter que não percebemos as coisas somente a partir do mundo, mas também a partir do olhar. Nosso olhar dota de sentido o mundo observado e, no mesmo movimento, percebe a si mesmo enquanto olhar. Este olhar nunca é estritamente subjetivo (não possui agência na coisa vista), bem como a percepção não é nem uma função sensorial e fisiológica, tampouco um fenômeno intuitivo e transcendente. A questão é que a forma de perceber prescreve tanto a coisa percebida quanto o olhar que a observa. Em outras palavras, retomando a metáfora que inicia este capítulo, cada indivíduo é como um peixe que não vê a água na qual está imerso. Essa água que nos circunda é o imaginário, uma grande rede de significados que organiza nossos modos de olhar. É sempre um agenciamento de imagens e sentidos que está em jogo no reconhecimento do real. Nas palavras de Rosset (2006, p. 111-112),

[...] temos boas razões para considerar que a estrutura do imaginário não difere fundamentalmente da estrutura do real e que, retomando uma expressão de Shakespeare em A Tempestade ('Somos feitos da mesma matéria que os sonhos'), a percepção do real e a representação imaginária são esculpidas na mesma matéria.

Até aqui espero ter esclarecido que imaginário e real não são a mesma coisa, mas tampouco se opõem, funcionando ambos em proveito de uma precisão da experiência sensível. O indício da imprecisão, por sua vez, confirma que a negação do real em que consiste toda ilusão está menos relacionada a uma "imaginação excessiva" do que, antes, a uma imaginação "precária". Seja como for, a relação entre real e imaginário pode ser assim definida: este dota de sentido aquele, que é sem sentido.

Não havendo sentido no real, desaprová-lo ou justificá-lo significa tentar sujeitar 
o real ao imaginário, isto é, a algum sentido qualquer - uma empreitada idealista. O pensamento trágico, ao contrário, se expressa pela "ligação entre a alegria de existir e o caráter trágico [sem sentido] da existência” (Rosset, 1989, p. 8). Tal afirmação de um trágico alegre não é contraditória, pois depende justamente da criação de valores - o embuste é quando esquecemos que todos os valores foram criados por nós e vemos neles algo de transcendente, de eterno e de verdadeiro. As possíveis decorrências de uma perspectiva trágica podem ser assim descritas: do caráter transitório e sem finalidade da vida deriva sua aprovação e afirmação; da relativização de todas as ordens (ideológica, científica, filosófica etc.) deriva o gosto pela ficção e pelo jogo das convenções; da falta de sentido de todas as coisas deriva a alegria de existir.

Claro está, pois, que o trágico nada tem a ver com uma inclinação pessimista por mais que conotações negativas sejam muitas vezes vinculadas ao termo "trágico": tristeza, sofrimento, obscuridade, implacabilidade, irracionalidade. Por isso convém enfatizar que, em suma, o que caracteriza o pensamento trágico não é apenas a constatação da falta de sentido do real, mas também a aprovação deste real em sua correlação com o imaginário. Daí que uma hermenêutica (teoria da interpretação), conforme argumento no capítulo 3, pode perfeitamente aliar-se a uma postura trágica, sobretudo numa abordagem educacional: para que, no lugar da esperança, da desesperança e de outras tantas ilusões, seja possível situar-se no mundo, compreendêlo, como também experimentar a intensidade da existência por meio da escolha de sua aprovação. Antes de avançarmos nessa direção, porém, parece-me pertinente pontuar algumas definições provisórias acerca do real e do imaginário. Não se trata, é claro, de uma demarcação extenuante, mas apenas de um recurso conceitual para organizar com maior clareza a fundamentação teórica delineada até aqui.

\subsection{DEFINIÇÃO PROVISÓRIA SOBRE O REAL: tudo, acaso e convenção}

Real é tudo que está aí, inclusive nossas ilusões e interpretações do real. O recurso de separar o real do que quer que seja é meramente intelectual e, não obstante, mal-intencionado uma vez que serve para justificar determinadas concepções, certas "verdades" que são desejadas enquanto tais. Assim como a falsa oposição entre natureza 
e artifício: tudo é natureza e, ao mesmo tempo, tudo é artifício. ${ }^{28}$ Tudo é real e, ao mesmo tempo, tudo é imaginário. Este somente se sobrepõe àquele caso se queira dissecar o real - e a quem interessa dissecar o real? Só se interessa por dissecar e regular o real quem não o aprova em todos os seus aspectos.

Se tudo o que percebemos, pensamos e sentimos já se insere no real, então já sabemos o que ele é - tudo o que está aí. O que não sabemos é o que ele não é, e qualquer tentativa regulatória de definir tal contraparte contradiz-se de imediato: tornase real ao ser meramente pensada. Mas faz sentido dizer que, se o real é tudo o que existe, seu oposto é o nada, aquilo que não tem existência — o que logo suscita a questão: mas se podemos nomear até o que não existe, então o "nada" também não seria um dos aspectos do real? Sem dúvida, o que reforça certa tautologia que se revela no vigor de um pensamento trágico: toda expressão que diga que uma coisa é uma coisa necessariamente passará por uma tradução do imaginário.

Dito isso, creio ser uma boa tradução para o real a conotação fornecida por Rogério de Almeida (2013) no que condiz às noções de "nada", "acaso" e "convenção" como expressões do trágico. Aproprio-me de tais noções para realocá-las no seguinte esquema: real como tudo, acaso e convenção; imaginário como nada, convenção e ficção - isto desde que ambos os registros sejam entendidos como coimplicados, nunca isolados nem isoláveis, e seus respectivos aspectos se interpenetrem, como num novelo de lã. Pois bem, vimos que o real é "tudo". E se tudo o que existe é somente o que existe, todo o resto é "nada", o que não deixa de ser um dos aspectos do real. Amor, valor, sentido, finalidade, necessidade, desejo - tudo isso concretiza nada, não expressa nada de real, mas é real à medida que nos afeta. São ficções humanas, procedem do imaginário, podendo tanto nos inserir quanto nos afastar do real — retomo tal oscilação a seguir, na definição provisória sobre o imaginário.

O que importa reter aqui é que o "nada" não é uma contraparte do real (que é tudo), mas expressa justamente o caráter trágico do real: o fato de, apesar de ser tudo, não significar nada. Nos termos de Rosset (2004), o real é insignificante, é idiotia (idiotès: simples, particular, único), o que não pode ser duplicado, o que é vivido num aqui e agora. Sendo ao mesmo tempo singular e plural, um e tudo, o real está indissociavelmente ligado ao acaso. É o acaso que gera os encontros (ou convenções, como argumento mais adiante) que tornam possível a existência, o real.

\footnotetext{
${ }^{28}$ A este respeito, cf. o ensaio "Artifício e natureza: a multiplicidade dos modos de existência", de Rogério de Almeida (2012b, p. 73-87), pautado na tese de doutorado de Rosset, "A antinatureza".
} 
Necessário pontuar a concepção de "acaso" a que me refiro: é o contrário da noção de que o presente seja o resultado de uma sucessão de fatos. Não se trata de negar as relações de causalidade: "Ninguém julgaria que uma mulher, supondo que caísse, caiu por causa do acaso. Caiu porque tropeçou, porque não viu a pedra. Mas a queda, a gravidade, a pedra ou a visão não são fundamentos, são o que são por acaso" (Almeida, 2015b, p. 97-98). Sob o viés trágico, pois, o acaso não é uma "exceção" da ordem, mas o contrário, a ordem como um esforço de compensar o acaso, sendo ela mesma derivada do acaso. ${ }^{29}$ Significa que, se não há no real um princípio dotado de intenção, propósito, lei, razão ou finalidade, a "ordem" das coisas é uma variação da desordem: "Entre as combinações possíveis para se gerar esta ou aquela condição existencial, algumas se realizam e permanecem, outras duram muito pouco, outras tantas sequer acontecem" (Almeida, ibidem, p. 56). Nestes termos, o acaso pode ser entendido como um mecanismo constitutivo da existência: são infinitas as possibilidades tanto de formas reais quanto de traduções imaginárias, mas a realização de cada possibilidade depende de encontros fortuitos, ${ }^{30}$ isto é, efetiva-se de acordo com ocasiões que acontecem "por acaso". Como explica Rosset (1989, p. 96),

\begin{abstract}
É raro que [o acaso] seja manifestado sob uma forma precisamente explícita; em filósofos como Montaigne, Pascal ou Nietzsche, onde ele desempenha um papel ao mesmo tempo fundamental e silencioso, não aparece quase nunca com todas as letras. Pode acontecer entretanto que intervenha de maneira explícita. É o caso, por exemplo, em Lucrécio, que atribui ao acaso a paternidade de toda organização, a ordem não sendo senão um caso particular de desordem. Imperialismo inerente ao conceito de acaso: produzindo tudo, o acaso produz também seu contrário que é a ordem (donde a existência, entre outros, de um certo mundo, esse que o homem conhece, e que caracteriza a estabilidade relativa de certas combinações).
\end{abstract}

Cada ocasião, portanto, "é a tessitura de tudo o que existe: é ela que produz as

\footnotetext{
${ }^{29}$ É neste sentido que Rémy Lestienne (2008, p. 91) argumenta, no âmbito do evolucionismo darwiniano, que "é o acaso que cria a ordem", pois o aspecto determinista das circunstâncias em nada contraria o acaso: "uma mutação é ao acaso na medida em que a chance de que ela aconteça não é afetada pelo fato de poder ser útil à sobrevivência da espécie" (ibidem, p. 88). As mutações proliferam-se ao acaso, embora algumas permaneçam em detrimento de outras, por meio de uma seleção posterior.

${ }^{30}$ Esta noção de encontros fortuitos remonta precisamente o conceito epicuriano de clinâmen: o desvio imprevisível de átomos que se chocam em nenhum lugar ou tempo fixo. Em Diferença e repetição, Deleuze (1988) emprega o termo em sua descrição de multiplicidades, sublinhando com isso a relação de "suposição recíproca" entre os átomos, isto é, a maneira retroativa pela qual os encontros são assimilados (diferença que há na repetição, o que é na cópia mais real que o próprio original).
} 
sensações singulares, jogos de encontros, localmente e temporalmente imprevisíveis" (Rosset, ibidem, p. 100-101). É o acaso que mantém o real em movimento, extraindo singularidade da multiplicidade - não sou o mesmo que fui ontem, tal qual o rio de Heráclito - , englobando assim a condição casual da existência: tudo é produto de encontros ao acaso. Incluindo encadeamentos causais? Certamente que sim, com o adendo de que as relações de anterioridade ou de sucessão são de ordem imaginária, conforme explicita Rogério de Almeida (2015b, p. 98):

Quando olhado de trás para frente, o universo parece uma sucessão ímpar de encadeamentos, como se houvesse uma lógica inconcebivelmente inteligente para ordenar essas causas-consequências-causas. Mas se formos ao antes desse nascimento (como se isso fosse possível!), talvez veríamos uma sucessão de erros, acontecimentos sem consequências, explosões sem vida. Em uma palavra, uma realidade feita de acasos.

Se o universo, se o mundo, se a vida, se o real, se minha subjetividade, se tudo o que há tem como princípio o acaso, e se o acaso não se define, então temos que o princípio de tudo é a ausência de princípio, ausência de necessidade, de vontade, de inteligência, de força, de natureza. O que é veio a ser da mesma forma que poderia não ter vindo. Se é, é por acaso e não por fundamento.

Essa definição breve de acaso, em que ele é o fundamento do que não se fundamenta, para além do paradoxo, expressa o trágico da existência e, por extensão, do real.

Avançando em nossa digressão acerca do real, "o pensamento do acaso é assim conduzido a eliminar a ideia de natureza e a substituí-la pela noção de convenção. O que existe é de ordem não natural, mas convencional - em todos os sentidos da palavra" (Rosset, 1989, p. 101). Se não há ordem, vontade ou qualquer princípio que possa reger o real, então o real é sempre acidente, aparência, convenção, sem mistério ou sentido oculto que nos impeça de (re)convencioná-lo - " "as leis da natureza são de uma ordem exatamente tão institucional quanto as leis estabelecidas pela sociedade: elas não são provenientes de uma imaginária necessidade, mas tiveram, também elas, que se instituir graças às circunstâncias, exatamente como as leis sociais" (idem).

Deste modo, podemos falar em duas "modalidades" de convenção, ainda que tais 
modalidades não se distingam senão no imaginário. De um acaso "natural", convenção implica o encontro de moléculas, de átomos, formação de coisas que existem. De um acaso "social", convenção implica formação de instituições, hábitos, costumes, culturas. É o que sinaliza Rosset (1989, p. 101), ao estabelecer que:

\footnotetext{
Convenção designa, com efeito, em um nível elementar, o simples fato do encontro (congregações que resultam em 'naturezas' mineral, vegetal ou outra; encontros que tornam possíveis as 'sensações'). Em um nível mais complexo, de ordem humana e mais especificamente social, convenção toma sua significação derivada, de ordem institucional ou costumeira (contribuição do acaso humano ao acaso do resto 'do que existe').
}

De um modo ou de outro, o próprio real é produto de uma convenção do acaso, convenção à qual acrescentamos outras, imaginariamente, portanto podendo ou não culminar na ilusão, como é o caso de certas narrativas sociais que buscam um fundamento transcendente para uma concepção ilusória do real. Logo, mesmo a ficção pode ser entendida como uma modalidade de convenção (imaginária), sendo a ilusão, por sua vez, uma forma de ficção que visa "regular" o acesso ao real: quando eu tomo do real só a parte que tolero, a que me é agradável, suprimindo o que é desagradável. Como vimos, enfim, a ilusão é apenas um artifício imaginário que, justamente por tentar negar ou aprimorar o real, serve como contraponto para uma descrição do real, cujos aspectos também se tornam mais claros em relação ao imaginário que o complementa. Por ora, retenhamos a seguinte definição provisória: real é tudo o que existe, constituise pela força do acaso e é produto de encontros ao acaso, convenções.

Antes de avançarmos para uma definição sobre o imaginário, é pertinente explanar sobre aquilo que poderia ser lido como "ponto cego" em meus argumentos: o real não possui sentido inerente (mas tal afirmação não lhe atribui um sentido inerente?) e instaura-se por força do acaso (uma ausência de causa que atua como "causa" do real?). Se em momento algum tais pressupostos foram justificados, é porque qualquer justificativa implicaria negá-los. Em primeiro lugar, justificar a ausência de sentido seria dotá-la de algum tipo de sentido, de alguma convenção - como, por exemplo, o nonsense, cujo sentido é (justifica-se por) não fazer sentido. Logo, a ausência de sentido do real, sob o prisma trágico, não se justifica senão de maneira "acrescentada", isto é, sem propriamente justificar nada. 
[...] não é a oscilação dos sentimentos e/ou da razão que faz com que o real fique sem sentido. É a própria noção de sentido que é estranha ao real. Isto é: o real é o que é, desprovido, portanto, de sentido ou de alguma falta (a falta de sentido, por exemplo). Dessa forma, quando é dito que não há sentido no real, deve-se entender que ele é completo em sua insignificância, ou seja, não carece de nada. Daí a impossibilidade de se operar com os conceitos de absurdo e de nonsense [...] (Almeida, 2015b, p. 96).

Do mesmo modo que David Hume não demonstrou a inexistência da causalidade, mas assinalou um "nada" lá onde se procura a ideia de uma causa, digo que o real não tem sentido porque a exigência de sentido ocorre por "efeito" (humano, imaginário) do real, não como causa/necessidade. Por sua vez, "o acaso não é mostrável porque a necessidade não é nunca mostrada" (Rosset, 1989, p. 136).

Assim como a necessidade, o acaso que se lhe opõe não pode ser "mostrado" tampouco demonstrado, a não ser em nome de uma causa qualquer; mas o acaso é precisamente a recusa de toda ideia de causa ou necessidade. Um acaso assim imanente, ${ }^{31}$ afirmado sem demonstração - isto é, sem exposição das razões que o tornariam, para o intelecto, uma verdade "necessária" - pode ser encontrado precisamente na Ética de Spinoza (2007), paradoxalmente em sua premissa da onipotência da necessidade. O "ponto cego" spinozista consiste na demonstração rigorosa de uma necessidade não demonstrável: Deus como sendo a única substância a existir na natureza. Explica-nos Rosset (1989, p. 134-135):

A afirmação de uma necessidade, a partir da qual tudo seria necessário (e a
partir do que a Ética [de Spinoza] põe efetivamente em marcha uma rede de
deduções necessárias), é ela mesma privada de cada uma das características
da necessidade. O grande paradoxo do pensamento spinozista está aqui: o que
distribui a necessidade (o deus sive natura, ou ainda, a soma "do que existe")
não possui, ele mesmo, a necessidade. Paradoxo de um rio de torrente
inesgotável, mas sem nascente. Tudo se demonstra a partir da necessidade, e
nada demonstra a necessidade [...], tudo pode e deve colocar-se a partir "do
que existe", sem recurso metafísico a uma ideia de fundamento necessário. A
afirmação spinozista da necessidade aparece então finalmente como
exatamente equivalente à afirmação do acaso: sendo a definição da

31 "O plano de imanência não é um conceito pensado nem pensável, mas a imagem do pensamento, a imagem que ele se dá do que significa pensar, fazer uso do pensamento, se orientar no pensamento" (Deleuze; Guattari, 1992, p. 53). 
necessidade segundo a Ética que nada, sem exceção, é necessário — que tudo se pode interpretar sem recorrer a uma ideia metafísica, teológica ou antropológica da necessidade. Aqui aparece a chave do paradoxo spinozista: Spinoza afirma a necessidade, mas depois de tê-la privado de todos os atributos cujo conjunto contribui para dar um sentido filosófico à noção de necessidade. Assim privada da referência antropológica, finalista, metafísica, a necessidade torna-se, em Spinoza, um branco, uma falta a pensar, exatamente do mesmo modo que o acaso.

Spinoza afirma o acaso pelo fato de que a necessidade é dada de saída como um objeto de afirmação, não de demonstração nem de justificação. O que faço aqui é apenas tomar o atalho de considerar o acaso como necessário. Alguém ainda poderia objetar que, mesmo não sendo possível demonstrar a necessidade do acaso, eu poderia ao menos "provar" a existência de "algum" acaso. Nesse caso, recorro novamente a Rosset (ibidem, p. 135): “o pensador do acaso [...] dirá em termos jurídicos que num semelhante processo é ao pensador da necessidade, e não a ele, que cabe a responsabilidade da prova". Não se pode provar o contrário daquilo que igualmente não se prova. O que eu chamo de acaso é, com efeito, a soma dos "nadas" que aparecem a cada vez que se faz alusão à necessidade. Daí a antinomia que há entre acaso e necessidade, bem como entre aprovação e justificação: “Aprovar é negar que 'o que existe' deva ser justificado com razão: sendo uma tal justificação negadora em potência (por não aprovar senão sob condição de justificação)" (ibidem, p. 137).

\subsection{DEFINIÇÃO PROVISÓRIA SOBRE O IMAGINÁRIO: nada, convenção e} ficção

Se há pouco propus que "tudo é real", o que dizer das imagens? Ora, toda imagem é real enquanto imagem, mas é também imaginária por propor uma fabulação, um sentido para o real. Por que o sentido não seria real, se é por meio dele que nos instauramos no espaço tangível do mundo? Um átomo seria mais ou menos real? $\mathrm{O}$ radar do morcego seria mais ou menos real? Quer dizer, os recursos todos que os organismos reais dispõem de perceber a realidade não são reais? O que se transpõe à questão: haveria diferença entre o real de fato e o real percebido como real? Não é difícil notar como todas essas separações apenas sobrepõem camadas e mais camadas de 
distanciamento do real, sem, de fato, alterar em nada a concepção metafísicoiconoclasta tradicional. Enfim, vale reiterar o que já argumentei até aqui: separar ou medir "mais real" e "menos real" é um recurso imaginário e, via de regra, ilusório.

Sendo assim, o que podemos dizer do imaginário que o diferencie do real? Imaginário é o registro dos sentidos, dos valores, das formas e das convenções: no encontro entre o real (destituído de inteligência, vontade, razão, sentido etc.) e o homem (constituído de todas essas faculdades), o imaginário aparece como espaço humano que possibilita o desenvolvimento da cultura, como convenção e invenção. ${ }^{32}$ É o imaginário, não o real, que cria conceitos, traduz objetos, estipula leis e produz lógicas diversas. Se o real se caracteriza pela falta de sentido, tudo que possui sentido diz respeito ao imaginário, incluindo as explicações sobre o real e o imaginário. Nesses termos, o homem, o real e a existência só poderiam ser entendidos como, por exemplo, "contraditórios" em relação a constructos imaginários (como a noção de coerência) e mediante a prevalência de convenções sociais. Tanto coerência quanto contradição são indícios do imaginário, que persiste em produzir sentido.

Tal funcionamento ilustra um primeiro aspecto do imaginário: mesmo quando ele parece contrariar o acaso (por meio de ideias como necessidade, causa, finalidade etc.), não o faz. Porque, de um lado, o imaginário é ele próprio fruto do acaso e, de outro, o acaso também pode ser "pensado" - enquanto conceito, o acaso depende mais da imaginação do que de qualquer outra faculdade. É pertinente salientar que o acaso não anula a possibilidade de causalidade (esta também procede do acaso), pois ele está na origem de todas as possibilidades. O que vem a existir pode responder a uma ordem — a chuva cai por causa da força gravitacional —, mas essa ordem está subordinada a um modus operandi originado a partir do acaso. Com isso podemos entender que, se o imaginário não se opõe ao real, tampouco se opõe ao acaso. O imaginário não á capaz de alterar o acaso, mas existe independentemente de reconhecê-lo ou de tentar negá-lo.

Daí que a ideia de "nada" expressa apenas um imaginário trágico (não todo tipo de imaginário), a começar pela constatação de que os sentidos propostos pelo imaginário são nada. Ora, se a argumentação aqui construída já está alinhada, desde o início, a um imaginário trágico, creio estar "liberado" para incluir o nada entre os aspectos do imaginário. Como vimos, o nada também expressa o caráter trágico do real:

32 "Toda expressão dotada de significado, e portanto toda experiência e todo entendimento, é uma espécie de invenção, e a invenção requer uma base de comunicação em convenções compartilhadas para que faça sentido - isto é, para que possamos referir a outros, e ao mundo de significado que compartilhamos com eles, o que fazemos, dizemos e sentimos" (Wagner, 2010, p. 76). 
o fato de este ser insignificante, pois todo sentido é dado imaginariamente. Não é que o real seja incompleto ou insuficiente (em relação a quê?), como o são todos os recursos que temos para percebê-lo. É que, para não o perder de vista, colocamos o real em perspectiva, dando-lhe uma carapuça, recobrindo-o com uma ficção. E por que o perderíamos de vista?

Porque, perante o real, nossa consciência atina para o nada que éramos antes de existirmos e ao nada que voltaremos a ser. Afinal, já havia real antes de nascermos e continuará havendo após deixarmos de existir. Por isso que o "nada" refere-se menos ao real e mais ao valor imaginário que damos a ele. Qual o valor disto ou daquilo? Qual o significado disto ou daquilo? Sob a ótica de um imaginário trágico, não há parâmetros, não há referencial, há somente correspondências imaginárias que nada valem. Se qualquer coisa pode valer qualquer outra coisa, ambas as coisas não valem nada, de modo que não há, no real, qualquer diferença de valor que não seja imaginada.

\footnotetext{
A visão trágica, que pode se dar, por exemplo, na constatação da finitude e do tempo que passa, exige do homem uma posição (adesão a um imaginário) que o ajude a se situar num mundo que, sem esse imaginário, se apresentaria de maneira insuportavelmente hostil. Assim, é o imaginário que permite ao homem dotar o mundo de sentido, organizá-lo em imagens, discursos, narrativas, pensamentos, instaurar uma cultura que sobreviva à curta duração de uma vida e possa ser legada às gerações futuras.
}

Operando tanto como princípio de inteligibilidade quanto organização da experiência sensível, o imaginário, dependendo da adesão ou da crença que se tenha em determinada convenção, poderá pender tanto para uma visão trágica como para uma alternativa ilusória (Almeida, 2015b, p. 74).

É em relação ao imaginário, pois, que o real impõe-nos uma difícil escolha: aprovar uma existência sem princípio ou finalidade que não de ordem imaginária e convencional (escolha trágica), ou, não suportando tal visão, valer-se de uma ilusão qualquer que "eufemize" tal existência por meio de um sentido consolador (escolha não trágica). De um lado, o imaginário trágico; de outro, o ilusório. Só que mesmo "a tentativa de escapar de uma realidade que se desaprova por meio de uma eufemização imaginária conduz justamente a essa mesma realidade (que é, aliás, a única existente)" (ibidem, p. 75-76). Assim, o que está em jogo na valoração do real é necessariamente nada, que é afirmado pelo imaginário trágico e negado pelo imaginário ilusório. Tal 
ideia de "nada" aproxima-se da noção de "silêncio" descrita por Rosset (1989, p. 65) como "o que deixa mudo todo discurso, o que se furta a toda tentativa de interpretação", o que também define uma condição de existência:

[...] o que resta, além disso, parar ornar o ser, uma vez excluídos da existência todos os seres designados pelas palavras? Existe "alguma coisa", mas essa alguma coisa não é nada, sem nenhuma exceção, do que figura em todos os dicionários presentes, passados e por vir. "O que existe" é, pois, muito precisamente, nada. Nada, isto é: nenhum dos seres concebidos e concebíveis; nenhum dos seres recenseados até esse dia figura no registro do que o pensamento do acaso admite a título de existência (ibidem, p. 103).

Mesmo que essa conceituação, vale dizer, seja propriamente conceitual, é produto do imaginário, só que sob uma orientação trágica. Rosset ainda recorre à figura de Ulisses, tal como a descreve Homero, como representação deste "nada" que vigora no real: ao recusar-se portar um nome (“meu nome é ninguém”), Ulisses mantém-se vitorioso, até porque Ulisses vencido significaria nada vencido, ninguém derrotado. Do mesmo modo, o real permanece inapreensível e irrefutável, privilegiando assim não o "ser", mas sempre o "parecer". Em outros termos, recorrendo agora ao pensamento sofista, nada que possa ser concebido como "ser" participa da existência.

É isso que postula Górgias em seu Tratado do não-ser ou da natureza, título este que, de acordo com Rosset (idem), poderia ser invertido sem danos: "tratado da natureza, ou do não-ser" - sendo, então, de ordem imaginária a noção de "natureza", como sustentarão mais tarde Lucrécio e Montaigne. ${ }^{33} \mathrm{O}$ tratado de Górgias pode ser assim resumido: nada é; mesmo que alguma coisa possa existir, essa coisa é incognoscível ao homem; mesmo que alguma coisa existente seja cognoscível, ela não é comunicável ou explicável aos outros. ${ }^{34}$ Tal estratégia sofista, tão combatida por Platão, nada pretende provar, a não ser o caráter inventivo do pensamento - uma "fabricação

\footnotetext{
${ }^{33}$ Lucrécio destina seu De rerum natura a demonstrar que não há "natureza das coisas" (cf. Rosset, 1989, p. 137-159). Por sua vez, em seus Ensaios, Montaigne (2000, tomo II, 12, p. 403) afirma que o ser não pode ser outra coisa senão uma "obscura aparência e sombra, e uma incerta e débil opinião". Convém acrescentar o postulado de Alberto Caeiro - heterônimo de Fernando Pessoa (1981) - segundo o qual não existe natureza, ao menos não como conjunto real e verdadeiro, mas somente como "partes sem um todo".

${ }^{34}$ Segundo Giorgio Colli (1992, p. 73), Górgias teria fundado a arte retórica em detrimento da dialética clássica: "Qualquer juízo, em cuja verdade acredite o homem, pode ser refutado". Se primeiro alguém demonstra que uma proposição é verdadeira, e a seguir outro alguém demonstra como verdadeira uma proposição que contradiz a primeira, então ambas as proposições são verdadeiras e falsas ao mesmo tempo, o que é impossível. Eis a premissa de Górgias: "Essa impossibilidade significa que nenhuma das proposições indica algo de real, e tampouco um objeto pensável" (idem).
} 
poética”, conforme Górgias explicita em seu Elogio à Helena - e, portanto, a íntima ligação entre real e imaginário mediante um olhar fadado a criar sentido para si e para o que enxerga. Um olhar, porém, que não deixa de reconhecer (aprovando ou denegando) um mundo desprovido de sentido, porque é sempre no enfrentamento de um mundo não traduzível que conseguimos traduzi-lo, acessá-lo e habitá-lo. Em suma, o real é expresso pelo imaginário, em cujo tecido de imagens e sentidos redescobrimos a possibilidade de revigorar olhos novos para um mesmo nada.

Pontuemos agora o segundo aspecto do imaginário: a convenção — que, diferente do "nada", abrange todo tipo de imaginário. Vimos que, de um lado, temos um reino "à parte", o do imaginário (representações, convenções, conhecimento etc.), que estabelece uma gramática para traduzir o real; de outro, mesmo traduzido e retraduzido, o real permanece intraduzível, isto é, sempre sem um sentido além de ser ele mesmo. Uma árvore será sempre "árvore" (imaginário), mas uma árvore nunca é a mesma que outra (real). Nada há entre uma coisa e outra que não seja construído, estruturado, formalizado e ritualizado socialmente sob a forma de convenção.

Se o próprio real pode ser entendido como convenção (no sentido de encontro, produto do acaso), e se o imaginário é inseparável do real, então as convenções imaginárias, mesmo quando avessas às convenções do acaso, não deixam de ser reais: o imaginário circunscreve símbolos em teias, em constelações, em determinados sentidos, isto é, encontros, convenções.

\footnotetext{
Esses símbolos tendem a se organizar em discursos, em narrativas, como as que se encontram na pintura, no poema, nas palavras de ordem, num conjunto de leis, em uma melodia musical; e essa narrativa, para além de seu sentido concreto, imediato, conformado pelas contingências socioculturais ou biográficas, guarda um sentido figurado, simbólico, identificável através do reconhecimento das metáforas, das unidades significantes que constituem uma redundância simbólica. (Almeida, 2014, p. 71-72)
}

A convenção atua então como uma espécie de "função" que mantém o real e o imaginário ora interligados ora separados (no caso de uma convenção ilusória, isto é, que queira sobrepor-se às convenções do acaso). É nas convenções sociais, por conseguinte, que se revelam mais visivelmente as ficções, outra expressão do imaginário: na expectativa de ascender socialmente, na esperança de superar dificuldades, nas reinvindicações, nas promessas, nos compromissos etc. Em suma, o 
imaginário joga com o real por meio de convenções, as quais se apresentam, por vezes, por meio da ficção — entendida, portanto, como uma modalidade da convenção (diferente da língua ou de um encontro de átomos, por exemplo).

Sob um viés trágico, segundo o qual nossa consciência atina para o nada, acionando assim o imaginário que irá organizar nossa compreensão do mundo e de nós mesmos, podemos localizar a convenção num ciclo de repetição: o nada que sempre reaparece e a convenção que sempre o reorganiza. Para compreendermos a dinâmica que movimenta esse ciclo, poderíamos recorrer a Gilbert Durand (1997) que, em As estruturas antropológicas do imaginário, fala em termos de uma "angústia existencial" (constatação de finitude e do tempo que passa) que aciona as estruturas do imaginário. ${ }^{35}$ Entretanto, creio ser mais fácil enxergarmos de outro ângulo: ao imaginário cabe menos alterar o real do que, antes, fazê-lo "falar" por meio de algum sentido. Quando despertamos, por exemplo, pouco antes do grande desfecho de um sonho, fechamos os olhos novamente e tentamos a todo custo voltar para o mesmo sonho. Tudo em vão, claro, restando-nos apenas a possibilidade de inventar, preencher os espaços vazios, dar uma continuidade ficcional para a ficção que vivemos no sonho.

Algo similar acontece quando ficamos de luto. Um processo básico para lidar com tal descontinuidade é a "eufemização" da morte: desde os rituais funerários mais antigos, vemos a preparação do corpo para uma viagem de transição, como se nosso cuidado com o morto pudesse garantir sua passagem a outro plano. Ou seja, na tentativa de reduzir, ao menos simbolicamente, o impacto do nada e do acaso que a todos acomete, escoramo-nos numa ficção que reorganiza mais uma vez nossa atualidade no mundo. Sob um panorama mais amplo, podemos dizer que a sociedade é regida por convenções que, por mais que se alterem, são incapazes de modificar o nada ("imunidade" do real que continua sem sentido) e o acaso (cuja mudança constitutiva não muda). No entanto, são as convenções que provocam uma diferença na repetição do nada e do acaso - diferença não constitutiva, literal, mas interpretativa.

Coloquemos da seguinte maneira: convenção imaginária é tradução de um contexto, tradução esta formada pelas sucessões de olhares e partilhada pelas opiniões. Certamente é uma dimensão fictícia (ilusória ou não), por meio da qual nos situamos no real, atribuindo alguma interpretação às coisas e a nós mesmos. Disso resulta uma

\footnotetext{
${ }^{35}$ Embora Durand não se detenha extensamente sobre esse aspecto, toma-o como um ponto de partida para o imaginário, assim como Edgar Morin, que localiza na consciência da morte e do tempo a origem dos processos de simbolização inerentes às culturas humanas. Cf. Morin, 1973.
} 
diferença na recorrência do acaso que se repete, diferença esta que não se sobrepõe a tal repetição, apenas acrescenta mais acaso ao acaso que já existe, engendrando assim um sentimento, uma narrativa, uma ficção.

Eis o aspecto convencional do imaginário: as traduções sempre se desdobram de outras, como numa cebola cujas camadas, se retiradas, nada escondem. Em outros termos, os significados só existem e só deixam de existir à medida que os traduzimos um pelo outro. Mesmo as noções de real e imaginário, bem como as convenções que os expressam, conformam uma tradução (caracterizada aqui como trágica) entre outras tantas possíveis - como a que definimos como não-trágica ou ilusória, que busca estabelecer e estabilizar um princípio qualquer que sirva como premissa, comprovante ou amparo que recuse o acaso.

É possível ser de outro modo? Quer dizer, o que resta quando se deterioram todos os chãos, toda crença ou tradução imaginária? Nada, por certo, mas um nada positivamente "recuperado": ao suprimirmos o que numa convenção já se apagou, o acaso (que é tudo) solicita-nos novas coordenadas imaginárias. Em todo caso, o real permanece intraduzível, o nada sempre reaparece e, com ele, o acaso "aciona" o imaginário. A questão é sempre a mesma (o real), as respostas é que mudam. De um lado, o real é singular: cada coisa/ocasião é única, não pode ser duplicada, não havendo tampouco original e cópia (tudo é aparência), já que somente um construto racional pode julgar semelhanças e diferenças. De outro, o real torna-se plural por meio do imaginário: cada ideia imaginária não interfere nas coisas que traduz, podendo fazer sentido apenas pela enumeração plural de cada existência singular.

Daí que um imaginário trágico, para manter-se entrelaçado ao real, tende a atuar como tautologia do real, isto é, confirmando a identidade de uma coisa consigo mesma: o mundo é o mundo. Para assimilarmos com acuidade este aspecto tautológico, que se mostra relevante no decorrer desta tese, talvez seja útil criticarmos a acepção de Wittgenstein acerca desse termo. Em seu Tractatus logico-philosophicus, o filósofo da linguagem considera toda tautologia uma expressão vazia de sentido, porque "um único que é idêntico consigo mesmo por certo não diz nada" (Wittgenstein, 1968, p. 106). Em outros momentos do mesmo Tractatus, o autor argumenta que, ao abranger todas as situações possíveis, a tautologia não representa nenhuma situação possível e, sendo verdadeira sob qualquer condição, ela não possui condições de ser verdadeira. Esta contradição que Wittgenstein atribui à tautologia, no entanto, somente faz sentido sob o prisma de um imaginário lógico, de modo a colocar a própria linguagem como uma 
barreira contra o real (irredutível à lógica).

Em seu livro sobre esse tema, Rosset (1997) argumenta que, enquanto a metafísica nos arremessa para um além da realidade, a tautologia wittgensteiniana nos seguraria num aquém para sempre intransponível, isto é, num solipsismo segundo o qual "os limites de minha linguagem denotam os limites de meu mundo" (Wittgenstein, 1968, p. 111). Haveria uma sutil diferença se, em vez disso, disséssemos: a definição do mundo sempre se limitará aos meios atuais que tenho para defini-lo. Nesse caso, a tautologia não apenas é incontornável (o que seria esta ocasião senão esta ocasião?), como também passa a direcionar ao real a atuação do imaginário. Em vez de dizer que é impossível traduzir o mundo por outro nome que não seja "mundo", agora dizemos que é impossível substituir o mundo por qualquer outra coisa.

Assim, um imaginário trágico afirma o acaso, seguindo o raciocínio de Rosset (1997, p. 33), por meio da tautologia: em vez da fórmula "A=A", na qual dois termos devem coincidir (esta árvore é igual àquela), tautologia corresponde à fórmula "A é A", ou seja, uma coisa é somente ela mesma, nunca outra coisa. Com efeito, não se trata mais de uma relação lógica, trata-se de uma precisão expressiva que, como demonstrei anteriormente, mantém em sintonia real e imaginário. Por conseguinte, se é o acaso que nos solicita uma relação precisa com cada ocasião, isto é, sem perder o real de vista, então é preciso haver uma dinâmica tautológica por parte do imaginário.

Afinal, que algo a mais poderia haver além de aparências conforme cada ocasião? Absolutamente nada, de modo que qualquer indício de insuficiência que possamos ver nas coisas reside menos nas coisas e mais em nossas tentativas de assimilá-las, traduzi-las e expressá-las. Compreender ou expressar aquilo que não poderia ser outra coisa demanda um esforço de reorganizar os referenciais que temos para compreendê-lo ou expressá-lo. Assim, o imaginário permanece em jogo, como uma aposta contínua cujas cartas mudam a cada instante, conforme o acaso que as coloca sobre a mesa. O que se aposta evidentemente não é o real (que nunca precisou de significado algum), muito menos os significados que a ele atribuímos, mas a aprovação de um mundo que se introduz nas variações de sentido que nossas linguagens fracassam em estabilizar. É nesse sentido que, para Rosset (2000, p. 29), só pode haver alegria caso esta não se justifique de maneira racional, mas que se sustente de maneira precisa numa aprovação incondicional do que a cada momento nos é dado a viver.

Pois bem, resta-nos atentar um pouco mais à ideia de ficção. A tradução pela qual percebemos o mundo - nossas experiências imediatas movimentam-se mediante 
operações do imaginário - exerce certa função fabuladora não tanto de coincidir com o real, mas antes de incidir em nossa relação com ele. Tal incidência pode tanto afirmar o real (ficção trágica) quanto negá-lo ou condicioná-lo a uma convenção qualquer (ficção não-trágica). Em todo caso, as ficções são imaginárias e, portanto, tendem a atribuir ao real uma roupagem que não lhe é inerente. Mas é delas que tomamos referenciais para compor uma ficção de nós mesmos, e esta é a pertinência deste conceito neste trabalho: ficção como modalidade de convenção imaginária que possibilita uma relação hermenêutica entre nós e o mundo. É como se nossas ficções particulares fossem, a nível micro, aquilo que as convenções sociais são a nível macro.

O conto "Ideias do canário", de Machado de Assis (2008), é bastante ilustrativo para compreendermos esta "apropriação" ficcional, além de retomar a dinâmica tautológica do imaginário trágico que expusemos há pouco. Trata-se de um diálogo anedótico entre Macedo, um homem "dado a estudos de ornitologia”, e um canário que ele encontra numa loja de belchior. Em três momentos diferentes, Macedo coloca a mesma questão ao canário: o que é o mundo?

Primeiro, o canário diz que o mundo é a loja de belchior e que tudo o mais é ilusão e mentira. Na segunda vez, após ter sido instalado no jardim da casa do Macedo, o canário diz que o mundo é o jardim e que tudo o mais é ilusão e mentira. Por fim, depois de ter fugido da gaiola, o canário afirma que o mundo é o céu azul e que tudo o mais é ilusão e mentira. Em suma, o canário descreve o mundo de maneira tautológica, definindo-o precisamente por aquilo que ele vê, de modo que, quando o pássaro muda de ambiente, sua definição de mundo acompanha seu olhar. Ora, o humor do conto está na tautologia que inviabiliza a expectativa de Macedo em querer encontrar alguma explicação constante, isto é, alguma ordem conceitual qualquer.

O que é constante, contudo, é uma dinâmica de tradução: só existe aparência, tudo o mais é ilusão e mentira. Para Macedo, assim como para Wittgenstein, isso não diz nada - claro, porque se espera que isso diga outra coisa. Em todo caso, é como se o canário preferisse aderir não a uma conjuntura qualquer, mas sempre à convenção de cada lugar em que ele passa a estar. Dessa maneira, sua ficção particular é construída apenas a partir da ocasião, pois qualquer ordem não interfere no que é. Mesmo as convenções, numa dimensão mais ampla, também se alteram conforme ocasiões - e é justamente esta sincronia com o acaso que promove força e precisão a uma ficção (particular ou coletiva). Precisão por não estar alheia à circulação dos bens simbólicos que perfazem a cultura, apropriando-se dos elementos disponíveis para compreender o 
mundo. Força porque, com a adesão às convenções, ganha valor e contexto uma narração de si, ficção esta que nos leva a compreender o mundo e, nele, também a nós mesmos.

Sob esse viés, fica evidente como mesmo a experiência estética é inseparável das convenções - ou seja, o contrário do que um autor como Pierre Bourdieu (2007), por exemplo, defende em seu livro A distinção. A noção reducionista de Bourdieu de que o "gosto", sendo parte do habitus, nada mais é do que a incorporação inconsciente de certos modos de ser que caracterizam uma classe social, suscita-nos de imediato a questão: para que construir todo um aparato conceitual quando se trata de reduzir todas as convenções ("gostos”) a relações de dominação camufladas? Afinal, esta própria desconfiança de que nada escapa dos jogos de dominação não seria a maior e mais desgastada convenção de todas? Seja como for, é preciso não perder de vista o fato de que toda desmistificação das convenções recairá, via de regra, numa outra convenção.

Um mundo como aparência de si, traduzido por sentidos "acrescentados" e que não deixa de ser este "nada" de singularidades breves, é o único mundo que existe e, portanto, o único que pode ser habitado. Não há o que se ver por trás das coisas vistas, tampouco há lugar para ideias de permanência e estabilidade se, para dar conta do fluxo vivido, é preciso estar em consonância com ele, isto é, vivendo-o. Com isso, é possível notar que a ficção não apenas pode conduzir num mesmo "compasso" real e imaginário, mas também depende, ela mesma, desse compasso para se constituir como percurso (hermenêutico). Poderíamos ainda dizer que, sob o viés da ficção, o próprio agenciamento entre real e imaginário importa menos do que o modo como escolhemos tratar tal agenciamento: se escolhemos aprovar o real, vivendo-o conforme a ocasião, ou se preferimos rechaçá-lo em prol de uma ilusão qualquer.

Não se trata, convém pontuar, de uma reprodução ou submissão ao real, e sim de um jogo de possibilidades narrativas que não concorram (por substituição ou regulação) com o real, podendo ser tais possibilidades mais ou menos realistas, mais ou menos fantasiosas, mais ou menos críveis ou incríveis - como no já mencionado caso de Dom Quixote. A questão é que, tal como em relação a um filme, nunca agimos passivamente em relação a uma ficção, mas participamos dela, numa inserção que incide menos na ficção em si e mais em nossa relação com o mundo - lembremos aqui como Gil, protagonista de Meia-noite em Paris, de Woody Allen, aprende a escolher e aprovar o presente por meio de sua fantasia sobre o passado. Com efeito, é sempre no mundo vivido que a ficção está ancorada, e será somente nele que ela voltará a calhar, seja de 
maneira ilusória ou não. Trata-se da mesma premissa sublinhada por Rogério de Almeida (2012a, p. 50) em sua análise de Meia-noite em Paris:

[...] parece ser esta a principal função da ficção, ou ao menos sua possibilidade formativa ou mesmo educacional: propor outras realidades, não como alternativa (ideológica, metafísica ou de qualquer outra ordem) a esta realidade aqui - que ao cabo é a única que existe - , mas como possibilidade de compreendermos a própria realidade, de nos situarmos nela, de aprová-la, pois, em última instância, é a única que temos.

Evidentemente, qualquer ficção pode tornar-se ilusória ao configurar, para quem a vivencia, uma forma de desaprovação do real. Em contrapartida, por meio de certo movimento tautológico, uma ficção pode pôr em evidência o que já está em evidência, logrando assim em dar sentido e expressividade ao mundo, ao que se abre ao acaso, à ocasião que não se pode mudar, retocar ou substituir — o que não a impede de ser interpretada, conjugada em ficção. Desta feita, podemos finalmente estabelecer uma definição provisória do imaginário e, ainda, antecipar a importância da ficção na abordagem hermenêutica da qual se trata o capítulo seguinte.

Imaginário é nada por ser avesso ao acaso, compondo sentidos que organizam o real e que, em última análise, não expressam nada de real. Ao mesmo tempo, o imaginário faz constelar determinados sentidos e, portanto, promove encontros imaginários, convenções imaginárias (em oposição às convenções do acaso) que, por sua vez, se expressam, entre outras coisas, por meio da ficção - mas também por meio da lógica, da língua, da metáfora, dos "gostos" etc.

Sob um viés hermenêutico, a ficção mostra-se importante mediante o seguinte raciocínio: se o mundo pode ser visto, sentido e vivido, também pode ser interpretado. O que implica expressá-lo, (re)apresentá-lo, narrá-lo para compreender não tanto o mundo em si, mas o sentido que o "faz falar", ou seja, nossa relação com este mundo "compreender a si compreendendo o mundo", nos termos de Ricoeur (2008, p. 69). Tal compreensão não implica "trocar" o mundo por outra coisa, ainda que muitos insistam nessa troca. Fato é que, em suma, uma vez existindo no mundo, nosso olhar será sempre convencional, isto é, não conseguirá enxergar nada sem traduzir, interpretar e "completar" o vivido com nossos significados.

Ao reconhecer esse fato, alguns inferem que o mundo é incompleto, obscuro, distorcido. Perante o mesmo fato, a interpretação trágica diz o contrário: qualquer tipo 
de inadequação provém de nosso olhar, que é desabituado ao mundo. Pensar neste "olhar inadequado", que não cessa de tentar compreender o que vê, leva-nos diretamente a uma questão hermenêutica: a de como podemos compreender o “compreender" em si. Sigamos com esta questão em mente para o capítulo 3. 


\section{INTERLÚDIO III:}

\section{A reconquista do irremediável}

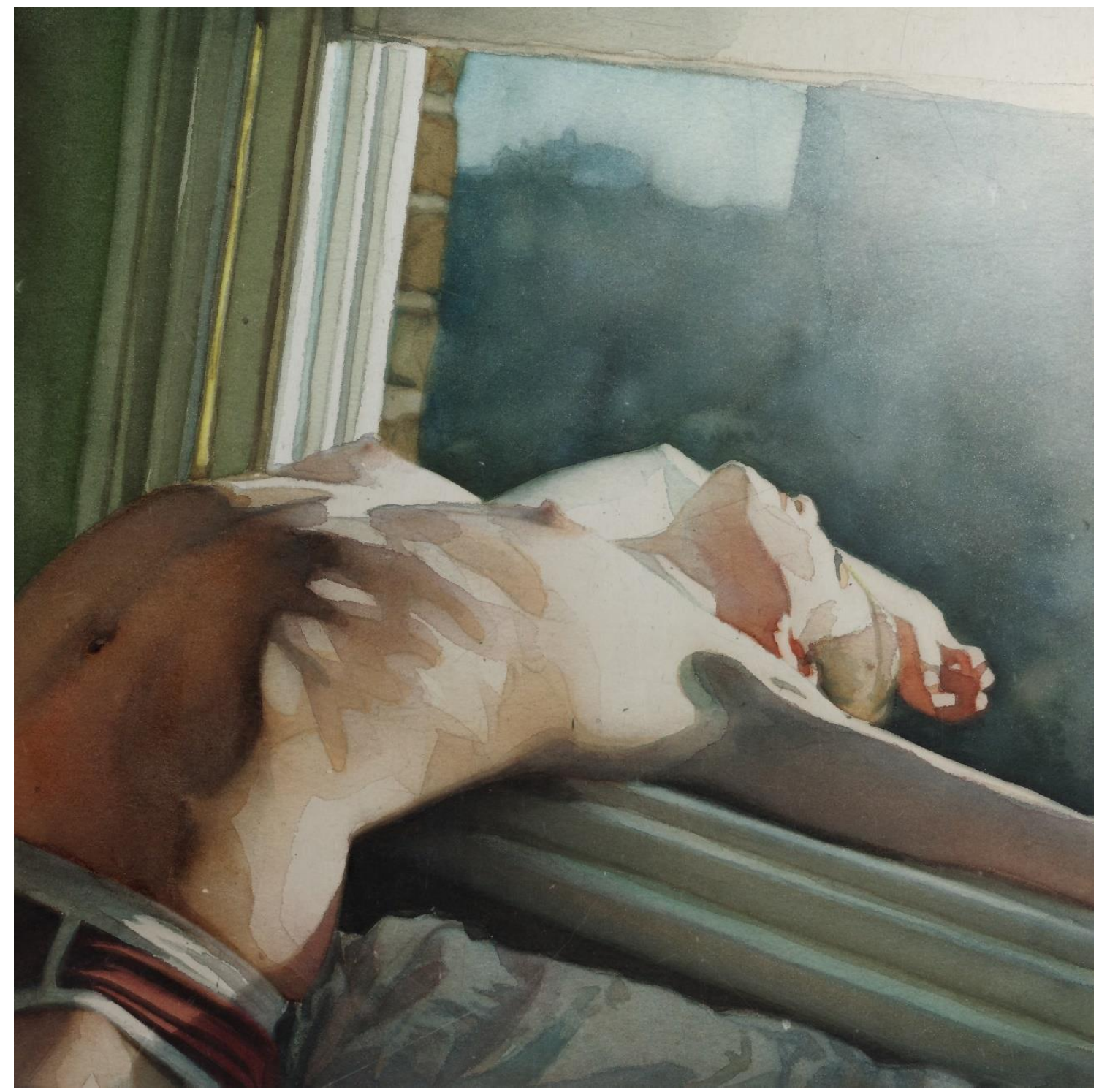

"Nosso fazer deve determinar o que deixamos - ao fazermos, deixamos" - assim me agrada, assim soa meu placitum [princípio].

— Nietzsche, A gaia ciência, IV, § 304

Ele ainda usa o mesmo par de brincos. Pensei, ao me deparar com um antigo colega de faculdade andando de mãos dadas com a filha. As crianças crescem. E o que se mantêm intactos são os gestos, iguais aos do pai. Difícil é rebobinar a fita do agora para organizar o tempo que passou e o que há para ser contado. Nada além de uma mesma e impertinente curiosidade, inabalável porquanto fugidia: que ficção é esta que 
se mantém em aberto acerca do "tempo que passa", como espécie de revelação daquilo que, para todos os efeitos, já se sabe?

Quer dizer, constata-se não apenas que as coisas mudam e nem notamos, mas também que perceber a mudança não muda o fato de que as coisas mudam: aquilo que por mera distração escapou à vista, que se prestássemos um pouco de atenção não continuaria ali sendo arrastado como parte indiferente do mundo. E quando temos a mais sincera intenção de explicar e procuramos a "expressão certa", nunca encontramos uma expressão à altura, recorrendo então a qualquer coisa que mude de forma considerável a própria intenção de explicar.

O que vejo acrescentado às palavras que estão por cima do que vejo? Mão pesada esta a do eu, que só se faz notar enquanto não estiver sendo procurada! As coisas não apenas parecem ser aquilo que não são, como também podem parecer apenas parecer o que não são, ocultando o fato de que são, de fato, o que parecem ser.

Pergunto aos alunos: algum de vocês ouviu falar em eterno retorno? Não tem nada a ver com chapeuzinho vermelho, já vou logo avisando.

É o que nos resta descobrir, meus caros, algo que sempre soubemos nesse tempo em que as crianças não pararam de crescer. A primeira briga, o primeiro beijo, aquela rua, aquele pátio e os numerosos registros aparecem como um retorno sem fim. Como estas palavras que saltam de meus dedos dizendo o que não faço ideia em algum outro lado do texto. Mais um lado, mais uma história, mais uma pessoa. Um novo lugar a cada novo instante, pois o que permanece não é a palavra escrita, o rosto congelado na foto, o pensamento dito ou não dito. O que permanece é um segundo para durar uma vida inteira e nenhum segundo a mais.

Se comparada a tudo o que já existiu e ainda há para existir, qualquer coisa que existe aqui e agora é infinitamente pequena e desprezível. Desde Parmênides essa situação era tida como impensável por não pertencer nem ao registro do que é - existir não consiste em ser o que nunca se deixou de ser — nem ao registro do que não é existir não é o mesmo que nada. Mesmo Deus, que nos promete uma vida eterna, nunca interferiu em tal condição: se minha alma é eterna entre outras tantas almas eternas, há apenas uma variação de escala, não de proporção.

Dizia Pascal: o mais e o menos são indiscerníveis no infinito. Se a vida que se esvai é a única coisa que temos, então ser é aquilo que se perde. A escolha mais inerte não é aquela que se abstém do ato, mas aquela que pretende superar a perda: daí que Nietzsche define o ressentimento não apenas como rancor acerca do real, mas também 
como impotência do rancor em se constituir em ato, como desistência do rancoroso em odiar propriamente, isto é, em dar a seu ódio uma expressão ou uma existência qualquer. É assim que a esperança permanece no jarro de Pandora sob a forma de remorso: não tanto por esperar o que nunca chega e sim por não conseguir fazer nada com o que se tem e, na falta de coisa melhor, continuar esperando. Vício que se alimenta da desistência da vida que se perde, sobretudo antes de perdê-la, reforçando pela via do ascetismo a espera e o desejo de permanência.

Aderir à perda, no entanto, não é o mesmo que desistir. Porque não há vontade, razão ou mistério por trás da perda. Não há nada a se perder numa existência passageira e desejada enquanto tal, pois no horizonte de cada perda intensifica-se o desejo pelo que já se tem. Quando se deixa de esperar, a espera cede lugar à entrega e o que se perde não mais se opõe ao que permanece. E o que permanece?

Nada além do exato instante em que a vida, suspensa pelos fios do tempo que passa, cai das alturas e mergulha no asfalto quente que a refletia no céu.

Próxima lição: o hipotálamo é a parte mais quente do sistema límbico. Os famosos "dois corpos que não ocupam um mesmo espaço" encarregar-se-ão de erguer as paredes para que o labirinto fique mais acolhedor a quem desejar manter-se lá dentro. Porque em torno de cada aqui gravita a esfera do ali. O centro está em toda parte, e o perímetro, em lugar nenhum. Se a contradição não cessa de acentuar-se, é menos por conta de uma imprecisão teórica do que pela precisão de se querer pensar o que não é pensável: o primeiro e último observatório no qual podemos contemplar tudo por um instante. A resultante imediata de falar sobre a vida não é senão uma espécie de instrumento óptico que nos faz discernir aquilo que, sem a própria limitação de tal instrumento, talvez não pudéssemos ver sozinhos.

Quem sabe o preço mais alto não seja o de repetir os gestos de uma civilização cujos deuses ninguém mais lembra? Esta é uma questão que deverá ser redefinida de acordo com o espaçamento e os caracteres enumerados. Antes será preciso passar no supermercado, este muro ecumênico das lamentações. Tarefa de casa: correr, tropeçar, amar e segurar o choro. Para não perder de vista o olhar de alguém, de uma divindade. 


\section{HERMENÊUTICA TRÁGICA}

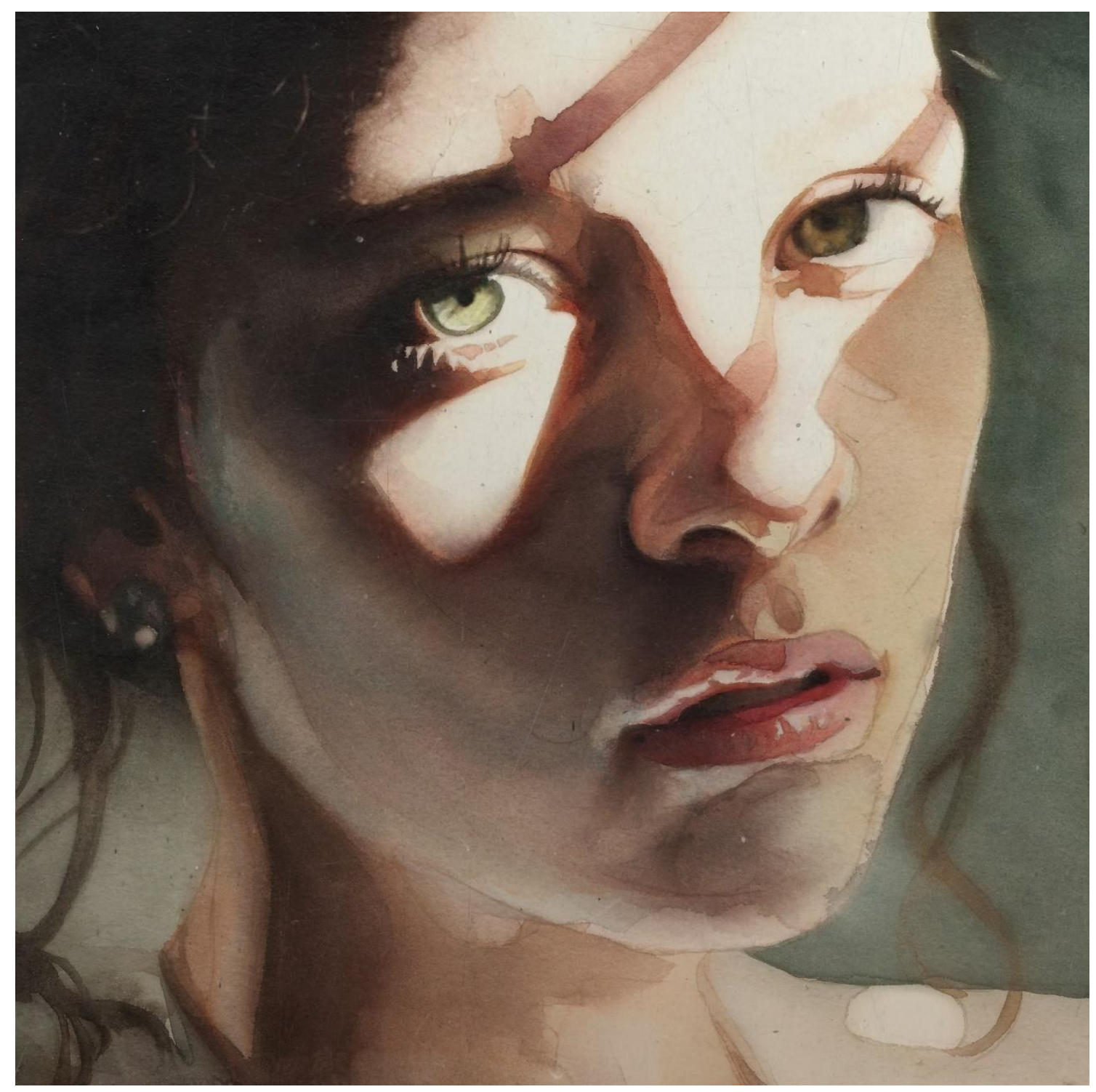

[Aqueles que me leem] não seriam meus leitores, mas leitores de si mesmos, não passando de uma espécie de vidro de aumento [...] o livro graças ao qual eu lhes forneceria meios de se lerem.

- Marcel Proust, O tempo redescoberto.

Questionei uma garotinha de seis anos sobre o que ela queria ser quando crescer. A resposta foi "atriz". Por quê? Explicou-me que uma atriz pode fingir ser qualquer pessoa. Mas então uma atriz deixa de ser ela mesma enquanto atua? Mais ou menos, esclareceu-me, porque a pessoa que a atriz finge ser é um pouco ela mesma e também um pouco as pessoas que assistem a seu espetáculo. Confessou-me que gosta de fingir 
ser outras pessoas. Retribui dizendo que talvez eu seja mais "eu mesmo" quando finjo ser outra pessoa. Então ela me perguntou, mudando de assunto, se eu tinha medo de morrer. Respondi com outra pergunta: você tinha medo disso quando você ainda nem havia nascido? Ela riu e disse que não dá para saber o que sentia antes de nascer. Pois é, prossegui, meu medo não é de morrer, mas de saber que eu morri.

Coloquemos da maneira mais simples possível: de um lado, constato a cada momento que o tempo passa e que tudo é provisório; de outro, imagino que estou num filme, à espera de mais um capítulo reconhecidamente emocionante e significativo, isto é, sempre em relação às convenções sociais. Por ser "de mentira", este meu filme é mais importante. Já sei qual será o final da história, mas para haver uma história é preciso vivê-la. Por sua vez, minha vida não se reduz à interpretação que faço dela, mas esta se alimenta daquela e a modifica. Não é ilusão, é o único procedimento que temos. Ilusório é denunciar todo e qualquer discurso, engajado ou desinteressado, em nome de uma visão mais legítima ou segura de como as coisas "realmente são" — como provavelmente já disseram ou ainda vão dizer àquela menina de seis anos.

Com isso quero pontuar que, se a vida se exprime por intermédio de narrativas, é à hermenêutica que uma "ontologia trágica" (se isso for possível) deve fazer apelo. Enquanto teoria da interpretação, ${ }^{36}$ a hermenêutica pressupõe não somente a noção de texto e a noção de apropriação efetuada pelo leitor, mas especialmente certo fluxo que vai de um para outro. Esse fluxo estabelece aspectos cruciais ao texto e à leitura: de um lado, somente há significado porque a linguagem é tratada como matéria que recebe uma forma; de outro, ao reconhecermos uma ação de (re)escrita inerente ao próprio ato da leitura ("exegese"), encontramos um movimento pendular entre o fundo ontológico do ato de compreender enquanto "modo de ser" humano e, no polo oposto, o fundo epistemológico prévio a qualquer modo de compreensão.

Para assimilarmos com acuidade tais questões, delineio a seguir uma breve genealogia da hermenêutica com ênfase na proposta de Paul Ricoeur, cujas implicações eu procuro em seguida aprofundar e relacionar com a perspectiva trágica. Ao fazer isso, transparecerá certa manobra "deleuziana" de minha parte: extraio apenas o que me interessa da hermenêutica ricoeuriana, apontando as voltas e reviravoltas de meu raciocínio para chegar a determinado ponto. Qual seja, a proposição de uma "hermenêutica trágica" que faça constelar uma rede conceitual — com ênfase nas

\footnotetext{
36 “[...] a hermenêutica é a teoria das operações da compreensão em sua relação com a interpretação dos textos" (Ricoeur, 2008, p. 23).
} 
noções de símbolo, ficção e criação estética — direcionada à ideia de "articulação simbólica", central neste trabalho. Por fim, encerro este capítulo com a análise de três obras de ficção narrativa, demonstrando com isso a via conceitual-metodológica pela qual sigo adiante, no quarto e último capítulo, na defesa do design como articulação simbólica.

\subsection{DA TEORIA DA INTERPRETAÇÃO À HERMENÊUTICA SIMBÓLICA}

Comecemos com a seguinte questão: o que é interpretar? Quem tem competência para fazê-lo? O ilustre Íon de Platão enchia-se de lágrimas ao recitar um poema de Homero, demonstrando com isso a necessidade de atingir os espectadores com o "sentimento" do discurso. Sócrates argumentava que isso só poderia ocorrer caso o intérprete estivesse "inspirado", isto é, possuído por um deus e transportado para fora de si, como uma cegueira apaixonada. Assim, se o intérprete tem a função de interpretar interpretações (as do poeta), ele se torna o elo de uma cadeia que se inicia com o próprio poeta e termina no espectador. Mas não há, explica-nos o Sócrates de Platão, ciência ou arte nessa cadeia, pois, se assim fosse, tanto o poeta como o rapsodo saberiam explicar o que sentiram/escreveram/recitaram em vez de ficarem "fora de si", possuídos por um deus e, portanto, sem saberem falar daquilo que interpretam.

Deste modo, há no Íon o desenrolar de uma argumentação que ainda hoje é emblemática: se um texto é sempre derivado de outros textos/temas, então caberá a especialistas interpretar com rigor as palavras em causa. $\mathrm{O}$ médico, o carpinteiro, o pescador, o escultor e tantos outros só saberão falar das partes que tratam de seus ofícios nos livros de Homero. Mas para haver essa rede de interpretações parciais, é preciso haver um não saber essencial, uma não interpretação: se interpretar é dizer, explicar ou traduzir, não se pode saber ao certo qual a pré-compreensão que anima e possibilita cada um destes gestos. Evidentemente, o absurdo de uma asserção como essa somente se revela sob o pressuposto de que o interpretar, na medida em que é um ato apaixonado, possui razões que a própria razão desconhece — premissa esta que reverte contra o próprio Sócrates sua denúncia sobre um conhecimento genérico, por ele conclamado como "ordem geral” que só aos deuses está reservado conhecer.

No entanto, podemos dizer que no nível mais elementar e mais banal dessa argumentação socrática — toda interpretação é parcial, nunca absoluta — reside apenas 
a polissemia, este fato de as palavras e ideias terem mais de uma significação quando consideradas fora de seu uso em determinado contexto. Tal polissemia envolve não uma ordem divina, mas o papel seletivo dos contextos em relação à determinação do valor atual que adquirem as palavras e ideias numa expressão específica, veiculada por um locutor específico a um ouvinte que se encontra numa situação específica. É basicamente isto que, incomodando Sócrates, defendiam os sofistas: uma sensibilidade ao contexto, portanto ao acaso e às circunstâncias, como complemento e contrapartida necessários à polissemia inelutável. Com tal sensibilidade, não se preenchem mais as condições da interpretação mediante codificações parciais (em função de uma ordem geral), e sim por meio do diálogo e da ressignificação circunstancial.

Em todo caso, o esforço para se extrair um problema geral da atividade de interpretação, interrogando as condições de possibilidade de toda compreensão, parece ser o eixo genealógico da significação da hermenêutica. O termo grego hermeneuein significa declarar, anunciar, interpretar ou traduzir, não sendo improvável que tal palavra derive de Hermes, ${ }^{37}$ o mensageiro dos deuses, o que nos remete à mediação de dois mundos distintos. Não obstante, o uso mais disseminado da palavra no âmbito teológico permanece aristotélico, isto é, pressupondo a permanência de uma essência como fundamento do sentido mediado pela linguagem.

Embora o termo em questão só se generalize a partir dos séculos XVII e XVIII, ${ }^{38}$ obtendo repercussão filosófica a partir da fundamentação formulada por Friedrich Schleiermacher, foi muito antes, com a expansão do cristianismo, que a problemática hermenêutica começou a adquirir pertinência filológica, isto é, em relação ao recenseamento das Sagradas Escrituras, à sua crítica, autoria ou cronologia. Com o propósito de conciliar o Antigo e o Novo testamentos, a hermenêutica cristã radicada por Agostinho segmentou-se numa miríade de escolas - algumas se restringindo ao sentido histórico-literal da narração bíblica, outras procurando atingir a atualidade da revelação da palavra divina, e assim por diante. Esta tensão entre as várias leituras possíveis do texto sagrado continuou sem um desfecho ao longo dos séculos, ${ }^{39}$

\footnotetext{
${ }^{37}$ De acordo com Richard E. Palmer (1997, p. 24), em Hermenêutica, "a palavra grega hermeios referiase ao sacerdote do oráculo de Delfos. Esta palavra, o verbo hermeneuein e o substantivo hermeneia, mais comuns, remetem para o deus-mensageiro alado Hermes, de cujo nome as palavras aparentemente derivaram (ou vice-versa?)".

38 Segundo Jean Grondin (1993, p. XIII), em L'Universalité de l'herméneutique, o termo latim hermeneutica somente aparece atualizado nos registros do século XVII. A despeito da história dos usos deste termo, cf. Weinsheimer, 1991.

${ }^{39}$ Vale mencionar aqui a leitura atual proposta pelo teólogo italiano Pier Cesare Bori (1991), em seu L'interprétation infinie. Para defender a tese de que "a Escritura progride com aqueles que a leem", Bori
} 
exemplificada secularmente pelas tradições católica e protestante.

O que nos importa reter neste registro teológico é que, para garantir uma unidade fundamental do texto bíblico, é preciso pressupor, sobretudo na escola patrística, um controle exercido sobre a polissemia. ${ }^{40}$ Era necessário manter uma superioridade da acepção espiritual sobre a literal, ao contrário do que vemos, por exemplo, no Tratado Teológico-Político de Spinoza, escrito em 1670, que preza pelo "sentido" em vez da "verdade" do texto bíblico. Spinoza (2008) queria interpretar o texto por ele mesmo, obtendo a fé cristã como resultado da interpretação e não em seu início ou pressuposto. Embora a intenção do filósofo holandês fosse claramente a de conciliar fé e razão, sem confundi-las entre si, sua defesa pela autonomia do texto demarcou avant la lettre o foco objetivo sinalizado por Schleiermacher e posteriormente reformulado por Ricoeur.

Com efeito, será somente no século XIX que a hermenêutica deixará de ser apenas uma prática associada à leitura bíblica ou à jurisprudência para assumir-se como disciplina filosófica, nomeadamente com Schleiermacher e Wilhelm Dilthey. É interessante notar como uma problemática historicamente teológica adquiriu relevância filosófica justamente num momento que coincide com a crítica à metafísica. Se com o cogito cartesiano e a revolução copernicana de Kant já não se podia encontrar garantias para o conhecimento fora do sujeito, restava ainda a herança neokantiana que recebia da filosofia romântica sua mais fundamental convicção: a de que o espírito se manifesta pelo ato criador original de cada individualidade. É compreensível que o romantismo tenha proporcionado um clima favorável ao projeto incipiente de uma hermenêutica filosófica: na esteira da crítica kantiana, era preciso medir as condições do conhecer antes de se enfrentar a natureza do ser. No entanto, será somente pela leitura nietzschiana de Heidegger, em meados do século XX, que tal projeto assimilará que não pode haver a questão do "ser", só pode haver a questão do "sentido de ser".

Vejamos antes como Schleiermacher desenvolveu sua hermenêutica romântica. ${ }^{41}$

resgata as fontes da hermenêutica antiga, tomando como modelo Gregório, o Grande (séculos VI-VII), que, ao fazer uma análise do livro do profeta Ezequiel, propôs uma interpretação "moral" das palavras misteriosas. O teólogo então argumenta que a adequação às convenções de cada época é o que potencializa a interpretação infinita das Sagradas Escrituras.

${ }^{40}$ Conforme dita Tomás de Aquino, em sua Suma Teológica (questão 1, art. 10): “Tudo o que seja necessário à Fé e esteja contido no sentido espiritual, está necessária e claramente contido noutras passagens num sentido literal."

${ }^{41}$ Sabe-se que Schleiermacher nunca chegou a publicar ou mesmo sistematizar suas reflexões sobre hermenêutica. Porém, Heinz Kimmerle publicou em 1928 o Schleiermacher Werke I, um livro póstumo que reúne os textos de Schleiermacher sobre hermenêutica, abrangendo o período que vai de 1805 a 1833. Ademais, sabe-se também que foi por ocasião de seu projeto de traduzir, com F. Schlegel, as obras 
O filósofo alemão, descontente com o estado caótico e incerto do conhecimento de seu tempo, decidiu levar a cabo uma elucidação do que há de geral nas operações utilizadas no ato de compreender. De maneira similar à moral pré-rafaelita em prol de um olhar puro e inocente, Schleiermacher defendia o uso que a criança faz da compreensão como "reconstrução" para capturar o sentido mais elevado das palavras. A este romântico sentido "mais elevado" era necessário contrapor, de maneira kantiana, o fracasso de todo modelo de consciência, o que equivale a dizer que, se o pensamento se exprime por palavras, deve haver um abismo intransponível entre o que se diz e o que se quer dizer. Tal abismo é o que sustenta a hesitação de Schleiermacher em privilegiar o texto que comanda a leitura ou o autor em suas intenções.

Sua solução então consiste em estabelecer dois critérios interpretativos distintos: o gramatical e o psicológico. O primeiro sublinha a importância da linguagem e do contexto linguístico no qual inserimos qualquer palavra. Por sua vez, a interpretação psicológica dirige-se à singularidade, até mesmo à genialidade, da mensagem do autor, levando-se em conta sua vida e personalidade. A ideia é que todo texto não apenas pressupõe uma língua já dada e atuante, como também algo que singulariza um pensamento e, por isso mesmo, o autor que o exprime. Com a interpretação gramatical, somos remetidos para a língua e para algo "objetivo": compreender um discurso é partir da língua e servir-se dela para esse mesmo efeito. Com a interpretação psicológica, "subjetiva" e propriamente discursiva, a compreensão tem por objeto aquele que fala, a ideia do autor, ficando a língua esquecida. Conforme revisa Ricoeur (2008, p. 27-28):

\footnotetext{
[Enquanto] o kantismo só conseguiu evidenciar um espírito impessoal, portador das condições de possibilidade dos juízos universais, [...] o programa hermenêutico de Schleiermacher era portador de uma dupla marca - romântica e crítica. Romântica por seu apelo a relação viva com o processo de criação e crítica por seu desejo de elaborar regras universalmente válidas da compreensão. [...] Ora, se as duas interpretações possuem direitos iguais, não podem ser praticadas ao mesmo tempo. Schleiermacher precisa: considerar a língua comum é esquecer o escritor, compreender um autor singular é esquecer sua língua que é apenas atravessada. Ou percebemos aquilo que é comum, ou então percebemos o que é próprio.
}

Em outros termos, Schleiermacher é romântico ao querer compreender um autor

completas de Platão, que Schleiermacher sentiu necessidade de apurar instrumentos para uma "hermenêutica geral", cuja repercussão acadêmica lhe foi significativa ainda em vida. 
melhor do que ele mesmo se compreende; e é crítico, no sentido transcendentalkantiano, por sustentar uma unidade original que indicaria na língua os limites da compreensão. Em seus últimos escritos, encontramos procedimentos metodológicos para cada modalidade interpretativa: o método divinatório, para a gramatical, e o método comparativo, para a psicológica. Enquanto o primeiro é intuitivo e espontâneo, pretendendo compreender diretamente o que dizem as palavras, o método comparativo preocupa-se em apreender uma individualidade por contraste, isto é, na diferença produzida em relação a outros discursos. É apostando num caráter universal da compreensão que Schleiermacher afirmará que os dois métodos necessitam um do outro, o que o levará a propor aquele que talvez seja o conceito mais fundamental de sua hermenêutica: a ideia de um "círculo hermenêutico", que assenta na convicção de que só é possível compreender um texto a partir da totalidade da obra e, inversamente, que só se compreende a totalidade de uma obra a partir do estudo das suas partes.

Essa noção será apropriada tanto por Heidegger quanto por Ricoeur, ambos deslocando a ênfase na busca romântica dos conteúdos subterrâneos para o sentido e a referência do próprio texto. Significa que, no contato interpretativo com a expressão de um autor, transformo-me num outro ao mesmo tempo em que o transformo num eu, elevando a obra interpretada ao nível de intermédio principal. Tal distanciamento do espírito romântico, no entanto, só ocorrerá após a insistência de Wilhelm Dilthey em querer ampliar a investigação neokantiana do "espírito humano", tomando agora em consideração a perspectiva hegeliana da história.

De um lado, entre Schleiermacher e Dilthey, há os historiadores idealistas alemães do século XIX, como Leopold von Ranke e Johann G. Droysen. De outro, o tempo de Dilthey é o da completa recusa do hegelianismo e o da apologia do conhecimento experimental (positivismo filosófico). É sobre esse cenário de fundo que Dilthey coloca sua questão principal: como o conhecimento histórico é possível? De um modo mais amplo: como as ciências do espírito, em contraposição às naturais, são possíveis? Sua estratégia foi dotar as ciências do espírito de uma metodologia e de uma epistemologia tão "respeitáveis" quando as das ciências da natureza. Para tanto, seria preciso reter o foco psicológico da hermenêutica de Schleiermacher e, ao mesmo tempo, recorrer à "fenomenologia do espírito" de Hegel para prosseguir a partir de onde Kant havia parado. ${ }^{42}$ Deste modo, elegendo a psicologia como ciência basilar para a

\footnotetext{
${ }^{42}$ Aqui alguém poderia objetar: mas não foi Hegel a testemunha de uma esfera do espírito - o espírito objetivo, o espírito das instituições e das culturas — que de forma alguma se reduz a um fenômeno
} 
compreensão do indivíduo agindo na sociedade e na história, Dilthey defendia que, antes da coerência de um texto, vem a da história, considerada como espírito coletivo necessário para compreendermos cada espírito individual.

Surge assim uma hermenêutica psicológica, sendo a autonomia do texto apenas um fenômeno provisório e aparente, pois somente a vida espiritual poderia fixar-se em conjuntos estruturados suscetíveis de serem compreendidos. Mais precisamente, a hermenêutica aparece aqui ela própria fundada sobre a psicologia, constituindo apenas uma camada superficial de uma cadeia interpretativa maior, que vai da história ao indivíduo. ${ }^{43}$ A história universal adquire então um teor espiritual, de modo que a hermenêutica se torna o acesso do indivíduo a esse grande saber absoluto. Ainda assim, permanecia não solucionado o dilema romântico entre uma filosofia subjetiva e a filosofia hegeliana do espírito objetivo. Porém, como observa Ricoeur (2008, p. 36),

Dilthey percebeu perfeitamente o âmago do problema: a vida só apreende a vida pela mediação das unidades de sentido que se elevam acima do fluxo histórico. Percebeu um modo de ultrapassagem da finitude sem sobrevoo, sem saber absoluto, que é, propriamente, a interpretação. Com isso, aponta a direção na qual o historicismo poderia ser vencido por ele mesmo, sem invocar nenhuma coincidência triunfante com qualquer saber absoluto. Contudo, para levar adiante essa descoberta, será preciso que se renuncie a vincular o destino da hermenêutica à noção puramente psicológica de transferência numa vida psíquica estranha, e que se desvende o texto, não mais em direção a seu autor, mas em direção ao seu sentido imanente e a este tipo de mundo que ele abre e descobre.

Com efeito, o que Dilthey deixou em aberto no limite de sua fé neokantiana foi a possibilidade de cavar por debaixo de seu empreendimento epistemológico, a fim de elucidar condições ontológicas alheias a um pretenso saber absoluto. Tomemos o seguinte panorama: do "não resolvido" de Schleiermacher surgiram as reflexões de Dilthey, e das "aporias" deste somos conduzidos a Heidegger e a Gadamer. Enquanto os

psicológico? Sem dúvida, mas é preciso lembrar que Dilthey ainda pertence a esta geração de neokantianos para a qual o pivô de todas as ciências humanas é o indivíduo, considerado, é verdade, em suas relações sociais, mas fundamentalmente singular e psicológico.

${ }^{43}$ A fim de explicitar o absurdo deste tipo de asserção hegeliana, vale aqui mencionar rapidamente que, em Tempo e narrativa, ao pôr em causa a falsa dissimetria entre a "realidade" do passado histórico e a "irrealidade" do presente cotidiano, Ricoeur sublinha a prevalência da noção de "representância" (représentance) enquanto reconstrução constante do passado histórico a partir da função reveladora e transformadora da ficção. Cf. Mundo do texto e mundo do leitor. In: Ricoeur, 1996, p. 228-263. 
dois primeiros se encarregaram da passagem de uma hermenêutica regional (teológicofilológica) a uma geral (filosófica), os outros dois ocuparam-se da passagem dos pressupostos epistemológicos da hermenêutica para uma ontologia. “[...] Surge uma questão nova: ao invés de nos perguntarmos como sabemos, perguntaremos qual o modo de ser desse ser que só existe compreendendo" (Ricoeur, 2008, p. 37).

Em Heidegger, a teoria do conhecimento é, desde o início, condicionada por uma interrogação que a precede e que versa sobre o modo como um ser encontra a si mesmo, isto é, em sua situação no mundo. A prioridade dessa situação é a ênfase dada no conceito de Dasein, o ser-aí que somos nós, desde sempre lançados no mundo antes mesmo de o encararmos como um objeto que se opõe a um sujeito. Se o humano sempre "está no mundo", se não existe sujeito fora do mundo, Dasein designa o lugar onde se manifesta este ser-no-mundo, de modo que a hermenêutica opera na relação do ser com a situação na qual se este encontra, em sua posição de ser-aí.

O que importa neste ponto é que a questão do "mundo" tomou o lugar prioritário que antes ocupava a questão do indivíduo em Dilthey - ao mundanizar o compreender, Heidegger o despsicologizou. O sentimento de "mundanidade" precede qualquer ordenação objetiva ou subjetiva do mundo; é necessário, antes, encontrar-se na condição de habitante desse mundo, a partir da qual há situação, compreensão, interpretação. $\mathrm{O}$ compreender não se dirige mais à apreensão de um fato, mas de uma possibilidade de ser. Por conseguinte, compreender um texto não é descobrir um sentido inerte que nele estaria contido, mas revelar a possibilidade de ser indicada pelo texto. Este movimento de situar-se a partir de um ser-lançado prévio, sublinha Ricoeur (2008, p. 41), não deve ser confundido com uma empreitada existencialista:

\footnotetext{
Uma pequena expressão separa Heidegger de Sartre: sempre já: "Este projeto não possui nenhuma relação com um plano de conduta que o ser-aí teria inventado e segundo o qual edificaria seu ser: enquanto ele é ser-aí já se projetou sempre e permanece em projeto enquanto for". O que importa, aqui, não é o momento existencial da responsabilidade ou da livre-escolha, mas a estrutura de ser a partir da qual há um problema de escolha.
}

O que fica explicitado na noção de um ser-lançado prévio é o "enquanto" ao qual o ser apenas fornece uma expressão provisória. Daí que o conceito de "círculo hermenêutico" não mais opera em termos de todo e partes, mas em termos de implicação mútua: o ser compreende a si ao compreender o mundo. Tal conceituação do 
ser-aí, no entanto, mostra-se ainda incapaz, para Ricoeur (2008, p. 44), de proceder ao movimento de retorno à questão propriamente epistemológica, de modo que "uma filosofia que rompe o diálogo com as ciências só se dirige a si mesma". De fato, o destaque das antecipações segundo as "coisas mesmas" explicita a obsessão heideggeriana em enraizar mais profundamente o círculo hermenêutico, impedindo que se retome a questão epistemológica. Ele não foi capaz, enfim, de dar conta da inevitabilidade das interpretações já dadas no ato mesmo de compreender: partimos sempre de uma compreensão prévia, de algo vivido antes de ser pensado — "alienação" esta que, para Heidegger, nos impediria de compor um sentido autêntico da existência.

Tal aporia não anula, por certo, a contribuição de Heidegger à hermenêutica contemporânea, sobretudo no que condiz ao redirecionamento da hermenêutica não mais às leis da análise textual ou psicológica, mas ao registro do existente (embora tal registro tenha se encerrado como princípio e fim da compreensão). De sua tentativa de compreender a compreensão resultou a noção da compreensão enquanto "modo de ser" (Dasein): não apenas "somos para compreender" como, antes disso, "compreendemos para ser". E de sua conceituação do círculo hermenêutico, devemos reter o fato de que estamos sempre já implicados naquilo que queremos compreender.

Em relação à unilateralidade ontológica criticada por Ricoeur, trata-se de um impasse que nos conduz ao problema central da filosofia de Hans-Georg Gadamer, que em Verdade e método estabelece uma oposição antinômica em relação ao procedimento hermenêutico: ou se privilegia a atitude metodológica, cujo distanciamento alienante possibilita o estatuto científico das ciências humanas, embora se perca a densidade ontológica do que é estudado, ou se destaca a verdade das experiências primordiais de compreensão e mundanidade, renunciando então à objetividade do método científico. Em suma, o próprio título do livro confronta o conceito heideggeriano de "verdade" com o conceito diltheyniano de "método". O longo percurso histórico traçado por Gadamer antes de expor suas próprias digressões atesta sua estima pela noção de "consciência histórica" que era central a Dilthey, o que o leva a sustentar que a hermenêutica só obteve consistência filosófica a partir da luta do romantismo contra o positivismo e, em seguida, do debate heideggeriano contra o neokantismo.

Sem dúvida, a intenção de Gadamer era recuperar o rigor metodológico reivindicado por Dilthey, porém sem recair na viseira do romantismo que, segundo o autor, travava seu combate sobre um terreno definido pelo adversário — a saber, o papel da tradição e da autoridade na interpretação. Sua estratégia consistiu em afirmar que o 
homem está situado desde sempre no seio das tradições e em propor uma nova teoria da consciência histórica: a história me precede e se antecipa à minha reflexão; logo, pertenço à história antes de pertencer a mim mesmo. Não é difícil notar, com Ricoeur, que Gadamer não conseguiu escapar ao esquema romântico do distanciamento crítico: o ato de assumir uma instância "maior" a mim mesmo pressupõe outra alienação, a de uma consciência que reivindica soberania epistemológica.

Com efeito, é finalmente esse impasse epistemológico que é superado por Ricoeur, para quem as objetivações estruturais do texto fazem dele um medium, ou seja, é sempre por meio dele que podemos compreender o mundo e a nós mesmos. Assim, um movimento de retorno, notadamente pendular, em direção tanto ao registro epistemológico quanto ao ontológico, é formulado: “o que deve ser interpretado, num texto, é uma proposição de mundo, de um mundo tal como posso habitá-lo para nele projetar um de meus possíveis mais próprios. É o que chamo de o mundo do texto, o mundo próprio a este texto único" (Ricoeur, 2008, p. 66). É nesta noção de "mundo do texto" que reside o centro de gravidade da proposta hermenêutica de Ricoeur (ibidem, p. 53): “Toda a discussão anterior servirá apenas para preparar o deslocamento do problema do texto em direção ao do mundo que ele abre. Ao mesmo tempo, a questão da compreensão de si, que, na hermenêutica romântica, ocupa um lugar de destaque, vêse transferida para o fim, como fator terminal."

Para aprofundarmos tal proposta, cumpre recapitularmos, aos poucos, alguns dos preceitos trágicos delineados no capítulo 2. No âmbito do real, vimos que o primeiro aspecto das coisas é o de aparecer, e não o de propriamente ser. O que "existe" está sempre em transição, tirando do acaso uma mesma possibilidade: não há diferença ontológica entre um monte de areia, um ser vivo e um computador, todas as coisas podem existir e deixar de existir somente "ao acaso".

Ora, a infinidade de diferenças entre as coisas existentes não implica a necessidade de haver diferentes níveis ontológicos. O trágico nega a possibilidade de diferenças de nível, de natureza, de relevo, reduzindo então todas as existências a um mesmo nível, reagrupando-as num mesmo conjunto casual na superfície do qual todas as combinações são espontaneamente possíveis — homem, árvore, pedra —, e a partir do qual somente pode existir a infinidade das diferenças. Em suma, todas as coisas se equivalem sob um prisma ontológico segundo o qual nada há além de "aparências ao acaso"; ao mesmo tempo, é esta unidade ontológica que garante a infinidade das 
diferenças ${ }^{44}$ — unidade que não significa síntese, mas impossibilidade de distinguir ordens diferentes no caráter constitutivamente casual do que existe.

Claro está, portanto, que o dado e o sentido são irredutíveis. O ser não é um dado, tampouco se deixa reduzir a um sentido (como "subjetividade"). Está vinculado ao mundo por meio do acaso, assim como outras organizações que existem, subsistem por um tempo e depois se destroem. Por isso não há propriamente "ser", as coisas apenas podem aparecer e desaparecer num dado momento. Sendo assim, a própria noção de existência aparece ao homem mediante elementos simbólicos, de tal forma que toda visão do ser, toda concepção ontológica, já é uma hermenêutica.

Que diferença isso faz? A hermenêutica passa a ser vista aqui como algo que perpassa a ontologia, a epistemologia e até a antropologia, mas sem esgotar-se nelas. Tomemos inicialmente a antropologia: por um lado, ela se define como um discurso sobre o homem, mas de tal modo que não estão separados aquele que fala e aquilo sobre o que se fala. Logo, qualquer pergunta sobre o "ser" não se descola da condição de ser, o que equivale dizer que toda ontologia é antes uma antropologia. Por outro lado, contudo, tanto a antropologia quanto a ontologia são antes uma hermenêutica: não há a questão do "ser", só há a questão do "sentido de ser".

Nada além do sentido há para ser compreendido, ainda que, ao mesmo tempo, sob um viés nietzschiano, qualquer sentido tenda a substituir o que é. Dessa maneira, retornamos a um enunciado epistemológico: não é possível estabelecer qualquer ontologia, nem mesmo enunciar a proposição que se queira, sem antes, numa anterioridade condicionante, subjacente ao que se diz, lançar mão de uma imagem ou ideia de ser, homem ou mundo. Sem a articulação dessas imagens e ideias, qualquer discurso filosófico é mudo. Com efeito, uma das definições do trágico consiste, conforme conceitua Rosset (1989, p. 121), nisto “que não se pensa (não há 'leis do trágico'), mas também [n]isso a partir do que todos os pensamentos são - a um certo nível - revogados. Ele designa assim, num certo sentido, a impossibilidade da filosofia. Acrescentar-se-á: talvez, também, uma de suas mais insistentes razões de ser”.

Penso que Ricoeur complementaria essa ideia dizendo que é pela hermenêutica que a filosofia permanece possível, por meio dessa atitude criativa do compreender. Mas o que dizer da consciência que compreende? Que ela não é imediata, porém sempre mediada; não é uma fonte, mas uma tarefa, a tarefa mesma de compreender. Ou seja,

\footnotetext{
${ }^{44}$ É o que leva um filósofo como Deleuze, por exemplo, a afirmar, contra o racionalismo clássico, a única e universal existência da diferença, sem uma referência prévia a uma ideia do idêntico. Cf. Deleuze, 1988.
} 
nem mesmo é de "consciência" que se trata, ao menos no sentido de coisa inalienável: não há um lugar não alienado de onde possa falar o filósofo, o cientista ou mesmo o hermeneuta, porque mesmo a ideia de um lugar universalmente neutro não passa de outra mediação. ${ }^{45}$ Então em que medida o compreender é um ato criativo? $\mathrm{Na}$ implicação da (re)escrita na leitura (exegese), na efetuação da linguagem como discurso, na efetuação do discurso como obra estruturada, na proposição de um mundo a partir da obra e no próprio espelhamento (mediação e articulação) de narrativas a partir dos textos.

Delineio tais questões a seguir, ponto a ponto. Importa entendermos que, em suma, é o compreender que ativa o potencial do imaginário frente às diferenças produzidas ao acaso. Vimos que o imaginário se manifesta por cadeias de sentido, como numa cebola de infinitas "cascas" - cujo dinamismo Ricoeur explorará exaustivamente em Tempo e narrativa. Ao demonstrar como a solução temporal (como memória e história) é sempre imaginária, Ricoeur sublinhou o papel primordial que a imaginação desempenha não apenas nas explicações do mundo (inclusive nas mais lógicas e apofânticas), mas antes no compreender que nos situa nele.

Por isso que, no pensamento de Ricoeur, o trânsito da hermenêutica para a ontologia surge não como enraizamento do ser-lançado, como queria Heidegger, mas quando, ao interpretarmos uma obra, ${ }^{46}$ deixamos de procurar nela algum sentido inerte ou voz intrínseca para finalmente dialogarmos com o mundo que ela veicula, numa integração que se dá no tecido imaginário. Daí a noção de que o texto possui "vida autônoma", isto é, precisamente pela proposição de mundo que por ele se abre: ao interpretar um texto, compreendo-me a mim mesmo, porque o texto me amplia, dialoga comigo, interfere na minha proposição de mundo ao propor-se como mundo.

Vejamos mais detidamente de que maneira esta ideia de "mundo do texto" constitui o centro de gravidade da questão hermenêutica em Ricoeur. Em primeiro lugar, podemos perguntar: o que acontece com uma expressão qualquer quando ela passa da fala ao texto? À primeira vista, a escrita parece introduzir apenas um fator material: o registro físico, à mercê da destruição. Mas acontece que, na esfera discursiva, a escrita torna o texto autônomo em relação ao autor e ao leitor. O discurso

\footnotetext{
${ }^{45}$ É por meio deste simples argumento que Ricoeur logra em superar o engodo do "esclarecimento" que, na hermenêutica contemporânea, ainda se verifica na obra de Gadamer, ao atribuir autoridade ao saber das tradições; e, nos estudos de Habermas, ao elaborar sua "crítica das ideologias". A este respeito, cf. Ciência e ideologia, segunda parte de Hermenêutica e Ideologias (Ricoeur, 2008, p. 71-183).

${ }^{46}$ A despeito das noções de "texto" e "obra", devemos apenas levar em conta que todo texto é também uma obra, e vice-versa, na medida em que a linguagem é tratada como matéria que recebe uma forma.
} 
do texto não coincide mais com aquilo que o autor quis dizer, passando mesmo a interferir, a reorganizar e a reatualizar a expressão que o precede. A célebre Autopsicografia de Fernando Pessoa (1980, p. 104) descreve precisamente esse movimento:

\footnotetext{
O poeta é um fingidor.

Finge tão completamente

Que chega a fingir que é dor

A dor que deveras sente.

E os que leem o que escreve,

Na dor lida sentem bem,

Não as duas que ele teve,

Mas só a que eles não têm.
}

O poeta não mente sua dor, mas a "finge" de tal forma que a dor fingida torna-se a que ele mesmo sente. Primeiro, a dor expressa no texto é fingida, ou seja, não se refere à dor individual do autor. Depois, o que o leitor sente não é a dor do poeta (psicológica), tampouco a que foi transfigurada no texto (objetiva), mas outra dor, aquela compreendida diante do texto, que também não é a que o leitor tem. De um lado, o poeta nutre-se de sua própria dor para imaginar outra dor, aquela que assume a forma poético-discursiva. De outro, o leitor, ao ler a dor imaginada no poema, não vivencia a dor primeira do poeta nem sua dor imaginada, mas uma terceira dor, a que ele, leitor, imagina. Logo, a dor fingida do poeta reflete, pelo texto, alguma dor que o leitor de fato viveu e que serve de matriz para sua dor imaginada. A autonomia do texto irrompe, assim, da relação do leitor com o texto. Conforme sintetiza Rogério de Almeida (2015a, p. 138),

O processo é circular: forjamos racionalmente nossa dor, isto é, transcriamola em obra. Mas a obra é lida e transcriada em sentimento. E é essa nova dor que realimentará o circuito no qual razão e sentimento se retroalimentam na mediação do homem consigo e com os outros.

Daí a capacidade do texto de, tanto do ponto de vista objetivo quanto do psicológico, "descontextualizar-se de maneira a deixar-se recontextualizar numa nova situação: é o que justamente faz o ato de ler [e de escrever]" (Ricoeur, 2008, p. 62). 
Desse modo, "As obras atestam que a relação do homem com o mundo é criativa" (Almeida, op. cit., p. 139), o que se dá como experiência ficcional, conforme Marcos S. Pagotto-Euzebio (2014, p. 71) a descreve: "Somos revelados a nós mesmos pela narrativa que nos conta. Entendo a mim mesmo quando elaboro uma narrativa que me descreve, em um entender que é, também, um criar."

A recusa a compreender um texto pela intenção de seu autor é o que afasta por definitivo a proposta ricoeuriana da concepção romântica da hermenêutica, acentuando em contrapartida o processo de ler e escrever. ${ }^{47}$ Convém aqui abrirmos um rápido parêntesis dedicado à noção de autor. O problema da autoria no panorama da hermenêutica, como vimos, era oscilante: ora se interpretava a obra a partir da intenção do autor, ora se prescindia dessa intenção em prol do texto. Ampliando o panorama, sabe-se que correntes literárias de meados do século $\mathrm{XX}$, como o formalismo russo e a nova crítica, penderam a prescindir da intenção do autor - o que levará, na década de 1960, autores como Foucault e Barthes a apostarem no desaparecimento ou morte do autor, coincidindo com o desaparecimento ou morte do "eu" (noção moderna de subjetividade). Por conseguinte, a função do "leitor" tem aparecido, para algumas perspectivas hermenêuticas, como critério central de significação do texto.

A visada de Ricoeur diferencia-se de todas essas tendências: ao renunciar a apreensão da alma de um autor, não ficamos limitados à estrutura textual nem ao espírito do leitor (que assim assumiria o pedestal romântico do autor). É somente o discurso, o "mundo do texto", que abarca leitores e autores, solicita diálogo e exprime o mundo. A questão nova que se coloca é que, como dizíamos, quando o discurso se torna texto pela escrita, deixa de haver uma referência seguramente ancorada. Só que, não havendo mais "situação comum" entre escritor e leitor (como há entre quem fala e quem escuta), não significa que o discurso textual torne-se "desvinculado" do real. Por certo ele deixa de descrever ordinariamente o real, mas faz operar, em contrapartida, uma incidência de outro nível: pelo ser-no-mundo, na relação de cada leitor com o real.

É esta dimensão referencial "em aberto" do texto, mais do que o texto em si (enquanto mídia material), e especialmente nas formas de ficção e poesia, ${ }^{48}$ que traz o

\footnotetext{
${ }^{47}$ Ricoeur (2008, p. 63) argumenta que, mediante o texto, a relação entre escrever e ler nunca é análoga à relação entre falar e ouvir: "A passagem da fala à escrita afeta o discurso de vários modos; de uma maneira especial, o funcionamento da referência fica alterado quando não nos é mais possível mostrar a coisa de que falamos como pertencendo à situação comum aos interlocutores do diálogo."

${ }^{48}$ Em A metáfora viva, Ricoeur (2000) demonstra como, a partir da função metafórica da linguagem, a ficção é o caminho privilegiado da (re)descrição da realidade, ao passo que a poesia é aquela que, por excelência, opera o que Aristóteles chamava de a mimesis da realidade. A noção de mythos, enquanto
} 
problema fundamental da hermenêutica ricoeuriana. Se não se trata de uma intenção ou mensagem esperando ser encontrada por detrás do texto, tampouco de uma verdade que se revele na desmontagem das estruturas, então o que resta para ser interpretado? "Responderei: interpretar é explicitar o tipo de ser-no-mundo manifestado diante do texto" (Ricoeur, 2008, p. 65). Este "diante" frequentemente destacado por Ricoeur diz respeito à situação do compreender: uma projeção de coordenadas que se coadunam aos elementos ocasionais da situação onde nos encontramos. Com efeito, por meio dessas coordenadas se abrem, na realidade cotidiana, novas possibilidades de ser-no-mundo:

Ficção e poesia visam ao ser, mas não mais sob o modo do ser-dado, mas sob a maneira do poder-ser. Sendo assim, a realidade quotidiana se metamorfoseia em favor daquilo que poderíamos chamar de variações imaginativas que a literatura opera sobre o real (Ricoeur, 2008, p. 66).

Caso tenha ficado claro, até aqui, que o mundo-do-texto é a mediação pela qual compreendemos a nós mesmos em relação ao mundo, resta esclarecer como o compreender diante do texto ultrapassa a mediação para tornar-se articulação.

Em primeiro lugar, há uma objetivação típica do texto que não responde ao autor, e sim ao sentido que é aberto, instituído e instaurado pelo próprio texto. Por conseguinte, na contramão da pretensão moderna de compreender a si mesmo por intuição imediata, devemos dizer, com Ricoeur, ${ }^{49}$ que sempre nos compreendemos em relação a mediações simbólicas articuladas em obras — literárias, cinematográficas, filosóficas etc. O que saberíamos do amor, dos sentimentos éticos e, em geral, de tudo o que chamamos de "eu”, caso isso já não estivesse conjugado culturalmente?

Assim como a língua — que, ao articular-se sobre o discurso, ultrapassa-se como sistema fechado e realiza-se como proposição de sentido -, o próprio “eu”, ao ingressar no processo da compreensão, ultrapassa-se, enquanto discurso, pelas mediações que o veiculam.

[...] assim como o mundo do texto só é real na medida em que é fictício, da mesma forma devemos dizer que a subjetividade do leitor só advém a ela

\footnotetext{
“fábula”, adquire central importância ao percorrer tanto a ficção quanto a poesia para realimentar o real por aquilo mesmo que o constitui: as imagens, as aparências.

${ }^{49}$ Em O si-mesmo como um outro, Ricoeur (1990) delineia uma extenuante crítica à pretensão idealista de autossuficiência da consciência de si. A esta exaltação do cogito se opõe, a partir de Kant em diante, um cogito quebrado ou ferido - quebra esta que, para Ricoeur, sinaliza a apreensão de uma unidade muito maior, mesmo que nunca totalizável pelo sujeito: a unidade simbólica que se estabelece, em cada ação, em cada obra, entre o sujeito e o mundo.
} 
mesma na medida em que é colocada em suspenso, irrealizada, potencializada, da mesma forma que o mundo manifestado pelo texto. Em outras palavras, se a ficção é uma dimensão fundamental da referência do texto, não possui menos uma dimensão fundamental da subjetividade do leitor. Só me encontro, como leitor, perdendo-me. A leitura me introduz nas variações imagináveis do ego. A metamorfose, segundo o jogo, também é a metamorfose lúdica do ego (Ricoeur, 2008, p. 68).

Neste ponto, avançando na questão da articulação, já podemos ampliar as noções de "texto" e "obra" a todo medium que veicula, em maior ou menor grau, uma proposição de sentido: objetos, comidas, marcas, estilos de vida etc. Note-se que o distanciamento que Ricoeur sublinha entre a fala e o texto se mantém efetivo, embora mais sinuoso: se eu gravar em vídeo uma conversa minha, o que verei depois, no vídeo, será outra conversa. O simples fato de eu registrar de algum modo o que eu digo já causa uma objetivação tal que o sentido inicial torna-se outro para mim. Do mesmo modo, quando repetimos a leitura de um livro que já lemos, quando assistimos novamente a um filme que já vimos, nossa interpretação muda, ainda que minimamente, conforme a ocasião na qual nos encontramos. Algo similar acontece com nossos móveis, roupas, utensílios domésticos etc., que com o tempo decidimos trocar por coisas novas ou que, uma vez guardados, adquirem outra importância.

Em todos esses casos - gravar um vídeo, reler um livro, comprar uma roupa nova - estamos articulando as diversas mediações que nos perpassam. Não se trata de impor às mediações um novo sentido, e sim de expor-se a elas, assimilando e dialogando com a proposição de mundo que está em jogo em cada ocasião. Por isso que, em menor ou maior grau, estamos a todo instante articulando "textos" — quando escrevemos isso fica evidente, mas também quando estamos no trânsito, numa reunião de trabalho, num passeio com a família etc., há sempre uma série de proposições sendo articuladas. É preciso, portanto - e aqui reside uma das contribuições que pretendo traçar neste trabalho — , transferir, sob o prisma mesmo da hermenêutica, essa dinâmica de objetivação, que Ricoeur explorou no nível do texto, para o registro do design, conforme faço logo mais, após conceituar a "articulação simbólica".

Sintetizemos o nosso percurso. A recusa da "aparência" é paradigmática na tradição do pensamento ocidental, no qual prevalece religiosamente a oposição entre razão inteligível e "desrazão" imaginária. De um lado, o verdadeiro; de outro, o imediato. Sob a via trágico-nietzschiana, no entanto, o mundo "verdadeiro" coincide 
com o imediato, o aparente, o sensível, prescindindo assim de qualquer suporte idealista. O imaginário, o conhecimento e a razão humana não encontram em si nada mais do que expressões provisórias de ficções que se desenrolam continuamente, isto é, na compreensão de uma existência ao acaso, sempre em vias de sumir por definitivo.

A partir disso, assimilamos a tarefa hermenêutica: compreender para existir e existir para compreender. Melhor: compreender como modo-de-ser, mas também um modo de compreender em que mesmo a ideia de "existir compreendendo" não passe de sentido acrescentado ao real, que assim é imaginariamente organizado para nos parecer "factível". Nesse movimento, avançamos do discurso em direção à proposição de sentido e do par leitura-escrita em direção ao par mediação-articulação.

Daí que a principal contribuição de Ricoeur consiste na noção de mundo-dotexto, a proposição de sentido que se abre diante do texto, de modo que toda interpretação situe de imediato o interpretante in media res. Não obstante, a própria obra de Ricoeur é explicitamente descontínua, feita de "resíduos" de outras obras, construída em espiral, retomando de forma infatigável a tradição filosófica. Talvez sua originalidade seja justamente a de, uma vez assumidas e explicitadas as mediações incontornáveis que o conduziram, conseguir articular tais mediações para propor um novo sentido diante da tradição hermenêutica - tanto que, para expor sua proposta, imputei-me a necessidade de, antes, sintetizar o quadro genealógico de que ele se serve.

Resta então admitir que, no intuito de me servir da hermenêutica ricoeuriana para minhas proposições, enfatizei em sua obra alguns vetores em detrimento de outros. Meu recorte na questão da hermenêutica ignorou principalmente as reflexões de Ricoeur sobre a finitude e a fragilidade humana, que o encaminharam numa direção distante do pensamento trágico; creio ser necessário desvelar, brevemente, esse desfalque de minha parte. Em primeiro lugar, a herança da filosofia personalista o levou a crer numa transcendência negativa ("o homem é um ser que não coincide consigo mesmo") que não poderia ser apreendida nas malhas da narrativa. O legado de Husserl, por sua vez, aparece em Ricoeur como uma necessidade de redescobrir uma autenticidade do vivido, graças a uma fenomenologia aplicada a uma filosofia da vontade e da ação. Por fim, a valorização das noções de "atestação" e "humildade" veio a socorrer, na ética ricoeuriana, uma angústia herdada de Kierkegaard mediante certa "insuficiência" da vida humana - e é aí, parafraseando Kant, que o saber deve ceder lugar à fé.

Em suma, ignorei toda a obsessão meta-hermenêutica de Ricoeur em desmistificar a condição finita, frágil e sofredora do homem — o que faltou ao filósofo, 
sem dúvida, foi apenas abraçar totalmente sua própria teoria hermenêutica, o que o teria levado, quero crer, a afirmar alegremente a condição trágica da existência. De certo modo, assim como Kafka, Lacan e tantos outros, Ricoeur chegou a "olhar" para o trágico, mas enxergou nele apenas absurdo, inelutabilidade, irracionalidade. Esse detalhe talvez possa nos ajudar a recapitular, mais uma vez, a conceituação delineada no capítulo anterior: para Ricoeur, o saber trágico estaria além da compreensão humana, como um território que circunda a racionalidade que constitui a vida cotidiana. Haveria então uma esfera da razão e, exteriormente, uma esfera do trágico.

Ora, "a ideia de exterioridade é talvez o tema antitrágico por excelência, assim como é o tema fundamental da paranoia ('levaram'-me à perdição)” (Rosset, 1989, p. 67). Enquanto Ricoeur pensou em termos de duas esferas da realidade - trágica e nãotrágica -, aqui devemos pensar em dois modos de olhar para a realidade: trágico e nãotrágico. A diferença deixa de ser metafísica e passa a ser interpretativa (eis a assunção hermenêutica que faltou a Ricoeur). Vale pontuar que, quando Ricoeur fala de "trágico", ele se refere à conotação das tragédias gregas: destino, necessidade, força inelutável que comporta sua razão própria, interpretável apenas a posteriori. Quanto a esta concepção de trágico, o diagnóstico de Rosset (ibidem, p. 66) é contundente:

\footnotetext{
[...] confusão entretida por dois mil anos de má leitura dos Trágicos (na trilha de Aristóteles). Má leitura por intenção interpretativa: a necessidade sendo concebida como causa determinante (mesmo se sua origem é obscura), o destino como sistema de finalidade (mesmo se este deve dissolver toda finalidade de ordem antropomórfica: a busca da felicidade).
}

Essa diferença de concepção do "trágico" é útil, enfim, para precisar que a filosofia trágica - na qual Rosset elenca pensadores tão dispersos no tempo quanto os sofistas, Epicuro, Lucrécio, Montaigne, Spinoza, Hume e Nietzsche — "não é de modo algum uma filosofia da tragédia, disciplina que faz parte da estética e cujo objeto não seria outro que o de dar conta da severa Weltanschauung [visão de mundo] observada no conjunto das tragédias estudadas" (Hierro, 2001, p. 104). Sob um modo de olhar trágico, portanto, o trágico não reside somente nas tragédias gregas (suas estruturas e recursos), nos destinos, nas exceções e nas catástrofes, tampouco se restringe a esta ou aquela visão de mundo; pelo contrário, o trágico habita a esfera do cotidiano, está por toda parte, em tudo o que aparece e desaparece no real.

Posto isso, doravante passaremos a definir uma "hermenêutica trágica" aplicada 
à filosofia do design, por intermédio de certa epistemologia até aqui esboçada e de uma ontologia das imagens, isto é, dirigindo as noções de símbolo, ficção e criação estética para a questão da articulação simbólica. Por meio de exemplos pontuais, tento ilustrar como o mundo não cessa de ser configurado e reconfigurado, isto é, como não cessamos de assimilar o heterogêneo a partir de coordenadas imaginárias. Neste sentido, as noções de símbolo e ficção servem para mostrar que, ao estarmos "embrulhados" em histórias, o leitor que cada um de nós é não cessa de articular o mundo na perspectiva de uma hermenêutica simbólica — que é, argumento, antes de tudo trágica.

\subsection{HERMENÊUTICA TRÁGICA: símbolo, ficção e criação estética}

Vimos que hermenêutica não é apenas um esforço para compreender o que é a compreensão, mas sobretudo o que é este modo-de-ser - tendo a antropologia como outro nome para ontologia - que só existe compreendendo - tendo a epistemologia como premissa ontológica. Por isso que hermenêutica perpassa antropologia, ontologia e epistemologia, mas sempre prestes a invalidá-las em algum momento. Solucionemos o quanto antes, pois, a possível vinculação da hermenêutica com o trágico: penso que a inaptidão que não permite à hermenêutica aderir em definitivo a nenhuma disciplina sinaliza nada mais que o chão trágico que a assenta. Se ela não precisa, para se fazer valer, de nenhuma "razão maior", é porque ela remete a um solo "mais firme" que prescinde de toda referência a um conjunto de significações do qual dependeria.

De fato, esse solo permanece em suspenso nas teorias hermenêuticas, talvez não por uma questão de miopia ou cegueira, mas apenas para evitar confusão. Em outros termos, a dificuldade de distinguir e lidar com a fugidia semântica do "trágico" no contexto hermenêutico nos solicita demarcar, de maneira clara e plausível, qual é, afinal, o status da hermenêutica na visada trágica aqui considerada. O trágico aparece primeiramente expresso sob forma poética, na arte dramática denominada precisamente "tragédia" (Ésquilo, Sófocles, Eurípides). Em seguida, por derivação e sob forma conceitual, o trágico ampliou-se a um tipo de filosofia: "a afirmação da incapacidade humana para reconhecer ou constituir uma natureza; donde o caráter vão do pensamento, que não reflete senão suas próprias ordens” (Rosset, 1989, p. 104).

Nas ramificações desse percurso, vemos rastros não apenas de anacronismo, mas antes de polissemia. Por exemplo, sabe-se que Lucrécio falava em termos de "natureza" 
para excluir quaisquer conjecturas metafísicas, ao passo que, posteriormente, muitos filósofos reintroduziram nesse mesmo conceito tudo o que Lucrécio quis evitar. Essa inversão semântica de um mesmo conceito é operação bem conhecida desde os sofistas até as análises de Hume, Marx e Lenin. Só que nada impede, todavia, que compreendamos novamente que, se tudo pode ser dito "natural" é precisamente porque não há "natureza" das coisas, enquanto princípio universal e imutável. Ampliando ao registro hermenêutico: se tudo pode ser interpretado é precisamente porque não há o que ser interpretado - sendo um dos aspectos do trágico "o que se furta a toda tentativa de interpretação" (Rosset, 1989, p. 65).

Isso não implica, contudo, que se recuse a interpretar e, portanto, que se invalide a hermenêutica. A recusa do pensamento trágico não concerne ao ato de interpretar ou às interpretações produzidas, mas tão somente que haja algo a ser interpretado, isto é, um significado, uma ordem, um conteúdo inerente ao real. Com efeito, por "hermenêutica trágica" devemos entender apenas uma hermenêutica que, como a de Ricoeur, não pressupõe um conteúdo específico a ser interpretado, mas que, em vez disso, encare o compreender como um modo-de-ser - uma vez que "o trágico falado é preferível ao trágico silencioso" (Rosset, 1989, p. 30). Ao alinhavar nossa investigação a partir desse ponto de referência, quero pôr em relevo justamente esta dupla problemática que envolve a questão: um silêncio que fala e uma fala silenciosa. Respectivamente, estabeleço neste tópico uma descrição nítida e específica da ideia de uma "hermenêutica trágica" e concluo, no capítulo seguinte, pela aplicação de tal ideia no seio de uma articulação simbólica operada pelo design.

Pois bem, se uma das tarefas que nos impõe a hermenêutica é a de "fazer falar" o mundo, podemos começar aqui pela tarefa de "fazer passar o trágico do silêncio à fala" (ibidem, p. 29). Tal asserção poderia remeter à famosa análise de Bataille (1986) sobre Nietzsche, que é anunciado como fundador de uma filosofia sobre o "não-sentido", de um saber silencioso a que todos os saberes levam. Parece-me útil apontar aqui o duplo equívoco de Bataille: primeiro, a filosofia trágica não foi de modo algum inaugurada por Nietzsche - de acordo com Rosset (idem), ela já se encontra em Górgias, Lucrécio, Montaigne etc. —; segundo, essa ideia de "não-sentido" designa uma experiência absurda que, para Bataille, não poderia ser dita senão por um "brilhante solitário de nosso tempo". Pressupõe-se, portanto, que o trágico refere-se a uma visão que as pessoas em geral não possuem, ao passo que, conforme nos assegura Rosset (ibidem, p. $34)$, 
[...] a situação é bem precisamente o contrário: o saber trágico é o apanágio da humanidade inteira, com a única exceção de alguns intelectuais particularmente brilhantes, como Bataille. Os pontos-de-vista populares sobre o mundo são de maneira geral centrados sobre ideias de desordem, de acaso, de uma absurdidade, inerente a toda existência, que a expressão "é a vida" resume em todas as línguas e em todas as épocas; [...] O que autoriza muitos pensadores contemporâneos a negar, como Bataille, a universalidade do saber trágico é o fato de que o trágico não fala, ou quase não fala. Conclui-se daí que não há "consciência" trágica [...] em quase todos os homens. Esta concepção superficial, que encontra numerosos ecos na filosofia contemporânea, resulta de uma assimilação, ou antes de uma confusão (esta assimilação não sendo, precisamente, "pensada" enquanto tal), entre o não falado e o não pensado - por vezes batizado "impensado".

Aos olhos daqueles que recusam os pensamentos de tipo trágico, o trágico somente começaria quando não houvesse mais nada a dizer nem a pensar. Esta noção de trágico como absurdo, como um discurso detido, um pensamento imobilizado, procede de uma fé metafísica no valor das ideias tais quais se exprimem, como se o que é dito fosse, para a pessoa fala, uma formulação exata daquilo que ela é capaz de pensar. "Também aí, como sucede frequentemente, a unidade da palavra não garante a unidade da coisa" (Nietzsche, 2000, § 14, p. 25). Como já pontuamos, o trágico nunca é a exceção de uma pretensa ordem racional, normal, harmoniosa. Mas sendo a língua um recurso racional e necessariamente estruturado, e sendo o trágico aquilo que não se pode definir a partir de referências como causa ou necessidade, como falar do trágico?

Ora, já estamos falando. Quando falamos de acaso, por exemplo, escolhemos o conceito mais próximo da recusa de conceitos; quando falamos de "silêncio", tentamos dar voz a esta ausência original de referenciais. A questão é que todas as palavras, ideias, representações, já se inserem no trágico e não o contrário. Nomear é definir, definir é determinar uma natureza, mas nada possui uma "natureza". Trata-se aqui do velho problema de saber se a desordem não se pode conceber senão a partir da ordem — tese de Bergson —,${ }^{50}$ ou se é possível falar de desordem e de acaso originais — como fez Lucrécio, atribuindo ao acaso a paternidade de toda organização, a ordem sendo apenas um caso particular da desordem. Mais precisamente, no entanto, trata-se antes de

\footnotetext{
${ }^{50}$ Em A evolução criadora, Bergson (2006, p. 242) define a negatividade da noção de desordem: "a realidade é ordenada na exata medida em que satisfaz nosso pensamento. A ordem, portanto, é um certo acordo entre o sujeito e o objeto."
} 
uma sobreposição semântica: aquilo que Bergson chama de "desordem" (irracionalidade, falta de sentido) não equivale ao que Lucrécio chama de "acaso", esta força anterior a toda ideia de ordem ou desordem. ${ }^{51}$

Disso importa reter que toda interpretação, assim como tudo o que existe, é sempre "casual", no sentido de produto do acaso, donde uma "hermenêutica trágica" exclui ao mesmo tempo a ordem das determinações e suas exceções, a ordem das necessidades e suas contingências e, de maneira geral, as ideias de ordem e de desordem. Se há uma ideia de ordem, esta depende daquilo que também tornou possível a ideia de acaso: uma hermenêutica que a precede e engendra. Assim, toda e qualquer visão de mundo é igualmente válida sob o viés de uma hermenêutica trágica - mesmo aquela que leva em conta certo universalismo ou determinismo, porque não vemos nela a expressão particular de uma ordem geral assim "revelada", mas apenas uma manifestação casual de organização que não remete a nenhuma ordem exterior a ela.

Talvez o primeiro exemplo característico de uma hermenêutica trágica seja dado, na história da filosofia, pela sofística antiga que, graças a Platão, foi relegada à expressão pejorativa de "retórica" - em seu livro sobre Górgias, Platão descreve o termo rhetorike como falso saber, uma arte a serviço da opinião, em contraposição à razão dialética, que estaria a serviço da verdade. Sob o viés sofístico, porém, a razão não fornece qualquer verdade sobre a realidade, possuindo apenas uma função emotiva - fazer passar o trágico do silêncio à fala. Era assim que alguns sofistas defendiam a persuasão por si mesma: só era verdadeiro aquilo que persuadia, contrariamente ao que apostava o discurso filosófico (socrático-platônico), acantonado em sua frieza, em sua dificuldade em persuadir, apostando sempre que a verdade prescindiria de qualquer tipo de persuasão e, somente aos virtuosos, impor-se-ia por si mesma.

A filosofia sofística, negadora da verdade, está então centrada sobre uma teoria da ocasião: tudo o que sobrevém é como uma filosofia em miniatura que a retórica consiste em apreender no momento oportuno, isto é, no único momento possível. Tomando em conta o momento oportuno (kairós), portanto, a arte de persuadir pressupõe também que a doxa, nossa opinião incerta e inconstante, seja a única forma de conhecimento possível. O contínuo desdém operado pela tradição fílosófica em

\footnotetext{
${ }^{51}$ É interessante mencionar a introdução que Bergson redigiu ao De rerum natura de Lucrécio: nela, a chave de leitura é designada pela monotonia lucreciana que enxerga certa uniformidade na natureza, como uma ordem de leis fixas e imutáveis. Para Rosset (1989, p. 130), o tédio que ali está em questão "não é o tédio de Lucrécio diante da natureza, mas o tédio de Bergson diante da natureza descrita por Lucrécio. Reação de metafísico muito justa e profundamente frustrada pela leitura do De rerum natura".
} 
relação aos sofistas ${ }^{52}$ não nos deve impedir de ver o modo como essa arte remete a uma hermenêutica trágica: tudo que acontece, tudo que existe, não sobrevém senão uma vez e não pode ser apreendido senão uma vez; são ocasiões que existem apenas em um tempo, em um lugar, para uma pessoa, e cuja experiência única dota cada instante das características de um jogo, aquele de ser-para-compreender.

Se conseguimos dar conta, até aqui, de mostrar como o silêncio trágico pode "ser falado", poderemos avançar nos elementos hermenêuticos conjugados neste silêncio que fala, isto é, nunca como extração de um conteúdo prévio. Vimos que "mediação" é tudo aquilo que traz uma proposição de mundo, enquanto "articulação" diz respeito à reação perante tal proposição, a objetivação que faz abrir a proposição de mundo diante da mediação. Se o compreender sempre se dá em relação a mediações simbólicas, ao mesmo tempo ele nos solicita uma articulação: nossa lida com uma proposição de mundo nunca é passiva ou transparente, mas sempre analógica, ou seja, procedendo por analogia a outras proposições.

Com efeito, a hermenêutica trágica só aparece com veemência quando as mediações, libertas da tutela dos conteúdos inerentes e das intenções subliminares, adquirem autonomia simbólica e aguardam uma articulação por parte do "leitor". Enquanto as mediações se constelam de acordo com cada ocasião, a articulação corresponde ao momento oportuno. Daí que a analogia, esta lógica indireta e não causal, movimenta nossas articulações: penso em algo aqui, depois acrescento outro pensamento ali, e logo acolá, sem que exista relação direta entre esses pensamentos. É nesse sentido analógico que Ricoeur (2000) caracterizou a hermenêutica como uma modalidade poética: um desejo de organizar e de (re)descrever o mundo não de forma lógica, mas analógica, condensando em analogias a maior significação possível.

É preciso assinalar, neste ponto, que tal noção de analogia nada tem a ver com aquilo que Aristóteles designava como "igualdade de relações", como uma unidade que seria proporcional (analógica) a determinado conjunto de coisas - pressupondo, pois, a separação entre a essência e a realidade à qual ela se refere. A essa concepção, herdada pelas tradições escolástica, tomista e cartesiana, devemos contrapor a noção spinozista de "modo" ou "expressão": um modo de ser e agir no mundo, em vez de indicar uma

\footnotetext{
${ }^{52}$ Desprezo não apenas aos sofistas, mas aos pensadores antimetafísicos de maneira geral - cujas propostas o filósofo francês Michel Onfray se dedicou a recuperar nos seis volumes de sua Contrahistória da filosofia. O filósofo barroco Balthasar Gracián (2009), por exemplo, legou-nos uma proposta rigorosa: à ideia de ser, Gracián opõe a de parecer; à substância, a ocasião; ao saber, a prudência, que é a arte de aparecer e aproveitar o tempo oportuno. Enfim, a arte sofista sobreviveu aos séculos, sempre como "exceção", mas obtendo considerável impacto nas teias socioculturais de cada época.
} 
aparência por meio da qual uma essência se expressa, ocorre em virtude de outros modos, conjugados em determinada relação (Spinoza, 2007). Sob esse viés, não havendo "graus" de realidade, a analogia é, conforme argumenta Gilbert Durand (1995, p. 7-17), aquilo que apresenta, que faz aparecer um modo de ser, e não aquilo que representa um objeto ausente que estaria por trás de uma expressão.

A analogia constitui, não obstante, um dos principais aspectos do "símbolo" noção necessária para falarmos, a seguir, de uma "articulação simbólica". O símbolo remete sempre à união de duas partes, como no alemão sinnbild (sentido mais forma) ou no grego symbolon (reunir partes), concernindo uma expressão (imagem, palavra, objeto etc.) polissêmica, sempre em aberto, cujo sentido não vem colado de imediato, mas é produzido por uma questão de analogia e recorrência. A palavra "fogo", por exemplo, pode significar o fenômeno físico que é o fogo, mas também pode, por uma questão de recorrência simbólica, remeter indiretamente a uma divindade, um sentimento, um tipo de situação, enfim, a outro significado que não o denotativo.

Enquanto mediação, pois, o símbolo desempenha uma função semelhante às da alegoria, da metáfora e da parábola, que também jogam com analogias e sentidos figurados. O que distingue o recurso simbólico desses outros recursos é a amplitude da analogia que, por meio dele, permanece em aberto. De acordo com Ricoeur (2000), embora o cerne semântico do símbolo tenha como base o sentido operante da metáfora, há algo no símbolo que resiste à metáfora: enquanto esta está ligada ao discurso e à linguagem na qual se insere, o símbolo está ligado a outros símbolos e, assim, não se esgota nem na linguagem nem no discurso, mas depende de uma "não-estrutura" que lhe escapa. Qual seja, é a analogia mesma que mantém os símbolos em movimento, instaurando uma função simbólica de mediar as duas esferas em que o imaginário se manifesta: na esfera discursiva (retórica) e na esfera das imagens (poética).

Daí que uma "articulação simbólica", finalmente, implica não apenas pensar simultaneamente em discurso e imagem, que se integram numa lógica simbólica e analógica, mas também na redescrição (hermenêutica) do mundo que se abre por meio da articulação dessas mediações simbólicas. A esta definição é preciso acrescentar duas implicações: (1) que a força do imaginário não existiria se o "compreender" não estivesse ele mesmo enraizado no mundo, sempre prévio a qualquer experiência e a qualquer explicação; (2) que o símbolo é um exemplo privilegiado de "mundo-do-texto" pelo qual o mundo pode ser descrito e reescrito - processo este a que recorremos o tempo todo não somente para compreender a realidade na qual nos inserimos, mas 
também para nos reinserirmos e nos situarmos nela.

Essa correlação entre reescrever o mundo e reinserir-se nele põe em evidência a recursividade que caracteriza a articulação simbólica, processo central a uma hermenêutica trágica. Recursividade que, assegurando a dinâmica do símbolo, consiste em construir por cima das ruínas do literal ou da razão transcendental a veemência do compreender que se mostra agora sob a forma analógica de um "como se". 53 É aqui que aparece a segunda questão fundamental para uma hermenêutica trágica: a noção de "ficção" que, como vimos, mantém o real e o imaginário interligados e que, por conseguinte, abre o cruzamento entre ontologia e hermenêutica.

Ficção é criação de mundo, isto é, a realização de uma articulação simbólica. Deve ser entendida, portanto, não como modalidade oposta à de "não-ficção": primeiro, porque o discurso não-ficcional, justamente por declarar-se como tal e nem por isso deixar de inventar o próprio "fato" que se propõe a evidenciar, talvez seja o mais ficcional que existe; segundo, porque há, nos dois "lados" do texto dito não-ficcional, uma predisposição mínima de alguém em refletir-se e ver-se refletido, por comparação e analogia, antes mesmo de se saber do que se trata o texto, quem o escreveu e quem irá lê-lo. Nesse sentido, toda proposição de mundo é ficcional porque é sempre fruto de um processo de criação. Seriam também a poesia, a música, a fotografia, a dança etc. formas de ficção? Sem dúvida, ainda que num grau diferente em relação a, por exemplo, um filme ou um romance.

É nesse sentido que Ricoeur (2000) contrapõe a narrativa como obra à metáfora como recurso discursivo, levantando então a questão: não será a metáfora uma obra em miniatura, e a narrativa, uma obra metafórica? Vejamos como, antes disso, o autor resolve aquele problema de haver no símbolo algo que resiste à metáfora: esta passa a ser redefinida como recurso analógico dentro do qual se deposita o poder simbólico. Passa-se a considerar, assim, que as metáforas são as "superfícies semânticas" dos símbolos.

A metáfora apresenta-se, então, como uma estratégia de discurso que, ao preservar e desenvolver a potência criadora da linguagem, preserva e

\footnotetext{
${ }^{53}$ Somos aqui remetidos de imediato à Filosofia do "como se" de Hans Vaihinger (2011), que em meados do século XX propôs uma epistemologia a partir do princípio da ficção: nós nos comportamos "como se" o mundo correspondesse às ficções, sobretudo científicas, que criamos para explicá-lo. Vale pontuar que, no entanto, o filósofo neokantiano era avesso ao ceticismo nietzschiano, tomando a ficção apenas como solução não-racional e pragmática para questões que não têm respostas racionais (quais sejam, as de um idealismo transcendental).
} 
desenvolve o poder heurístico desdobrado pela ficção. [...] a metáfora é o processo retórico pelo qual o discurso libera o poder que algumas ficções têm de redescrever a realidade. [...] Dessa conjunção entre ficção e redescrição concluímos que o "lugar" da metáfora, seu lugar mais íntimo e mais último, não é nem o nome, nem a frase, nem mesmo o discurso, mas a cópula do verbo ser. O "é" metafórico significa a um só tempo "não é" e "é como" [portanto, "como se"] (Ricoeur, 2000, p. 13-14).

Se a metáfora nos permite compreender e enriquecer a superfície semântica do símbolo, este último mergulha "mais fundo" no significado, convocando uma ficção em potencial - quando digo, por exemplo, que "amor é um fogo que arde sem se ver", tal analogia metafórica solicita algo que confirme seu significado, portanto uma narrativa, uma ficção. É assim que, retomando a questão dos diferentes graus de ficção, podemos estabelecer, como Ricoeur o fez entre narrativa e metáfora, níveis topológicos de implicação ficcional: a fotografia como uma poesia em miniatura, a poesia como uma ficção fotográfica e assim por diante. Embora Ricoeur tenha privilegiado a noção de "narrativa" como manifestação ampla do símbolo, aqui privilegio a noção de "ficção" por esta abarcar, a meu ver, não apenas o registro discursivo, mas também e diretamente o das imagens - por onde se expressa, como mostro adiante, o design.

Mais especificamente, o sentido da ficção parece abarcar uma dimensão estética, tal como Nietzsche (2001, § 299) a concebia: "queremos ser os poetas da nossa vida e, em primeiro lugar, das coisas mais pequenas e comuns." A vida como obra de arte, com efeito, inscreve-se como ficção, a ficção do amor fati, "amor pelo destino" — não como um futuro preestabelecido, mas como um sentido que dou à minha história, somatória das escolhas que faço com o fortuito da existência. Logo, uma ficção apresenta visões de mundo, afetos projetados e introjetados na relação do homem com o mundo, podendo assim ser veiculada pela religião, pela ideologia, pela política; mas sua força jamais se reduz a tais dimensões da vida, pois toda ficção é vivida no cotidiano, isto é, sempre na partilha de existências individuais e conforme cada ocasião.

“[...] nós somos, até a medula e desde o começo - habituados a mentir. Ou, para expressá-lo de modo mais virtuoso e hipócrita, em suma, mais agradável: somos muito mais artista do que pensamos" (Nietzsche, 2005, § 192). Essa arte de sujeitar o mundo a uma ficção, que para Nietzsche constitui o âmago da relação do homem com o mundo, uma relação facilitadora, torna-se sabedoria quando reconhecida conscientemente. Donde o processo formativo constitui um diálogo com a ficção, 
embora nem sempre de maneira criativa - daí a importância formativa da articulação simbólica. Por ora, ainda devemos compreender a noção de "criação estética" que conjuga as ficções e caracteriza a articulação simbólica. Esquematicamente, pois, assimilemos que:

- Hermenêutica trágica é o "silêncio que fala", ou seja, o compreender que privilegia o momento oportuno em detrimento de um sentido fixo;

- Símbolo é a mediação hermenêutica que opera por analogia e ultrapassa a esfera discursiva (abarcando a das imagens);

- Articulação simbólica é o processo hermenêutico de redescrever, à maneira dos símbolos, o mundo, para compreender-se em relação ao mundo;

- Ficção é o recurso próprio da articulação simbólica, agenciando a criação estética pela qual se instauram as proposições de mundos.

Cada uma dessas noções já está imbricada nas demais e, ao mesmo tempo, guarda em si certa suficiência semântica que prescreve, em larga medida, o que me refiro por "criação estética". Entretanto, a importância desse conceito surge à medida que a apreensão detalhada dos demais conceitos, acima listados, não garante que os identifiquemos, de maneira clara e abalizada, no conjunto do horizonte hermenêutico e trágico em que se encontram. Em outros termos, é preciso "aplicar" todas essas noções para vê-las "funcionando". Para tanto, logo mais analiso alguns exemplos pontuais, mas em todo caso é finalmente o conceito de "criação estética" que pode contextualizar os demais. Comecemos pela questão: o que significa o belo? Pensar uma criação estética é a mesma coisa que pensar o belo como ato de criar?

O belo não é nem artifício nem natureza, sendo primeiramente acaso. Daí resulta que o ato humano que culmina na criação de belas formas não é irracional, como diz Platão no Íon, mas casual, como o são todos os atos; e além do mais ele não é exatamente criador, se se entende por criação uma modificação trazida ao estatuto do que existe: nesse sentido - que é aquele habitualmente reconhecido à expressão "criação estética" — toda criação é impossível (Rosset, 1989, p. 183).

O decreto de que "toda criação é impossível" é somente polêmico e insidioso do ponto de vista por ele denunciado: aquele da criação como excepcional ação de 
transformar o mundo, pressupondo agentes criadores como únicos aptos a fazê-lo. Com efeito, essa faculdade "criadora" é entendida, nestes termos, como pretensa aptidão em transcender o acaso, isto é, como capacidade de ultrapassar a sorte oportuna para conceber deliberadamente coisas belas. É nesse sentido que a severidade de Platão em relação aos artistas (no livro X da República) não se referia tanto ao ato mimético, mas à intenção de imitar um modelo que seria propriamente inimitável. Qual seja, algum que tornasse coerente o sentimento agradável que nasce em todas as ocasiões belas, como uma necessidade sem a qual não perceberíamos o belo.

Em seu famoso diálogo Hípias maior, Platão relata-nos que, ao ser indagado por Sócrates sobre o que é o belo, Hípias responde que o belo é uma bela jovem. O sofista então é julgado como imbecil, por ser incapaz de compreender o simples problema que lhe foi posto, o da generalidade: quer dizer que uma bela jovem explica tudo o que há de belo? O que não consta no diálogo, mas que provavelmente teria dito Hípias (que, não à toa, era um filósofo de grande renome em seu tempo), é que o belo não é nada mais que uma bela jovem, tal como aparece em um certo momento, aos olhos de um certo homem. Ou seja, não há generalidade alguma uma vez que "o" Belo, enquanto princípio geral, não existe - o que existe é uma infinidade de circunstâncias, de encontros, de ocasiões que por acaso mostram-se agradáveis.

Logo, a recusa do sofista não é em compreender, mas antes em admitir a hipótese da generalidade: a ideia de "uma bela jovem" segue a lógica sofística na qual "uma" prevalece sobre "todas". Similar é a recusa daqueles artistas que não fazem muita questão de explicar seu processo criativo: independente de qualquer arrogância, muitas vezes não há o que explicar além de "não sei o que fiz, apenas comecei e terminei”. Mais escandalosa ainda é sua ausência de necessidade: tal como um riso que nasce sem motivo algum, a obra aparece entre a infinidade de combinações de formas visuais, sonoras ou verbais, e a singularidade das circunstâncias que a envolveram. O paradoxo da obra bem-sucedida, pois, reside em seu incontornável aspecto de acidente: num momento antes, uma folha em branco potencialmente desastrosa; num momento depois, a revelação a posteriori de uma improvável expressão que a precedia.

Igualmente sem justificativa, o artista quer ser recompensado: com um sorriso que não saiba dizer exatamente por que sorri. Por mais difícil que possa ser recusar uma necessidade, motivação ou causa explicativa, a insuficiência disso mediante a obra é o que define a experiência estética - mesmo que tal insuficiência sirva como invólucro metafísico de um modelo inimitável. Por conseguinte, se não há necessidade ou 
explicação à altura da obra, dois raciocínios são possíveis: ou não há nada a imitar (o que equivale, em última análise, a um modelo inimitável) ou toda imitação implicará necessariamente modificação e acréscimo. Se, no primeiro caso, a intenção inicial é negada de antemão, será apenas no segundo caso que o artista estará em plenas condições de aprovar sua atividade: o que se modifica e se acrescenta é somente acaso, cuja diversidade solicita imitação para ser reconhecida e aprovada. Dito em outros termos, toda criação é imitação do que existe, isto é, só acrescenta acaso ao acaso.

Tomemos dois casos exemplares, um de negação e outro de aprovação da atividade artística. O primeiro é Leonardo da Vinci, ao menos de acordo com duas análises: a de Freud em Uma lembrança de infância de Leonardo da Vinci (1910), e a de Paul Valéry em Introdução ao método de Leonardo da Vinci (1895). ${ }^{54} \mathrm{Na}$ perspectiva freudiana, sublimação significa basicamente a transferência das energias sexuais para atividades não sexuais, como a criação estética. Para expor tal teoria, Freud descreveu da Vinci como um caso de "semi-sublimação" que, por conta de uma obsessão estritamente intelectual, culminou em frustração.

Por sua vez, Valéry é complacente ao caráter "penoso" da arte de da Vinci, que neste caso se justifica por uma romântica necessidade de buscar razões para aquilo que, na vida, não se obteve explicações satisfatórias. A famosa afirmação de da Vinci de que “arte é coisa mental” sintetiza sua renúncia em relação ao acaso, sua incapacidade de aceitar suas tendências homossexuais e, de maneira geral, sua escolha de não celebrar a vida pela arte, mas de repetir nela sua insatisfação. De fato, buscar "razões maiores" $n a$ e pela arte é inconciliável com reconhecimento do acaso. Mesmo que tenha criado e descoberto coisas revolucionárias, Leonardo da Vinci recusava-se a criar porque não admitia o acaso do que existe e do que se cria.

Exemplo oposto é o fotógrafo estadunidense Soul Leiter, cujo olhar voyeur, na contramão da fotografia urbana entre 1940 e 1950, capturava momentos delicados, simples e calmos no turbilhão de Manhattan. Para ele, cada fotografia não passava de um lance de dados que, parafraseando Mallarmé, “jamais abolirá o acaso”. Nessas condições, criar implica renunciar qualquer necessidade, recusar qualquer razão em proveito de um ato contraditório por excelência: introduzir um elemento de modificação (acaso) num conjunto cuja automodificação não é modificável (acaso). Pressuposto: nada foi criado, nem é suscetível de ser criado, seja pela mão do homem ou de deus, que

\footnotetext{
${ }^{54}$ Cf. (respectivamente) Freud, 1970, p. 55-124, e Valéry, 1998.
} 
não seja por uma questão de acaso. Consequência: a aceitação da impossibilidade, assim reconhecida, da criação, é condição necessária e paradoxal da criação estética. Vejamos como tal premissa aparece implícita no discurso de Leiter (2013, p. 16):

I must admit that I am not a member of the ugly school. I have a great regard for certain notions of beauty even though to some it is an old fashioned idea. Some photographers think that by taking pictures of human misery, they are addressing a serious problem. I do not think that misery is more profound than happiness. ${ }^{55}$

Fico tentado a dizer que a motivação de Soul Leiter era a de perdoar os prazeres da vida pelo fato de não serem necessários. Ocorre que nem isso importa: quaisquer que fossem suas razões, nada lhe impediu de criar por acaso (assim como não impediu da Vinci). De qualquer maneira, pois, não é que a criação seja de fato impossível. É que o acaso que a possibilita solicita-nos um consentimento: criar implica acrescentar acaso ao acaso e, portanto, nada criar. Donde podemos concluir que a faculdade criadora é indissociável da aprovação do acaso — ou de uma "vontade de sorte" (volonté de chance), como foi traduzida ao francês a noção nietzschiana de "vontade de poder" sendo a ação de criar nada mais do que ir ao encontro do acaso (ao invés de dominá-lo ou transcendê-lo, como queriam da Vinci e Valéry).

Poderíamos listar uma miríade de artistas que se alinham a esta mesma postura trágico-alegre de Soul Leiter - como o pintor barroco Johannes Vermeer, o compositor Erik Satie, o romancista Milan Kundera, o cineasta Woody Allen -, mas por ora cumpre determo-nos a sintetizar tal implicação de "criação estética". Em última análise, criar é apenas a expressão de um "gosto", uma capacidade de discernir no acaso dos encontros aqueles que nos são mais agradáveis. É nesse sentido que a própria noção de “criação" perde relevância, pelo menos em relação a duas outras noções: a de retenção (reconhecer o momento agradável não antes e nem depois, mas em seu instante mesmo, como que "em queda livre") e a de antecipação (por experiência de retenção, manter-se preparado para os bons encontros, assimilando métodos e técnicas para tanto). Não se trata de desvalorizar toda intenção de criar, e sim de admitir sua dinâmica de ficção e

\footnotetext{
${ }^{55}$ Optei por não traduzir esta citação por conta da contundência da língua inglesa que faz uma fala como esta não se deixar traduzir em sua simplicidade. Traduzo livremente: "Devo admitir que não faço parte da 'escola da feiura'. Tenho grande estima por certas noções de beleza, ainda que para alguns isso já esteja ultrapassado. Alguns fotógrafos pensam que, ao fotografarem a miséria humana, estão lidando com um problema sério. Eu não acho que a miséria seja mais profunda do que a felicidade.”
} 
articulação, tecendo assim uma sensibilidade criativa.

O que quer dizer tal sensibilidade? Não uma inocência, pureza ou qualquer outra idealização do olhar, mas uma disposição constante de afrontar um mundo indecifrável, muitas vezes desagradável e que continua longe de ser previsível. Particularmente tomo aqui a liberdade de recorrer, brevemente, ao recurso narrativo em primeira pessoa —, dar aula no lugar onde eu fui aluno ${ }^{56}$ tem sido um estranho contexto para tal sensibilidade criativa: percebo-me sozinho entre estudantes que já não me são próximos e que, no entanto, parecem vagamente cativados. Em contrapartida, uma pequena cena significativa: todos os dias, desde quando eu era aluno, sento-me num banquinho do pátio, na hora do intervalo, para tomar café. E sempre vejo um professor antigo, não sei de qual curso, sentado no banco da frente. Nunca falei com ele. Recentemente, ao terminar o intervalo, ele levantou a mão como sinal modesto de cumprimento; respondi com o mesmo gesto, que passou a repetir-se desde então.

Não cesso de ver, nessa mão levantada, o mesmo sinal que faço a meus alunos, um gesto distanciado talvez pela idade, talvez pela incompreensão ou talvez pelo mero semblante de um professor que não tem nada a dizer a não ser esta mensagem: estou longe de você, não sei como me aproximar, mas novamente estou aqui, e sei que você está aí. O que vejo nessa mão levantada é a beleza de estar num lugar que se distancia cada vez mais, um lugar que não posso nem reviver nem restituir, mas no qual permaneço. Confesso que aqui me "inspirei" numa cena de $O$ cisne, um romance de Gudbergur Bergsson, na qual acrescentei uma música da banda Our Griffins.

Quer dizer, por meio da leitura de um livro, somada à fruição de uma música, tentei operar uma articulação simbólica: coloquei-me como protagonista de uma ficção que coincide com minha vida, uma ficção que serve para eu compreender a mim mesmo compreendendo o mundo - e aqui servindo também para ilustrar a criação estética obrada na articulação simbólica. Assim, podemos finalmente responder àquela questão que deixei em aberto: pensar uma criação estética não é a mesma coisa que pensar o belo como ato de criar (como algo que transcende o acaso), porque o belo é apenas "uma bela jovem" (ocasião agradável) e criar significa nada criar (somar acaso ao acaso), o que implica saber ir ao encontro do acaso.

Criação estética concerne, enfim, "enxergar" o acaso. Enxergar nas obras de outrem tudo o que se passa em nossa vida, enxergar nos encontros e ocasiões tudo o que

\footnotetext{
${ }^{56}$ Em 2015 tornei-me professor adjunto no Departamento de Design da UFPR. Leciono principalmente em disciplinas de desenho e ilustração.
} 
tomamos emprestado de outrem e, uma hora ou outra, enxergar no "papel" uma obra que ainda não está ali. Com isso, criação estética também remete à expressão de um "gosto", ou àquilo que Deleuze (2012) designa por "estilo", isto é, o que produz a diferença dentro de um conjunto de valores semelhantes. Tal acepção de estilo remete, ainda, ao que Spinoza (2007) denomina "expressão": não a manifestação de uma essência, mas somente um modo particular de ser e agir no mundo. Essa expressão só ocorreria no seio de uma "ética da alegria" que amplia o poder da ação — a conduta que rege as ações estando sempre em movimento, sempre composta de diferenças que dependem da situação — , donde a própria ética baseia-se na estética.

Pensada então de modo inerente ao "viver a vida" - como uma obra de arte, conforme antecipamos —, a criação estética adquire especial relevância na Educação, embora possa remeter a determinado mantra dos educadores: "o caminho certo só existe no caminhar em si." Não é o caso de opor-se a tal enunciado - até porque sua abertura interpretativa é quase infinita —, mas por vezes ele denota certo ascetismo, no sentido de que basta continuar caminhando (ou buscando autossuperação, conhecimento, iluminação) para simplesmente sair do lugar. Ora, sair do lugar não significa nada. Assim como autossuperação, evolução espiritual, "mudar pelo mudar".

Se toda ficção só faz sentido à medida que a vivemos, qualquer orientação ética, em si mesma, não possui importância alguma — senão conforme esta ou aquela ocasião, e não de acordo com uma moral fixa. Caso essa dimensão estética não esteja em primeiro plano, perdemos de vista o preceito trágico da articulação simbólica e logo acatamos uma verdade qualquer. Isso fica claro quando alguém decreta, por exemplo, que o consumo e os constructos da indústria cultural nunca podem levar a uma vida como obra de arte, uma vez que tais elementos nos oferecem ficções prontas, inautênticas, que nos alienam das relações de dominação que os ordenam.

E quem determina qual é a ficção autêntica e a mentirosa, a mais fácil e a menos alienante? Por que um ideal pré-fabricado não pode vir a instaurar uma obra de arte? Penso que demonizar esta ou aquela "estetização" da vida implica não admitir outras ficções que possam concorrer com a única "correta" que assim se tenta promover. Implica desaprovar, enfim, o mundo onde se vive. É esse o argumento adotado por Nietzsche (2007, p. 15) em sua segunda "tentativa de autocrítica" de $O$ nascimento da tragédia, ao julgar que, contra o ascetismo schopenhaueriano que percorre esta sua primeira obra, seria necessário ainda não apenas "ver a ciência com a óptica do artista, mas a arte, com a da vida". 
Aderir esteticamente às ocasiões, por sua vez, não significa defender cegamente uma ordem social vigente, tampouco subvertê-la (transgressão é uma ficção constituinte daquela que se quer transgredir). Trata-se de conseguir lidar, articular e afirmar criativamente a tensão, sempre insolúvel, entre ficções que se contradizem e que porventura se opõem à nossa ficção — o que passa longe da moral ascética do esclarecimento, cujo princípio básico é o de ignorar as diferenças por meio de uma conduta fixa que se coloca "acima" de outros modos de existência. Daí que, na Genealogia da moral, Nietzsche (1998, III, § 25) elege a arte como único antídoto possível ao ascetismo e ao niilismo dele advindo.

Feitas essas considerações preliminares no que concerne o âmbito da Educação - a ser retomado no próximo capítulo — , resta-nos revisar as noções propostas no tópico vigente, só que agora as tomando em conjunto. Sob a forma de três análises pontuais, viso a seguir demonstrar, numa espécie de "aplicação conceitual", que a instância ou princípio maior daquilo que denominei "hermenêutica trágica" é o processo de articulação simbólica, noção esta que não se limita a nenhum campo específico de criação, mas perpassa cada ser-no-mundo.

Primeiramente, analiso o filme Sr. Ninguém (Mr. Nobody) para investigar de que maneira a temporalidade (experiência temporal) é sempre ficcional. Em seguida, aprofundo essa mesma questão na obra Em busca do tempo perdido. Por fim, seleciono o filme Sinédoque, Nova York (Synecdoche, New York) para abordar a morte como forma de articulação simbólica sobre a vida. Com isso pretendo estabelecer condições de seguir adiante, pela mesma via conceitual-metodológica, na defesa da performance da ideia de articulação simbólica a partir do design, defesa que faço no capítulo 4.

\subsubsection{Análise de Sr. Ninguém: a ficção em função do acaso}

Primeira questão pertinente: em que medida a ficção, por implicar um mínimo de "fingimento", não acaba por negar ou distorcer o real? Uma resposta interessante pode ser extraída do filme Sr. Ninguém (Jaco Van Dormael, 2009). Numa época de seres humanos imortais, o protagonista Nemo Nobody é o último dos mortais, e sua memória "primitiva" é objeto de estudo e curiosidade popular. Ocorre que Nemo descreve uma miríade de versões diferentes e contraditórias entre si, como se ele tivesse vivido todas as possibilidades para cada decisão que ele tomou ou deixou de tomar no 
passado. A interpretação mais pragmática é a de que essa memória contraditória resulta da incapacidade de Nemo de tomar decisões - no fim do filme, ele comenta com um jornalista que ambos (ele e o jornalista) não existem, pois estão na mente de uma criança (o próprio Nemo) que está sendo forçada a fazer uma escolha impossível: partir com a mãe ou permanecer com o pai depois de uma separação.

Minha interpretação é outra: aquilo que torna contraditória sua memória é sua singular capacidade de escolher todas as possibilidades. Como ele faz isso? Escolhendo esquecer o que de fato foi escolhido. "Esquecer é uma necessidade. A vida é uma lousa, em que o destino, para escrever um novo caso, precisa de apagar o caso escrito" (Machado de Assis apud Almeida, 2015b, p. 181). E, à medida que se esquece disso, todas as possibilidades são articuladas. É uma espécie de radicalização da articulação simbólica: fingir o que poderia ter sido sem se preocupar com o que de fato foi. Fingir não como um pretexto previamente pensado, e sim como orientação incontornável da ficção. Mas perder de vista o que de fato aconteceu não seria uma forma de negar a realidade, um consolo ilusório para um passado inconsolável?

Não vejo nada sendo negado ou consolado nessa história. As tais "escolhas impossíveis" que permeiam o enredo não indicam que o protagonista nunca escolheu nada, como se ele ainda estivesse preso a antigos dilemas que turvariam sua memória. Pelo contrário: a impossibilidade da escolha implica um lúcido reconhecimento de que não havia um caminho "certo" a ser tomado e que, portanto, qualquer caminho seria válido. Tal lucidez mantém-se assegurada não somente pela riqueza e profundidade dos detalhes rememorados, mas antes pela questão: que importa se tomei este ou aquele caminho? É como se Nemo Nobody dissesse: cada "escolha impossível" me permite compreender a mim mesmo, não porque ela diz quem eu fui a partir da decisão que eu tomei, mas porque dialoga com quem eu sou atualmente, interferindo em minha interpretação do mundo ao propor-se sempre de maneira diferente. Negação seria, por exemplo, se houvesse um caminho ideal em que tudo daria certo.

Ocorre que, no entanto, cada versão da história interfere nas demais. Esse detalhe aparentemente fantasioso nada mais é do que afirmação da "escolha impossível" não mais como uma não-escolha (negação sistemática de qualquer outra escolha possível), e sim como uma escolha que traz em si um pouco de todas as demais possíveis. Trata-se da dinâmica simbólica que constitui a ficção: não podemos compreender o todo sem compreender suas partes e vice-versa; cada versão da história remete, por analogia, a uma história total, mais ampla, não redutível a memórias e 
escolhas pontuais. Daí que a articulação simbólica consiste num procedimento que não privilegia uma suposta "verdade" da história e tampouco a anula, mas permanece reescrevendo-a.

O plano da composição do filme é fundamental para a compreensão dessa dinâmica ficcional: as reflexões do Nemo criança justificam-se nas reflexões do Nemo adulto e nas do Nemo idoso, não havendo no fluxo narrativo um momento anterior nem posterior, apenas um movimento pendular (metaforizado na técnica de hipnose utilizada no filme pelo psiquiatra) que coloca sob suspeita qualquer veredicto definitivo. Interessante é que somos induzidos, em cada cena - sobretudo naquelas em que Nemo atua como apresentador de TV, falando sobre o universo e a física quântica - , a tentar reconhecer alguma ordem, finalidade ou causa que possa juntar, de modo coerente, todos os "cacos" de sentido espalhados pela memória de Nemo.

Entretanto, o fim do filme é contundente: não há princípio algum, nenhuma razão ou vontade ordenadora; não há sequer escolhas a serem feitas exceto aquela de aceitar e afirmar o eterno retorno dos mesmos impasses. "[...] se todas as possibilidades na ordem e relação das forças já não estivessem esgotadas, não teria passado ainda nenhuma infinidade. Justamente porque isto tem de ser, não há mais nenhuma possibilidade nova e é necessário que tudo já tenha estado aí, inúmeras vezes" (Nietzsche, 1999, § 7). Não se trata, evidentemente, do retorno do mesmo, mas justamente da ausência do "mesmo": se algo difere, difere como repetição, pois o que se repete é a diferença - diferença que, nos termos de Deleuze, implica uma não identidade (o que remete ao título do filme, "senhor ninguém”).

Quando dizemos que o eterno retorno não é o retorno do Mesmo, do Semelhante ou do Igual, queremos dizer que ele não pressupõe qualquer identidade. Ao contrário, ele se diz de um mundo sem identidade, sem semelhança, sem igualdade. Ele se diz de um mundo cujo próprio fundo é a diferença e em que tudo repousa sobre disparidades, diferenças que se repercutem indefinidamente (Deleuze, 1988, p. 385).

Por isso que, quando questionado pelo jornalista sobre qual de seus depoimentos seria o "verdadeiro", Nemo responde que todos são verdadeiros, já que "todas as coisas poderiam ser qualquer outra coisa e continuariam sendo significativas" ("everything could've been anything else and it would have just as much meaning") - eis o que considero ser a principal chave de leitura do filme. 
Tal perspectiva retoma a visão sofística em oposição à platônica, que se constitui a partir do axioma da verdade. De tal forma que, "a rigor", esse tipo de filme enuncia-se como "absurdo", mas a questão é: de que lado estaria o absurdo? Numa história cujo sentido é plural ou num indivíduo que vê sua expectativa de sentido frustrada? Sendo que, para que haja absurdo, é preciso haver um sentido ausente; e sendo que tal indivíduo, por sua vez, refere-se mais ao espectador do filme do que a seu protagonista, que prefere continuar "na mente de uma criança" para manter por perto todos os sentidos possíveis. De um lado, trata-se de uma fábula, decerto, criada para satisfazer a necessidade humana de criar sentido para a existência. De outro, a falta de sentido aparece na trama não como indício de "absurdo" (expectativa frustrada), mas antes como indício da prevalência do acaso: a chuva que borra o telefone anotado no papel, a moeda que leva Nemo a ser assassinado por engano, o caminhão de gasolina que explode à sua frente etc. É o acaso que se repete, indiferente ao que quer que seja. Quando certos princípios, como o efeito borboleta ou a teoria das supercordas, são mencionados, nossa interpretação é atiçada por iscas de sentido que nunca dão conta de fixar e mapear as circunstâncias que se abrem ao acaso.

Mas da constatação da fatalidade do acaso - optar pela mortalidade num mundo de imortais implica aprovar a falta de razão ou finalidade da existência — segue-se para o riso de escárnio e de alegria como resposta à altura do acaso que torna possíveis as circunstâncias e ocorrências (como a de viver num mundo de imortais). Não há "fora" nem "dentro" da vida, conspiração ou revelação; todos os fatos e possibilidades se igualam e respondem a uma mesma condição: aparecerem e desaparecerem ao acaso, sendo interpretados apesar de não serem interpretáveis. Se qualquer lembrança de Nemo poderia ter qualquer significado, não é porque não aconteceu, mas porque nunca houve um significado que a tenha determinado.

Com efeito, não há uma versão definitiva do passado: inventamos e confundimos lembranças que são tão "nossas" quanto poderiam ser de qualquer pessoa. A identidade do "senhor ninguém", portanto, não consiste em saber quem ele já foi um dia e quem ele tornou-se hoje, mas tão somente em não fazer ideia de quem ele será amanhã ou nos próximos minutos, de como as coisas vão passar, para onde vão ou de que modo antes que elas comecem a acontecer. Donde "[o]s maiores acontecimentos — não são as nossas horas mais barulhentas, mas as mais silenciosas" (Nietzsche, 2011, p. 163).

A questão que fica em aberto, portanto, é se encontramo-nos, cada um de nós, entre aqueles que vivem a vida como protagonistas de suas pequenas histórias, 
verdadeiras ou falsas, ou entre aqueles para os quais não resta ficção alguma além das "grandes narrativas" (religião, nação, partido etc.), que já definem de antemão quem somos ou deveríamos ser, engolindo e silenciando qualquer outra possibilidade.

\subsubsection{Análise de Em busca do tempo perdido: a redescoberta do descontínuo}

Sabe-se que Proust teria escrito o primeiro e o último volumes de Em busca do tempo perdido - respectivamente No caminho de Swann e $O$ tempo redescoberto num mesmo período de tempo e só depois teria completado o enorme intervalo entre eles. A comparação feita, com frequência, à construção de uma "grande catedral" não se deve, pois, apenas ao uso exemplar das belles lettres na construção de vitrais narrativos cuidadosamente erigidos e detalhados. Trata-se de uma "catedral" como metáfora narrativa: entre o final escrito antecipadamente e aquilo que o autor estabelece como início, há uma espécie de futuro-anterior cuja articulação aparece simultaneamente, ainda que sempre de maneiras diferentes, em todo o enredo.

Inserida no período inaugural do chamado romance moderno, a obra de Proust se constitui num extenso relato das relações que o narrador, na primeira pessoa do singular, estabelece com sua própria história, conjugadas numa série de reflexões subjetivas e cambiantes que, por sua vez, instauram dois focos principais que orientam toda a história: o tempo perdido e o tempo redescoberto. A consciência da passagem do tempo é relatada por meio de uma suspensão da própria duração, de modo a compreender o movimento incessante de "tempo perdido" que nos constitui. Por conseguinte, entretanto, este mesmo esforço de observar vestígios acaba por revelar aspectos diferentes, portanto "redescobertos", daquele tempo considerado perdido.

Não obstante, já são bem difundidos os paralelos entre a narrativa proustiana e o pensamento filosófico de Bergson, em sua abordagem acerca da sucessão do tempo (Cf. Sahm, 2011). Contudo, o possível diálogo conceitual entre Proust e Bergson parece levantar mais suspeitas do que analogias incisivas, ao menos quando se coloca em jogo as premissas metafísicas deste último autor - quanto a isso, remeto-me à aprofundada análise feita por Paul Ricoeur (1995, p. 225-274) no segundo tomo de seu Tempo e narrativa. Nessa análise, Ricoeur argumenta que, de modo distinto da concepção bergsoniana de tempo (como pura alteridade de si mesmo), a narrativa proustiana alude a uma noção de tempo que, uma vez relatado, funciona como uma espécie de filtro 
imanente de possibilidades que não se deixam ver pela mera sucessão das coisas vistas.

Significa que, na obra proustiana, os episódios são trazidos de acordo com as associações que a imaginação estabelece entre as diversas experiências vividas em diferentes momentos, podendo-se alternar a todo instante a localização de tais experiências numa mesma (e pressuposta) sucessão temporal linear. Isso não implica, para o narrador, a inexistência de uma realidade objetiva, apenas a constatação de uma posição sempre móvel a partir da qual ele percebe "o mundo" onde se encontra.

Assim, visitar um mesmo lugar, rever uma mesma pessoa ou ouvir novamente uma mesma música serão sempre experiências singulares cujos aspectos nunca coincidem plenamente, por mais que a memória permita o reconhecimento. É como se pudéssemos acompanhar lentamente cada momento como uma "tela em branco" que recebe, ao longo das minuciosas descrições, as manchas de tinta que vão compor figura e fundo, primeiro e segundo plano - mas com um ponto de vista em permanente deslocamento, apreendendo parcelas sempre diferentes de uma mesma cena.

Não é o caso, entretanto, de uma representação espacial do tempo como pura entidade abstrata, na qual se inserem momentos vividos a partir de um "preenchimento" espacial. A própria geografia descrita é descontínua, com lugares desconectados entre si, como um mapa fragmentado feito de espaços recortados e realocados numa grande área vazia, ainda não preenchida. Sob um viés trágico, trata-se da impossibilidade de se conceber uma realidade como totalidade e permanência, sugerindo, em vez disso, uma espécie de fluxo descontínuo, desde sempre aberto e indeterminável. Nisso somos remetidos de imediato à noção de "instante" que Bachelard adotou contra a duração bergsoniana: em vez de pensar na duração, como pensava Bergson (2006), em termos de continuidade permanente (embora virtual), Bachelard (1988) postulava a existência de lacunas imanentes na duração. Em suma, a tese bachelardiana afirma que a temporalidade só é vivida numa pluralidade de durações que não têm nem o mesmo ritmo nem a mesma solidez de encadeamento, tampouco o mesmo poder de continuidade.

Claro que todo acontecimento vivido é finito, encerrado na esfera do passado. Mas o viver em si, bem como o acontecimento lembrado, é sem limites, porque interfere na compreensão de tudo o que veio antes e depois. Retomando os focos reflexivos da obra proustiana, a ideia de um "tempo perdido" refere-se à impossibilidade de qualquer experiência ser revivida tal e qual, dado que toda experiência se conjuga de maneira única, irrecuperável, jamais idêntica. Disso decorre uma "busca" (recherche) por um 
tempo que, embora nunca reencontrado, tem a capacidade de se reinserir no presente por meio de um novo ponto de vista, revelando assim aspectos antes não percebidos. Tal desconfiança que está presente desde o início do romance confirma-se no desfecho, onde vislumbramos a reconstrução, por parte do narrador, de seu passado através da escrita fragmentada da história que acabamos de ler.

[...] metáfora e reconhecimento explicitam a relação sobre a qual se edifica também a impressão redescoberta, a relação entre a vida e a literatura. [...] É essa a riqueza de sentido do tempo redescoberto, ou antes da operação de redescobrir o tempo perdido. [...] $\mathrm{Na}$ medida em que, de fato, a vida representa o lado do tempo perdido e a literatura o lado do extratemporal, tem-se o direito de dizer que o tempo redescoberto exprime a retomada do tempo perdido no extratemporal, como a impressão redescoberta exprime a da vida $n a$ obra de arte (Ricoeur, 1995, p. 253-254).

Neste ponto, ao falar da "relação entre vida e literatura", Ricoeur parece ampliar aquela problemática levantada em A metáfora viva: até que ponto podem as obras ser consideradas como uma extensão em larga medida dos problemas condensados na explicação de uma metáfora local? Agora, essa questão adquire novas dimensões: como posso ser capaz de pensar em algo "novo", que eu já não tenha pensado de outro modo? Existe experiência possível que já não tenha sido minimamente vivida? Seria legítimo dizer que a experiência é uma coisa e que o pensamento que a interpreta e a expressa é outra? Poderia uma expressão tornar diferente aquilo que ela quer expressar? Embora possa parecer um tanto inútil ocupar-se com um pensamento que não foi expresso - o pensamento expressa-se enquanto pensa -, nada garante que a recíproca seja verdadeira: o que se expressa não foi o necessariamente pensado.

A expressão, assim, se mostra uma condição, se não necessária, ao menos incontornável do pensamento. Se eu digo que vida significa vida, não é porque a palavra "vida" seja equivalente à "vida em si", mas porque esta, a vida em si, não se distingue da expressão que faço dela — o que também não a fixa num sentido único e universalmente válido, mas me permite, ao contrário, continuar referindo-me à vida para dizer coisas diferentes com uma mesma palavra. Com efeito, tautologia é ao mesmo tempo condição e consequência da metáfora. Porque não é o mundo que deve se adaptar ao sentido, mas o inverso. $\mathrm{O}$ mundo não delimita a linguagem, mas fora dele a linguagem não faz sentido, é muda, desaparece junto à lógica que a constitui. 
É por isso que, quando Nietzsche (2009) fala de "tornar-se o que se é", 57 não é que haja um sentido de ser dado de antemão, mas exatamente o contrário: a dificuldade de ser é a dificuldade de não ser outra coisa. O sentido de "sou o que sou" sempre está para ser inventado, como confirmação ficcional da singularidade que implica ser o que se é. Analogamente, "articulação simbólica" implica fazer-falar o que se quer compreender: pôr em evidência o que já está em evidência, dar sentido e expressividade ao (in)significante, ao que se abre ao acaso, à ocasião que não se pode mudar, retocar ou substituir e que nem por isso se deixa reduzir a um único sentido.

\begin{abstract}
Mas, para voltar a mim, pensava mais modestamente em meu livro, e seria inexato que me preocupavam os que o leriam, os meus leitores. Porque, como já demonstrei, não seriam meus leitores, mas leitores de si mesmos, não passando de uma espécie de vidro de aumento, como os que ofereciam a um freguês o dono da loja de instrumentos ópticos em Combray, o livro graças ao qual eu lhes forneceria meios de se lerem (Proust, 2004, p. 280).
\end{abstract}

É assim que a noção proustiana de "tempo redescoberto" pode nos servir para compreender a dinâmica da articulação simbólica: o que se redescobre é a nós mesmos em relação ao mundo, e não um "tempo perdido" que não se deixaria repetir nem se tentássemos mil vezes. E o mundo assim redescoberto não é senão o acaso que se repete, a expressão que se repete para dizer outra coisa, o pensamento que retorna como novo, a diferença que só nasce da repetição. Se o sentido de uma expressão é a maneira como ela se refere ao mundo, a perspectiva sempre relativa e fugaz do narrador de $\mathrm{Em}$ busca do tempo perdido diz mais respeito a uma nitidez em relação aos artifícios imaginários, por meio dos quais compreendemos a realidade, do que a uma confusa limitação do olhar que só enxerga imagens emaranhadas. Em suma, o protagonista proustiano parece adotar uma premissa nietzschiana segundo a qual o mundo, não importa quanto tentemos adequá-lo a uma ideia, permanece não fixável.

Por isso que a estratégia da ficção, de agir como se já soubéssemos do fim mas sabendo que saber do fim nunca será útil quando se tratar do fim mesmo - , não se confunde com a de uma conspiração, uma ilusão, uma paranoia. Podemos redescobrir em tudo que vivemos uma grande parcela não vivida, desconhecida, coisas que

\footnotetext{
57 Tal imperativo, cuja autoria é atribuída a Píndaro, poeta grego, é apropriada por Nietzsche em contraposição à máxima de Delfos, "conhece-te a ti mesmo" (que é também atribuída a Sócrates) — pois esta última pressupõe uma verdade subjacente ao "ti mesmo" que se conhece, anulando de antemão a possibilidade de "vir a ser", tão cara a Nietzsche.
} 
aconteceram como se não tivessem acontecido. Tempo redescoberto, ou articulação simbólica do tempo, é esta reversibilidade pelo retorno irreversível - não contra o tempo ou sem contar o tempo, mas contando ao tempo. A ficção imita a vida: o que aconteceu veio a ser da mesma forma que poderia não ter vindo.

\subsubsection{Análise de Sinédoque, Nova York: a morte como ficção da vida}

Ao contrário da crítica recorrente acerca de Sinédoque, Nova York (Charlie Kaufman, 2008), não penso que o filme trata da melancolia e da autonegação de um suicida obsessivo, num suposto drama sobre "sentir-se morto sem saber que já se está". Evidentemente também não trata, como um Clube da Luta (David Fincher, 1999), de uma "tomada de consciência" contra todas as ilusões - o que dá no mesmo: uma negação (redentora, neste caso) da banalidade da vida cotidiana. Sinédoque me pareceu tão sutil quanto contundente. Levou-me até uma porta e me mostrou o que há para se ver por ali: a objetividade da morte, isto é, fonte segura de significação da vida.

O que mostra a objetividade da morte? Que o tempo passa e não cessa de passar, que tudo que é vivo nasce e morre, seja planta, animal e homem, que essa condição de transformação não cessa nem se modifica (eterno retorno), ou seja, "nada existe de permanente, a não ser a mudança" (Heráclito), que não há finalidade nem razão para que exista o que existe, que tudo é acaso, que a existência é sempre singular, que o homem não é o resultado de um progresso evolutivo dotado de planejamento ou vontade, mas uma variedade da matéria viva ao lado de outras tantas, animadas e inanimadas. Enfim, a consciência dessa objetividade da morte nos conduz à tautologia da existência. Para dizer o que o real é, temos de dizer que o real é o real, assim como diríamos da pedra que é uma pedra e da própria morte que é morte (Almeida, 2015b, p. 147).

Por meio dessa objetividade tautológica da morte (a morte é a morte), uma questão permanece em aberto do começo ao fim do filme: estaríamos aptos a aprovar uma vida que surgiu por acaso e igualmente se destina a sumir? Ou seja, não é da morte que se trata o filme - ela é objetiva, incontornável —, e sim da maneira como, diante dela, torna-se possível dotar a vida de significados diversos. Não é de se espantar, com efeito, que Synecdoche tenha gerado uma miríade de sinopses diferentes - vejamos a 
“compilação" de algumas delas. Caden Cotard transforma sua própria vida numa ficção, tentando com isso torná-la mais real e, ao chocar-se nos limites de sua realidade particular, percebe que não existe uma única realidade possível, mas que cada ator/personagem constitui um mundo particular e, ao mesmo tempo, todos os mundos possíveis. Outra versão: diretor de teatro hipocondríaco elabora uma peça sobre si mesmo sob as lentes da Síndrome de Cotard - também conhecida como síndrome do cadáver ambulante, um delírio cujo principal sintoma é a ilusão de que se está morrendo ou de que os órgãos internos estão apodrecendo - , chegando ao estado crônico de não viver o presente à medida que o transforma numa peça imaginária. Versão mais difundida: após ser abandonado pela esposa e filha, diretor de teatro adoece e procura destilar sua dor por meio de uma peça metalinguística e megalomaníaca que, jamais apresentada ao público, torna-se abstrata e incompreensível.

Em Sinédoque, Charlie Kaufman não apenas "conta" a história de Caden Cotard, mas quer realizar a façanha de apresentar, em aproximadamente três horas, a vida inteira do protagonista. Não cabe aqui, portanto, enumerar todos os detalhes da trama, mas podemos começar com um "ponto de virada": Caden recebe um prêmio em dinheiro aparentemente ilimitado, com o qual ele aluga um gigantesco armazém em Manhattan onde passará anos construindo e reconstruindo o que seria sua opus magnum — uma peça de teatro hiper-realista que retrata perfeitamente a realidade em que ele vive e, por extensão, a existência humana como um todo. Tal pretensão explica a figura de linguagem contida no título do filme: "sinédoque" significa tomar a parte pelo todo e vice-versa, como uma experiência particular que traz em si uma experiência geral - o que também pode sugerir a imagem de Kaufman assumindo pela primeira vez a direção de seu roteiro, isto é, a de um artista tentando controlar sua própria obra.

Pulemos para o fim do filme: já idoso, Caden vive seus últimos anos no apartamento cenográfico de Adele, sua ex-esposa, agora não mais como diretor da peça, mas fazendo o papel de Ellen (a faxineira de sua ex-esposa) e cumprindo passivamente as instruções da nova diretora da peça (a atriz que antes interpretava Ellen). Aos poucos, as memórias de Caden se misturam com as da personagem que ele interpreta. Quando Caden finalmente sai do apartamento, após anos de reclusão, depara-se com o armazém em ruínas. Caminhando por ele, a voz da diretora lhe conduz para o fim: 
deslizando silenciosamente para fora dela. Esta é a experiência de cada um. Os detalhes não importam. Cada um é cada um. Assim, você é Adele, Hazel, Claire, Olive. Você é Ellen. Toda a miserável tristeza dela é sua. Toda a solidão dela. O cabelo cinza como palha. As mãos dela, feridas e vermelhas. São suas. Como as pessoas que amam você e param de amá-lo, como se morressem, como se seguissem em frente, como se você as apagasse, como lhe apagaram sua beleza, sua juventude. Como se o mundo esquecesse você, como se você reconhecesse sua transitoriedade, como se você começasse a perder suas características, uma por uma.

Esta última cena se encerra no mesmo horário, 7h44, em que se inicia a primeira cena do filme. Eis uma curiosa senha do roteiro: entre uma cena e outra, sempre se passa muito tempo, algo como piscar os olhos entre um dia e outro, um ano e outro, uma década e uma vida inteira; mas também é como se o tempo não passasse nunca. Se, por um lado, esse recurso parece evocar uma ode metalinguística do cinema enquanto fluxo temporal que, para fluir, não se deixa notar - por outro, também parece sinalizar certa dificuldade do protagonista em assimilar o tempo que passa.

No início do filme, estamos em setembro, mas logo quando Caden sai para conferir a caixa de correio vemos que já é outubro. Retorna para dentro de casa, abre a geladeira e, ao verificar que a validade do leite está vencida, percebemos que mais alguns dias se passaram. Caden volta sua atenção ao jornal, abre na página dos obituários, e já estamos em novembro. Passa-se para a próxima cena, Caden repete o gesto e vemos que o jornal já é de maio do ano seguinte. Assim, as cenas do filme são construídas: sem aviso prévio, os fatos não ocorrem sucessivamente, mas se "atropelam". A ordem das cenas, os diálogos e seus respectivos significados, portanto, apresentam-se de acordo com a forma como foram vivenciados por Caden.

Apressado seria com isso deduzir - por mais que aparentemente esta seja uma interpretação recorrente - que o protagonista, por não notar a duração "normal" das coisas, quer a todo custo antecipar sua própria morte. Se o tempo passa despercebido para Caden, é menos por conta de uma lamentação romântica acerca da fugacidade do tempo e mais por uma atitude "perfeccionista" em querer apreender o tempo vivido. Tal atitude aproxima-se da tríade "do olhar do geógrafo, do espírito do viajante e da criação do romancista" de que fala Paul Ricoeur (1994, p. 309) no tomo I de seu Tempo e narrativa: do olhar do geógrafo que não deixa escapar nenhum detalhe, somado ao espírito do viajante que vai ao encontro do que lhe parece estranho, emerge a criação do 
romancista que, com o apuro das palavras, reorganiza a estranheza de sua experiência para que um leitor em potencial possa vivenciar, à sua maneira, o encontro com o estranho-. Explicitemos tal analogia.

No plano da linguagem visual de Sinédoque, o primeiro aspecto notável é a predominância da cor verde. As roupas, paredes, o nome Oliva (filha de Caden). Verde que remete a floresta, a selva, a pantanal, como se o mundo percebido por Caden fosse sempre um lugar desconhecido e ameaçador: coisas e pessoas simplesmente aparecem e desaparecem a todo instante, de modo que, no decorrer das cenas, muitos detalhes nos escapam, assim como também escapam a Caden. A isso devemos acrescentar o fato de que, enquanto Adele, sua ex-esposa, articula o mundo numa escala extremamente pequena (ela se torna famosa por suas pinturas hiper-realistas em miniatura), Caden tenta fazer o mesmo com escalas incrivelmente grandes: literalmente uma "réplica" em tamanho real de Nova Iorque. Uma sinédoque assim operada procura o máximo de literalidade: em determinado dia de ensaio, e na tentativa de reproduzir um diálogo que foi ouvido por "detrás da parede", Caden decide cobrir a cena com um muro, tornando-a mais imprecisa e, ao mesmo tempo, mais fidedigna.

Com tal acuidade dramatúrgica, Caden lança mão de seu "espírito viajante" de estranhar o mundo e, à maneira do "geógrafo" que não deixa escapar nenhum detalhe, tenta compor um romance que possa reorganizar aquilo que lhe parecia estranho. E quanto à sua dificuldade de assimilar o tempo que passa? Quando Caden perde seu cargo de diretor, a nova diretora descreve o protagonista de sua peça como um homem que "vive num mundo pela metade, entre o imobilismo e anti-imobilismo, e o tempo é concentrado numa cronologia confusa [...] para sua situação fazer sentido", concluindo que ele já está morto. Porém, em seguida, o assistente dela discorda: "Eu não vejo isso de forma alguma. Eu vejo muito mais do que isso, vejo algo de vivacidade." Não apenas saliento esse ponto de vista, como também quero aplicá-lo ao filme como um todo: talvez aquilo que em Sinédoque pareça ser algum delírio que nega a realidade temporal seja, pelo contrário, a expressão de um olhar obcecado em afirmar sua realidade retratando-a literalmente como ele a percebe.

Ao articular suas experiências desconsiderando o desenrolar "normal" do tempo, Caden quer reconhecer não apenas o aspecto fragmentado da temporalidade, mas também o próprio mundo recebendo o "verde" desse olhar que assim o enxerga. Logo, sua dificuldade perante o tempo talvez seja, ao contrário do que apressadamente se possa supor, uma manobra plenamente eficaz em atualizar, no sentido de reorganizar, 
redescobrir e fazer aparecer, sua própria situação no mundo. Manobra um tanto excêntrica, decerto, mas que apenas se detém na constante "falha" de um fluxo temporal que "deveria" ser contínuo e linear, mas nunca é - falha esta, aliás, que alguns apontam na "continuidade" da edição do filme. Deste modo, somos levados a questionar, com Caden, por que queremos ver tal cadeia ininterrupta.

Ricoeur (1994) argumenta que o desenrolar do tempo sempre se produz no terreno do imaginário, onde toda descontinuidade tende a ser transfigurada em narrativa (continuidade). No entanto, assim como é preciso esquecer para que a memória lembre, e é preciso lembrar para saber que esquecemos (um só existe com o outro), a continuidade temporal que reconhecemos e esperamos ver no mundo somente existe em contrapartida à descontinuidade, ao acaso e à finitude que se interpõem em nossa relação com o mundo - pois, em última instância, são inerentes à nossa existência nele. A obsessão de Caden parece repousar nesta contrapartida necessária à continuidade, como um curto-circuito entre o desejo de permanência e a consciência do fim.

No decorrer do filme, entretanto, tais polos não deixam de ser conciliados. De acordo com Durand (1997), esse processo de conciliação temporal-existencial pode guinar seguindo três estratégias elementares: a heroica (de combate), a mística (de inversão) e a dramática (de reconciliação) — estando as três modalidades presentes em Sinédoque. A primeira delas é evidente no próprio projeto de Caden, por onde ele tentará dominar sua angústia no embate com suas "sombras" — que são todos os atores por ele elencados, mas especialmente a figura de Sammy, que gera o encontro paradigmático do "torna-te quem tu és". A estratégia "mística", por sua vez, aparece quando Caden, ao deixar de ser o diretor de sua peça, inverte sua vontade de controlar e, no repouso da noite, sente prazer em servir, invisível e silenciosamente. Por fim, a estratégia "dramática" ocorre quando Hazel (assistente apaixonada por Caden), pouco antes de morrer asfixiada com a fumaça de sua casa em chamas, enuncia que seu fim foi escolhido no começo (ao decidir morar numa casa que está desde sempre em chamas) - sinédoque para cada escolha que ressoa ao longo de nossas vidas.

Se o tempo continua passando despercebido, é porque, em suma, Caden só se atém ao presente. E isso a partir de uma manobra peculiar de articulação simbólica, a saber, pela sinédoque que engendra uma objetivação da experiência subjetiva em forma de "mundo-do-texto", pelo qual se repercutem outros mundos particulares. Sem a articulação simbólica diante do mundo, com efeito, nossas experiências permanecem mergulhadas na especulação silenciosa e imprecisa da subjetividade. No caso de Caden, 
a réplica do mundo num armazém cenográfico não resulta apenas de um olhar subjetivo que o impede de perceber o tempo passar; é, na verdade, uma maneira de objetivar o tempo pelo olhar e no espaço (do palco), o que ilustra precisamente a tese de Ricoeur (2011, p. 34) de que o tempo narrativo cria o espaço:

[...] pensemos somente na desproporção entre o breve tempo dos mortais e o grande tempo dos movimentos siderais. Mas a desproporção não é apenas quantitativa, mas qualitativa, entre um tempo com presente, futuro, passado - em outras palavras, um tempo estruturado pela atenção, pela antecipação, pela memória - e um tempo sem presente, constituído por uma sequência infinita de instantes que não passam de cortes virtuais na continuidade da mudança. Essa aporética do tempo, como a denomino, constitui a meu ver a transição mais importante da configuração interna da narrativa para a refiguração do espaço pela narrativa. Não que a narrativa à medida que se desenvolve resolva os paradoxos do tempo. Pelo menos os torna produtivos.

O tempo torna-se "produtivo", como pontua Ricoeur, porque o distanciamento implicado na objetivação do mundo paradoxalmente obtém êxito em vencer uma distância, aquela de uma situação vivida como alheia, estranha ou apenas "despercebida" e que assim pode ser reaproximada, isto é, transposta a um espaço de que se possa apropriar. Neste ínterim, o tempo presente vivido por Caden não é negado, mas constantemente deslocado de um nível subjetivo para um horizonte mais amplo, aquele das diferentes maneiras de ser-no-mundo. Desse modo, a articulação simbólica da sinédoque procede como "reprodução produtora" de modos-de-ser.

Afinal, se é verdade que a ficção cria um mundo, é antes (e depois) para servir ao engajamento, à reaproximação, ao retorno do mundo mesmo, o único que existe, que assim é redescoberto à medida que cada indivíduo descobre a si mesmo inserido nele. Se até aqui insisti em elucidar esta manobra hermenêutica de reprodução como redescoberta, redescrição e mesmo reinserção, foi para sublinhar que não vejo na obra de Caden um movimento de fuga ou negação da realidade. A execução de uma obra sobre o viver-para-morrer, não podendo ser experimentada senão como ficção, adquire sentido e referência somente se contrastada à vida, neste caso como uma reprodução literal que torna precioso cada minuto, como "parte" maior que o "todo". Assim, longe de ter pleno domínio sobre sua situação de ser-no-mundo para partir dela como a priori de sua compreensão das coisas (também conhecido como "preconceito"), Caden prefere 
afirmar a realidade tão somente pela transitoriedade de todas as situações.

No decorrer de todo o filme, vemos em Caden, de fato, uma angústia constante, mas que por vezes se confunde com uma expressão de "espanto" ou de curiosidade. Fazer tal distinção pode indicar nesse personagem um modo peculiar de protagonismo. Quando os heróis da epopeia arcaica venciam, ou quando eram vencidos, conservavam sua "grandeza" até o último suspiro. Já os personagens romanescos, a exemplo de Dom Quixote, não pedem para serem admirados por suas virtudes; pelo contrário, querem que os assimilemos em sua trivialidade. O que há para se ver em personagens "sem qualidades" não são motivos pelos quais tiveram de colocar sua vida em risco, mas as pequenas escolhas, perdas, conquistas, desistências. É neste registro que, em Sinédoque, deparamo-nos com uma espécie de "virtude do perdedor", de quem é capaz de abandonar algo, seja um ideal que se almeja alcançar, seja o próprio trauma de não o ter alcançado. Em que medida esse abandono é virtuoso? Na medida em que enxerga beleza, ainda que por um instante, mesmo que por acidente, num mundo que é mais afeito às baratas do que aos humanos.

O triângulo entre Caden, Claire e Hazel expressa com precisão esse tipo de "virtude". De um lado, Caden tenta substituir seu primeiro casamento, fracassado, casando-se com Claire, que interpreta sua primeira esposa, repetindo com ela o mesmo fracasso de antes. De outro, Hazel, assistente apaixonada por Caden, debruça-se em remorso mediante a indiferença do diretor na primeira oportunidade que teve de levá-lo para cama. Porém, o único momento do filme em que Caden demonstra alegria, ainda que por um instante, é quando ele finalmente faz sexo com Hazel, pouco antes de ela morrer asfixiada com a fumaça de sua casa. No decorrer das décadas que nos levam a este ponto, vários "ideais de vida" tiveram de ser abandonados por Caden.

Não é que o protagonista tenha meramente se "resignado" com o que lhe restou; pelo contrário, ele apenas redescobre, aos poucos, um presente que sempre esteve ali, presente. É interessante, quanto a isso, contrapor o nome do protagonista ao nome de sua primeira esposa: "Adele" é um virundum (homofonia) para "a delicate art", ao passo que Caden Cotard parece sugerir "decadent art". Enquanto ele procura compreender a vida em sua decadência (finitude, fatalidade, deterioração), Adele parece preferir "retocar" o mundo reproduzindo-o em miniatura — vale dizer, selecionando apenas os traços que lhe convêm. Isso fica evidente logo no início do filme, quando Caden fala de vasos sanguíneos para explicar o que são "canos" para sua filha, que fica nervosa porque não queria ter sangue no corpo - então Adele censura o marido e acalma a 
criança, dizendo-lhe "não se preocupe querida, você não tem sangue".

Ademais, há uma cena em que Caden vai ao prédio onde Adele fica hospedada em Nova York e aperta o interfone no qual lemos, abaixo do número do apartamento dela, a palavra "capgras". Síndrome de Capgras designa um transtorno psiquiátrico caracterizado pela ilusão de que algum conhecido, normalmente um cônjuge, foi substituído por um impostor idêntico a ele. Esta referência explica a antiga fantasia de Adele de imaginar seu marido morrendo, sintoma de um delírio iminente de que a pessoa com quem ela se casou teria sido trocada por um desconhecido. Por conseguinte, vemos esse transtorno ecoando no trabalho de Caden, onde pessoas são substituídas por atores o tempo todo e, ao final, ele próprio substitui e é substituído por uma atriz secundária, que passa a dirigir a peça e lhe dar instruções pelo fone de ouvido.

Quer dizer, ao contrário de Adele (que sofre com tal ilusão até o fim de sua vida), Caden sabe e insiste no fato de que tudo isso que vemos, tudo isso que tem algum significado, que nos faz ter medo, que nos motiva a ser pessoas melhores, que nos dá a ilusão de caminhar para algum lugar... tudo isso é representação. $O$ fim de sua peça (que também fracassa) apenas salienta o fato de que não há nada de "nobre" em nossa existência, uma vez que somos seres finitos, em constante deterioração e muitas vezes invisíveis uns aos outros - o que não nos impede, e este é o ponto, de também sermos sensíveis, inventivos, amorosos e, enfim, importantes uns aos outros.

Numa entrevista, Kaufman fez questão de explicitar esta questão: “enquanto Caden acredita que está morrendo ao longo do filme inteiro, ele é, de fato, a última pessoa que se preocupa em morrer." ${ }^{58}$ Com efeito, não faz sentido dizer que Caden, além de angustiado, é suicida: embora não acredite que as coisas possam melhorar, também não acredita que as coisas possam piorar, pois para isso deveria haver algum momento em que as coisas já foram melhores. Ao contrário de um suicida, pois, que entre o nada e uma vida de sofrimentos opta pelo nada, ele se mantém diante de uma porta entreaberta sem nunca ultrapassá-la, pois sabe que não há nada atrás dela.

Para Caden, portanto, entre o prazer e o sofrimento não há escolha, somente o acaso dos encontros e a redundância das representações — somente espetáculo, aparência, sensações. A única escolha possível, a da aprovação ou recusa da vida, será por ele tomada aos poucos. A princípio, ele se angustia com o movimento ininterrupto

\footnotetext{
58 " [...] while Caden believes he is dying throughout the film, he is in fact the last of the people he cares about to die". Cf. WGA West, Charlie Kaufman on his latest film and why "movies are dead". Vídeo publicado em 23 out. 2008. Disponível em: http://youtu.be/oxps3oouNiQ. Acesso em 11 jul. 2015.
} 
da vida e, sobretudo, com sua incapacidade de apreender tal movimento: ele não sente as coisas durarem ou desaparecerem e espanta-se com as mudanças que de repente lhe ocorrem. Desconfia delas, mas não as nega. Com o tempo, porém, diante da impossibilidade de um real sem representação, Caden afirmará a vida num ensaio sobre a morte que jamais deixará de ser apenas isso, um ensaio - esboço análogo ao que descreve Milan Kundera (1985, p. 14) no início de sua A insustentável leveza do ser:

\footnotetext{
Não existe meio de verificar qual é a boa decisão, pois não existe termo de comparação. Tudo é vivido pela primeira vez e sem preparação. Como se um ator entrasse em cena sem nunca ter ensaiado. Mas o que pode valer a vida, se o primeiro ensaio da vida já é a própria vida? É isso que faz com que a vida pareça sempre um esboço. No entanto, mesmo "esboço" não é a palavra certa porque um esboço é sempre um projeto de alguma coisa, a preparação de um quadro, ao passo que o esboço que é a nossa vida não é o esboço de nada, é um esboço sem quadro. Tomas repete para si mesmo o provérbio alemão: einmal ist keinmal, uma vez não conta, uma vez é nunca. Não poder viver uma vida é como não viver nunca.
}

Acrescentemos: não porque a vida seja pouco perante a ideia que se faz dela, mas, o contrário, porque ideia alguma é suficiente para substituir ou aprimorar uma vida na qual cada existência particular reflete e é refletida por todas as outras.

Caso esse filme ainda soe "pessimista" para alguns, proponho, a título de exercício e para defender meu ponto, imaginarmos um final ligeiramente diferente: Caden abre os olhos na penumbra do apartamento de Adele e volta a exalar um odor insuportável que, logo se dá conta, é de sua própria urina acumulada na cama. A diretora costuma mandar alguém para limpá-lo, mas hoje parece ter esquecido. E Caden sabe que, assim que a diretora lembrar, ela o humilhará com todo tipo de injúria - "por que você não morre logo antes de se borrar todo de novo?’. Caden não pode fazer nada, nem mesmo suicidar-se. Nunca a morte lhe pareceu tão difícil. Não lhe resta outra opção além de continuar deitado, imerso naquele colchão azedo, aflito com os jovens que uma hora ou outra aparecem para culpá-lo de sua condição indigesta, dia após dia.

Perdoem-me a hipérbole de mau gosto, mas acredito que esta sim é uma angústia muito comum, embora amplamente ignorada, de todos aqueles que se encontram, como Caden, abandonados por seus entes queridos. Quer dizer, se já não soubéssemos o que significa envelhecer num mundo em que o idoso é um ser invisível, num mundo que 
endeusa o futuro (os mais jovens) e onde todos temem a vergonha de não desaparecer após atingir um "prazo de validade", neste caso Caden talvez desistisse de viver.

Mas este não é o caso de Sinédoque. Acho importante frisar que a angústia de Caden não é tanto por ele mesmo, e sim por constatar que cada pessoa ao seu redor não escapa, ainda que por um instante, de angustiar-se. Com o quê? Cada qual com seus demônios, a princípio, mas em todo caso com o invariável fato de que cada existência, em sua delicadeza e intensidade, sumirá sem sequer ser notada. Caden espanta-se com a previsível carência alheia, essa necessidade do indivíduo em ser reconhecido, compreendido e aceito, sua vulnerabilidade ao mínimo gesto solidário, essa inclinação tão simples e tão arriscada à compaixão e à empatia pelo próximo.

O espanto de Caden, sobretudo diante do potencial de cada pessoa em refletir todas as outras, manifesta-se como angústia que expressa, em última análise, uma hipersensibilidade à fragilidade individual - mais às dos outros do que à de si mesmo. É possível que tal suscetibilidade tenha sido aguçada paradoxalmente a partir de sua incapacidade de chorar e salivar (explicitada desde o início do filme), o que de algum modo também indica certa inaptidão de expressar a dor que sente.

Não há como não recordar aqui, por fim, os dizeres de Fernando Pessoa acerca do poeta que emula a dor alheia a partir de sua própria dor. Reciprocamente, nós que vemos a peça de Caden enquanto ela é construída, não sentimos a dor dele nem a dos demais personagens, tampouco a nossa ou a de Kaufman, mas sentimos uma dor nova, aquela que é criada diante do filme e que só pode ser compreendida pela experiência individual de cada espectador em relação à sua própria dor. 


\section{INTERLÚDIO IV: Daquilo que, quando você}

\section{para de acreditar, não desaparece}

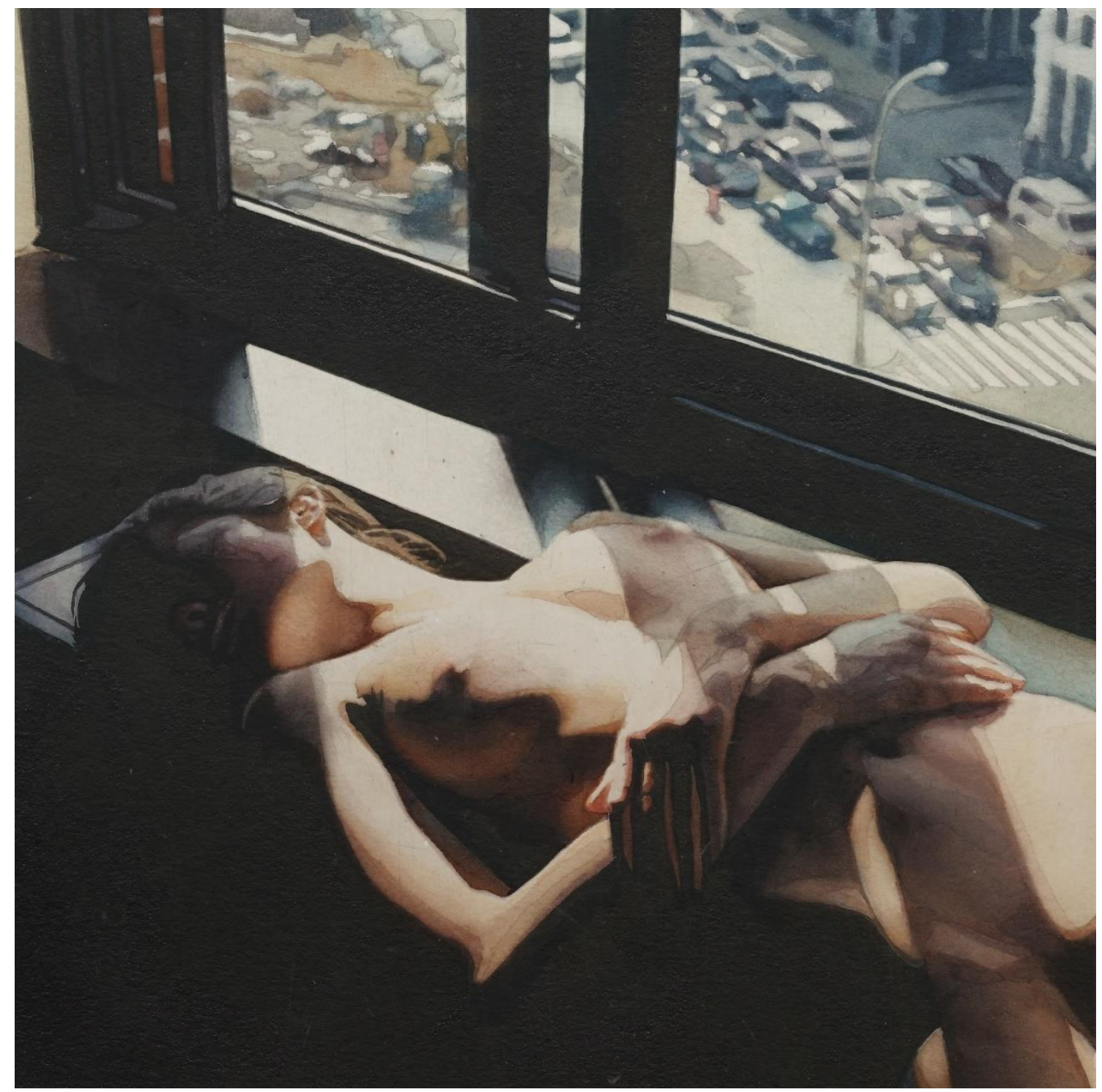

Para o nosso olho é mais cômodo, em uma dada ocasião, reproduzir uma imagem já produzida com frequência do que fixar o que há de novo e diferente em uma impressão.

— Nietzsche, Além do bem e do mal, V, § 192.

Não sei desenhar. Em casa ou num atelier eu até consigo: o espaço delimitado, a previsão fácil da luz, o enquadramento ali ao alcance do olhar. Mas se estou na rua, aí complica tudo. Minha vista escurece, nada fica parado e, quando menos se espera, aquelas luzes se transformam em sombras. Sensação de vertigem, meu traço é impotente em meio a um oceano de cores. Daí que quando alguém vem com uma pergunta do tipo 
“você desenha?", eu digo que não.

E pensar que, adolescente, eu desenhava numa feira a céu aberto... na patética ideia de ganhar uns trocados desenhando as pessoas no meio do vai e vem em que todos se esbarram. Pior, algumas vezes fui assaltado no final do expediente. Meu corpo virava um caldo grosso, meus olhos ferviam por dentro. Nunca desafogava, preferia destilar a raiva gota a gota, como um ninja em posição fetal. Como eu disse, ridículo.

A verdade é que eu queria crescer o quanto antes. Na escola, aquela professora sorridente dizia que a Terra é redonda, mas a gravidade permite que o homem não caia. Eu levantava, tropeçava e caía na frente dela; ninguém achava graça. É a supremacia da gravidade: minha arrogância rendeu-me as surras dos garotos mais fortes. Vinganças abstratas não aliviavam a dor, mesmo assim eu tentava resolver na ponta do lápis. Pedacinhos da professora voando em direção centrífuga, a partir do ventilador.

Mas também desenhava as meninas, dando-me conta que elas sorriam com isso. Rabiscava rapidamente o caderno porque o sinal do recreio nunca esperava. Assim era fácil desenhar. Meus pulmões enchiam e o traço saía logo. Ninguém me avisou que, no dia seguinte, eu seria ignorado novamente. Puro desdém. De fato, o belo é algo de muito efêmero, instável, precário - ele anuncia o próprio fim. Este é o trabalho, esta a fadiga: falar ou calar, tentar ou renunciar no momento oportuno.

Por isso desenhar sempre me pareceu algo clandestino, que não serve para absolutamente nada exceto roubar um sorriso. O refinamento consiste na manutenção dos gestos, porque as situações nunca são iguais. É como a lenda de Dédalo e Ícaro: o pai aconselha o filho a não voar muito alto, porque o sol derreteria as asas de cera, nem muito baixo, porque a água do mar ensoparia as penas, mas sim entre um e outro, no entremeio. Gosto de pensar nisso ao ensinar meus alunos.

Sim, não escapei, virei professor de desenho. O bom é que não preciso mais desenhar a céu aberto. Seria como nadar em alto mar após um trauma de naufrágio. Prefiro nadar na piscina, onde meus pés tocam o chão. No mar, não há a segurança das bordas da piscina. O perigo de nadar em alto mar, sei bem, é a possibilidade da cãibra. A rigidez dos músculos. $\mathrm{O}$ traço que não sai.

Entretanto, não posso ensinar o manual básico de desafogamento o mais distante possível da água. Porque nos olhos de cada aluno há o temor perante um vasto oceano cercado de horizontes por todos os lados. Quer dizer, fora da sala de aula, tentar usar os métodos do nado em piscina é completamente inútil. $\mathrm{O}$ mar exige outra sabedoria: aprender a boiar. Coisa perigosa de se fazer em piscinas: corre-se o risco de bater a 
cabeça nas bordas, um perigo que antes servia de proteção.

Essa coisa de boiar é meio epicurista: àquilo que desagrada, habitue-se; aos poucos não lhe dará mais importância. Aquilo que assim foi não o é mais. Não se trata de ficar comendo alface e melancia para ficar leve e poder boiar. A questão filosófica aqui é: esquecer que se está boiando. É sim! Não há como boiar se você pensar no abismo abaixo. É preciso certo consentimento, um entregar-se sem reservas. Suspender e fazer calar os medos, os anseios, as técnicas e os saberes que pretendem impor-se rumorosamente contra o mundano, o superficial.

Sensação estranha esta, tudo fica mais leve. Fazer-se notar sendo discreto, flutuar na superfície, atentando ao momento oportuno. Para tanto, também é preciso esquecer o oceano - nunca saímos de nossas pequenas piscinas, porque na superfície todas as piscinas já estão juntas, são inseparáveis do presente, da própria situação, daquilo que nos é oferecido. Isto é design, não mais desenho. O mar só existe como ressentimento, como fantasma individual. Aprender a nadar é uma forma de não se afogar, mas aprender a boiar é a assimilação total do nado: capacidade de movimentarse lentamente, conforme cada ocasião.

Claro que é fácil falar isso tendo uma praia firme ao alcance da vista. Mas olho para trás e vejo o quanto eu acordava confiante, com um olhar desimpedido, quando meus dias se resumiam a um sorriso de uma menina da escola. Quando eu imaginava alegrias e decepções que nunca terminariam. Quando as coisas ficavam mais leves. De certo modo, eu já estava boiando, para não perder de vista o grande céu. 


\section{DESIGN COMO ARTICULAÇÃO SIMBÓLICA}

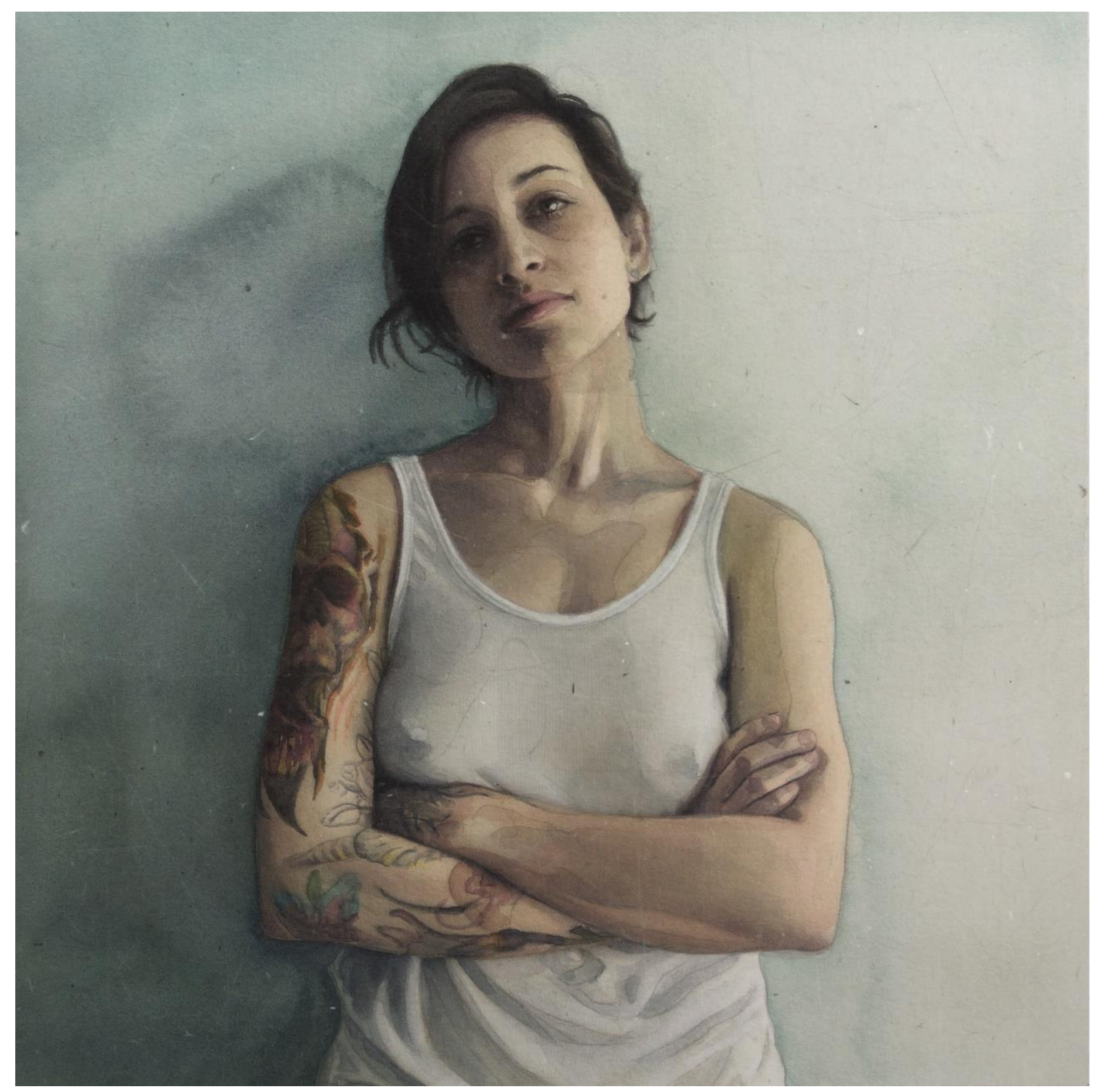

Queremos ver a nós mesmos traduzidos em pedra e planta, queremos passear em nós mesmos, ao andar por essas galerias e jardins.

— Nietzsche, Gaia Ciência, § 280.

Uma vez delineado o que se pode denominar "fundamentação teórica" - meus pontos de partida, influências e posicionamentos —, pretendo agora propor a tese segundo a qual o design funciona como "articulação simbólica" na lida estética das pessoas consigo mesmas e com o mundo. Para tanto, é necessário retomar o mais brevemente possível algumas premissas pontuais e, não obstante, introduzir um sucinto panorama do design enquanto campo profissional e do conhecimento. A este panorama, ademais, contraponho, no tópico 4.1, certa genealogia do design a partir da arte 
helenística para desvelar a relação intrínseca entre tais conceitos, arte e design relação esta que costuma ser polemizada no design e que, no entanto, é fundamental à caracterização de uma articulação simbólica. Por fim, descrevo no tópico 4.2 o design como articulação simbólica da experiência estética por ele articulada.

Vimos que, uma vez constatada a existência em sua casualidade (como fruto do acaso), todo o resto não passa de expressões, representações, mediações, relações com o mundo. Por isso cheguei a antecipar, no capítulo 1, que todas as construções, científicas, filosóficas ou mesmo religiosas, guardam uma aproximação maior do que se supõe com o design: mediações perante as quais somos capazes de redescrever o mundo, para compreendermo-nos em relação a ele. Destarte as ficções mediadas pelo design podem ser compreendidas como enunciados simbólicos que, ao serem interpretados, refletem e proporcionam "modos de ser" diversos.

Não é difícil notar, assim, que o enunciado de que o "design funciona como articulação simbólica" está desde o início implicado em meus argumentos: está claro que articulação simbólica perpassa a literatura, a ciência, o cinema e, enfim, toda a miríade de expressões culturais. A proposição que resta a ser feita, portanto, concerne precisamente ao modo particular pelo qual o design desempenha esse processo. Modo este que, no entanto, só pode fazer sentido caso encaremos o design como uma forma de pensamento, de conhecimento e de ação análoga à forma filosófica, literária, artística, isto é, como tradução de traduções, como constante processo de mediação e (re)criação de significados. Sob a perspectiva de uma "hermenêutica trágica", conforme a conceituei, essa relação torna-se mais clara: a criatividade do designer (assim como a do cineasta, do filósofo, do cientista etc.) repagina, remoldura, reveste, dá novas formas às coisas e eventos que a todo instante traduzimos em conceitos.

Mesmo a atividade do projeto, pela qual se convencionou nomear de "design", não deixa de ser uma espécie de tradução; uma tradução restrita, ou seja, ordenada e direcionada a algum propósito preestabelecido. Encarar o design como articulação simbólica, porém, implica não restringir o design à atividade do projeto - afinal, do mesmo modo como ocorre nas superstições, nas teorias filosóficas e na ciência, não há propósito, lei ou necessidade que não tenham sido imaginados pelo homem, isto é, que não passem pelas imagens, expressões e mediações que estabelecemos com o mundo e conosco mesmos. Sendo assim, a pertinência da ideia de articulação simbólica reside em tornar visível este processo ficcional que se abre, queira ou não, também por meio do design. Em outras palavras, uma vez que objetos e imagens nos sugerem condutas, 
"estilos de vida", valores e significados, é pertinente a uma filosofia do design investigar e dimensionar o imaginário contemporâneo do design.

"Dimensionar" implica, no sentido nietzschiano, uma empreitada genealógica: identificar recorrências discursivas que nos permitam elaborar hipóteses filosóficas, neste caso, sobre o funcionamento do design. Deste modo, mais importante do que, por exemplo, a história - enquanto pressuposta "verdade dos fatos" — é a maneira como a contamos, ou seja, o design das histórias. Ou ainda, nos termos do historiador Philip B. Meggs (2009, p. 10), em sua História do design gráfico:

O caráter efêmero e imediato do design gráfico, combinado com sua ligação com a vida social, política e econômica de uma determinada cultura, permite que ele expresse mais intimamente o Zeitgeist [paradigma] de uma época do que muitas outras formas de expressão humana. Ivan Chermayeff, renomado designer, disse: o design da história é a história do design.

É preciso sublinhar que a história contada por Meggs é a do design gráfico, e não a do design em geral - o que logo de início nos impõe uma disparidade conceitual. Enquanto o termo "design industrial" só começa a designar uma atividade profissional em meados do século XX, nomeadamente como Gestaltung (“dar forma" em alemão), a atividade do "design gráfico", como sustenta Meggs, é herdeira de uma ancestralidade mais ampla: desde os escribas sumérios que inventaram a escrita, os artesãos egípcios que combinaram palavras e imagens sobre os papiros, os impressores chineses de blocos de madeira, passando pelos iluminadores medievais e os tipógrafos do século XV, que conceberam os primeiros livros europeus impressos, e chegando finalmente à eclosão dos softwares gráficos que atualmente são imprescindíveis ao design.

Não significa que design gráfico seja uma atividade distinta do design; a questão é que há, para o design, uma miríade de versões históricas distintas — de modo geral, trata-se de admitir ou não que o design tenha sua origem na Revolução Industrial. No caso de Meggs (idem), vemos claramente uma recusa - com a qual compactuo - a essa restrição histórica do design:

Desde os tempos pré-históricos, as pessoas buscam maneiras de dar forma visual a ideias e conceitos, armazenar conhecimento sob a forma gráfica [...]. No curso da história, essas necessidades foram atendidas por diversas pessoas, entre as quais escribas, impressores e artistas. 
Por outro lado, com a Revolução Industrial surge, de fato, a problemática da “classe profissional": a definição de áreas e, por conseguinte, a legitimidade de um tratamento específico para o design de objetos, encarado como distinto do design em geral; a diferenciação de estatuto profissional entre designers, arquitetos, engenheiros e tantas outras profissões.

Do ponto de vista da classe profissional, são predominantes as abordagens que ligam as origens do design a uma determinada escola ou cultura, fixando, por exemplo, a Bauhaus (escola alemã fundada em 1919) como o ponto de partida para quaisquer análises posteriores. O historiador Arturo Carlo Quintavalle (1993, s. p.) argumenta que "[n]a base ou no desenvolvimento destas abordagens está sempre um modelo de classe, a convicção básica de que o design corresponde de algum modo ao proletariado e de que o artesanato se lhe opõe, correspondendo a uma elite". Deste modo, tal concepção de design expressa um zeitgeist particular das tradições anglo-saxônica e vienense do início do século XX, onde imperativos como "a forma segue a função" (Louis Sullivan) ou “adequação ao propósito" (Bauhaus) adquiriram grande repercussão.

Em todo caso, a ideia de que o design é inconcebível antes da cultura moderna da industrialização permanece difundida, sobretudo nos cursos superiores de design no Brasil. O pressuposto-chave para a persistência dessa versão reside na afirmação atualmente generalizada de que a industrialização é um fator ainda novo, que distingue a nossa era de todas as anteriores. Contra tal convicção historicista, devemos recorrer o quanto antes a uma ideia que, conforme atesta Quintavalle, já se tornou senso comum na recente historiografia das técnicas e tecnologias: a de que a produção em série não é uma invenção com um ou dois séculos, e sim, embora de maneiras diferentes, uma estrutura tecnológica que sempre existiu na sociedade.

Sem recuar excessivamente no passado, a questão imediatamente colocada pela moderna historiografia econômica sobre os gregos e os romanos — fato que podemos verificar em qualquer museu arqueológico ou em qualquer livro moderno de história da arquitetura antiga — defende que a produção em série de objetos ou de elementos arquitetônicos era normal, se não mesmo fundamental, para a unidade, para a divisão de trabalho e das funções do Império Romano. Aqui não temos só as jarras e ânforas produzidas em massa, mas a produção massificada de navios e de elementos estruturais para templos, desde sarcófagos a pedras para pavimentação: a exploração de 
várias fontes de energia, desde a fornecida por animais à produzida pela água, tornou possíveis empreendimentos que anteriormente não podiam ser sequer imaginados. Há, evidentemente, quem possa argumentar que o produto de tais esforços não era design, mas como fazer, a nível teórico, a distinção entre "alto" design e "baixo" design e como poderemos pensar que objetos produzidos de acordo com modelos repetidos, multiplicados e feitos "à máquina" podem ser estruturalmente diferentes da moderna produção de objetos a que chamamos design? (Quintavalle, 1993, s. p.)

Logo, mesmo a distinção entre artesanato e produto industrial não diz respeito, em última análise, a uma diferença estrutural dos objetos ou da forma de produzi-los, mas no máximo a uma diferença de escala de produção. Não se trata, evidentemente, de menosprezar as incontáveis inovações tecnológicas e suas repercussões socioculturais que caracterizam a "era industrial", e sim de questionar por que esta questão seria de fato decisiva para a conformação do design enquanto atividade. Afinal, é cada vez mais comum no design, por exemplo, a produção de "baixa-tiragem" de objetos ou livros "numerados", de um modo muito semelhante às pequenas séries de cópias de esculturas ou gravuras - fato que já pode suscitar a questão, sobre a qual trataremos logo mais, da diferença entre o fazer "artístico" e o design.

Alguém poderia objetar, ainda, que o designer somente adquiriu status de profissão, em contraposição ao artesão, a partir da possibilidade de se projetar objetos por meio de máquinas, e não apenas manualmente. Ora, se perguntarmos a um físico o que é uma alavanca, ele responderá que é uma máquina — assim como todos os objetos produzidos por um carpinteiro, um ferreiro ou um desenhista.

A questão de fundo é que, antes da Revolução Industrial, a maioria dos artesãos trabalhava para uma elite e, depois, adaptava-se a novos métodos de produção que possibilitavam maior quantidade de produtos para uma não-elite. Foi com base nessa constatação que Walter Gropius (fundador da Bauhaus) inaugurou o mito do design como produto "democrático", que pode trazer a "boa forma" ao grande público. Não é de se espantar, pois, que a Bauhaus tenha inventado "um estilo ligado à moderna concepção de uma grafia homogênea, a uma 'escrita' convencional tida por unitária" (idem), percurso que se alinhava à pretensão do Círculo de Viena levada a cabo por Otto Neurath em seu Isotype, de se elaborar uma linguagem universal não-verbal. ${ }^{59}$

\footnotetext{
${ }^{59}$ A versão francesa desta mesma pretensão foi apresentada em 1967 por Jacques Bertin (1983), em sua "Semiologia Gráfica". Outros ecos desse mesmo espírito vienense podem ser encontrados em: Rudolf
} 
No extremo oposto a este sonho da "boa forma" — que após a Segunda Guerra adquiriu "valor artístico" na elite norte-americana —, surge uma série de vertentes contrárias à redução do design a meros objetos utilitários, ${ }^{60}$ o que abrirá caminho ao emblemático "funcionalismo de face humana" que Victor Papanek propõe, em 1971, em seu Design para um mundo real. Este discurso do "mundo real" pauta-se, entre outras coisas, na ideia segundo a qual o design não resolve problemas, excetos aqueles por ele criados e, com isso, determina as opções de que as pessoas dispõem. Ora, assim retornamos a outro tipo de salvacionismo, aquele da "responsabilidade social" do design que justificará, por exemplo, uma "política do artificial” a ser defendida por Victor Margolin (2002) — vale dizer, a ideia de que somente o designer é capaz de decidir eticamente acerca de questões como biotecnologia, inteligência artificial etc.

Tendo traçado rapidamente tais discursos, creio ser possível começarmos a problematizar o paradigma, assim identificado, do design. Neste ínterim, recorro ao artigo Um Prometeu cauteloso?, de Bruno Latour (2014), originalmente publicado em 2008 por ocasião de uma palestra que o filósofo francês proferiu num congresso de história do design. De início, Latour explica como a noção de design lhe foi apresentada pela primeira vez: um revestimento "estético" para aquilo que foi projetado por um engenheiro, ou seja, elementos superficiais definidos por questões de gosto e moda. Em outras palavras, design como um "verniz" sem o qual uma cadeira, um livro, um carro, um pacote etc. permaneceria desajeitado, duro ou cru demais.

Embora esta noção "ingênua" possa parecer, à primeira vista, como totalmente contrária àquela segundo a qual "a forma segue a função", na verdade, argumenta Latour, ambas se baseiam numa mesma dicotomia: "de um lado, condicionantes materiais e objetivas e, de outro, condicionantes simbólicas, humanas e subjetivas" (ibidem, p. 11). No entanto, o fato é que "[o] espectro de coisas que podem ser elaboradas através do design é, agora, infinitamente maior" (ibidem, p. 3) do que poderiam supor os funcionalistas: qualquer pessoa com um smartphone sabe que seria absurdo distinguir aquilo que foi elaborado por meio do design daquilo que foi

Arnheim (1992), para quem expressões artísticas devem transmitir percepções universais; Wucius Wong (1998), segundo o qual toda criação visual possui um mesmo propósito de transmitir uma mensagem a partir de parâmetros universais; Donis Dondis (2007), que em sua Sintaxe da Linguagem Visual apostava numa educação visual mais democrática e universal.

${ }^{60}$ A começar pela vertente que se formava na Itália, a partir da década de 1960, em torno do designer Ettore Sottsass e o assim chamado Il Nouvo Design, que influenciará, posteriormente, o movimento Kitsch no design (iniciado pelo designer italiano Alessandro Mendini) e o lema pós-moderno "less is bore" (menos é chato), declamado pelo arquiteto norte-americano Robert Venturi em ironia à famosa sentença "less is more" (menos é mais) de Robert Browning e Mies van der Rohe. 
calculado, arrumado, arranjado, empacotado, embalado, enfeitado, escrito em código etc.

O que isso indica não é tanto uma mudança no entendimento do que significa design, e sim uma mudança na maneira como lidamos com objetos e ações de maneira geral - o que, por sua vez, tende a valorizar e a ressignificar a noção de design. Entre outras coisas, tal mudança colocaria em primeiro plano, em oposição à lógica moderna de "criação a partir do nada", tudo aquilo que já existe e que assim pode ser reparado, reelaborado, repensado. Nos termos de Latour (ibidem, p. 8):

Fazer design nunca é criar ex nihilo. É curioso como os criacionistas estadunidenses usam o termo "design inteligente" como uma espécie de substituto para "Deus, o Criador". Eles não parecem perceber o enorme abismo que existe entre criar e fazer design. Os designers mais inteligentes nunca começam de uma tábula rasa. Deus, o designer, é na verdade um redesigner de algo que já estava lá - e isso é ainda mais verdadeiro para Seu Filho, assim como para o Espírito Santo, já que os dois são enviados para redimir aquilo que havia dado errado... Se a humanidade "foi feita (ou eu deveria dizer "elaborada"?) à imagem de Deus", então ela também deve aprender que as coisas nunca são criadas, mas sim cuidadosa e modestamente reelaboradas. É nesse sentido que vejo a proliferação do termo design como um claro substituto para revolução ou modernização. E o faço também porque há sempre algo ligeiramente superficial no design, algo clara e explicitamente transitório, algo ligado à moda - e, consequentemente, às oscilações da moda -, algo ligado aos gostos e, portanto, relativo. Fazer design é o antídoto para os atos de fundar, colonizar, estabelecer ou romper com o passado. É o antídoto para a arrogância e para a busca de certezas absolutas, começos absolutos e de desvios radicais.

O que esta crítica à razão moderna implica, em última instância, é o reconhecimento da dimensão convencional que o design sempre abrangeu: não se trata de elaborar coisas com base nas "leis da natureza" ou nas necessidades humanas, mas a partir de "detalhes pouco importantes", tais como a moda, os estilos, os gostos. Essa nova ênfase, à medida que seja assim reconhecida, é para Latour aquilo que pode dar força à noção de design no cenário contemporâneo.

Para defender esse ponto, o filósofo argumenta que nunca estivemos puramente jogados no mundo, como queria Heidegger, mas estamos sempre "alienados", isto é, protegidos por uma espécie de "embalagem". Significa que, mesmo na situação mais 
hostil e desconhecida, estaremos sempre já embalados, enredados, situados por significados. Nunca saímos da "caverna" de Platão para o grande "mundo real", mas sempre transitamos de uma caverna a outra, de uma embalagem a outra.

Segundo esse raciocínio, design é uma maneira de reconhecer-se nunca isento de "embalagens". Com efeito, não é que a embalagem "moderna" tenha se arruinado, mas apenas que seu aspecto de embalagem tornou-se mais visível, desnaturalizado, assim como a compreensão de que não existe um lado "de fora" das embalagens. Por conseguinte, o assim chamado "design moderno", funcionalista, revela-se cada vez mais como mero estilo, uma forma de conceber objetos, de apresentá-los, de situá-los em relação ao olhar dos observadores e, acima de tudo, de defender uma política, notadamente de "classe profissional", por meios dos objetos.

Não é improvável, inclusive, que Latour já estivesse ciente não apenas desta reivindicação por um status de "classe", mas também da recente "causa" abraçada pelos designers acerca da "política do artificial" proposta por Margolin (2002). Trata-se de um discurso humanista, cujo caso exemplar é Habermas, segundo o qual não se pode "ir longe demais" no território (proibido) das manipulações genéticas, design de corpos etc., caso se queira preservar nossos ideais de dignidade e liberdade humanas - enfim, a velha (e falsa) dicotomia entre o natural e o artificial, por onde alguns designers viram uma oportunidade para lograr maior legitimidade ética e profissional. Contra esse discurso, Latour elege Peter Sloterdijk - que foi alvo de ataques de Habermas e outros humanistas ${ }^{61}$ - como possível precursor de uma filosofia do design.

Neste ponto, cabe sinalizar que eu não concordo que Sloterdjik seja precursor de uma filosofia do design. Primeiro porque, antes dele, pelo menos Flusser (2010) já pensava nomeadamente numa filosofia do design. Mas sobretudo porque, ao eleger a artificialidade como condição ontológica, Sloterdijk recai no mesmo purismo de uma Natureza às avessas. Afinal, se "o existente existe não como consistência, mas como acontecimento" (Sloterdijk, 2006, p. 167), então "ser significa aparecer", como dizia Heidegger ao referir-se às "coisas mesmas" — o que parece servir mais a uma metafísica da aparência do que a uma filosofia do design.

A importância da noção de "artifício" para uma filosofia do design reside, a meu

\footnotetext{
${ }^{61}$ As reações acentuadas de Habermas se deram por ocasião de uma conferência proferida por Sloterdijk (2000) sobre Heidegger e a biogenética, na qual o filósofo apontou no humanismo reflexos da eugenia nazista e fez a sugestão (bastante sensata) de que a biogenética nos obriga a pensar numa nova ética. Uma compilação dos ataques a esse discurso encontra-se em Habermas, 2004. De modo geral, o debate sobre o destino do ser humano na época da bioengenharia representa uma das maiores polêmicas políticofilosóficas na Europa nos últimos anos.
} 
ver, na ressignificação das próprias noções de materialidade e artificialidade, libertandoas de toda naturalização, autenticidade e purismo. Significa não mais pensar a ação humana - e, por extensão, a ação dos objetos artificiais - como contrária à natureza, pois não é que "[a] bricolagem e as formas de pensar costumeiramente associadas ao design dominaram a natureza. Na verdade, elas são inerentes à natureza" (Latour, 2014, p. 17). Isso vale para a manipulação genética, assim como para a inteligência artificial, para o design de corpos, para gadgets, para modas, para cidades ou para paisagens naturais - tudo isso é design, do início ao fim, portanto natural $e$ artificial.

A importância que Latour enaltece no design reside, em última análise, numa visada hermenêutica segundo a qual artifício e natureza são apenas "palavras". Um design alinhado, portanto, àquilo que Rosset denomina "antinatureza", conceito este que Rogério de Almeida (2012b, p. 84-87) aplica à Educação:

\footnotetext{
Trata-se de reconhecer no artifício (ou na ausência de natureza) a base de um pensamento trágico, que pode ser expresso como uma antifilosofia, no sentido de negar a possibilidade de reduzir os homens, em sua multiplicidade e singularidade, a uma ideia, a um princípio, a uma definição. [...] "Por isso a existência só é aprovada se simultaneamente for aprovado o caráter fictício e artificial" [Rosset] [...] A escolha da aprovação, portanto escolha trágica, não só rechaça a ilusão de uma natureza existente, de um mundo racionalmente ordenado, cujo sentido reside nas coisas, como também afirma a multiplicidade dos modos de existência. Todas as possibilidades humanas, todos os artifícios se abrem ao percurso da vida. A educação, então, deixa de ser um caminho estreito rumo a uma ideia qualquer do que seja humano, e passa a ser arte, artifício, criação de modos diferentes, múltiplos, de existir.
}

O reconhecimento mesmo de que toda interpretação dos fatos está em constante disputa - vale dizer, em constante "design" — é o que, segundo Latour, atribui força à noção de design. Força porque uma ideia de design já se mostra, argumenta o autor, muito mais abrangente do que qualquer ideia de "humano" ou "natureza": a compreensão de que nossa existência é também artifício, de que estamos desde sempre mergulhados em interpretações, ou seja, "embalagens dentro de embalagens".

Sintetizemos nossa problematização até aqui. Vimos que não há uma história do design, e sim uma miríade de histórias, por mais que, por uma questão de classe profissional, queira-se privilegiar certa versão histórica, uma que pressuponha algum propósito para a existência do design: a Revolução Industrial e, por conseguinte, a 
produção em série. Essa ideia de design pode variar, como de fato tem variado ao longo do tempo, mas permanece fundada numa "natureza" que lhe serve de referência como na "política do artificial" de Margolin ou no "mundo real" de Papanek. Em todo caso, trata-se de fazer da utilidade um ideal, e quanto a isso Nietzsche $(2005$, § 260) era incisivo: "A moral dos escravos é essencialmente uma moral de utilidade."

Latour nos mostra que tal referência restringe o design a uma rede mais ou menos homogênea de valores, propósitos, necessidades, funções, responsabilidades etc. De fato, concebido a partir desses pressupostos, o design torna-se não apenas uma política do artificial, mas propriamente uma "polícia" contra os delírios humanos, contra uma ciência imoral, contra políticas e condutas diferentes (das que ele prega). Um design assim orientado, portanto, é promotor da ordem, da civilidade, do homem normal, da "boa forma", das práticas recomendadas, da manutenção do progresso humano. Logo, a esse design interessa "projetar" — premissa de uma natureza ordenada e passível de ordenação — não apenas objetos ideais, mas também um humano ideal, que poderá ser educado por meio do design, e também uma sociedade ideal, que poderá ser construída por meio da transformação das adversidades.

Em maior ou menor grau, esta é a ideologia do design enquanto campo profissional e do conhecimento. Mesmo no caso de propostas recentes como o design thinking ou o design colaborativo etc., cujos métodos dão preferência a pontos de vista múltiplos, procedimentos híbridos, transitórios e heterogêneos, ainda se impingem responsabilidades éticas, justificam-se valores humanos e sociais, enfim, nunca se assume o aspecto artificial de todos os valores. É evidente que, em última análise, jogase conforme as regras do jogo (convenções sociais), sobretudo conforme a lucratividade dos discursos, e não se trata aqui de propor uma contraideologia capaz de neutralizar esta que predomina ou qualquer outra que venha a predominar — "Nenhuma ideologia é mais ou menos verdadeira que outra nem essencialmente melhor [...] já que no horizonte do acaso todas não passam de artifícios" (Almeida, 2012b, p. 86).

O que aqui está em questão é uma visada que nos permita pensar o design não por "ele mesmo", em sua dimensão histórica e profissional, e sim em sua dimensão social, cotidiana, cultural - nas articulações simbólicas que ele produz e engendra. Neste ínterim, levantar um panorama do design enquanto "discurso" foi útil para pontuarmos uma concepção restrita de design em contraposição àquela defendida por Latour, que eleva o termo "design” a um modo de ser contemporâneo. Não será o caso, 
porém, de salientar ou pôr à prova essa tese de Latour, ${ }^{62}$ que somente nos serviu para despojar o design de qualquer referência a um propósito ideal e para colocá-lo, assim, ao lado do reconhecimento trágico do artifício, das convenções.

Em suma, até aqui não fizemos nada além de problematizar o design no intuito de reafirmar seu papel de articulador simbólico. Ocorre que esse papel só aparece de maneira mais clara e contundente quando se considera a aliança do design com a arte. Apresento logo mais, com efeito, uma leitura desta possível genealogia, segundo a qual o design funciona como um dos principais herdeiros da arte, ao menos em seu sentido de Ars - derivação em latim de termo grego árthra (articulação, artifício). É preciso antes, contudo, contextualizar brevemente a questão polêmica que, no campo do design, a mera menção à arte costuma suscitar.

\begin{abstract}
Ao longo do século XX, o lado criativo do design foi sistematicamente subestimado e até combatido por um ideário que ansiava firmar a metodologia projetual em bases supostamente científicas, distanciando-se das artes plásticas e do artesanato. Tal postura reflete uma bagagem intelectual positivista, bastante rasa, herdada do século XIX junto com o marxismo de panfleto que alguns designers e arquitetos modernistas proclamavam a título de ideologia. Em meio aos conflitos ideológicos intensos que marcaram a "era dos extremos" (no dizer de Eric Hobsbawm), o tolo preconceito contra a criação e a criatividade ganhou sobrevida. Primeiramente no movimento construtivista, insinuando-se para o interior da Bauhaus, onde ocasionou grandes divergências, e, dali, para a Escola de Ulm, a noção tola de que “design não é arte" foi ganhando certo pedigree às avessas, simplesmente por força de tanto ser repetida (Cardoso, 2012, p. 245).
\end{abstract}

Embora a relação entre artistas e designers tenha sido sempre estreita (Meggs, 2009), certo "divórcio" foi requerido, no âmbito do design de produto, desde a Bauhaus, cujo manifesto inicial (Cf. Gropius, 1994) convocava os artistas a construírem finalmente uma "arte aplicada à indústria", uma arte a serviço da sociedade. Entre os designers gráficos, o que se admite é, no máximo, o design como "arte comercial" nos termos do designer nova-iorquino Paul Rand (Cf. Helfand et. al., 2010, p. 146-153). Em ambos os casos, pressupõe-se claramente que a arte seja algo não-comercial, algo não-industrial e cujo compromisso ultrapassa os problemas cotidianos. O design, em

\footnotetext{
${ }^{62}$ Contra a qual, particularmente, eu teria algumas reservas, sobretudo em relação à legitimidade daquilo que ele denomina "conduta pós-prometeica" como sendo um modo de ser predominante atualmente.
} 
contrapartida, estaria a serviço do "mundo concreto", das necessidades comerciais e das convenções sociais.

Quer dizer, é como se os artistas não estivessem, desde sempre, a serviço de uma convenção social: a dos xamãs pré-históricos, das forças políticas públicas (o faraó egípcio, o imperador romano, o rei persa, os papas da igreja etc.) e, sobretudo, a dos proprietários privados (os mecenas flamengos, os mercadores venezianos, os burgueses da Revolução Industrial e hoje as fortunas geridas por multinacionais). Ao que tudo indica, pois, a ideia que os designers fazem sobre a arte é aquela que alude a um Belo transcendente, a uma "estética desinteressada" como algo à parte do mundo concreto leitura que se inicia em Platão, acentua-se em Kant e mantém-se intacta no idealismo alemão, na teologia negativa e na teoria crítica (Onfray, 2010, p. 79-98).

Alguém poderia objetar, novamente, em nome da "classe profissional": foi somente na década de 1920 que o termo "design" passa a designar uma atividade profissional que, diferente da artística, restringe-se à indústria e às necessidades civis, comerciais e sociais. Em contraposição, eu argumentaria que o conceito de "arte-pelaarte", de um belo objeto que existe exclusivamente por seu valor estético - o que seria a única concepção plausível que distinguiria a atividade profissional do designer em relação à do artista —, não se desenvolveu senão no século XIX. ${ }^{63}$

Por seu turno, ao reivindicar autonomia, o design também presta contas a modelos abstratos e universais: o que alguns designers chamam de Útil ou Bom mantém uma relação estreita com o Belo transcendente da arte-pela-arte (e/ou com a Verdade, a Natureza e tantos outros ideais metafísicos). Ocorre que nem sempre tais modelos são explicitados; por vezes são atenuados em virtude de novos (e duvidosos) discursos - é o caso, por exemplo, do enunciado acerca de um "design para um mundo complexo", conforme o profere Rafael Cardoso (2012, p. 238):

Se o velho desafio de situar o design como campo profissional não obedece
mais ao procedimento simplificador de dizer o que ele é e não é, então como
devemos fazê-lo? Precisamos pensar com ousadia, imaginar o que o design
pode vir a ser, para além das circunstâncias imediatas e das limitações
passadas. Pensar em design não como um corpo de doutrinas fixo e imutável,
mas como um campo em plena evolução. Algo que cresce de modo contínuo

${ }^{63}$ Vertente cujo exemplo maior talvez seja Théophile Gautier que, em 1856, reivindicou: “nós cremos na autonomia da arte; a arte para nós não é o meio, mas a meta; todo artista que se proponha outra coisa que o belo não é um artista a nossos olhos; não pudemos jamais compreender a separação da ideia e da forma" (Gautier apud Rabelo, 2013, p. 357). 
e se transforma ao crescer. Um caminho que se revela ao ser percorrido. $\mathrm{O}$ design é muito maior e mais dinâmico do que qualquer uma de suas manifestações específicas. Trata-se de uma área por demais complexa e multifacetada para caber em qualquer definição estreita, muito menos para ser reduzida à prática de determinado indivíduo ou escola. Campo jovem, o design encontra-se ainda em fase de aprendizado e experimentação.

Em primeiro lugar, ao se perguntar "então como devemos fazê-lo?" referindo-se ao desafio de situar o design como campo profissional - Rafael Cardoso também reivindica uma autonomia, ainda que "reformulada", do design. Então ele propõe pensarmos com "ousadia”, ou seja, para além das definições estreitas, das manifestações específicas, das doutrinas de determinado indivíduo ou escola. Pois bem, até aqui estamos em pleno acordo. Notemos, porém, que a questão inicial não foi respondida - o que o design pode "vir a ser" ainda fica em aberto. E quando ele sinaliza algum caminho possível, mais adiante, acaba por contradizer-se: "A formação de um designer pensante — legado de Ulm — ainda é uma meta a ser perseguida com seriedade por todos que se interessam pelo ensino do design" (ibidem, p. 241).

Ora, há pouco o design não deveria ser reduzido à prática de determinado indivíduo ou escola; agora a meta a ser perseguida é o legado de Ulm? Mas não teria sido o modelo pedagógico da Escola de Ulm (Hochschule für Gestaltung, Alemanha, fundada após a Segunda Guerra Mundial) que preconizou, segundo o próprio Rafael Cardoso (2012, p. 245), aquela "noção tola de que design não é arte"?

Quer dizer, os ideais categóricos, abstratos e universais nem sempre aparecem nas denúncias a esta ou aquela definição ou proposta, mas geralmente quando se propõe uma alternativa: "Os fundadores da Escola de Ulm sonhavam em gerar designers que fossem também pensadores, e não simplesmente executores de tarefas. Foi um belo sonho" (ibidem, p. 241). O que Rafael Cardoso entende por "designer pensante" é o contrário daqueles designers que ele desqualifica como "menos sérios", que se limitam a tornar as coisas bonitas, agradáveis e fáceis de usar. Donde se pode facilmente deduzir qual seria a opinião de Rafael Cardoso acerca daquilo que Latour enaltece na noção de "design" - artifício, revestimento, verniz estético (o que justifica noções como cake design, design de sobrancelhas, hair design etc.).

Esse tipo de pensamento gera uma atitude projetiva superficial — um design “cosmético", conforme sempre denunciaram os bons designers modernistas, 
com razão. O resultado de criar uma forma boa para um produto ruim é que o usuário, ao descobrir que foi ludibriado, vai descartá-lo com maior rapidez. Mais descarte leva a mais lixo e a mais produção de produtos ruins. É a velha equação da "obsolescência programada" como mola para o crescimento industrial. [...] Mesmo quando [esse designer superficial] exerce a possibilidade de criar, ele raramente tem condição de decidir a serviço de que vai ser usada sua criação. É uma situação lamentável para um campo com potencial para sonhar tão mais alto (Cardoso, 2012, p. 240-242).

Desconfio que este "levar o design a sério" - que era igualmente reivindicado por Papanek em seu Design para o mundo real — seja justamente o obstáculo para que o design seja levado a sério. Porque o design ainda não consegue levar a sério sua própria dimensão estética, cuja potência alguns filósofos já levam a sério. Não se trata de desdenhar dos problemas sociais tão caros a Rafael Cardoso e a toda a tradição modernista - "como se pudesse bastar uma descoberta científica ou uma melhor organização social para arrancar os homens de sua natureza insignificante e efêmera" (Rosset, 2000, p. 30) —, mas de reconhecer que a sociedade é regida, antes de tudo, pelas convenções, pelos costumes, pelas ocasiões e pelos gostos. Também pelas relações de poder e pelas forças econômicas, decerto, mas isso não deixa de pertencer a um conjunto de convenções que não se fundam sobre qualquer alicerce universalmente válido.

Sob o prisma de uma hermenêutica trágica, essa sociedade na qual se insere o design é uma sociedade que não se fundamenta em nada, porque ela mesma é expressão da convenção, seja a dos estratos de classe, seja a dos jogos de poder. Dada de modo narrativo e simbólico, a convenção opera de maneira ficcional: ela não explica nem fornece respostas, mas aciona sentidos possíveis para a experiência vivida, conduzindo valores, comportamentos, generalizações, contradições, dissonâncias e insuficiências. Dessa constatação, não é difícil inferir que cada vez mais é o design que oferece uma imagem do que o homem é socialmente, como compreensão sensível das mediações simbólicas que o perfazem. O ponto de partida e o limite último do design consistem, portanto, em sua dimensão estética, especialmente na articulação simbólica que o design opera, tanto quanto a arte, em direção não tanto a uma sociedade melhor (ilusão moral), mas antes ao melhor do homem: nossa dimensão estético-criativa. 


\subsection{ENTRE ARTE E DESIGN, UM RITUAL DO MESMO PARA O MESMO}

Nietzsche propagou na filosofia contemporânea uma antiga valorização da aparência ante a substância metafísica (Ideia, essência, Verdade). Embora não seja predominante, tal disposição equivale ao reconhecimento das "embalagens" que Latour exaltou em sua acepção de "design". De maneira mais ampla, aponta para certa autonomia de nossos comportamentos, gestos e rituais em relação às crenças, às explicações e aos próprios usos. Por que mulheres usam salto-alto? Por que ainda enterramos os mortos? As ações repetidas e institucionalizadas não são tão "justificáveis" como parecem ser à primeira vista. E colocar em primeiro plano uma dimensão estético-convencional, em detrimento da funcionalidade e dos propósitos, não é de forma alguma irracional ou arbitrário; ao contrário, pressupõe uma mentalidade, um modo de pensar, uma sensibilidade específica.

Trata-se daquilo que impulsiona o design na plasticidade de suas coordenadas estéticas, sempre capazes de articular olhares e experiências diferentes. A impressão que pretendo delinear agora é a de que a noção atual de design guarda alguma consonância com a noção romano-helenística de arte. Tal desconfiança inspira-se em larga medida nas investigações do filósofo italiano Mario Perniola (2000), para quem não seria a Grécia antiga que constitui o ponto de referência por excelência do pensamento filosófico ocidental, e sim a Roma antiga; assim como não seria a Renascença a matriz de nossos modos de ver e representar, mas o período Barroco - revalorizado também por Flusser, Michel Onfray e Jonathan Crary, entre outros.

Ademais, eu particularmente cultivo certo hábito de estudar, em minhas práticas de desenho e aquarela, a estética do período helenístico, na qual se pressupunha uma relação intrínseca entre erotismo e arte. Em especial, o véu que esconde/revela o corpo sintetiza a cena romana: a evocação e a manifestação de uma presença que não pode ser afirmada e significada diretamente. Tal dinâmica da máscara, pela qual uma coisa é ao mesmo tempo outra, concerne uma espécie de intuição que sempre alimentei em relação à ideia de design. Algo que, sob um viés filosófico, poderia ser dito da seguinte forma: tudo se reduz a pó, mas o pó é também um tipo de véu que a tudo envolve — retomarei tal sentença ao final deste tópico, elucidando-a.

Talvez seja útil pontuar, antes de tudo, um rápido percurso etimológico da palavra "arte": entre a téchne grega (conhecimento de um ofício) e o ars latino (habilidade, capacidade de realizar algo) há uma mudança semântica paradigmática. 
Segundo Benveniste (1995), a palavra ars deriva do grego árthra (articulação) e da raiz indo-europeia ar (juntar, aproximar coisas, encaixar), da qual também derivam artus (junto) e articulus (área onde dois segmentos distintos se juntam, se encaixam). Mas se é certo, como diz Benveniste, que a cada categoria da língua corresponde uma categoria do pensamento, uma estrutura teórica mais ampla, é Vilém Flusser (2010, p. 10-11), porém, quem parece indicar com maior abrangência essa mudança semântica, do grego ao latim, acerca da noção de arte:

O termo grego téchne significa "arte" e está associado a tékton, "carpinteiro". O conceito fundamental, neste caso, é a madeira (em grego hyle), que é um material informe ao qual o artista, o técnico, confere uma forma de modo a que essa apareça em primeiro lugar. A objeção de fundo levantada por Platão em relação à arte e à técnica é que estas traem e distorcem as formas inteligíveis (as Ideias) quando as transpõem para o mundo material. Para ele, os artistas e técnicos são traidores das ideias e burlões porque induzem enganadoramente as pessoas a perceber ideias distorcidas.

O equivalente latino do grego téchne é ars, que em grego se traduz por Dreh ("ideia", “expediente", "achado", "truque”, na gíria do mundo do crime). O diminutivo de ars é articulum ("pequena obra de arte") e indica que algo gira, incide, em torno de uma outra coisa qualquer (por exemplo, o pulso). Portanto, ars significa "agilidade", "destreza", e artifex, o artista, designa, em primeiro lugar, um "burlão". O verdadeiro artista é o prestidigitador, tal como o testemunham as palavras "artifício", "artificial”, e inclusive "artilharia”. O termo Künstler sugere que o artista é obviamente uma pessoa "capaz de fazer alguma coisa", na medida em que o termo alemão para arte, Kunst, deriva do verbo können, "poder". Porém, mesmo neste caso, o adjetivo gekünstelt, que significa "artificial", "artefato", "simulado", tem a mesma raiz.

Diferente da téchne, o termo ars indica não mais o trato direto com a matéria, mas uma pequena intervenção do olhar sobre a forma. Ars tende a conotar, portanto, artifício, desvio, estratégia e, em especial, articulação — que, segundo Perniola (2000, p. 227), "implica uma pluralidade de objetos em uma relação ordenada entre eles, mas tal ordem, à qual a operação artística está ligada, não tem conteúdo mítico, nem mera funcionalidade técnica; ela consiste quando muito na construção de um sistema de referências articulado em partes capazes de assumir várias determinações”. Pois bem, vejamos de que modo "arte" assumiu tal conotação. 
Se o mundo grego parece oscilar entre um conceito de arte como verdade e um conceito de arte como mentira, o mundo romano situa-se desde o início além da oposição entre verdadeiro e falso, entre originário e cópia. Mamúrio Vetúrio, o primeiro artista de quem se fala na história de Roma, é autor de uma operação que dissolve o próprio conceito de verdadeiro e falso, exemplo de um comportamento labiríntico por excelência [...] (Perniola, 2000, p. 221).

Segundo Perniola, Mamúrio Vetúrio teria inaugurado a concepção romana de arte (ars) ao anular a distinção platônica entre verdadeiro e falso, original e cópia. No oitavo ano do reinado de Numa Pompílio, conforme escreveu Plutarco (1991), um escudo de bronze havia caído do céu para salvar Roma de uma pestilência que ali se alastrava. Numa então ordenou que o melhor ferreiro da cidade forjasse onze escudos idênticos, no intuito de tornar impossível a quem quisesse roubá-lo adivinhar qual havia caído do céu. A peste cessou imediatamente após Mamúrio forjar os escudos, que ficaram tão iguais que nem mesmo o próprio rei Numa conseguia distinguir o original.

Arte como repetição, não como criação original nem como imitação falsificadora de um modelo incorruptível. Uma repetição tão exata que o protótipo é preservado à medida que, paradoxalmente, se anula enquanto tal. A conduta de Mamúrio como artista não se opõe ao que é dado pelos deuses, ao escudo que caiu do céu, mas tampouco aceita um papel subordinado ou secundário: se nenhuma variação é admitida, essa fidelidade elimina o exemplar único, tornando-o normal, regular, ordinário. "Mas, se perguntamos no quê, em quais conteúdos Mamúrio iniciava, a resposta é tautológica: Mamúrio inicia a Mamúrio, à atividade multiplicadora e dissimuladora, [...] à repetição que descontrói e faz desaparecer aquilo que repete" (Perniola, ibidem, p. 216). Sendo assim, ao invés de sacralizar o que foi dado pelos deuses, a arte de Mamúrio é também profana (antônimo de sagrada) e, justamente por mediar a vontade do rei, é destituída de arrogância e de orgulho, é sem culpa, inocente.

Segundo Eliade, há em diferentes níveis culturais uma ligação íntima entre a arte do ferreiro, a iniciação e a arte da canção, da dança e da poesia. Essa tradição apresenta características marcadamente prometeicas, em que o ferreiro é o herói civilizador, o senhor do fogo, o guerreiro animado pelo calor divino. Mas o ferreiro dos romanos apresenta características completamente diferentes: está subordinado a Numa, não é um criador original, mas autor de uma ação dissimuladora que faz desaparecer o único 
escudo mandado pelos deuses, numa ostentação da multiplicidade, numa espécie de jogo que multiplica por doze o exemplar.

Por tudo isso fica claro o significado do labirinto na fundação da cidade - a cidade pode ser fundada desde que se torne ao mesmo tempo invisível, mediante um ritual protetor: a criação implica ao mesmo tempo um desaparecimento (Perniola, ibidem, 213-214).

Contextualizemos essa cidade que não teve uma verdadeira “origem”, apenas um início: Roma nasce da reunião de estrangeiros, dos sem-pátria que se congregam no refúgio aberto por Rômulo. Só que ser "estrangeiro" em Roma, uma vez que todos o são, não é ser estranho ou marginalizado; ao contrário, instaura uma cumplicidade tácita de não haver identidade originária. ${ }^{64}$ De maneira quase análoga ao gesto de Mamúrio, a fundação de Roma reproduz literalmente um rito sacerdotal etrusco, com o adendo de que Rômulo e seus sucessores apenas repetiam os gestos sagrados sem conhecer em nada seus significados. Trata-se de um "rito sem mito (central)", nos termos de Perniola (ibidem, p. 239): “O importante para Roma é a permanência de estruturas rituais que não têm um ponto de referência mitológico seguro e explícito e que, exatamente em virtude de tal indeterminação, podem adquirir sempre novas dimensões, de acordo com cada ocasião". Eis a mesma relação de simulação - "Roma é desde o início uma cidade simulada, que, no entanto, é indiscernível de uma cidade verdadeira” (ibidem, p. 224) — entre o escudo caído do céu e aqueles reproduzidos por Mamúrio: se o verdadeiro é indistinguível do falso, a própria possibilidade do engano diminui.

Conjugam-se assim indeterminação mítica e precisão ritual: de um lado, os romanos mantinham-se atentos à dimensão cerimonial, aos símbolos, aos gestos; de outro, esquivavam-se de toda significação unívoca e irrevogável destes. Afinal, logro e engano têm necessidade de referir-se a uma verdade, assim como impostores só existem à sombra dos autênticos. "O talismã de Roma, ao contrário, é o resultado de uma operação que adquire uma dimensão política eminente exatamente porque anula todo dado originário, autêntico, étnico" (ibidem, p. 226).

Retomemos a história de Mamúrio, atentando agora à atitude do rei Numa. Quem esconde aquilo que teme que lhe seja roubado normalmente age como um ladrão, tirando o objeto do alcance da vista. Numa, no entanto, fazia questão de exibir seu

\footnotetext{
${ }^{64}$ “A indeterminação, a não-identidade é atribuída pelos romanos à própria Roma, cujo verdadeiro nome - segundo uma antiga tradição referida por Macróbio [Ambrósio Teodósio Macróbio] - era desconhecido" (Perniola, 2000, p. 214).
} 
escudo em público, escolhendo sempre, nos dias de festa, um de seus doze exemplares para ser transportado e celebrado nas ruas da cidade.

A lição de Numa, pois, poderia ser assim formulada: multiplicar a visibilidade de algo é também uma forma de escondê-lo, só que desafiando a própria capacidade ocultadora com uma exteriorização excessiva que rompe a identidade e a unidade do objeto. Essa estratégia ilustra bem o termo latino ars, que difere bastante da téchne grega: enquanto esta dizia respeito não apenas ao fazer técnico, mas também à criação que traz uma obra do nada à presença, ao esplendor do fazer-aparecer (verbo prépein, em grego), o ars remete mais ao grego árthra (articulação), limitando-se a articular uma multiplicidade onde havia um único objeto.

Articulação significa uma relação ordenada entre objetos diferentes. A peculiaridade romana é que tal ordem não possui necessariamente um modelo nem mera funcionalidade técnica; quando muito, ela consistia na construção de um sistema provisório de referências que, por sua vez, eram capazes de assumir várias determinações. Com efeito, a ars romana mantém estreita relação com a noção de evocatio (evocação): uma repetição rigorosamente precisa de rituais alheios cujo significado originário é calado, esquecido, ignorado. "A etimologia ciceroniana de religio, que faz derivar a palavra de relegere (reler), refere-se exatamente a esse aspecto do culto romano" (ibidem, p. 231): não se pretende de modo algum acessar um significado oculto, revelável apenas pela ritualização de um gesto primordial; pretendese, ao contrário, repetir um ritual de maneira tão perfeita que anule o seu significado. "A sua dignidade teórica consiste no fato de ela [a evocatio] reconhecer o caráter mutável, sempre diferente, da realidade histórica; a sua sabedoria prática consiste no fato de se adequar à ocasião e dela se apropriar” (ibidem, p. 211-212).

É bastante significativo que, nessa tradição romana incipiente, a noção de belo tenha se descolado paulatinamente do "resplandecer" grego (tò prépon), daquilo que se impõe ao olhar e brilha por sua virtude originária. O herói homérico, por exemplo, possuía essa beleza grega: sua virtude era inconfundivelmente bela, destacava-se antes de qualquer distinção entre aparência e substância, entre ser e parecer. Entretanto, a partir do momento em que Tucídides (2001) relatou a Guerra do Peloponeso, o herói resplandecente passou a ver-se combatendo uma batalha na qual não dispunha de vantagem alguma — na qual, aliás, era muito provável que sucumbisse.

Poderá continuar resplandecente apenas se vencer a batalha, o que implica saber se adaptar às circunstâncias melhor do que seu adversário, saber melhor do que ele o 
que é conveniente e o que não é, o que se deve fazer em determinado lugar e no momento oportuno. A noção de prépon unia-se, assim, àquela mais antiga de kairós: momento oportuno, ocasião. Embora kairós estivesse ligada originalmente a uma espécie de harmonia do cosmo, Perniola (2000, p. 244-245) aponta-nos que:

[...] é somente em Górgias que a ligação entre conveniente e ocasião se emancipa daquele significado místico, referido à harmonia do cosmo, que a palavra kairós possuía originalmente. [...] Com Górgias, o problema do tò prépon é, essencialmente, o problema da linguagem e de seu poder de sedução (apáte). "A palavra, como o pregão que é proclamado em Olímpia, convida quem quer, coroa quem é capaz". Mas por que o resplandecente deve ter mais apáte, maior poder de sedução e, portanto, maior êxito? A resposta de Górgias é drástica: não existe prépon, não existe resplandecente que não seja conveniente, isto é, que não tenha essa adequação à ocasião, essa força de sedução para impor-se e triunfar.

Se para Górgias não existe prépon sem kairós, essa mesma concepção vai adquirir maior amplitude em Cícero, o grande intérprete e divulgador das teorias gregas no mundo latino. Em seu tratado de oratória, Cícero (1992) declara admirar aquele que sabe o que convém em cada caso, que sabe adequar as palavras a cada pessoa e a cada momento. A ideia romana de belo, com efeito, está muito mais associada à evocatio romana do que ao prépon grego, termo que Cícero traduziu por decorum, anulando qualquer resquício etimológico:

Ora, pela etimologia, decorum não tem nada a ver com prépon. Enquanto prépon remete originalmente à unidade entre visão e efetividade, a palavra latina decorum pressupõe, ao contrário, a ligação entre comportamento e efetividade (Perniola, 2000, p. 252).

Decorum significa convir, combinar, adequar — para Cícero, não se deve falar da mesma maneira nem sempre, nem diante de todos e nem para todos. Donde o belo como decorum obedece à ocasião, a uma circunstância específica - o que não significa total arbitrariedade, pois ainda se refere a um esquema geral ora herdado do passado, ora evocado de uma cultura alheia.

Sintetizemos aqui nossa digressão. De maneira geral, o que se destaca na concepção helenística do belo é a ideia de decorum: uma lógica que, por estar em 
estreita relação com o kairós, com a ocasião, caracteriza-se por assimilar o que lhe aparece como alheio, por adequar-se às diferentes circunstâncias. Por sua vez, a ars romana consiste no triunfo da cópia que se sobrepõe ao modelo. Enquanto a téchne e o prépon gregos remetiam ao originário, ao excepcional e ao resplandecente, a ars latina designava, ao contrário, a repetição e a assimilação dos gestos.

Esses são alguns dos elementos da "estética ritual" que, para Perniola, constitui o eixo da sociedade romana arcaica. Resta-nos esclarecer que o imperativo constante de assimilação, repetição e reprodução "não é restauração, nem reiteração do idêntico. $O$ foco da repetição é o presente" (ibidem, p. 31). Para tanto, é preciso haver o erotismo como operação simuladora e deslocamento, enquanto dinâmica cuja continuidade é sempre outra em relação a si mesma, possibilitando a inserção de uma diferença que, nos termos de Perniola (idem), acontece "do mesmo para o mesmo".

Parte-se de duas concepções distintas cuja oposição Perniola argumenta ser falsa: de um lado, o rebaixamento da dimensão erótica por parte de Platão, em favor da tendência do amor a transcender, a superar, a ir além dos desejos terrenos; ${ }^{65}$ de outro, a reflexão de Bataille ${ }^{66}$ que, para Perniola (2000, p. 64), "é antes uma retomada às avessas do eros platônico do que uma dimensão radicalmente alternativa".

\begin{abstract}
Na obra de Bataille prevalece ora um impulso em direção à unidade, à totalidade, à fusão - que se manifesta na identificação entre o erotismo e a tendência para a perda da própria individualidade —-, ora um impulso oposto, em direção à profanação, ao pecado, ao mal, ao qual são reconhecidos uma dignidade e um valor autônomos. Bataille também, em última análise, não escapa à metafísica, limitando-se a inverter a direção do seu movimento. $\mathrm{O}$ eros não conduz mais à vida eterna das ideias, mas à experiência da morte; não falta, contudo, a sua tendência a superar, a transcender, a ir além; esta se exprime em Bataille na dépense, no excesso, no prosseguimento de uma experiência-limite (ibidem, p. 64-65).
\end{abstract}

Perniola então recorre à Ars amatoria de Ovídio, cuja poesia erótica comporta

\footnotetext{
${ }^{65}$ Em $O$ banquete de Platão (2011), Diotima, uma mulher versada em questões eróticas, define o eros como algo entre o mortal e o imortal, um intermediário entre o humano e o divino, um grande demônio que garante as relações entre os homens e os deuses. $\mathrm{O}$ discurso de Diotima conclui com a descrição do movimento ascensional do amor, que, partindo da beleza dos corpos, vai pouco a pouco cada vez mais para o alto, em direção à contemplação do belo em si.

66 A afinidade fundamental entre a pulsão sexual e a morte reside, para Bataille, no movimento iconoclasta que as anima. Ambas dissolvem a forma, destroem a imagem, violam a bela aparência, à procura de uma verdade mais essencial, de uma pureza mais radical, de um absoluto. Cf. Bataille, 2014.
} 
toda uma série de gestos e rituais, uma prática de moderação (não de excessos), "uma contínua adequação às circunstâncias, às ocasiões, ao dado, um balanceamento do mais e do menos" (ibidem, p. 69). Arte do silêncio e da prudência, a ars amatoria é aqui irredutível tanto à conciliação como à oposição, sendo orientada para a transformação do presente em circunstância oportuna:

\footnotetext{
A provocação amatória implica o conhecimento dos lugares e de tempos oportunos, baseia-se em um saber do tópos e do kairós articulado e complexo, desenvolve-se mediante deslocamentos feitos de improviso e oportunidades que não se devem deixar escapar (ibidem, p. 77).
}

O erótico consiste nesse deslocamento que, contudo, deve permanecer imperceptível, num jogo de sinalizar veladamente aquilo que não deve ser explicitado. Daí a importância de "um trânsito entre o visível e o invisível, entre a veste e aquilo que ela cobre" (ibidem, p. 89). Um trânsito entre ocultar e revelar, um ver-não-ver entre a veste e o corpo, o que se manifesta com mais afinco na escultura e nas artes figurativas, conforme Perniola (ibidem, p. 84-126) demonstra em especial na erótica barroca do "revestir", em contraposição ao nu exaltado no humanismo renascentista neoplatônico.

Destarte podemos compreender que, no movimento do "mesmo para o mesmo", sublinhado por Perniola na estética romana, o "mesmo" não quer dizer "igual", porque implica introdução de uma diferença, ainda que mínima, que é tanto mais contundente quanto menos for notada. Sobretudo em se tratando de erotismo, ao menos enquanto ars amatoria, o que se repete é a abertura à ocasião, pautando-se na consciência de que "viver é um repetir, um retomar, um voltar a buscar algo que já tenha ocorrido" (ibidem, p. 30) - aquilo que Nietzsche chamará de amor fati, apropriação e assimilação do passado desejando sua repetição, que será diferente.

Esta sensibilidade ritual pode também ser entendida, a meu ver, como uma expressão da hermenêutica trágica: a evocatio pela qual os romanos absorviam os rituais alheios constitui um modo, uma linguagem, uma possibilidade de falar do trágico, isto é, um compreender que privilegia a ocasião (kairós) em detrimento de um sentido fixo. Nasce daí uma atenção totalmente profana e mundana em relação às convenções, às representações e às explicações, um modo de ser não orientado pela revelação ou estabilização de verdades, mas pela adesão estética que põe em circulação uma miríade de sentidos possíveis frente à falta de sentido do mundo. "A queda da verdade fez circular o jogo das interpretações" (Almeida, 2015a, p. 6). 
Creio ser este tipo de sensibilidade que, finalmente, está implicada na ideia de design: a consciência de que estamos esteticamente inseridos no mundo, sob a mediação de sentidos, interpretações, ficções e convenções. O mundo é aparência de mundo, é o que aparece, o que se dá a ver, onde qualquer novidade, diferença e criação é somente possível por apropriação, assimilação, repetição e deslocamento "do mesmo para o mesmo". Tal redundância é afirmada na plasticidade dos rituais que, à maneira helenística, permanecem sempre capazes de mudar seus conteúdos e suas finalidades. Tanto é que, se levarmos em conta as conotações mais cotidianas — design como embelezamento, revestimento, verniz estético —, não encontraremos nada além de um design como "expressão de um gosto".

\footnotetext{
Esse "gosto", pelo qual a filosofia trágica designa simultaneamente o que é chamado ora talento, ora gênio, ora potência criativa ou capacidade produtiva, não significa uma aptidão em transcender o acaso em criações que escapariam ao acaso, mas uma arte (originalmente sofística) de discernir, no acaso dos encontros, aqueles que dentre eles são mais agradáveis: arte, não de "criação", mas de antecipação (prever, por experiência e delicadeza, os bons encontros) e de retenção (saber "reter" sua obra num desses bons encontros, o que significa que se pode apreender no voo o momento oportuno) (Rosset, 1989, p. 183).
}

Sendo assim, mesmo contrariando definições "oficiais" de alguns especialistas cujos bons propósitos ultrapassam a opinião do senso comum, não vejo no design a mínima relação com funções que estariam "para além das aparências”. Aliás, qualquer argumento que se dê para distinguir a arte do design (ou vice-versa), mesmo em função de convenções como a das classes profissionais, parece cada vez mais carecer de fundamento. Afinal, como constata Favaretto (2011, p. 105), “A prática artística está desterritorializada, para bem e para mal; isto é, para o exercício das singularidades ou para a efetuação da razão comunicativa, quando não para o oportunismo modista". Ou ainda, nos termos de Rogério de Almeida (2015a, p. 133): “Liberada da ilusão, a arte dissemina-se nos mínimos gestos e já não é mais arte, um procedimento específico de criação operado pelo gênio do artista, mas transcriação estética, manipulação casual das aparências". Com relação ao design, Flusser (2010, p. 11) é assertivo: 
entre si, nenhum deles é pensável sem os outros e todos têm a sua origem na mesma visão existencial do mundo. Todavia, esta correspondência interna foi negada durante séculos (pelo menos desde o Renascimento). A cultura burguesa moderna fez uma nítida separação entre o mundo das artes e o mundo das técnicas e das máquinas, pelo que a cultura foi cindida em dois ramos que se excluem mutuamente: o ramo científico, quantificável e "duro", e o artístico, qualificativo e "flexível". Esta divisão perniciosa começou a tornar-se insustentável por volta do fim do século XIX. A palavra design inseriu-se nessa brecha e fez de ponte entre os dois ramos, na medida em que o termo exprime uma conexão interna entre arte e técnica. Por isso, na época contemporânea, design indica, grosso modo, o lugar em que a arte e a técnica (juntamente com as suas respectivas modalidades científicas e críticas) coincidem de comum acordo e abrem caminho a uma nova forma de cultura.

O que nos é pertinente, por ora, reside em outra colocação de Flusser (ibidem, p. 13): "O termo design conseguiu conquistar um lugar-chave na linguagem quotidiana porque começamos (talvez com legitimidade) a deixar de acreditar que a arte e a técnica são fontes de valor e a darmo-nos conta da intenção (design) que as sustenta." Se em vez de "intenção", porém, pensarmos em termos de "aspectos rituais", uma relação entre o design e a ars romana começa a se tornar visível. Para ficarmos com um exemplo pontual: a experiência da morte já não parece ser tão religiosa ou angustiante quanto se supõe. Nas narrativas coletivas e na pesquisa científica, a preocupação é cada vez mais dirigida aos estados intermediários, que se configuram como formas de vida artificial — desde os vampiros da literatura, passando pelos "replicantes" da ficção científica até os pacientes terminais mantidos vivos pela tecnologia médica.

Ora, faz todo sentido falar em "design" de corpos ou da morte, sobretudo quando se trata da mistura entre o orgânico e o inorgânico, entre a corporeidade e as coisas, entre o que suscita perturbação e o que desperta entusiasmo. Ao menos é nesse sentido que filósofos como Flusser e Latour compreendem o processo graças ao qual parece que as coisas adquirem qualidades humanas e vice-versa, no qual as noções de "design" e "artifício" tomam o lugar das de "natureza", "providência" e "vontade de Deus". Poderíamos até pensar, inspirando-nos em questões foucaultianas, num "design da sexualidade", que tende a prescindir de polaridades como a do masculino-feminino; ou ainda num "design de si", atento mais aos espetáculos privados e aos acidentes de percurso do que aos grandes eventos históricos. Seja como for, 
É inútil escapar ao "jogo de Mamúrio": o essencial é continuar, apesar das pauladas. O ensinamento do ferreiro Mamúrio é oposto ao dos outros "senhores do fogo" da área indo-europeia: não o Wut, o furor religioso, a cólera que aterroriza os inimigos, mas a calma, a indiferença, o mimetismo; em uma palavra, a caerimonia (Perniola, 2000, p. 261-262).

De acordo com Perniola, o que mantém a correspondência entre hoje e o mundo helenístico não são tanto os valores, as noções ou os discursos, mas antes o papel dos rituais, das cerimônias, das instituições, não como obstáculo à experiência e à expressão humanas, mas, bem ao contrário, como condições de uma existência compartilhada. Sob tal perspectiva, fica evidente que mesmo a revolta e a transgressão também são formasrituais que já se encontram prontas; em contrapartida, o novo não nasce senão por meio de imperceptíveis reformulações do velho, mínimos desvios do conhecido, design "do mesmo para o mesmo". Portanto, é pelo design que se constitui, desde a ars de Mamúrio, o cerne de nossa experiência estética, na articulação de sentidos e sensibilidades conforme cada ocasião.

Com isso obtemos as condições para poder definir o modo particular pelo qual o design desempenha uma articulação simbólica: do mesmo modo que a ars romanohelenística. Arte como repetição, ritual, imitação criativa, e não como criação original ou como imitação falsificadora de um modelo incorruptível. Portanto artifício, distorção, estratégia. Diferentemente da téchne grega, o fazer design não consiste no trato direto com a matéria, tampouco em criação ex-nihilo que traz uma obra do nada à presença, e sim numa pequena intervenção do olhar sobre a forma.

Seu modo de operar é "erótico", isto é, decorre da dinâmica da máscara: a evocação e a manifestação de uma presença que, em vez de ser afirmada e significada diretamente (como no caso, em geral, da retórica publicitária), é apenas emulada por meio de uma veste, um invólucro, um véu que só se faz notar "silenciosamente", pela repetição e assimilação dos gestos. Não se trata, contudo, de uma "indumentária invisível", pois o design atua menos no registro da funcionalidade, das necessidades, dos propósitos, e mais na superfície estético-convencional, das aparências, do "ritopelo-rito". Por conseguinte, o que define design não é "produção em série", mas a evocatio, reprodução que dissolve o modelo, ritualização de convenções e signos cujo significado originário é calado, esquecido, ignorado.

Também não é o caso, convém sublinhar, de um "design artístico" — sem outra 
função além de gerar fruição estética — nem de um "design publicitário" — como discurso ostensivo de difusão de mensagens. O objeto de design conforma tão somente a aparência sempre ambígua dos rituais: ousadia e cautela, atenção e indiferença, atitude e passividade. "[...] não são realidades incompatíveis entre as quais é obrigatório escolher de uma vez por todas, mas situações a ser apreciadas no momento oportuno" (Perniola, 2000, p. 43). Multiplicidade de valores que se encarrega da passagem do presente para o presente, movendo-se pela força das convenções. Donde poderia resultar, por parte dos designers, certa postura ética do decorum ou da adequação: o gosto pelo acaso, pela representação, pela ficção que se sabe ficcional - em suma, saber se adaptar à circunstância, à ocasião, ao momento oportuno.

Talvez muitos se incomodem com a amplitude simplificadora desse arremate, com a ideia de o design ser "só isso" — neste caso, persiste a expectativa ilusória de que ele deveria ser algo mais especial, sublime, superior. Retomemos então minha provocação inicial: tudo se reduz a pó, mas o pó é também um tipo de véu que a tudo envolve. Design é tudo isso. De um lado, estamos inseridos esteticamente no mundo, isto é, desde sempre enredados em mediações, ficções e convenções. De outro, o mundo é aparência de mundo, uma imagem casual não interpretável, mas que pode ser significada e interpretada aos ser articulada com outras imagens, algum véu a mediar os sentidos, alguma forma a ser ritualizada.

A um só tempo, somos seres forjados para e pelo design.

\subsection{ARTICULAÇÕES SIMBÓLICAS}

Partindo da premissa de que é somente no interior de uma cultura e em contato com outras culturas que significamos a existência, o design é aqui entendido como um modo de compreender que vale mais pela forma de enunciação, expressão, adequação e retórica (dimensão estética) do que pela possibilidade de seguir funções ou de resolver problemas que estariam "além das aparências". Mais do que isso, aposto na ideia de que a amplitude que o termo "design" tem adquirido - conforme atestam Flusser, Latour e outros filósofos - faz comparecer ao palco contemporâneo novas formas de estar no mundo, formas pautadas pela assimilação ritual e que tendem a valorizar mais o registro estético e menos o da funcionalidade, das necessidades e dos propósitos.

Neste último tópico do trabalho, começo por situar a experiência estética 
articulada pelo design - que sugere especialmente um simulacro — para, em seguida, descrever a articulação simbólica operada pelo design, esboçando assim uma nova proposta (sob o prisma de uma hermenêutica trágica) de filosofia do design.

Estamos esteticamente inseridos no mundo. A busca de sentido, o logos, a razão, o conhecimento manifestam-se hoje como forma e formulação estética. Relação de gosto, a estetização contemporânea marca o retrocesso do pensamento como indicador de verdade, como referência e referente de um referencial e um referido externos ao próprio conhecimento, um princípio qualquer que transcendesse e permitisse seu salto. Preso em si mesmo, o pensamento não morre nem desaparece: torna-se estético (Almeida, 2015a, p. $5)$.

O que significa estar esteticamente inserido no mundo? Mediante o dado trágico da existência - o acaso que faz existir e deixar de existir tudo o que existe - e a impossibilidade de transcender ou alterar esse dado trágico, a única ação possível é acrescentar acaso ao acaso. O próprio fato de existirmos já produz tal acréscimo. Mas para a vida constituir-se como experiência é preciso adentrar o registro do imaginário, por onde forjamos um sentido para as ocasiões, para nós mesmos e para o mundo. "A experiência é o que nos passa, o que nos acontece, o que nos toca. Não o que se passa, não o que acontece, ou o que toca. A cada dia se passam muitas coisas, porém, ao mesmo tempo, quase nada nos acontece" (Larossa, 2014, p. 18).

Por sua vez, "[do] grego aisthesis ou aestesis, estética significa a capacidade de sentir o mundo, compreendê-lo pelos sentidos, é o exercício das sensações" (Almeida, 2015a, p. 134). Enquanto disciplina filosófica orientada ao estudo da arte e do belo, a Estética foi cunhada no século XVIII pelo filósofo alemão Alexander Baumgarten. A partir do século XX, porém, vemos o vasto desenvolvimento de uma estética não mais limitada ao estudo da arte e do belo (Perniola, 1998). Dentre uma miríade de exemplos, Deleuze talvez seja um dos pensadores mais emblemáticos no que concerne à ideia de que todo sentir/pensar está, desde o início, já engajado num modo de expressão estética. “A estética, assim, deixa de ser uma experiência controlada pelas obras de arte (fruição) e passa a dominar todas as dimensões da vida mediada" (Almeida, 2015a, p. 152).

Em sua conferência $O$ que é um ato de criação?, Deleuze (2012) argumentou que imaginação, razão e afetos operam como motores que movimentam a experiência estética. Significa que tanto criar quanto assimilar, traduzir e compreender são 
expressões de um "gosto", de sensações, de impulsão ou repulsão, sendo a experiência estética uma constante na relação criativa do homem com o mundo. Ocorre que essa relação criativa não é apenas estética, mas também hermenêutica, por envolver (junto aos gostos e sensações) mediações, interpretações e obras:

\footnotetext{
Compreender assemelha-se a traduzir na mesma proporção em que ler um gesto, um texto ou uma imagem implica conferir-lhe sentido. A compreensão decorrente das leituras de mundo (suas traduções) é um ato de interpretação. No entanto, esse processo elementar não passa de um dado de base da relação do homem com o mundo, é a forma primeira pela qual o homem opera uma mediação com o mundo e com os outros mas que não constitui ainda suas obras.
}

\begin{abstract}
As obras advêm de um processo secundário e mais complexo, de decantação, destilação, reelaboração, perlaboração e materialização desses numerosíssimos dados da compreensão, da leitura do mundo. É quando o mundo disforme, amorfo, indiferente e incompreensível transforma-se em obra. Enunciar um mundo, renunciar a um sentimento do mundo ou anunciar sua aprovação é transcriá-lo, seja como outro mundo (duplo), seja como mundo-aqui (amor-fati) (Almeida, 2015a, p. 137).
\end{abstract}

Enquanto mediação simbólica, podemos chamar de "obra" tanto um romance, um filme ou um monumento arquitetônico quanto coisas mais voláteis e efêmeras: uma combinação de roupas, um buquê de flores, um corte de cabelo etc. Assim como a música, o cinema e a literatura, pois, o design pode ser entendido como mediação ao mesmo tempo estética e hermenêutica que se dá "menos por invenção que por (trans)formação, criação de formas que formam, informam, deformam, reformam a experiência de estar no mundo" (ibidem, p. 139). Embora o design não trabalhe com configurações lineares, como textos literários ou enredos cinematográficos, ele não deixa de forjar, à sua maneira (articulação simbólica), obras diversas.

Retomo logo mais este ponto sobre a articulação simbólica obrada pelo design; por ora, detenhamo-nos no fato de que, assim como aderimos aos sentidos, aos gostos, às mediações, advêm da mesma esfera imaginária certas convenções que, em contrapartida, por vezes operam como gramática ou instituição reguladora dos gostos como se a experiência estética fosse restrita a determinados espíritos e gostos esclarecidos. Por exemplo, são muitos os pensadores contemporâneos (como Bauman, 
Lipovetsky e Finkielkrault) que denunciam uma "estetização do mundo" consumismos, espetacularização, narcisismo - como sintoma de um vazio existencial, de um modo de vida decadente. Mas o denunciam em nome de um "valor maior", de uma experiência "verdadeira" que lamentavelmente estaria ausente no mundo.

\begin{abstract}
Não se trata de acusar o pensamento de pensar errado, uma vez que os sábios têm descrito com muita exatidão o que se passa no mundo hoje: excesso de informação, fragmentação da vida social, consumismo exacerbado, descentramento identitário, proliferação dos mecanismos tecnológicos de controle, avanço das desigualdades sociais, fundamentalismo religioso, terrorismo, declínio dos recursos naturais etc. Mas os sábios do passado também elaboraram suas listas de aberrações e apesar dos diagnósticos corretos a vida prosseguiu com seus males e prazeres. Porque o problema não está em apontar o que vai mal no mundo, mas em fazê-lo em nome de um valor maior que está ausente do mundo. A questão, então, é se o pensamento é capaz de pensar o aqui sem medi-lo com a régua do que está além, se é capaz de pensar o pior, não por gosto masoquista, mas como condição de aprovação da existência (Almeida, 2015a, p. 147).
\end{abstract}

Não é apenas a ampliação da estética enquanto campo de estudo, em paralelo ao progressivo esgotamento das definições restritivas da arte, que tem incomodado alguns sábios contemporâneos, mas também o alargamento da dimensão hermenêutica: se nunca antes o conhecimento esteve tão disseminado e acessível, a "verdade" se torna uma questão de interpretação, de opinião. Para Vattimo (1996), ${ }^{67}$ por exemplo, o mundo converteu-se em interpretação e, com isso, perdemos o mundo verdadeiro: esvaziamento de sentido, niilismo consumado, enfraquecimento do pensamento. Ora, se há alguma coisa que esteja se esvaziando ou se ausentando, não é o mundo (verdadeiro ou não), mas talvez certos imaginários, como o da razão emancipadora e da reflexão crítica. Em contrapartida, outros imaginários ganham força ou tornam-se mais visíveis: o da estetização, o da espetacularização, o do simulacro.

Por sua vez, em seu livro Simulacros e simulação, Jean Baudrillard (1991) assinala sua insatisfação com os "estilos de vida" contemporâneos, com a estetização mundana e com a proliferação do simulacro que, para ele, só expressa uma alienação generalizada, o esvaziamento do sentido e um desejo desesperado de camuflar esse

67 “[...] a generalização da noção de interpretação, até coincidir com a mesma experiência do mundo, é realmente o resultado de uma transformação no modo de conceber a verdade que caracteriza a hermenêutica como koiné [idioma comum]" (Vattimo, 1996, p. 16). 
vazio. Tal avaliação depreciativa do simulacro, ainda recorrente na crítica cultural, procede de uma exigência romântica por uma realidade mais pura ou autêntica; servenos ao menos como pretexto, entretanto, para um reexame da experiência do simulacro, que me parece ser em larga medida articulada pelo design.

Simulacro é a simulação que simula a si mesma. Enquanto "simulação" significa imitação de algum modelo, "simulacro" representa algo que não possui nenhum equivalente, refere-se a si mesmo. Essa diferença concerne a duas concepções básicas de "representação": que as imagens estão ligadas a referentes (a ideias ou a coisas reais do mundo) ou que as imagens são autorreferenciais (pois só representam outras imagens). A imagem de "felicidade" prometida por uma marca de refrigerante, por exemplo, é autorreferencial, logo simulacro. Denegar esse tipo de imagem implica, a meu ver, uma iconoclastia similar à de Calvino, para quem, no século XVI, as imagens sacras são nocivas porque, ao referirem-se a si mesmas, diminuem o temor a Deus. No mesmo século XVI, porém, a experiência espiritual relatada por Inácio de Loyola afastava-se tanto da iconofilia ortodoxa quanto da iconoclastia protestante (Durand, 2010). Para o jesuíta, as imagens não geram ídolos e tampouco correspondem à esfera divina, devendo então ser apreciadas por si mesmas, assim como o mundo e seu espetáculo. Tal experiência simulacral, na qual "o valor das imagens não mais depende da realidade e da dignidade de um protótipo metafísico” (Perniola, 2000, p. 139), encontrou solo fértil no barroco ${ }^{68}$ e nada tinha a ver com o "esvaziamento" que, não raro, é também atribuído ao período seiscentista. ${ }^{69}$

\begin{abstract}
Iconofilia e iconoclastia convergem na pretensão metafísica de estabelecer uma relação entre a imagem e o original; quer essa relação seja de identidade, como na iconofilia, quer de diferença, como na iconoclastia, pouco importa: o importante é o pressuposto metafísico, comum a ambas, que afirma a existência de um original, materializado no ícone ou revelado na visão. No entanto, a imagem produzida pelos meios de comunicação de massa não possui original — trata-se de uma construção artificial que não possui protótipo. Por isso, quando as duas posições tradicionais em relação às imagens são estendidas à imagem contemporânea, resultam evidentes sua inadequação e sua impotência. [...]
\end{abstract}

\footnotetext{
${ }^{68}$ No que tange à história da arte, Perniola (2000) identifica no barroco o fim do valor metafísico no figurativismo e a possibilidade de utilizar como simulacro qualquer imagem e qualquer estilo. Por sua vez, o "teatro filosófico" barroco pode ser caracterizado como simulacro. Cf. Onfray, 2009, p. 13-36.

69 Benjamim, por exemplo, encontra no período barroco a primeira manifestação de esvaziamento das imagens, uma vez que elas não mais irradiavam um sentido unívoco. Cf. Benjamin, 1984.
} 
O simulacro não é ícone nem visão, ele não mantém uma relação de identidade com o original, com o protótipo, nem implica laceração de todas as aparências e a revelação de uma verdade pura, substancial. O simulacro é uma imagem que não possui protótipo [...]. Iconófilos e iconoclastas consideram-no sinônimo de ídolo e, como tal, prope nihil - quase nada. Essa avaliação depreciativa depende inteiramente da pretensão metafísica de capturar uma realidade absoluta presente ou futura. Por essa razão, os iconófilos condenaram a idolatria tanto quanto os iconoclastas; para eles, fixar uma linha de demarcação precisa entre imagens verdadeiras e falsas, entre ícones e ídolos, constituiu uma premissa essencial, uma garantia de identidade (Perniola, 2000, p. 133-134).

Por romper a relação direta entre imagem e original (iconofilia) sem, no entanto, cair na desvalorização das imagens (iconoclastia), o simulacro nada mais é do que a afirmação do valor da imagem enquanto imagem. Não significa, contudo, tomar a imagem como original - como no caso da appropiation art, que na década de 1980 reivindicava a originalidade da cópia-pela-cópia (como uma nova arte-pela-arte) —, pois o simulacro "implica a negação tanto de um protótipo externo como da tentação de considerar a imagem um protótipo; ele está, por isso, relacionado com as técnicas de reprodução industrial da imagem, a começar pela impressão" (ibidem, p. 140). A televisão, por exemplo, pode oferecer uma variedade incomparavelmente maior de imagens de um dado acontecimento do que aquela que o indivíduo poderia ver se estivesse presente no local. Com efeito, os meios de comunicação de massa podem propor uma imagem que é muito mais profícua e contundente do que aquela oferecida por qualquer realidade e que, no entanto, não adquire uma originalidade própria.

Como experiência, o simulacro consiste em aprovar a imagem sem hipotecá-la a outra coisa, pois sob o prisma do simulacro não há lugar para a relação original-cópia. Daí que, como insistia Nietzsche (2006) em O crepúsculo dos ídolos, a ideia de um "mundo verdadeiro" é a maior ilusão de todas. Vimos, em sua crítica genealógica, como as noções de "original" e "verdadeiro" são pautadas no descrédito a toda dimensão mundana e na apologia do que é colocado idealmente acima dessa dimensão - e disso deriva uma das grandes objeções de Nietzsche (1998, III, § 12):

De agora em diante, senhores filósofos, guardemo-nos bem contra a antiga, perigosa fábula conceitual que estabelece um "puro sujeito do conhecimento, 
isento de vontade, alheio à dor e ao tempo", guardemo-nos dos tentáculos de conceitos contraditórios como "razão pura", "espiritualidade absoluta", "conhecimento em si" —; tudo isso pede que se imagine um olho que não pode absolutamente ser imaginado, um olho voltado para nenhuma direção.

Liberada da originalidade, a vida cotidiana não mais se subtrai de um modelo ideal, mas se intensifica nos mínimos gestos, na manipulação casual das aparências, no espetáculo fugaz de ver e ser visto. De que modo uma fotografia seria menos original do que o mundo visto? Em que medida um documentário é mais real do que um filme de super-heróis? Uma vez que as pessoas já sabem do aspecto "fantasioso" daquilo que as entretém, por que continuam a se entreter? Se tudo o que vemos somente adquire sentido ao ser compreendido, resulta vã a pretensão de ir além do simulacro: fingimento que se sabe fingido, aparências que nada têm a esconder.

Não se trata de mera fantasia ou de justificar alguma ilusão, pois a adesão ao simulacro é reforçada na explicitação de seus artifícios e por sua capacidade de assumir sentidos múltiplos de acordo com cada ocasião. Seu valor é o de não possuir valor inerente, de modo que não há engano possível além da expectativa de engano sabemos que a felicidade não vem de algum produto que a promete, mas nada impede que acreditemos nisso provisoriamente; acreditar sem acreditar. No fluxo cotidiano, pois, a escolha não mais se dá entre a verdade e a mentira, mas entre uma imagem que se vende como verdade e, cada vez mais indistinguível desta, uma imagem que é dada como imagem. Deduzir a partir daí que tudo está se tornando mais "falso", reitero, implica a exigência de uma contraparte "verdadeira". Por que uma imagem não seria real, se é por meio dela que nos instauramos no espaço tangível do mundo? Um número seria mais ou menos real? A internet seria mais ou menos real?

A vantagem do simulacro é a de anular tais distinções. Pois o simulacro não reside apenas nas imagens, nos produtos e nos discursos, mas no próprio mundo, que é somente o que aparece, o que se dá a ver, e nunca algo que aponta para outro mundo, outra verdade. Sob o prisma de uma hermenêutica trágica, a aparência coincide com o real e o simulacro nos situa nele. Simulacro é o que aparece, o que se dá a ver: tatuagens coloridas sem significado, cenários manipulados no Photoshop, emoções instantâneas em protestos políticos ou em parques de diversão - tudo converge para o real e termina no real. Eis a experiência estética articulada pelo design. 
A identidade traduz-se por narrativas, transcriadas e atualizadas em determinadas situações da vida cotidiana. As tatuagens, os metais, as próteses e as vestimentas artificializam os corpos revelados como arte.

Estamos, portanto, além do bem e do mal, mas também além do belo e do feio. [...] o contemporâneo marca a saída da história para o ingresso na estética: sem liberdade, sem salvação, sem destino e sem finalidade (ou ainda com eles mas como vestígios de um modo de operar que se apaga), o homem lança-se ao espaço da mistura, da mixagem, da analogia, da tradução. O domínio contemporâneo é o da transcriação e os homens exibem-se como obras.

Os itinerários de autoformação, sempre provisórios e inacabados, são os meios pelos quais construímos, elaboramos, configuramos, inventamos, imitamos, traduzimos o que somos. Não são as nossas obras, mas somos nós como obras (Almeida, 2015a, p. 187).

No trecho acima, ao falar de itinerários de "autoformação", Rogério de Almeida enfatiza a trajetória individual mediante experiências singulares. Para reconhecermos a inserção do simulacro como experiência estética articulada pelo design nas trajetórias de autoformação - tarefa que esboço a seguir —, é preciso levar em conta menos a formação enquanto complexo institucional, no qual o aprendizado se dá em níveis e esferas, e mais o registro das "experiências sensíveis [que] formam os modos de viver e interpretar o mundo" (ibidem, p. 179). Nesse âmbito estético, formação é sempre autoformação: a aprendizagem convive com a desaprendizagem; os valores, com a suspensão de valores; os conceitos e conhecimentos, com o fluxo constante de intensidades afetivas, porque "é na experiência individual de cada corpo — seu modo de sentir, de ser afetado - que as formas de mediação da cultura contribuem na formação das formas de lidar com a experiência imediata da vida" (ibidem, p. 183). Autoformação é este território de passagem pelas mediações, pelas pequenas verdades provisórias e pelo exercício de gostos e estilos, pelo qual participamos efetivamente de um mundo que é indissociável dos sentidos, dos afetos, das aparências, das convenções.

Desse modo, não é o aspecto drástico, traumático ou maravilhoso que caracteriza a experiência, mas o movimento lento que nos atravessa diariamente e do qual mal nos apercebemos, até o momento em que esse movimento adquire forma, por meio da reflexão (autonarrativa), da conversa 
(co-narrativa) e mais concretamente nas narrativas (verbalizadas, fotografadas, filmadas, desenhadas, escritas...). A experiência não é, necessariamente, uma ruptura, um acontecimento, pode ser tão somente o resíduo de fluxos cotidianos, mais ou menos intensos, por vezes não inteiramente conscientes, mas que em dado momento desabrocha, se revela, aparece [...] (Almeida, 2015a, p. 149-150).

Esse movimento que "adquire forma", próprio da experiência estética, coaduna com um dos aspectos que Flusser (2010, p. 19) atribui ao design: "a matéria no design [...] é o modo como aparecem as formas". Significa que a experiência articulada pelo design se dá menos pelo conteúdo do que pela forma. Não deixa de haver um significado partilhado, mas este é da ordem do sensível: o que nos liga aos rituais, às aparências e mesmo às instituições é menos uma questão racional, lógica, funcional e mais uma questão convencional, simbólica, formal. "São essas formas que me formam, é o arranjo dos encontros [...] que constituem os itinerários pelos quais nos reconhecemos e nos situamos no mundo" (Almeida, 2015a, p. 173). Quer dizer, no âmbito da experiência estética é também a forma que prevalece sobre o significado: penso que alguma coisa vai acontecer num dado momento, mas a forma como essa coisa acontece ou deixa de acontecer "reconfigura" meu pensamento sobre ela. Ou seja, entre o acontecimento acontecido e o acontecimento vivido, muitas vezes não há variação alguma de significado, mas antes de forma, de perspectiva, de modo de olhar.

Forma como facies, figura, species, aquilo que se liga ao aspecto, à passagem dos sinais, dos gestos, dos movimentos. Enquanto os significados são elementos sempre abstratos, podendo ser tomados como "verdade" a qualquer momento, a forma é, bem ao contrário, aquilo que consolida um ritual, portanto inseparável dos afetos, da própria situação, daquilo que nos é oferecido. E aqui podemos retomar a questão do simulacro, que é também mais forma do que conteúdo: ao recusar a distinção metafísica ente realidade e aparência, entre cópia e original, o simulacro se justifica não em nome de si mesmo - como "coisa mesma", aquilo que se mostra em si mesmo, nos termos de Heidegger —, e sim em nome da aparência, de um mundo "desfabulado".

É por isso que o estado contemporâneo da estética - deslocado da arte para a vida - pode favorecer a desfabulação do mundo: todas as narrativas, discursos, instituições e boas intenções perdem o estatuto de verdade e se proliferam como ficções às quais aderimos sem crença. $O$ mundo 
desfabulado mostra-se nu, sem duplo, sem transcendência, sem finalidade ou necessidade. Seus excessos todos — beleza, vida animada, instabilidades climáticas, rupturas geológicas — revelam o incessante trabalho do acaso, sua abertura para o eterno movimento, o atrito dos encontros (Almeida, 2015a, p. 186-187).

Eis a inserção do simulacro como experiência estética articulada pelo design, nas trajetórias de autoformação: na experiência desestabilizadora do simulacro, as pretensas verdades mostram-se como ficções, formas, artifícios. O simulacro não pretende ser algo além daquilo que é, aparência de mundo, mas expõe e potencia esse caráter de aparência. Tal operação é levada a cabo por meio da articulação simbólica, mas numa modalidade específica, a do design, que é dada pela forma, pelo ritual, pelos gestos e aparências. Sendo forma, o simulacro não corresponde diretamente a objetos e produtos, mas aos processos de mediação e formação que envolvem produtos, marcas, estilos de vida etc. E se o "dado relevante da experiência são os fluxos e as intensidades, o modo como nos afeta, nos marca, nos torna o que somos" (ibidem, p. 149), o simulacro do design deve abranger tantos aspectos quantos são os modos de existência, acolhendo todas as possibilidades, todas as formas, todos os papeis.

O termo "simulacro" é aqui empregado, vale sublinhar, conforme o descreve Mario Perniola (2000), isto é, como experiência que dissolve a oposição metafísica entre original e cópia, verdadeiro e falso. De imediato, é uma noção que me parece útil para abandonar por definitivo a ideia de que o design, conforme defendido no decorrer do século XX, estaria a serviço do "mundo concreto" e de suas necessidades reais ideia na qual a dimensão estética relegava-se a um registro secundário no design, como algo insignificante ou mesmo à parte do mundo concreto. Até porque, se a concepção comum que os não-designers fazem do termo "design" — artifício, revestimento, verniz estético - não se alterou ao longo de mais de um século (pelo contrário, é cada vez mais reforçada), então é preciso ao menos rever ou ampliar o sentido de design.

Ao mesmo tempo, contudo, essa noção de simulacro não é nada recente - da perspectiva de Perniola, trata-se de uma experiência que guarda afinidade com a ars romana e com a estética barroca. No ritual romano-helenístico, o simulacro corresponde à "dinâmica da máscara", pela qual uma coisa é ao mesmo tempo outra. Por sua vez, na experiência seiscentista o simulacro era exaltado, segundo Perniola, como aquilo que subvertia os contrários um no outro e, ao mesmo tempo, mantinha-os em sua oposição: 
aquilo que era tido como sério podia ser expresso de maneira frívola e vice-versa; a fama e a riqueza eram cultuadas tanto quanto a experiência da morte etc. De modo geral, portanto, o simulacro aponta para um modo-de-ser ritual que adere a um mundo como palco em aberto, uma peça a ser interpretada e encenada, o gosto pelo acaso, pela simulação, enfim, um jogo que se sabe ficcional.

Creio que esse tipo de experiência estética, ao desembocar no design, aciona novas formas de estar no mundo de maneira análoga ao ritual pelo qual os romanos abriam-se às ocasiões e ao espetáculo mundano. A novidade hoje não é o espetáculo, mas o aspecto acessível do espetáculo: a conduta corrente é escrever "bom dia" em alguma rede social, como quem espiona por trás da cortina minutos antes do início do show. Somos ali representados não necessariamente por nossas grandes conquistas ou feitos notórios, mas sobretudo em pequenos "sketches" do cotidiano, elencando notícias, imagens, trilhas sonoras, uma citação filosófica, um comentário irônico, uma indireta em aberto, uma confissão não endereçada a ninguém em específico.

Cada indivíduo é a estrela, o herói, o autor de sua própria vida — seja esta vida levada a sério ou não, para o deleite ou inveja dos olhares alheios. Uma vez que existe alguém nos assistindo, imaginariamente ou não, somos designers de nós mesmos. Não jogamos tanto com palavras ou ideias, mas com ícones, fotografias, vídeos, estilos, representações de si. Trata-se de um ritual que se abre à medida que as coisas que nos cercam (imagens, objetos, lugares e pessoas) se coordenam, se conectam, se compõem. Há decerto uma função mimética nesse processo, mas que não consiste em meramente reproduzir uma forma, e sim em reapresentá-la no ato mesmo de "adequar-se" a ela, num constante simulacro que, assim, se atualiza.

Em outros termos, o design perfaz um ritual diário de recortar, assimilar, organizar dadas mediações de acordo com nossos gostos e com cada ocasião. E à medida que alguém recorta, assimila e organiza algo, aquilo que foi recortado, assimilado e organizado muda tanto quanto quem o recortou, assimilou e organizou. Com efeito, não se trata tanto de expressar uma "visão de mundo", mas antes de fazer diferentes modos de olhar expressarem-se uns pelos outros, num processo que é sempre ambíguo porque procede por símbolos, por simulacros, por formas que não têm significado senão na própria rede de relações a que se ligam.

Insistindo neste caráter simbólico, processual e hermenêutico, podemos enfim compreender o design como articulação simbólica: uma (re)tradução constante, por meio da forma, que abre o mundo para a pluralidade das interpretações, para o vigor do 
simulacro, para a intensidade dos fluxos afetivos. Tarefa de "dar forma", nos termos de Flusser (2010), ou maneira de "dar a ver" o mundo — o que implica reconhecê-lo como aparência de mundo - por meio das mediações que nos conectam a ele. Nesses termos, seria possível pensar, ainda que de maneira imprecisa, em dois "níveis" de design: um design amplo, ritualizado no cotidiano (na eleição de certas aparências, encontros, estilos e gestos), e um design circunscrito à articulação dos rituais cotidianos (por meio de produtos e peças gráficas).

No primeiro nível, trata-se do "design de si", do narrar-se a si mesmo, o que pode voltar-se à noção nietzschiana de "obra de arte": exercício de afirmação da vida pela ficção que se inscreve nela e que a reescreve, neste caso, por meio de gestos, formas, representações, máscaras e rituais. O segundo nível, por sua vez, diz respeito à articulação de "modos de olhar" que entram em circulação no primeiro nível. Esse tipo de trabalho, que é propriamente do designer, não consiste em fundar, justificar ou legitimar ideias ou discursos, mas em estabelecer conexões ou ressonâncias de uma experiência a outra, sempre a partir da superfície pela qual temos acesso a toda experiência: a representação, a imagem, a aparência das coisas.

Para "criar", portanto, o designer não depende tanto de uma ideia rigorosamente inédita, velada, que então seria "revelada" tal como um cientista "descobre" uma nova representação ou forma de representar um "fato da natureza". O que se cria no design, em sua articulação simbólica, depende mais do "representar" em si, no sentido de reconfiguração e rearranjo das coordenadas disponíveis, como uma espécie de caleidoscópio que produz sempre uma nova combinação a partir de si mesmo. Em outras palavras, cria-se mais a partir da captura e do agenciamento e menos a partir da descoberta ou da invenção; o desafio não é tanto ter uma ideia, e sim conseguir expressá-la, conferir-lhe uma forma. Para tanto, do mesmo modo que não se faz música só com sentimentos, mas efetivamente com notas musicais, o design lida com elementos visuais a serem conjugados simbolicamente, sempre a partir de coordenadas finitas (a exemplo de uma escala de cores) e de convenções estabelecidas (o que envolve desde regras de composição visual até comportamentos ritualizados).

Isso nos leva a retomar uma premissa da hermenêutica trágica: a de que não há nada a ser efetivamente criado, somente acaso que se acrescenta ao acaso. De um lado, portanto, design implica não um criar ex-nihilo, a partir do nada, mas uma articulação simbólica, uma intervenção nos modos de olhar; de outro, é apenas frente ao acaso e às convenções que somos impelidos a criar. Sob esse viés, fica evidente que quaisquer 
"novidades" seguem formas-rituais já consolidadas: o novo não nasce senão por meio de imperceptíveis reformulações do velho, mínimos desvios do já conhecido, redesign das ocasiões. Não significa que nada de diferente é criado, como num eterno remix das mesmas coisas, e sim que a diferença somente se introduz no deslocamento "do mesmo para o mesmo", na repetição e acréscimo de acaso.

Na esfera do design-de-si, não obstante, nossas articulações simbólicas também ocorrem ao acaso, quando certas ocasiões adquirem forma e ressonância mediante uma imagem, um gesto, alguma forma que se repete e que de repente se faz notar. É quando nos deparamos, por exemplo, com algum detalhe insignificante, alguma imagem ou objeto que "faz aparecer" uma situação pela qual já passamos, mas que agora se abre por um percurso diferente, um lugar diferente, pessoas diferentes. Nesse sentido, o design atua como uma máscara que me permite reconhecer-me no que me acontece, como uma analogia fortuita. Como aquilo que, conscientes disso ou não, importandonos ou não com isso, nos leva a relacionar e recombinar uma miríade de sensações, estilos e gostos. Como uma capacidade de olhar e experimentar as mesmas coisas de maneiras diferentes, de deslocar e multiplicar as formas numa passagem do mesmo para o mesmo, do presente para o presente, de um olhar a outro.

Afinal, é somente na superfície do cotidiano, nas situações planejadas ou imprevistas, imaginadas ou constatadas, que as experiências irradiam em todas as direções, num movimento repetitivo e por contiguidade da forma. No entremeio de uma situação e outra, de uma experiência e outra, articula-se uma miríade de simulacros feitos de aparências, de cores, de letras, de formas - enfim, de uma série de gestos rituais, convencionais, prefixados, típicos, amaneirados. E, à medida que esse espaço intermediário se explicita, também o mundo explicita-se como aparência de mundo, inaugurando um modo de estar no mundo pelo qual podemos experimentar tanto a ausência de sentido (dado trágico do real) como a multiplicidade de sentidos possíveis (imaginário). Nesse modo de estar no mundo, o design delineia-se nas máscaras que vestimos a todo instante, na formação dos gostos e desgostos, nas performances sociais, nos estilos de vida - sendo tudo isso experimentado como simulacro, isto é, num comportamento orientado ao dado, à ocasião, ao momento oportuno. 


\section{CONSIDERAÇÕES FINAIS}

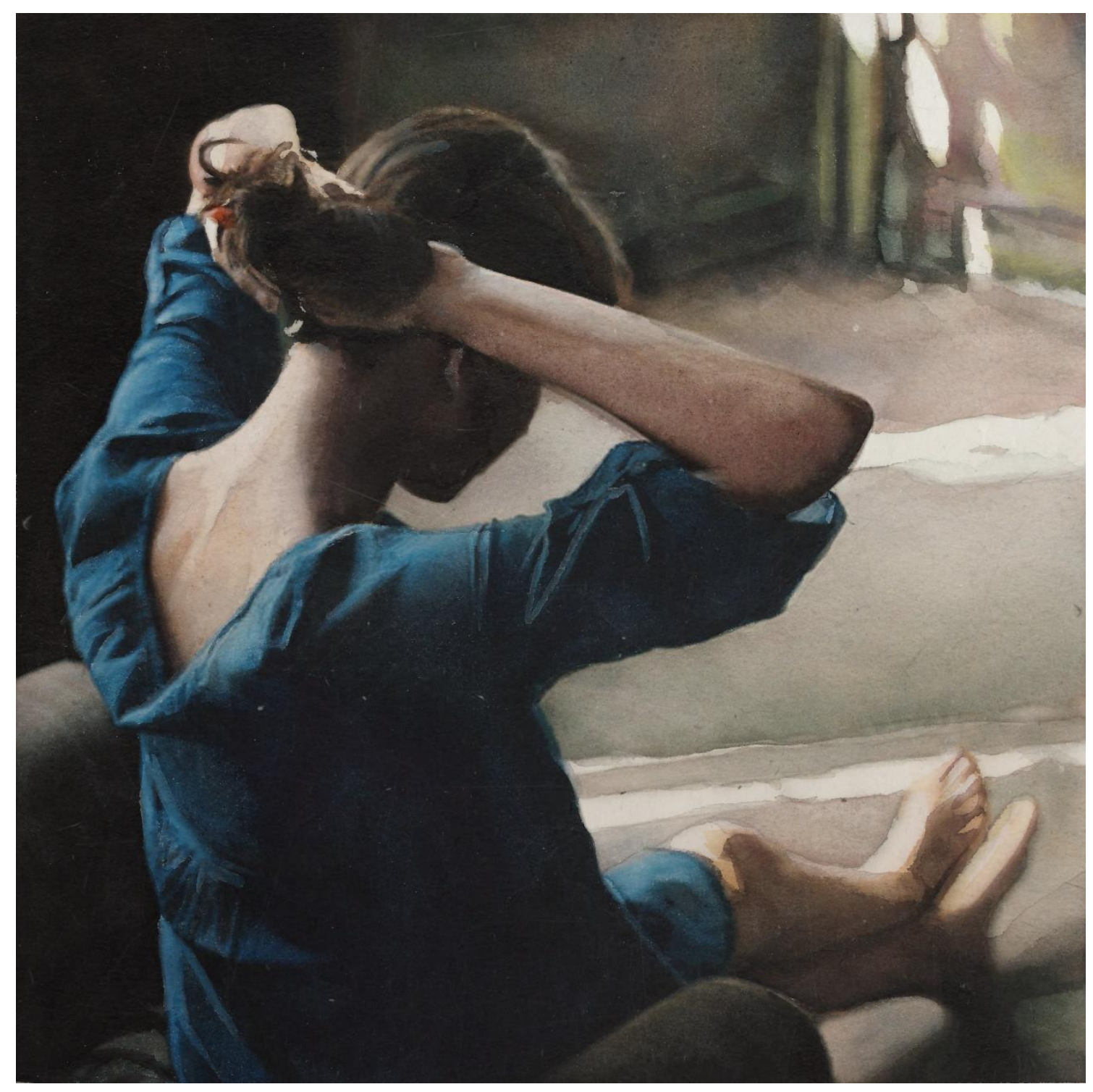

Viver conforme a ocasião. Governar, argumentar, tudo deve se dar de acordo com a oportunidade. Querer quando se pode, porque a ocasião e o tempo não esperam.

— Baltazar Gracián, A arte da prudência.

O presente estudo é marcado pela suspeita de um design como ficção — não no sentido de mentira, mas no sentido de fingere, feitiço, coincidência de algo que adquire forma enquanto é compreendido. Mais do que isso, parte-se da suspeita de que o design diz respeito a um "modo de estar" no mundo, talvez não predominante, mas cada dia mais visível: o gosto pelo acaso, pela representação, pela ficção que se sabe ficcional.

A primeira questão a ser respondida, neste ponto de chegada de nosso percurso, 
serve-nos como recurso retórico: o que diferencia esta noção de design, aqui defendida, das máscaras e totens que integravam os rituais ancestrais? Nada, exceto a amplitude da circulação e do acesso das novas representações e rituais, fazendo comparecer ao palco contemporâneo, talvez de modo comparável ao helenismo, uma multiplicidade de valores.

Por isso a importância deste trabalho não reside tanto em dizer o que é design — em última análise, design é um nome novo para uma conduta antiga que reaparece revigorada -, mas sim em propor uma filosofia do design que forneça um quadro conceitual apropriado a abarcar a amplitude que o termo design tem adquirido. Neste trabalho, procurei integrar a filosofia trágica à hermenêutica simbólica, compondo assim uma "hermenêutica trágica" para amparar uma filosofia do design que, por sua vez, julgo ser propícia não apenas ao design, como também a certas vertentes da Educação - como a linha de pesquisa Cultura, Organização e Educação e outras similares - e da Filosofia - ética e estética contemporânea e investigações de novas formas de "estar no mundo", como as desenvolvidas por Rogério de Almeida, Flusser e Perniola.

De fato, trata-se de um esboço não sistemático, tampouco colocado à prova ou validado por fórmulas ad hoc. É apenas um exercício de criação filosófica conforme Deleuze a definia e defendia. Um dos aspectos mais relevantes na elaboração desta tese, parece-me, é justamente a proposição de um "modo de olhar" que, de um lado, denuncia certa tendência moralizadora de querer fixar e universalizar determinados valores (como o funcionalismo no design) e que, de outro, sugere uma estética da existência orientada pelo design. Deste último aspecto, dois pontos se sobressaem: (1) a relação criativa do homem com o mundo não é apenas estética, mas também hermenêutica, por envolver (junto aos gostos e sensações) mediações, interpretações e obras; (2) a articulação simbólica operada pelo design torna-se central por abranger as ideias de uma "imitação criativa" (na esteira da ars romana), de simulacros que não escondem nada mas que nos situam numa existência sempre mediada e explicitam um mundo como aparência de mundo, e de um "espelhamento" dos gestos pela repetição ritual, o que tende a valorizar mais o registro estético-convencional, do "rito-pelo-rito", e menos o da funcionalidade, das necessidades e dos propósitos.

Penso que há uma miríade de outras dimensões a serem exploradas sob este prisma, como, por exemplo — tenho em mente as que pretendo levar adiante —, a ficção do "tempo", que me parece marcada por um "design" de adaptar-se à ocasião, ao momento oportuno e o âmbito da visualidade e dos modos de representação, como 
aprofundamento da noção de simulacro que atribuo ao design. Com isso quero sinalizar que, devido ao caráter macro do argumento desenvolvido nesta tese, foram deixadas de lado esses e outros tantos "focos" que também seriam relevantes a uma filosofia do design sob o prisma de uma hermenêutica trágica. Acredito, contudo, que o percurso aqui trilhado foi bastante fecundo enquanto esboço filosófico para esses possíveis desdobramentos mais focados e aprofundados.

Espero, por fim, ter contribuído na compreensão do design como aquilo que faz advir uma expressão (nos termos de Spinoza) ou um estilo (no dizer de Deleuze): vozes que se redefinem a cada ocasião e que não dependem de nenhuma essência para demarcar um modo singular de ser e agir no mundo. De um lado, a ars romana se mantém pela redundância das narrativas e pela recorrência dos rituais. De outro, o design criou-se na ambiguidade entre o que se "diz ser" e o que se "faz aparecer", entre novidades, repetições e redescobertas da vida contemporânea. Implica uma vontade de querer aquilo que foi e aquilo que é, de encarar - como diz o Zaratustra nietzschiano — cada "foi assim" como um "assim quis que fosse".

A um só tempo, o design que percorremos, na verdade, é que nos percorre: o reconhecimento de que somos uma vivente não-necessidade de existir, que nos solicita um mesmo modo-de-ser ficcional, recomeçado a cada dia. 


\section{POSLÚDIO: Carrossel de aquarela}

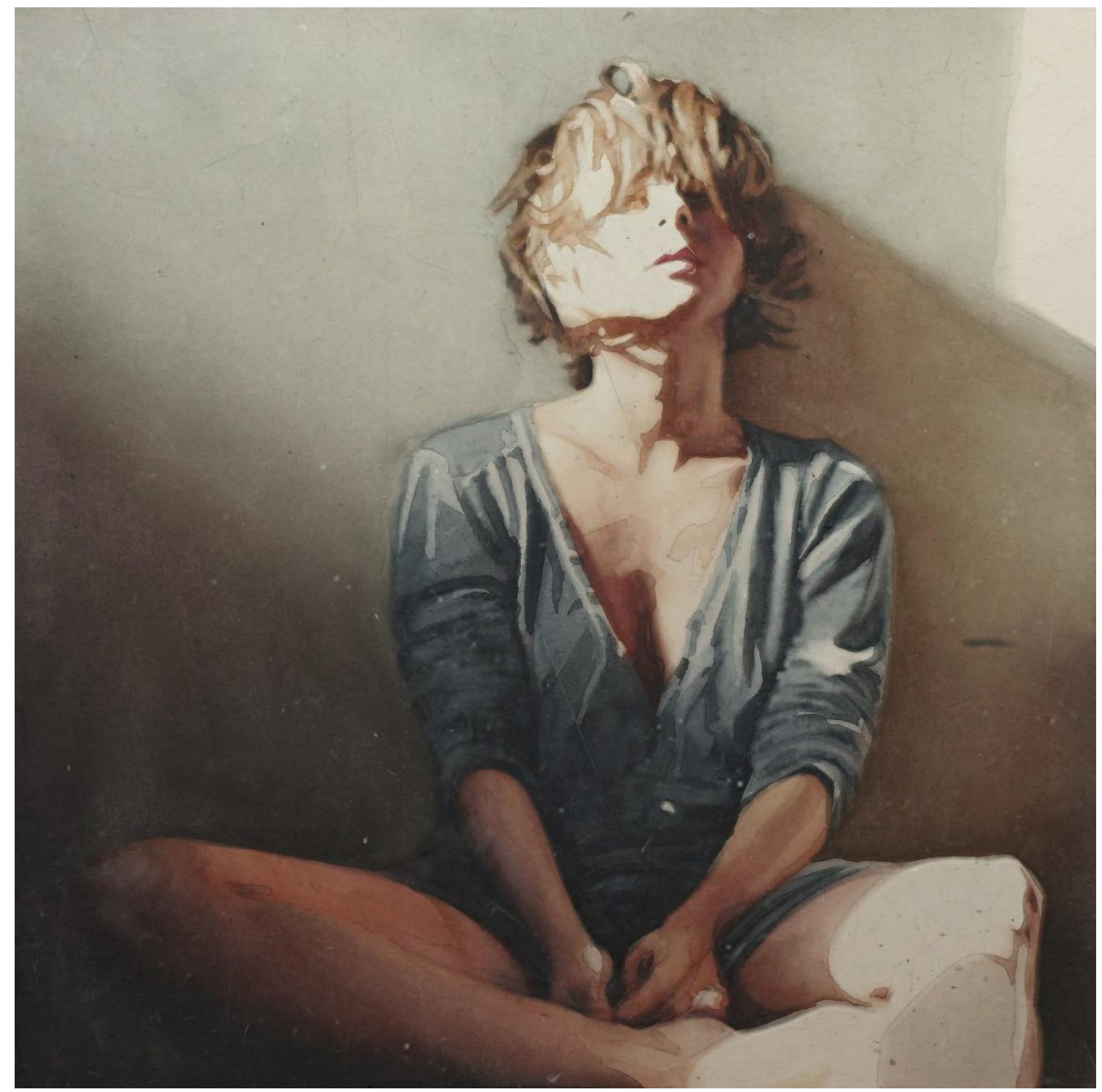

You never really lived until you have read something about yourself that someone put on a fiction.

— The Salesman [autor fictício].

Ulisses acorrentado ao navio sorvia o alucinante canto. Já sabendo do final, mas ansioso por mudanças perceptíveis somente aos desatentos. Não é sempre, mas o panorama tende a dissolver rígidas contraposições. Meninos e meninas posando para as fotos, tatuagens coloridas, fingimento que se sabe fingido. Calma e ansiedade. Intimidade entre desconhecidos. Alguém dizia "é estranho", e havia em seus olhos o imenso espanto de tudo saber, mas de nada dizer. 
É tudo verdade, natal de janeiro a dezembro, nenhuma novidade. As calçadas são feitas de pedras falsas. Mimetismo vertiginoso graças ao qual o que é espúrio, derivado e replicado, se liberta do autêntico, do originário, do único. Prescindir das palavras para chegar ao alcance das coisas. Flagrante de um olho que olha outro olho. Você gosta deste som, né? Pega, é presente. Trouxe para você.

Rigorosa precisão, sem mistério nem enigma, como quem se põe inteiro em tudo o que faz, ainda que esse tudo seja pouco, sem nada a perder porque toda perda foi antes uma dádiva. Não resta imprecisão alguma no cansaço da telefonista do atendimento ao consumidor. Ou na perseverança do professor de ensino-médio público que apanha quinze reais por hora/aula. Na sisudez do empresário tão bem-sucedido e tão carente de um gesto solidário. Na aflição da médica-residente em não conseguir dar atenção aos filhos. Nos filhos abortados para não repetirem nosso destino.

Nada disso é incerto e continuamos a viver sem explicações suficientes para abarcar tanta precisão. É como escolher um bom perfume para encobrir, não por muito tempo, os incontáveis orifícios que nos encobrem. Se por um lado podemos dizer "dancemos" e nem por isso ficamos alegres, podemos dizer, por outro, que ficamos alegres ao nos flagrarmos dançando. A grande justificativa é a de que não há o que ser justificado, tudo é aprendido e ensinado apenas para que continuemos a agir como se soubéssemos de alguma coisa. De resto, apenas movimento.

Para pensar no movimento, não é preciso concentrar-se. É preciso já estar em movimento. No giro de um carrossel, a velocidade tende a desfocar a paisagem. A não ser que se olhe para o centro do carrossel - mas não há o que se ver por ali. Melhor é agarrar a barra de ferro e inclinar a cabeça para fora. Segurar um garoto pela mão e, agora com nitidez, sentir-se leve e devagar, tão desprovido de passado quanto o menino que o guia: tudo converge para o presente e termina no presente. 


\section{REFERÊNCIAS BIBLIOGRÁFICAS}

ALMEIDA, R. de. A literatura e seu aspecto formativo. Revista Religare, UFPB, João Pessoa, v. 8, p. 127-138, 2011. Disponível em:

<http://periodicos.ufpb.br/ojs2/index.php/religare/article/view/12496>. Acesso em: 11 jul. 2015.

. Meia-noite em Paris. In: ALMEIDA, R.; FERREIRA-SANTOS, M. (orgs.).

Cinema e contemporaneidade. São Paulo: Képos, 2012a, p. 39-52.

Artifício e natureza: a multiplicidade dos modos de existência. In: PAGOTTO-

EUZEBIO, M. S.; ALMEIDA, R. de (orgs.). Sobre a ideia do humano. São Paulo:

Képos, 2012b, p. 73-87.

. Considerações sobre as bases de uma filosofia trágica. Diálogos

Interdisciplinares, UBC, Mogi das Cruzes, v. 2, p. 52-63, 2013. Disponível em:

<http://www3.brazcubas.br/ojs2/index.php/dialogos/article/view/37>. Acesso em: 11 jul. 2015.

Da inutilidade do ensino de Filosofia na escola. In: ALMEIDA, R.; PAGOTTOEUZEBIO, M. S. (orgs.). O que é isto, a filosofia [na escola]?. São Paulo: Képos, 2014.

O mundo, o homem e suas obras: filosofia trágica e pedagogia da escolha. Tese de livre-docência depositada na Biblioteca da Faculdade de Educação da Universidade de São Paulo. São Paulo: FE-USP, 2015a.

O imaginário trágico de Machado de Assis: elementos para uma pedagogia da escolha. São Paulo: Képos, 2015 b.

ALMEIDA, R.; FERREIRA-SANTOS, M. (orgs.). Aproximações ao imaginário: bússola de investigação poética. São Paulo: Képos, 2012.

ARNHEIM, R. Arte e percepção visual: uma psicologia da visão criadora. São Paulo: Pioneira, 1992.

ASSIS, M. de. Contos de Machado de Assis, v. 3: filosofia. Rio de Janeiro: Record, 2008 .

AUSTIN, J. L. How to Do Things with Words. Oxford: Oxford University Press, 1975.

BACHELARD, G. A dialética da duração. São Paulo: Ática, 1988.

BARTHES, R. A semântica dos objetos. In: . A aventura semiológica. São Paulo: Martins Fontes, 2001.

BATAILLE, G. Sobre Nietzsche: voluntad de suerte. Madrid: Taurus, 1986. 
O erotismo. Belo Horizonte: Autêntica, 2014.

BAUDRILLARD, J. O sistema dos objetos. São Paulo, Perspectiva, 2008.

Simulacros e simulação. Lisboa: Relógio D’Água, 1991.

BECCARI, M. Articulação simbólica: uma abordagem junguiana aplicada à filosofia do design. Dissertação (Mestrado). Universidade Federal do Paraná: Curso de Pós-

Graduação em Design, 2012.

BECCARI, M.; MIZANZUK, I.; PORTUGAL, D. B. Existe design? Indagações filosóficas em três vozes. Teresópolis: 2AB, 2013.

BENJAMIN, W. Magia e técnica, arte e política (Obras escolhidas v. 1). Trad. Sérgio Paulo Rouanet. São Paulo: Brasiliense, 1994.

Origem do drama barroco alemão. São Paulo: Brasiliense, 1984.

BENVENISTE, E. O vocabulário das instituições indo-européias Volume II: Poder,

Direito, Religião. Campinas: Editora da UNICAMP, 1995.

BERGSON, H. A evolução criadora. São Paulo: Martins Fontes, 2006.

BERTIN, J. Semiology of Graphics. Madison, Wisconsin: University of Wisconsin Press, 1983.

BORI, P. C. L'Interprétation infinie. Paris: Éditions du Cerf, 1991.

BOURDIEU, P. A distinção: crítica social do julgamento. São Paulo: Edusp, 2007.

BOUTINET, J. P. Antropologia do projeto. Trad. Patrícia Chitonni Ramos. Porto

Alegre: Artmed, 2002.

CARDOSO, R. Design para um mundo complexo. São Paulo: Cosac Naify, 2012.

CÍCERO, M. T. Do orador e textos vários. Porto: Resjurídica, 1992.

COLLI, G. O nascimento da filosofia . Campinas: Editora da UNICAMP, 1992.

DELEUZE, G. Diferença e repetição. Rio de Janeiro: Graal, 1988.

. A ilha deserta. São Paulo: Iluminuras, 2006.

O que é o ato de criação?. In: DUARTE, R. (org.). O belo autônomo: textos clássicos de estética. Belo Horizonte: Autêntica, 2012.

DELEUZE, G.; GUATTARI, F. O que é a filosofia?. São Paulo: Editora 34, 1992.

DONDIS, D. A. Sintaxe da linguagem visual. São Paulo: Martins Fontes, 2007.

DURAND, G. A imaginação simbólica. Lisboa: Edições 70, 1995.

. As estruturas antropológicas do imaginário. São Paulo: Martins Fontes, 1997.

O imaginário: ensaio acerca das ciências e da filosofia da imagem. Rio de

Janeiro: Difel, 2010.

GALLE, P. Philosophy of design: an editorial introduction. Design Studies, v. 23, n. 3, 
2002, p. 211-218.

GRACIÁN, B. A arte da prudência. Trad. Ivone Castilho Benedetti. São Paulo: WMF Martins Fontes, 2009.

GRONDIN, J. L'universalité de l'herméneutique. Paris: PUF, 1993.

GROPIUS, W. Bauhaus: Novarquitetura. São Paulo, Perspectiva, 1994.

HABERMAS, J. O futuro da natureza humana. São Paulo: Martins Fontes, 2004.

HELFAND, J.; HELLER, S.; POYNOR, R. (orgs.). Textos clássicos do design gráfico.

São Paulo: WMF Martins Fontes, 2010

HIERRO, R. D. El saber trágico: de Nietzsche a Rosset. Madrid: Ediciones del Laberinto, 2001.

HONNETH, A. Luta por reconhecimento: A gramática moral dos conflitos sociais.

Trad. Luiz Repa. São Paulo: Ed. 34, 2003.

FAVARETTO, C. Deslocamentos: entre a arte e a vida. Revista ARS (PPG-Artes Visuais - USP), v. 9, p. 94-109, 2011.

FLUSSER, V. O universo das imagens técnicas: elogio da superficialidade. São Paulo: Annablume, 2008.

. Uma filosofia do design: a forma das coisas. Lisboa: Relógio D’Água, 2010. FOUCAULT, M. A ordem do discurso. São Paulo: Loyola, 1996.

As palavras e as coisas: uma Arqueologia das Ciências Humanas. São Paulo: Martins Fontes, 2007.

FREIRE-COSTA, J. O vestígio e a aura: corpo e consumismo na moral do espetáculo. Rio de Janeiro: Garamond, 2005.

FREUD, S. Obras completas, vol. XI. Rio de Janeiro: Imago, 1970, p. 55-124.

FRY, T. Becoming Human by Design. London: Bloomsbury academic, 2013.

KUNDERA, M. A insustentável leveza do ser. Rio de Janeiro, Nova Fronteia, 1985.

LAROSSA, J. Pedagogia profana: danças, piruetas e mascaradas. Trad. Alfredo VeigaNeto. Belo Horizonte: Autêntica, 2010.

Tremores: escritos sobre experiência. Trad. Cristina Antunes e João Wanderley Geraldi. Belo Horizonte: Autêntica, 2014.

LATOUR, B. Um Prometeu cauteloso? Alguns passos rumo a uma filosofia do design (com especial atenção a Peter Slotedijk). Agitprop: revista brasileira de design, São Paulo, v. 6, n. 58, jul./ago. 2014. Disponível em: http://filosofiadodesign.com/wpcontent/uploads/2014/10/Prometeu-cauteloso.pdf. Acesso em: 11 jul. 2015. LESTIENNE, R. O acaso criador: o poder criativo do acaso. São Paulo: Edusp, 2008. 
LOVE, T. Philosophy of Design: A Meta-theoretical Structure for Design Theory.

Design Studies, 21, 2000, p. 293-313.

. Constructing a coherent cross-disciplinary body of theory about designing and designs: some philosophical issues. Design Studies, 23, 2002, p. 345-361.

MARGOLIN, V. The Politics of the Artificial. Chicago: The University of Chicago Press, 2002.

MARTINS, A. (org.) O mais potente dos afetos: Spinoza e Nietzsche. São Paulo: WMF Martins Fontes, 2009.

MEGGS, P. B. História do design gráfico. São Paulo: Cosac Naify, 2009.

MONTAIGNE, M. Ensaios (3 volumes). São Paulo: Martins Fontes, 2000.

MORIN, E. O paradigma perdido: a natureza humana. Lisboa: Europa-América, 1973.

NIETZSCHE, F. Genealogia da moral: uma polêmica. São Paulo: Companhia das Letras, 1998.

Obras incompletas. São Paulo: Editora Nova Cultural, 1999.

Humano, demasiado humano: um livro para espíritos livres. São Paulo:

Companhia das Letras, 2000.

. A gaia ciência. São Paulo: companhia das Letras, 2001.

Além do bem e do mal: prelúdio a uma filosofia do futuro. São Paulo: Companhia das Letras, 2005.

Crepúsculo dos ídolos: como se filosofa com o martelo. São Paulo: Companhia das Letras, 2006.

O nascimento da tragédia ou helenismo e pessimismo. São Paulo: Companhia das Letras, 2007.

Ecce homo. São Paulo: Companhia das Letras, 2009.

Assim falou Zaratustra. São Paulo: Companhia das Letras, 2011.

ONFRAY, M. Contra-história da filosofia, Volume 3: libertinos barrocos. São Paulo: WMF Martins Fontes, 2009.

A potência de existir: manifesto hedonista. São Paulo: WMF Martins Fontes, 2010.

PAGOTTO-EUZEBIO, M. S. Por que ler os clássicos? In: PAGOTTO-EUZEBIO, M.

S.; ALMEIDA, R. Nós, os antigos: XI Semana de Estudos Clássicos da FEUSP. São

Paulo: Képos, 2014, p. 65-74.

PALMER, R. E. Hermenêutica. Lisboa: Edições 70, 1997.

PAPANEK, V. Design for the Real World: Human ecology and social change. New 
York: Pantheon, 1971.

PERNIOLA, M. A estética do século XX. Lisboa: Editorial Estampa, 1998.

Pensando o ritual: sexualidade, morte, mundo. São Paulo: Studio Nobel, 2000.

PLATÃO. O banquete. Porto Alegre: L\&PM, 2011.

PLUTARCO. Vidas paralelas, volume I. São Paulo: Editora Paumape, 1991.

PORTUGAL, D. P. Design filosófico. Revista Ciência Hoje On-line, caderno

Sobrecultura+, agosto de 2013. Disponível em: http://cienciahoje.uol.com.br/revistach/sobrecultura/2013/08/design-filosofico/. Acesso em 11 jul. 2015.

PESSOA, F. O Eu profundo e os outros Eus. Rio de Janeiro: Nova Fronteira, 1980. O mistério das cousas. In: . Obra Poética. Rio de Janeiro: Ed. Aguilar, 1981, p. $140-141$.

PROUST, M. O tempo redescoberto. Em busca do tempo perdido, volume VII. São Paulo: Editora Globo, 2004.

QUINTAVALLE, A. C. Design: o falso problema das origens. In: Design em aberto: uma antologia. Lisboa: Centro Português de Design, 1993.

RABELO, R. A arte na filosofia madura de Nietzsche. Londrina: Eduel, 2013.

RICOEUR, P. O si mesmo como um outro. Campinas: Papirus, 1990.

Tempo e narrativa. Tomo I. Campinas: Papirus, 1994.

. Tempo e narrativa. Tomo II. Campinas: Papirus, 1995.

. Tempo e narrativa. Tomo III. Campinas: Papirus, 1996.

. A metáfora viva. São Paulo: Edições Loyola, 2000.

. Hermenêutica e ideologias. Petrópolis: Vozes, 2008.

Escritos e conferências II: hermenêutica . São Paulo: Edições Loyola, 2011.

ROCHA, E. Magia e capitalismo: um estudo antropológico da publicidade. São Paulo: Brasiliense, 2010.

ROSSET, C. Lógica do pior. Rio de Janeiro: Espaço e Tempo, 1989.

Le démon de la tautologie suivi de cinq petites pieces morales. Paris: Les

Éditions de Minuit, 1997.

Alegria: a força maior. Rio de Janeiro: Relume-Dumará, 2000.

O princípio de crueldade. Rio de Janeiro, Rocco, 2002.

Le réel: traité de l'idiotie. Paris: Les Éditions de Minuit, 2004.

Fantasmagorías: seguido de lo real, lo imaginario y lo ilusorio. Madrid: Abada, 2006.

SAHM, E. Bergson e Proust: sobre a representação da passagem do tempo. São Paulo: 
Iluminuras, 2011.

SLOTERDIJK, P. Regras para o parque humano: uma resposta à carta de Heidegger sobre o humanismo. São Paulo: Estação Liberdade, 2000.

Esferas III - Espumas: Esferologia Plural. Madrid: Siruela, 2006. . Um filósofo que se intromete: entrevista concedida à Gaby Reucher. Revista Deutsche Welle, ano 2, n. 44, 11 mai. 2011. Versão em português (trad. Alexandre Schossler) disponível em: 〈http://dw.de/p/11BLb〉. Acesso em: 11 jul. 2015. SPINOZA, B. Ética, livro I. Belo Horizonte: Autêntica, 2007. Tratado teológico-político. São Paulo: Martins Fontes, 2008.

TUCÍDIDES. História da Guerra do Peloponeso. São Paulo: Imprensa Oficial do Estado de São Paulo, 2001.

VAIHINGER, H. A filosofia do como se. Chapecó: Argos, 2011.

VALÉRY, P. Introdução ao método de Leonardo da Vinci. São Paulo: Editora 34, 1998.

VATTIMO, G. O fim da modernidade: niilismo e hermenêutica na cultura pósmoderna. São Paulo: Martins Fontes, 1996.

WAGNER, R. A invenção da cultura. São Paulo: Cosac Naify, 2010.

WEINSHEIMER, J. Philosophical Hermeneutics and Literary Theory. New Haven/Londres: Yale University Press, 1991.

WITTGENSTEIN, L. Tractatus logico-philosophicus. São Paulo: Companhia Editora Nacional, 1968.

WONG, W. Princípios de forma e desenho. São Paulo: Martins Fontes, 1998. 